\title{
COMUNIDADES DE PEIXES DE RIACHOS EM FUNÇÃO DA PAISAGEM DA BACIA DO RIO CORUMBATAÍ, ESTADO DE SÃO PAULO
}

\section{Pedro Gerhard}

Tese apresentada à Escola Superior de Agricultura "Luiz de Queiroz", Universidade de São Paulo, para obtenção do título de Doutor em Ecologia de Agroecossistemas.

P I R A C I C A B A

Estado de São Paulo - Brasil

Janeiro - 2005 


\title{
COMUNIDADES DE PEIXES DE RIACHOS EM FUNÇÃO DA PAISAGEM DA BACIA DO RIO CORUMBATAÍ, ESTADO DE SÃO PAULO
}

\section{PEDRO GERHARD}

Biólogo

Orientador: Prof. Dr. LUCIANO MARTINS VERDADE

\begin{abstract}
Tese apresentada à Escola Superior de Agricultura "Luiz de Queiroz", Universidade de São Paulo, para obtenção do título de Doutor em Ecologia de Agroecossistemas.
\end{abstract}

P I R A C I C A B A

Estado de São Paulo - Brasil

Janeiro - 2005 
Dados Internacionais de Catalogação na Publicação (CIP) DIVISÃO DE BIBLIOTECA E DOCUMENTAÇÃO - ESALQ/USP

\section{Gerhard, Pedro}

Comunidades de peixes de riachos em função da paisagem da bacia do Rio Corumbataí, Estado de São Paulo / Pedro Gerhard. - - Piracicaba, 2005.

241 p. : il.

Tese (Doutorado) - - Escola Superior de Agricultura Luiz de Queiroz, 2005. Bibliografia.

1. Bacia hidrográfica 2. Cobertura do solo - Uso 3. Comunidades animais 4. Corumbataí, Rio 5. Ecossistemas agrícolas 6. Paisagem I. Título 
“... [esta terra] nunca poderá ser povoada enquanto lá houver aquela mata feia, baixa, desigual e insalubre..." Edmundo Navarro de Andrade, 1912, p.100 


\section{AGRADECIMENTOS}

Este trabalho jamais poderia ter acontecido sem a presença e a coordenação do Prof. Luciano Verdade. A ele sou grato, em primeiro lugar, pela oportunidade de participar dos primeiros anos do Laboratório de Ecologia Animal, o LEA. Em segundo lugar, por seu apoio às minhas idéias, desde os primórdios do Programa de Pós Graduação Interunidades em Ecologia de Agroecossistemas e do projeto do laboratório junto ao Programa Biota da FAPESP. Em terceiro lugar, por suas idéias a respeito de ecologia, conservação biológica, filosofia e, igualmente, sobre a complexa simplicidade do meio acadêmico (“A geografia é linda, mas a história...”!). Ao Prof. Carlos Alberto Vettorazzi devo muito, pois sua dedicação e competência criaram a base do banco de dados digitais utilizados neste trabalho, sem os quais, nada teria saído das fundações. O Prof. José Eurico Possebon Cyrino ajudou-me nos primeiros anos de estabelecimento na ESALQ e contribuiu com este trabalho com seu sólido conhecimento sobre a biologia de peixes. O Prof. Walter de Paula Lima auxiliou com ótimas referências e excelentes aulas, contribuindo com minha iniciação no campo da hidrologia de microbacias. Agradeço, igualmente, as contribuições do Prof. Naércio de Aquino Menezes, Prof. Edwin Moisés Marcos Ortega, Dra. Lilian Casatti, por auxílios em aspectos fundamentais deste trabalho. Anderson Ferreira, essencial batalhador em todos os momentos do meu doutoramento, auxiliou desde os primeiros dias, participou de mais de $80 \%$ dos (mais de 200) dias do pesado trabalho de campo, foi presente também em

muitas discussões, que se transformaram em planos e projetos. Da mesma forma, o trabalho de campo não teria tido o mesmo brilho sem os incansáveis (Tamaguchi) Henrique Oliveira Sawakuchi, Gabriel (Sapão) Lourenço Brejão, (Prisioneiro) Maurício Tassoni Filho, Bruno (Pastor) Humberto Cordeiro Cavichiolli, (Hadija) Ricardo Augusto 
Brassalotti, Felipe Rossetti (Benito) de Paula, Gustavo Simões (Dexter) Libardi. Junto com Anderson, esta trupe bisonha constituiu a bizarra Equipe Salamandra de Pesca Elétrica. Que vocês possam perdoar este Ogro, mesmo quando lembram dos matacões voando rumo às suas cabeças! Nas muitas estradas da Bacia do Rio Corumbataí fui auxiliado pelo intrépido José Henrique Rocha (Mosquinhas) e pelo moderado Edson Roberto Davanzo, também colega do LEA. Muitos outros vieram e ajudaram nos trabalhos de campo: Leandro (Grude) Ducatti Tremocoldi, Elizandra Chiquito, (Menos Um) Cristiano Gomes Pastor, Maíra (Caiaque) Cotrim, (Xuleta) José Wagner Ribeiro Jr., Élio César Guzzo, Thiago (Salmão) Simon Marques, Carolina Esteves (Ixalá), Júlio César (Frango) Pereira, Jaime Rissi (Passarinho) Passarini, (Beronha) João Vinícius C. Bellodi, (Corn) Fernanda Engels do Nascimento, Vivian Maria de Faria Nasser Vilela (Vilinha), Henrique Sérgio Alves (Ai-Ai-Ai) e Daline (Vinhaça) Vinhal Pereira. Uma grande parte dos frutos apresentados se deve ao casal Kátia Maria Paschoaletto Micchi de Barros Ferraz e Sílvio Frosini de Barros Ferraz, fundamentais na orientação e discussões sobre geoprocessamento e muitas outras questões ligadas ao desenvolvimento geral deste trabalho. Sou grato também pela ajuda intelectual dos colegas Flávio C. T. Lima, Roberta de Oliveira Averna Valente, e do Prof. Flávio A. Bockmann. Agradeço aos colegas do LEA, companheiros e amigos de campo e escritório: especialmente Cláudia Bueno de Campos, André Martins Villaça (também pela trilha sonora), Victor Hugo Cantarelli e Érica P. Haller, mas também Marli Penteado, Graziela D. Miranda, Maristela P. Miranda, Adenilson Cavalcanti, Carla Gheler-Costa, Fábio Comin e (Dona) Nilza. Meus familiares, pais e irmãos, auxiliaram em minha manutenção e estadia em Piracicaba, permitindo que este trabalho se concretizasse. Sou particularmente grato à minha mãe, Sra. Angelina Martha Chopard Gerhard. Agradeço também a muitos proprietários que permitiram nosso acesso aos rios que drenam suas propriedades. Este trabalho teve apoio institucional da FAPESP na forma de uma bolsa de doutoramento (processo número 00/14284-0) e de uma auxílio à Pesquisa vinculado ao Projeto BIOTA (processo número 01/13251-4). Fui auxiliado também pela CAPES e pelo Departamento de Zootecnia (não-ruminantes) da ESALQ. 


\section{SUMÁRIO}

Página

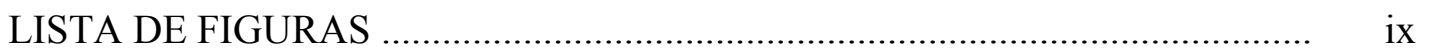

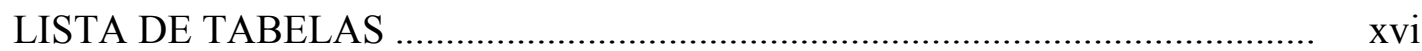

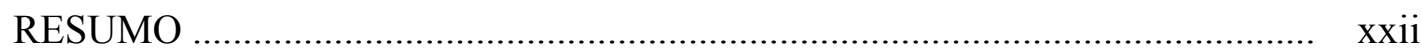

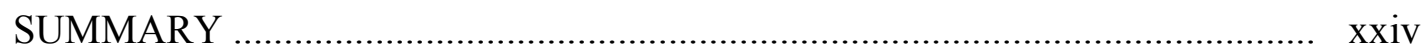

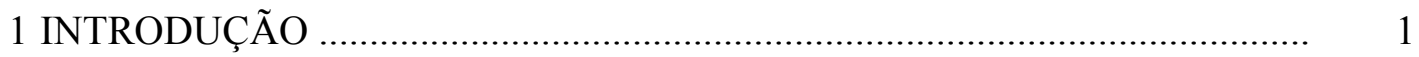

2 REVISÃO DE LITERATURA …............................................................... 4

3 MATERIAL E MÉTODOS ....................................................................... 17

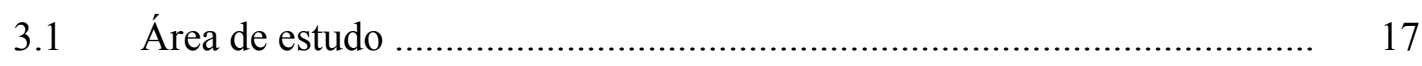

3.1.1 Situação geográfica, política e hidrografia ............................................. 17

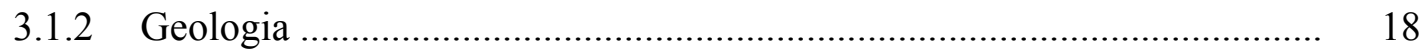

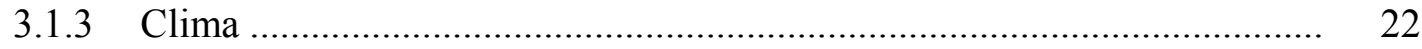

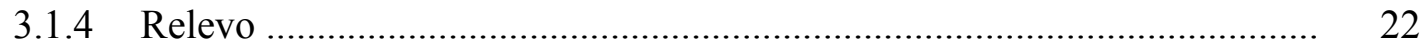

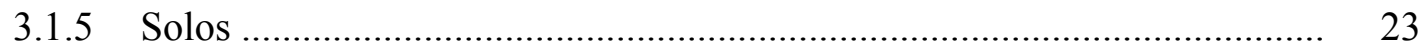

3.1.6 Vegetação nativa ................................................................................ 24

3.1.7 Uso e cobertura do solo recente, histórico e perspectivas .......................... 24

3.2 Seleção das unidades amostrais ............................................................... 29

3.3 Unidades amostrais selecionadas ............................................................. 37

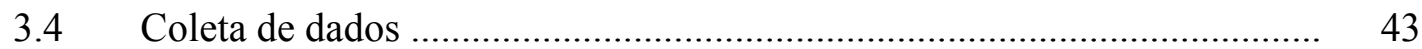

3.4.1 Caracterização das microbacias ................................................................ 44

3.4.2 Caracterização do segmento de amostragem dos peixes .......................... 48

3.4.3 Coleta dos peixes ................................................................................ 58 
3.4.4 Variáveis-resposta _........................................................................ 59

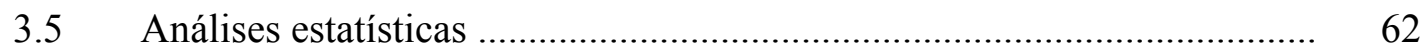

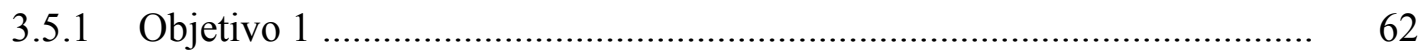

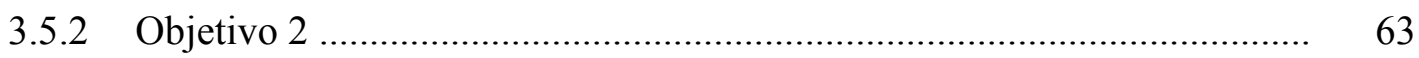

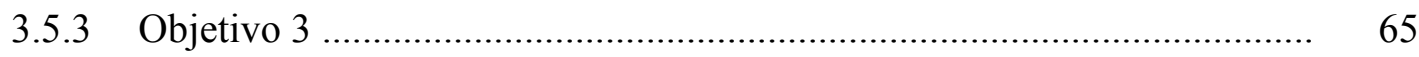

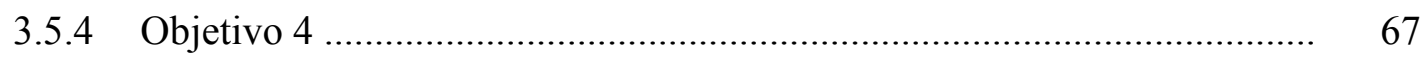

3.5.5 Abrangência e eficácia do levantamento ............................................... 67

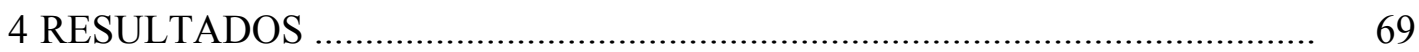

4.1 Composição das amostras ............................................................................. 69

4.1.1 Composição específica …………………................................................... 69

4.1.2 Composição em grupos tróficos ........................................................... 75

4.1.2 Freqüência de ocorrência e abundância do número de indivíduos, biomassa e grupos tróficos - total de amostras ......................................... 77

4.2 Padrões na estrutura das comunidades ..................................................... 84

4.2.1 Número de espécies, indivíduos, grupos tróficos, biomassa e diversidade por amostra

4.2.2 Similaridade entre as comunidades .................................................... 90

4.3 Comunidades de peixes de riachos e habitat ........................................... 97

4.3.1 Uso e cobertura do solo ........................................................................ 97

4.3.2 Abundância e diversidade de comunidades e características do habitat .... 123

4.3.3 Similaridade das comunidades e características do habitat ..................... 128

4.3.4 Relações entre abundância, diversidade e estrutura das comunidades: um

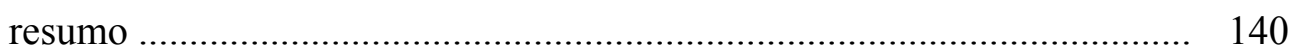

4.4 Padrões geográficos de diversidade de peixes de riachos na Bacia do Rio Corumbataí ............................................................................ 144

4.4.1 Diferenciação das comunidades entre riachos ........................................... 144

4.4.2 Padrões geográficos nas comunidades de peixes ..................................... 146

4.5 Esforço de coleta e curvas de acumulação de espécies ............................ 150

4.6 Efeitos da amostragem nas comunidades .............................................. 153

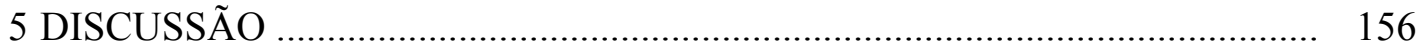


5.1 Composição e estrutura das comunidades ................................................ 156

5.2 Uso e cobertura do solo e comunidades de peixes .................................. 158

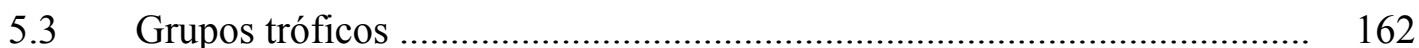

5.4 Estrutura das comunidades ................................................................ 164

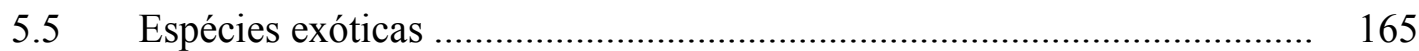

5.6 Diversidade de peixes e fatores ambientais ............................................ 165

5.7 Fragmentação e degradação das florestas nativas e peixes de riacho ........ 170

5.8 Homogeneização de habitat .................................................................... 172

5.9 Comunidades de peixes de riachos como conjuntos de espécies préadaptas aos estresse físico e químico ....................................................... 174

5.10 Uso do solo e hidrologia: perda de cabeceiras ........................................ 176

5.11 Considerações finais ........................................................................... 177

5.12 Perspectivas para estudos futuros ............................................................ 179

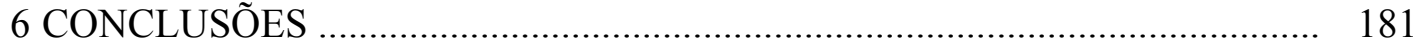

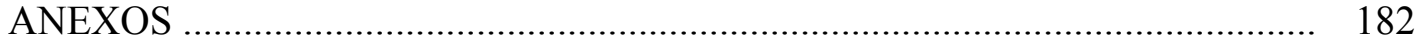

REFERÊNCIAS BIBLIOGRÁFICAS _......................................................... 229 


\section{LISTA DE FIGURAS}

Página

1 Relações entre as atividades antrópicas no ecossistema terrestre e seus efeitos nos ambientes aquáticos, considerando fatores condicionantes

2 Escala espacial do conhecimento corrente sobre peixes lóticos, amplitude provável de escalas de distribuição de eventos críticos do ciclo de vida de muitas espécies, e a escala de estudos necessária para amostrar e predizer atributos de populações e comunidades de peixes em paisagens fluviais. Adaptado de Fausch et al. (2002)

3 Localização da Bacia do Rio Corumbataí, no Brasil e no Estado de São Paulo, e, no detalhe, localização dos centros urbanos e da rede hidrográfica. Coordenadas na projeção UTM, fuso $23 \mathrm{~S}$, datum Córrego Alegre

4 Rede hidrográfica do Rio Corumbataí, Estado de São Paulo. Fonte: CEAPLA (2004, disponível em http://www.rc.unesp.br/igce/ceapla/ biblioteca/download. html)

5 Conformação da geologia da Bacia do Rio Corumbataí, São Paulo. Fonte: CEAPLA (2004, disponível em http://www.rc.unesp.br/igce/ceapla/ biblioteca/download.html)

6 Modelo digital de terreno da Bacia do Rio Corumbataí, destacando aspectos geográficos e políticos. (CEAPLA 2004, disponível em http://www.rc.unesp.br/igce/ceapla/biblioteca/download.html). Coordenadas na projeção UTM, fuso $23 \mathrm{~S}$, datum Córrego Alegre) 
7 Distribuição dos tipos de solo na Bacia do Rio Corumbataí, SP. Fonte: CEAPLA, disponível em http://www.rc.unesp.br/igce/ceapla/biblioteca/ download.html (2004)

8 Distribuição das classes de uso e cobertura do solo na Bacia do Rio Corumbataí. Fonte: Valente \& Vettorazzi (2003)

9 Evolução da cobertura florestal nativa no Estado de São Paulo, com base em Vitor (1975). No mapa do ano 2000, foi representada a localização aproximada da zona do Médio Tietê

10 Diagrama esquemático mostrando o processo de seleção de unidades amostrais

11 Microbacias de cabeceira na Bacia do Rio Corumbataí, destacando-se a categoria de cobertura ou uso do solo dominante em sua área

12 Localização das 60 microbacias amostradas na Bacia do Rio Corumbataí, destacando-se as sub-bacias que a compõem

13 Diagrama esquemático ilustrando como se mede a ordenação dos canais pelo método de Strahler (A) e pelo método de Shreve e a ligação-à-jusante (B). Baseado em Fitzpatrick et al. (1998)

14 Diagrama esquemático ilustrando o método de medida da variável AJ (Tabela 10). É ilustrada uma microbacia qualquer, destacando-se, em seu vertedouro, o ponto de amostragem. Uma circunferência de raio 500 metros foi definida, dentro da qual foi criado um buffer de 30 metros de largura a partir de ambas as margens dos canais ao longo da rede de drenagem contida nesta circunferência

15 Número de espécies pertencentes a cada uma das 14 famílias amostradas em 60 riachos da Bacia do Rio Corumbataí

16 Distribuição de 53 espécies e categorias de peixes em seis grupos tróficos, coletados em riachos da Bacia do Rio Corumbataí, SP

17 Número de ocorrências de 54 espécies e categorias não taxonômicas (cf. Tabela 20) de peixes coletadas em 118 amostras de riachos da Bacia do Rio Corumbataí, SP 
18 Ordenação do número de indivíduos de 54 espécies e categorias não taxonômicas (cf. Tabela 20) de peixes coletadas em 118 amostras de riachos da Bacia do Rio Corumbataí, SP

19 Ordenação de 54 espécies e categorias não taxonômicas (cf. Tabela 20) de peixes por biomassa total coletada em 118 amostras de riachos da Bacia do Rio Corumbataí, SP

20 Distribuições de freqüência de ocorrências do número de espécies (A), número de famílias (B) e número de grupos tróficos (C) em 118 amostras de peixes de riachos da Bacia do Rio Corumbataí, SP

21 Distribuições de freqüência de ocorrência do número de indivíduos (A), e biomassa total (B), de 118 amostras de peixes de riachos da Bacia do Rio Corumbataí, SP

22 Distribuições de freqüência de ocorrência do índice de Shannon (A), índice de eqüitatividade de Shannon (B) e a recíproca do índice de Simpson (C) em 118 amostras de peixes de riachos da Bacia do Rio Corumbataí, SP

23 Resultado da análise de agrupamento de 60 amostras de peixes de riachos (identificadas pelo ID da microbacia no eixo $\mathrm{x}$ ) obtidas nas estações chuvosas de 2003 e 2004, na Bacia do Rio Corumbataí, SP. Medida de dissimilaridade: recíproca do índice de Morisita-Horn. Método de ligação: Ward. Destacou-se o corte em $40 \%$ de dissimilaridade, e os grupos definidos por este corte (I, II, III e IV)

24 Resultado da análise de agrupamento de 58 amostras de peixes de riachos (identificadas pelo ID da microbacia no eixo x) obtidas nas estações secas de 2003 e 2004, na Bacia do Rio Corumbataí, SP. Medida de dissimilaridade: recíproca do índice de Morisita-Horn. Método de ligação: Ward. Destacouse o corte em $40 \%$ de dissimilaridade, e os grupos definidos por este corte (I, II, III, IV e V) 
25 Gráficos box-plot para as amostras das estações chuvosas, ilustrando a distribuição do número de indivíduos (A), índice de Shannon (B) e número de grupos tróficos $(\mathrm{C})$, referente à cobertura do solo dominante na microbacia (variável CD)

26 Gráficos box-plot para as amostras das estações secas, ilustrando a distribuição do número de indivíduos (A), índice de Shannon (B) e número de grupos tróficos $(\mathrm{C})$, referente à cobertura do solo dominante na microbacia (variável CD)

27 Gráficos box-plot para o conjunto de amostras obtidas nas estações chuvosas, ilustrando a distribuição do número de indivíduos (A), índice de Shannon (B) e número de grupos tróficos $(\mathrm{C})$

28 Gráficos box-plot para o conjunto de amostras obtidas nas estações secas, ilustrando a distribuição do número de indivíduos (A), índice de Shannon (B) e número de grupos tróficos (C)

29 Gráficos box-plot para o conjunto de amostras obtidas nas estações chuvosas, ilustrando a distribuição do número de indivíduos (A), índice de Shannon $(\mathrm{B})$ e número de grupos tróficos $(\mathrm{C})$, em relação à variável $\mathrm{DB}$

30 Gráficos box-plot para o conjunto de amostras obtidas nas estações secas, ilustrando a distribuição do número de indivíduos (A), índice de Shannon (B) e número de grupos tróficos $(\mathrm{C})$, em relação à variável $\mathrm{DB}$

31 Ranqueamento (ordenação) de espécies por importância em número de indivíduos de 38 amostras de peixes de riachos em microbacias de predomínio de canaviais, na Bacia do Rio Corumbataí, SP

32 Ranqueamento (ordenação) de espécies por importância em número de indivíduos de 31 amostras de peixes de riachos em microbacias de predomínio de pastagens, na Bacia do Rio Corumbataí, SP

33 Ranqueamento (ordenação) de espécies por importância em número de indivíduos de 22 amostras de peixes de riachos em microbacias de predomínio de matas nativas, na Bacia do Rio Corumbataí, SP 
34 Ranqueamento (ordenação) de espécies por importância em número de indivíduos de 27 amostras de peixes de riachos em microbacias ripárias, na Bacia do Rio Corumbataí, SP

35 Gráfico de análise de correspondência dos grupos de microbacias "pasto", "cana", "nativa" e "ripária", constituídos a partir das listas de abundâncias de 118 amostras de peixes de riachos amostrados entre 2003 e 2004 na Bacia do Rio Corumbataí, SP

36 Distribuição de freqüências percentuais de espécies (A) e indivíduos (B) por grupos tróficos em diferentes categorias de microbacias, separadas pelo predomínio do uso e uso e cobertura do solo na área total (canaviais e matas nativas) ou em sua APP ao longo da rede de drenagem (pastagens e ripárias). Total de 118 amostras

37 Distribuição de freqüências percentuais de espécies (A) e indivíduos (B) por grupos tróficos em diferentes categorias de microbacias, separadas por critérios de uso e cobertura do solo em sua APP ao longo da rede de drenagem (variável DB). Total de 118 amostras

38 Ordenação por escalonamento multidimensional não métrico (NMDS) de 60 amostras de peixes de riachos da Bacia do Rio Corumbataí, SP, obtidas nas estações chuvosas de 2003 e 2004. São ilustrados agrupamentos obtidos por análise de cluster (Figura 23) e correlações das dimensões com variáveis de habitat. Dimensão $1 \times$ Dimensão 2

39 Ordenação por escalonamento multidimensional não métrico (NMDS) de 60 amostras de peixes de riachos da Bacia do Rio Corumbataí, SP, obtidas nas estações chuvosas de 2003 e 2004. São ilustrados agrupamentos obtidos pela análise de agrupamento (Figura 23) e correlações das dimensões com variáveis de habitat. Dimensão $1 \times$ Dimensão 3 
40 Ordenação por escalonamento multidimensional não métrico (NMDS) de 60 amostras de peixes de riachos da Bacia do Rio Corumbataí, SP, obtidas nas estações chuvosas de 2003 e 2004. São ilustrados agrupamentos obtidos por análise de cluster (Figura 23) e correlações das dimensões com variáveis de habitat. Dimensão $2 \times$ Dimensão 3

41 Ordenação por escalonamento multidimensional não métrico (NMDS) de 58 amostras de peixes de riachos da Bacia do Rio Corumbataí, SP, obtidas nas estações secas de 2003 e 2004. São ilustrados agrupamentos obtidos por análise de cluster (Figura 24) e correlações das dimensões com variáveis de habitat. Dimensão $1 \times$ Dimensão 2

42 Ordenação por escalonamento multidimensional não métrico (NMDS) de 58 amostras de peixes de riachos da Bacia do Rio Corumbataí, SP, obtidas nas estações secas de 2003 e 2004. São ilustrados agrupamentos obtidos por análise de cluster (Figura 24) e correlações das dimensões com variáveis de habitat. Dimensão $1 \times$ Dimensão 3

43 Ordenação por escalonamento multidimensional não métrico (NMDS) de 58 amostras de peixes de riachos da Bacia do Rio Corumbataí, SP, obtidas nas estações secas de 2003 e 2004. São ilustrados agrupamentos obtidos por análise de cluster (Figura 24) e correlações das dimensões com variáveis de habitat. Dimensão $2 \times$ Dimensão 3

44 Diagrama esquemático ilustrando relações entre eixos de variação de variáveis descritivas da diversidade e abundância de peixes de riachos (não há proporcionalidade dos eixos), e variáveis ambientais (selecionadas). Detalhes no texto

45 Diagrama esquemático ilustrando a posição relativa dos agrupamentos (I, II, III e IV) obtidos nas análises ilustradas nas Figuras 23 e 24 (atentar para correspondência entre grupos), em função de elevação média e declividade geral das microbacias. As linhas claras indicam curvas de nível eqüidistantes. A linha mais escura indica a drenagem de uma sub-bacia contendo as diferentes categorias ilustradas 
46 Índice de diversidade beta de Whittaker por sub-bacias da Bacia do Rio Corumbataí e sua respectiva porcentagens em matas nativas. O coeficiente de correlação de Pearson é igual a 0,71 , não significante $(p=0,12)$

47 Número de indivíduos por microbacias amostradas na Bacia do Rio Corumbataí, SP, destacando-se as sub-bacias a compõe. Os dados referem-se apenas às coletas efetuadas nas estações chuvosas de 2003 e 2004

48 Índice de diversidade de Shannon por microbacias amostradas na Bacia do Rio Corumbataí, SP, destacando-se as sub-bacias a compõe. Os dados referem-se apenas às coletas efetuadas nas estações chuvosas de 2003 e 2004

49 Número de grupos tróficos por microbacias amostradas na Bacia do Rio Corumbataí, SP, destacando-se as sub-bacias a compõe. Os dados referem-se apenas à totalidade de amostras efetuadas nos anos de 2003 e 2004

50 Curvas de acumulação de espécies em função do número de amostras estimadas para o conjunto de amostras tomada na estações chuvosas (A) e secas (B) de 2003 e 2004, em riachos da bacia do Rio Corumbataí, SP. As curvas seguem as equações: A) $y=44,97\left(1,16-e^{-0,13 x}\right)$, com $r=0,99$ e B) $y$ $=41,31\left(1,17-e^{-0,12 x}\right)$, com $r=0,99$. As setas indicam o ponto da curva correspondente ao esforço amostral empregado

51 Distribuição de freqüência das diferenças do número de espécies de peixes de riachos amostradas entre a segunda e a primeira coleta em uma mesma microbacia ( $n=58$ riachos), na Bacia do Rio Corumbataí. A barra preta indica ausência de diferença. As barras quadriculadas e em cinza escuro indicam diferenças relacionadas à primeira ou segunda coleta ocorridas nas estações secas e chuvosas, respectivamente. A barra pontilhada indica um caso para cada combinação de estações. A barra tracejada indica um caso onde ocorreu uma enchente catastrófica 


\section{LISTA DE TABELAS}

Página

1 Funções da vegetação ripária e implicações no ecossistema aquático em relação aos locais de sua influência

2 Porcentagem de cobertura de diferentes tipos de uso do solo nas sub-bacias do Alto Corumbataí (AC), Passa-Cinco (PC), Médio Corumbataí (MC), Ribeirão Claro (RC) e Baixo Corumbataí $\mathrm{BC}$ ), pertencentes à Bacia do Rio Corumbataí, Estado de São Paulo. Dados a partir do mapa do uso e cobertura do solo de 9/5/2001

3 Áreas (em hectares) das seis sub-bacias da Bacia do Rio Corumbataí consideradas no presente projeto, derivadas de informações obtidas junto ao Projeto Corumbataí (2001)

4 Número de microbacias de cabeceiras criadas pelos softwares SWAT e ArcView na Bacia do Rio Corumbataí, separadas pelo tipo de cobertura ou uso do solo predominante

5 Número de microbacias por sub-bacias da Bacia do Rio Corumbataí e por classes de uso ou cobertura do solo

6 Microbacias na Bacia do Rio Corumbataí, Estado de São Paulo com predomínio de canaviais. ID como discutido no texto. Sub-bacias: $c a=$ Rio da Cabeça, $\mathrm{rc}=$ Ribeirão Claro e bc $=$ Baixo Corumbataí. Coordenadas em UTM, fuso 23 S, Datum Córrego Alegre 
7 Microbacias na Bacia do Rio Corumbataí, Estado de São Paulo com predomínio de matas nativas. ID como discutido no texto. Sub-bacias: ac $=$ Alto Corumbataí, $\mathrm{pc}=$ Rio Passa-Cinco, $\mathrm{rc}=$ Ribeirão Claro e $\mathrm{bc}=$ Baixo Corumbataí. Coordenadas em UTM, fuso $23 \mathrm{~S}$, Datum Córrego Alegre

8 Microbacias na Bacia do Rio Corumbataí, Estado de São Paulo com predomínio de pastagens. ID como discutido no texto. Sub-bacias: ac $=$ Alto Corumbataí, $\mathrm{mc}=$ Médio Corumbataí, $\mathrm{ca}=$ Ribeirão da Cabeça, $\mathrm{pc}=$ Rio Passa-Cinco, $\mathrm{rc}=$ Ribeirão Claro e bc = Baixo Corumbataí. Coordenadas em UTM, fuso 23 S, Datum Córrego Alegre

9 Microbacias na Bacia do Rio Corumbataí, Estado de São Paulo denominadas ripárias. ID como discutido no texto. Sub-bacias: $a c=$ Alto Corumbataí, $\mathrm{mc}=$ Médio Corumbataí, $c a=$ Ribeirão da Cabeça, e $\mathrm{pc}=$ Rio Passa-Cinco. Coordenadas em UTM, fuso 23 S, Datum Córrego Alegre

10 Variáveis utilizadas na descrição das microbacias

11 Variáveis de parâmetros físicos e químicos da água amostras no momento de captura dos peixes. Procedimentos de análise segundo American Public Health Association (1975), exceto quanto ao oxigênio, saturação de $\mathrm{O}_{2}$ e T ...

12 Categorias ou classes de substrato e seus tamanhos (maior eixo), em milímetros. Simplificado da escala de Wentworth, de acordo com Cummins (1962)

13 Categorias de velocidade da água na superfície, modificadas de Bisson \& Montgomery (1996)

14 Tipos de unidades de habitat, adaptado de Fitzpatrick et al. (1998)

15 Variáveis derivadas dos métodos de mensuração de variáveis do canal, barrancas e entorno

16 Variáveis obtidas das amostras de peixes de riachos da Bacia do Rio Corumbataí, Estado de São Paulo

17 Grupos tróficos e sua diagnose, conforme Sawakuchi et al. 
18 Códigos de espécies e categorias taxonômicas utilizadas ao longo deste trabalho

19 Grupos tróficos de 53 espécies e categorias de peixes de riachos da Bacia do Rio Corumbataí

20 Número de indivíduos totais $\left(n_{i}\right)$, porcentagem do total $(n \%)$, biomassa de indivíduos totais $\left(m_{i}\right)$ e porcentagem do total $\left(m_{\%}\right)$ de 53 espécies e categorias de peixes coletados em 118 amostras de riachos da Bacia do Rio Corumbataí*

21 Ranqueamento em ordem decrescente das dez espécies mais importantes em termos de número de ocorrências, número de indivíduos e biomassa total em um total de 118 amostras de riachos da Bacia do Rio Corumbataí, SP

22 Média, desvio-padrão, valores mínimos e máximos de descritores de diversidade e abundância de 118 amostras de peixes de riachos da Bacia do Rio Corumbataí, SP

23 Espécies exclusivas, constantes e dominantes em cada um dos grupos contidos na Figura 23. Os grupos referem-se às 60 amostras obtidas nas estações chuvosas de 2003 e 2004

24 Espécies exclusivas, constantes e dominantes em cada um dos grupos contidos na Figura 24. Os grupos referem-se às 58 amostras obtidas nas estações secas de 2003 e 2004

25 Concordância entre os grupos obtidos através da análise de agrupamento realiza para o conjuntos de amostras obtidas nas estações chuvosas secas. As amostras que não encontram pares entre os grupos foram destacadas em negrito. É apresentado o número total de amostras (\# amostras), o número de amostras em comum entre os grupos (comum) e a porcentagem de comuns em relação ao total ( \% comum)

26 Número total de amostras, média e desvio-padrão do número de indivíduos $(N)$, índice de Shannon $\left(H^{\prime}\right)$ e número de grupos tróficos $(G T)$ dos grupos obtidos nas análises de agrupamento realizadas para dois conjuntos de amostras de peixes de riachos (chuva e seca) na Bacia do Rio Corumbataí, SP 
27 Número de amostras (\#), média e desvio padrão do número de indivíduos $(N)$, índice de diversidade de Shannon $\left(H^{\prime}\right)$ e número de grupos tróficos $(G T)$ por amostra de peixes de riachos da Bacia do Rio Corumbataí, SP, tomadas nas estações chuvosas e secas dos anos 2003 e 2004

28 Resumo das estatísticas da análise de variância (tipo 1) para 46 e 45 amostras de peixes de riachos da Bacia do Rio Corumbataí, SP, coletadas nas estações chuvosas e secas de 2003 e 2004, respectivamente

29 Número de amostras (\#), média e desvio padrão do número de indivíduos $(N)$, do índice de diversidade de Shannon $\left(H^{\prime}\right)$, e número de grupos tróficos $(G T)$ por amostra de peixes de riachos da Bacia do Rio Corumbataí, SP, tomadas na estações chuvosas e secas dos anos 2003 e 2004

30 Resumo das estatísticas de análise do teste $t$ para comparação de descritores de riqueza e diversidade entre microbacias de pastagens e ripárias da Bacia do Rio Corumbataí, SP, amostrados durante as estações chuvosas e secas de 2003 e 2004

31 Número de amostras (\#), média e desvio padrão do número de indivíduos $(N)$, índice de diversidade de Shannon ( $\left.H^{\prime}\right)$ e número de grupos tróficos $(G T)$ por amostra de peixes de riachos da Bacia do Rio Corumbataí, SP, tomadas nas estações chuvosas e secas dos anos 2003 e 2004, em relação à cobertura dominante na zona ripária, variável DB

32 Resumo das estatísticas da análise de variância (tipo 1) para 60 e 58 amostras de peixes de riachos da Bacia do Rio Corumbataí, SP, coletadas nas estações chuvosas e secas de 2003 e 2004, respectivamente, em relação à cobertura dominante na zona ripária, variável DB

33 Ranqueamento das dez espécies mais importantes por conjunto de amostras de peixes de riachos de microbacias de predomínio de pastagens, canaviais, matas nativas e ripárias. Amostras obtidas da Bacia do Rio Corumbataí, SP ...

34 Coeficientes de inclinação das retas (b) obtidas pela transformação logarítmica das curvas de ordenação por abundância de espécies, mostradas nas Figuras 31 a 34 
35 Número absoluto e porcentagem (entre parênteses) de amostras dos agrupamentos definidos na Figura 23 por classes de uso e cobertura do solo em microbacias da Bacia do Rio Corumbataí, SP

36 Número absoluto e porcentagem (entre parênteses) de amostras dos agrupamentos definidos na Figura 24 por classes de uso e cobertura do solo em microbacias da Bacia do Rio Corumbataí, SP

37 Lista de variáveis descritivas de habitat que apresentaram correlações ( $r$ de Pearson) ou cuja análise de variância (ANOVA tipo I) categorizada pela variável (em itálico) foi significativa $(\alpha=0,05)$. Abreviações das variáveis descritivas como nas Tabelas 10, 11 e 15. Detalhes nos Anexos H e I .

38 Resumo do modelo de regressão múltipla sobre a variável H', considerando como preditores uma constante e oito, a partir de 60 amostras de peixes de riachos da Bacia do Rio Corumbataí, tomadas nas estações chuvosas de 2003 e 2004

39 Resultados da Análise de Variância (ANOVA) sobre o modelo de regressão resumido na Tabela 38

40 Valores dos coeficientes do modelo de regressão descrito na Tabela 38, nãoestandardizados, estandardizados $(ß)$ e respectivos valores de $t$ e sua probabilidade associada

41 Resumo do modelo de regressão múltipla sobre a variável H', considerando como preditores uma constante as variáveis descritivas $\mathrm{CI}$, SO e VP, a partir de 58 amostras de peixes de riachos da Bacia do Rio Corumbataí, tomadas nas estiagens de 2003 e 2004

42 Resultados da Análise de Variância (ANOVA) sobre o modelo de regressão resumido na Tabela 41

43 Valores dos coeficientes do modelo de regressão descrito na Tabela 41, nãoestandardizados, estandardizados (ß) e respectivos valores de $t$ e sua probabilidade associada 
44 Resumo das variáveis descritivas do meio ambiente estatisticamente significativas (ANOVA tipo I, $\alpha=0,05$ ) em relação aos agrupamentos obtidos através da análise de cluster nas estações chuvosas e secas de 2003 e 2004 (Figuras 23 e 24). Detalhes no Anexo J

45 Comparação de variáveis ambientais significativamente correlacionadas com descritores de abundância $(N)$, diversidade $\left(H^{\prime}\right.$ e $\left.G T\right)$ e similaridade de comunidades de peixes de riachos da Bacia do Rio Corumbataí

46 Número de rios amostrados $\left(n_{\text {rios }}\right)$, número de espécies acumuladas $\left(S_{\text {total }}\right)$, número médio de espécies $\left(S_{\text {médio }}\right)$ e índice de diversidade beta de Whittaker $\left(B_{W}\right)$, relativos a comunidades de peixes da Bacia do Rio Corumbataí, SP .......

47 Número de espécies $(S)$ total e acumulado, e de indivíduos $(N)$ de peixes amostrados em quatro campanhas de coletas na Bacia do Rio Corumbataí, Estado de São Paulo

48 Número de espécies observadas $\left(S_{o b s}\right)$ e estimadores de riqueza total de espécies pelo método de Jacknife, Bootstrap e valor máximo estimado a partir da função assintótica conforme as equações da Figura $49\left(S_{a}\right)$. São mostrados os valores percentuais de espécies obtidas em relação a estes estimadores (\% $S_{\text {obs }}$ )

49 Resultados dos testes $t$-pareados sobre as variáveis-resposta $N, H^{\prime}$ e $G T$. Cada análise levou em consideração um medidas tomadas na primeira (anterior) e segunda (posterior) coleta em cada microbacia, constituindo, assim, 58 pares de amostras 


\section{COMUNIDADES DE PEIXES DE RIACHOS EM FUNÇÃO DA PAISAGEM DA BACIA DO RIO PIRACICABA, ESTADO DE SÃO PAULO}

Autor: PEDRO GERHARD

Orientador: Prof. Dr. LUCIANO MARTINS VERDADE

\section{RESUMO}

A bacia do Rio Corumbataí é estratégica para o abastecimento de água para cidades como Rio Claro e Piracicaba e representa um agroecossistema característico da região Sudeste do Brasil. Foi delineado um estudo para conhecer as relações entre a diversidade de peixes de riachos e o uso e a cobertura do solo. Foi avaliada a hipótese nula: a abundância total em indivíduos, a diversidade (índice de Shannon, $H^{\prime}$ ) e o número de grupos tróficos $(G T)$ não é influenciada pelo uso e cobertura do solo. A Bacia do Rio Corumbataí foi dividida em microbacias da ordem de 200 hectares. Estas foram categorizadas quanto ao predomínio (cobertura dominante, $\mathrm{CD}$ ) de canaviais, pastagens e matas nativas. As microbacias de pastagens foram separada em dois grupos quanto à porcentagem de matas nativas em sua área de preservação permanente ao longo dos canais (APP), constituindo quatro grupos de microbacias. Foram escolhidas 60 microbacias alocadas nestes grupos. Um banco de dados sobre a Bacia foi usado para caracterizar as microbacias quanto ao uso e cobertura do solo, aspectos do relevo e rede de drenagem, tipo de solo e geologia. No campo, foram selecionados trechos de riacho 
para a amostragem de peixes, que foram caracterizados quanto às suas características do entorno e do canal e quanto à parâmetros físicos e químicos da água. Cada trecho foi amostrado duas vezes: uma na estação chuvosa, uma na estação seca, ao longo dos anos de 2003 e 2004. Análises de variância e de médias sobre os descritores de abundância e diversidade agrupados por $\mathrm{CD}$ indicaram diferenças significativas entre os grupos definidos. Maior diversidade ( $H^{\prime}$ e GT) foi encontrada em microbacias de predomínios de pastagens e menor em microbacias de matas nativas. As diferenças são mais claras quando ocorrem matas nativas ou pastagens nas APPs das microbacias. Microbacias de pastagens apresentaram o grupo dos detritívoro-iliófagos e menor número de insetívoros, o que pode ser mediado pelo relevo em que ocorrem e pelo aumento da produtividade devido à ausência de mata na zona ripária. Uma análise de agrupamento revelou a existência de quatro a cinco comunidades mais similares entre si. Análises de correlação e escalonamento multidimensional não-métrico revelaram que a maior parte da diferenciação entre estes agrupamentos é devida ao relevo e a aspectos ambientais que covariam com este fator. O próprio uso do solo depende do relevo, e uma associação entre microbacias com maior porcentagem de matas nativas em sua área, ou em sua APP, e um agrupamento característico de espécies pode ser detectado. Outro agrupamento está associado a regiões de baixa declividade e altitude, onde ocorrem as microbacias de pastagens. As diferenças encontradas refletem, provavelmente,a degradação e a fragmentação florestal, a retração de nascentes e a homogeneização de habitat entre riachos e ribeirões, nas áreas planas. As comunidades de peixes da Bacia do Rio Corumbataí apresentam modificações que podem ser atribuídas ao padrão de uso do solo, dependente do relevo. Este padrão gera processos distintos de degradação do meio ambiente que afeta os agrupamentos característicos de espécies de modo diferenciado. 


\section{STREAM FISH COMMUNITIES AND ITS RELATIONS TO LAND USE AND LAND COVER IN THE CORUMBATAÍ RIVER BASIN, STATE OF SÃO PAULO, BRAZIL}

Author: PEDRO GERHARD

Adviser: Prof. Dr. LUCIANO MARTINS VERDADE

\section{SUMMARY}

The Rio Corumbataí watershed is a strategic area for water supply to large urban centers such as Rio Claro and Piracicaba. It is also a typical agroecosystem of Southeastern Brazil. This study was performed in order to understand stream fish diversity and land-use-land-cover (LULC) relationships. The general null hypothesis states that LULC does not relate to fish abundance, diversity (Shannon diversity index, $\left.H^{\prime}\right)$ and number of fish trophic groups (GT). SWAT and ArcView softwares were used to split Rio Corumbataí watershed into small (near 200 hectares) catchments. These small catchments were further classified according to its dominant land cover (CD), as either sugar cane plantations, pastures or native forest remnants. A further step on this classification divided pasture-dominated catchments into two groups differing on the amount of native forest remnants along its riparian zone (30 meters wide buffer strips, APP). Thus, four groups of catchments were recognized. Sixty of these catchments were assigned to these groups. A digital database on the Rio Corumbataí watershed was used to perform a thorough description of each of these small catchments in terms of LULC, soil, geology, terrain aspect and hydrology. In the field, 150 meters long reaches on the 
main catchment stream were selected for sampling fish, by means of electrofishing under a depletion procedure. Stream reach and channel morphology were characterized by using standard sampling protocols, and stream water samples were collected to study physicochemical parameters. Stream reaches were sampled twice, during the rainy and the dry seasons of 2003 and 2004. Stream fish abundance and diversity data were analyzed by means of standard analysis of means and variances, using $\mathrm{CD}$ as a categorical predictor. Results showed significant differences among groups. Higher diversity ( $H^{\prime}$ and $\left.G T\right)$ was found between pasture-dominated and forested catchments. Differences seemed to be clearer when the distinction between forested and non-forested riparian zones were taken into account on this comparisons. Pasture-dominated catchments were the only group exhibiting the detritivore-iliophagous group and insectivores were always less abundant in these areas. These differences can be ascribed both to channel geomorphic characteristics and increased primary productivity mediated by the absence of riparian forests. A cluster analysis on the similarity among samples indicated the existence of four to five discrete species assemblages. Correlation analysis and non-metric multidimensional scaling on more than 60 habitat variables revealed that most of the assemblage differences can be related to large scale terrain aspects and many correlated habitat features. Land use itself is dependent on terrain characteristics, and there is a clear association among an upland species assemblage and forested dominated catchments and a lowland species assemblages and grassland areas. Results were discussed regarding the hypothesis of forest degradation/fragmentation, downstream springs migration and habitat homogenization between lowland stream reaches and riverine downstream stretches. Stream fish communities in the Rio Corumbataí watershed shows differences that can be related to LULC patterns, which is highly dependent on terrain characteristics. These patterns determine different impacts under the stream network which, in turn, affects upland and lowland species assemblages differently. 


\section{INTRODUÇÃO}

Rios e riachos são componentes importantes das paisagens continentais e representam cerca de um centésimo da superfície terrestre e apenas um décimo de milionésimo da quantidade de água presente no globo (Hynes, 1972). Estas pequenas frações trazem uma falsa noção da importância que estes habitats têm na conexão das massas continentais aos oceanos. Se por um lado estes ambientes representam apenas uma pequena área da superfície terrestre, por outro favoreceram o surgimento de uma infinidade de espécies, devido a características como o isolamento geográfico entre bacias e a heterogeneidade ambiental dos rios.

Atualmente, é reconhecida a fragilidade das espécies que habitam os rios, o que se deve principalmente à importância da relação entre estes e a vegetação ripária, a qual age como barreira protetora contra efeitos deletérios a estes ecossistemas (Naiman et al., 1992; Malanson, 1993). Os impactos causados pelas atividades humanas sobre os corpos de água são diretos e indiretos, e determinam desde modificações na composição de espécies até a eliminação completa de algumas ou todas as espécies da ictiofauna local (Burcham, 1988; Menezes et al., 1990; Moyle, 1994).

A Bacia do Rio Corumbataí, situada junto a importantes centros urbanos, agrícolas, tecnológicos e científicos do sudeste do Brasil, vem sendo degradada há mais de um século, seja pelo uso e ocupação inadequados do solo, seja pela retirada excessiva da água para consumo humano e agrícola (Projeto Corumbataí, 2001). O conhecimento das interações entre a diversidade e a degradação ambiental originada pelas atividades agropecuárias é ainda largamente desconhecida, especialmente sobre peixes de pequenas bacias hidrográficas brasileiras. Por outro lado, peixes vêm sendo considerados como 
excelentes indicadores de degradação ambiental, podendo constituir índices da saúde ambiental de riachos, por exemplo (Karr \& Chu, 1999).

Considerando este contexto, foi delineado um plano de pesquisa com o objetivo central de estudar as relações entre a abundância, a diversidade e a estrutura de comunidades de peixes de riachos com as principais categorias de uso e cobertura do solo na Bacia do Corumbataí, que são as pastagens, os canaviais e os remanescentes de formações florestais nativas. Respostas específicas de algumas espécies às alterações ambientais não foram tratadas no presente.

Foi considerada como hipótese geral neste trabalho que a diversidade de peixes de riachos é influenciada pelo tipo de cobertura e uso do solo predominante da microbacia onde este corpo de água ocorre. Assim, a hipótese nula deste estudo é:

$$
H_{0}: K_{f n}=K_{c a}=K_{p a}
$$

Ou seja, a hipótese é de que um descritor qualquer de diversidade de uma comunidade de peixes, $K$, não difere entre microbacias com predomínio de florestas nativas $(f n)$, canaviais $(c a)$ ou pastagens $(p a)$.

Como estratégia geral para verificar esta hipótese e alguns de seus desdobramentos possíveis, foram traçados os objetivos específicos listados a seguir:

1. Detectar a existência de padrões na estrutura das comunidades de peixes amostradas;

2. Verificar se existe relação entre abundância, a diversidade e a estrutura de comunidades de peixes de riachos e o uso e cobertura do solo predominante nas microbacias, isto é, entre canaviais, pastagens e matas nativas;

3. Detectar as fontes de variação na estrutura das comunidades, provenientes de:

- $\quad$ aspectos geomorfológicos da microbacia;

- características do entorno do canal, como uso e cobertura do solo;

- características físicas e químicas da água; e

- $\quad$ aspectos físicos do canal no trecho de amostragem. 
4. Entender como se distribui a diversidade de peixes de riachos no agroecossistema da Bacia do Rio Corumbataí, com área total de 170.000 hectares, especialmente em termos de suas sub-bacias. 


\section{REVISÃO DE LITERATURA}

Rios de cabeceiras são fortemente influenciados pelo meio terrestre devido ao baixo quociente entre a área do canal e sua respectiva área de drenagem (Karr \& Schlosser, 1978). Assim, por exemplo, eventos de precipitação individuais podem ter conseqüências catastróficas na estruturação dos ecossistemas lóticos e seu adjacente, o ripário. Isto indica claramente a forte relação que existe entre o ambiente terrestre e o aquático, de modo que intervenções de natureza antrópica no primeiro acarretarão em fortes efeitos no segundo. Esta ligação é que torna os riachos e rios indicadores apropriados da saúde ambiental de uma bacia hidrográfica (Forman, 1995; Naiman \& Bilby, 1998).

As relações entre um corpo de água lótico e o vale que o acompanha foram explicitadas primeiramente no trabalho de Hynes (1975). Karr \& Schlosser (1977, 1978) identificaram diversos problemas relacionados à retirada total ou parcial da vegetação (floresta) ripária, relacionando estes problemas à diversidade de peixes de riachos, por exemplo. Este corpo de conhecimento foi, por sua vez, fortemente influenciado pela publicação de dois trabalhos, o de Hynes (1972), que sumariza todo conhecimento sobre a ecologia de rios disponível até aquele momento, e o livro de Leopold et al. (1964), tratando da geomorfologia do ponto de vista dos canais fluviais.

Os trabalhos que seguem, no que diz respeito às interações entre uso da terra $\mathrm{e}$ comunidades de peixes de riachos podem ser relacionados ao diagrama da Figura 1, que sumariza os principais tipos de atividades antrópicas em uma microbacia e seus respectivos efeitos no ecossistema aquático. Foram considerados como fatores mediadores (condicionadores) destas interações o clima e a formação geológica local que, por sua vez, interagem determinando os tipos de solos, o relevo e a vegetação 
natural da região. Cada uma das atividades listadas no diagrama pode ocorrer tanto nas encostas como na zona ripária, o que pode ter efeitos mais ou menos fortes no sistema aquático. Os efeitos explicitados, neste caso, são todos à jusante, isto é, são passíveis de serem mensurados em um ponto da microbacia em relação à área de drenagem à montante do local de estudo.

\section{Sistema terrestre: bacia hidrográfica}

Atividades humanas:

Urbanização

Desmatamento

Agricultura

Fatores

Pecuária (pastejo)

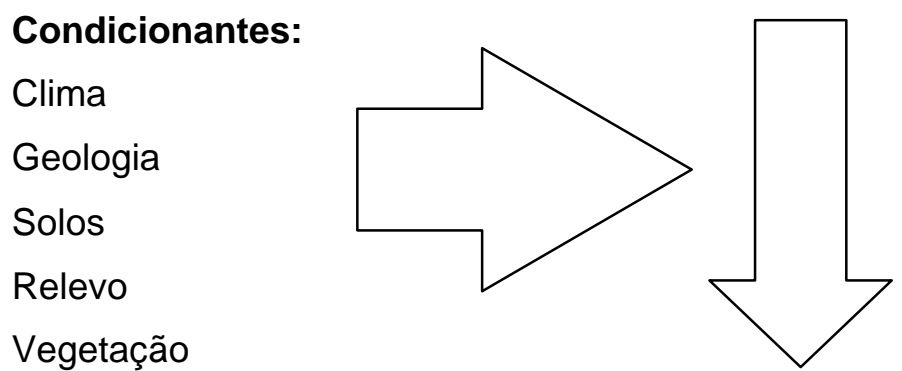

Sistema aquático: rio ou riacho

Efeitos das atividades antrópicas:

Regime de vazão

Morfologia dos canais

Qualidade da água

Fontes de energia

Interações bióticas

Diversidade biológica

Figura 1 - Relações entre as atividades antrópicas no ecossistema terrestre e seus efeitos nos ambientes aquáticos, considerando fatores condicionantes 
Matthews (1998) cita que é o trabalho de Hynes (1975) que desloca a atenção dos pesquisadores da ecologia dos peixes fluviais de uma visão "longitudinal", para uma visão lateral, ou melhor, da paisagem. Para Ward (1989), por exemplo, os ecossistemas lóticos devem ser estudados e analisados em quatro dimensões (longitudinal, lateral, vertical e temporal). Trata-se de uma consideração em oposição à visão anterior, onde a escala longitudinal era enfatizada, como no clássico esquema do rio como um contínuo, de Vannote et al. (1980).

A dimensão lateral nem sempre têm sido mensurada em variáveis quantitativas. Ainda assim, diversos trabalhos sobre a ecologia (de peixes) de riachos tratam das relações terra-água sem que o termo "paisagem" seja explicitado. Podem ser citados, por exemplo, trabalhos sobre a disponibilidade de insetos como alimento (Lotrich, 1973; Edwards \& Huryn, 1996); estrutura trófica e dieta das espécies (Burcham, 1988; Ferreira, 2004); estrutura das comunidades (Brown, 2000); entrada de matéria orgânica alóctone e produtividade do sistema (Bilby \& Bisson, 1992); disponibilidade e transporte de sedimentos das encostas para os rios (Vitousek, 1977; Randall et al., 1995), incluindo os efeitos da sedimentação nos riachos (Beschta, 1978; Berkman \& Rabeni, 1987; Waters, 1995); fontes e qualidade da água relacionada (Karr \& Schlosser, 1977, 1978; Matthews et al., 1992); influências da geologia e geomorfologia (Lonzarich et al., 1998; Lonzarich et al., 2000; Reid et al., 2004; Tipton et al., 2004); aspectos da hidrologia (Moyle \& Williams, 1990; Nagasaka \& Nakamura, 1999) e demais alterações no ciclo hidrológico, como retirada de água para irrigação (Cross \& Moss, 1987). A compreensão da distribuição e da abundância de peixes em uma escala de décadas frente às mudanças no uso da terra também foram estudadas por Simon et al. (1995), Fitzgerald et al. (1998) e McCleary \& Bambrick (2004).

Outra vertente de trabalhos tratando da interação entre os ecossistemas terrestres e aquáticos merece destaque. Eles tratam da importância da vegetação ripária na manutenção da integridade biótica do sistema lótico, detalhada em Lowrance et al. (1984), Gregory et al. (1991), Kolasa \& Zalewski (1995) e Klapproth \& Johnson (2000). A Tabela 1 sumariza as funções da vegetação ripária (como formações florestais) em relação aos ecossistemas aquáticos. 
Tabela 1. Funções da vegetação ripária e implicações no ecossistema aquático em relação aos locais de sua influência

\begin{tabular}{lll}
\hline Locais & Componentes & Funções \\
\hline $\begin{array}{l}\text { Acima do solo e } \\
\text { acima do canal }\end{array}$ & Copa e galhos & $\begin{array}{l}\text { Sombreamento controla temperatura } \\
\text { e produtividade primária. Fonte de } \\
\text { detritos vegetais grandes e pequenos. } \\
\text { Refúgio de fauna. }\end{array}$ \\
Canal & $\begin{array}{l}\text { Troncos de grande porte derivados da } \\
\text { vegetação ripária }\end{array}$ & $\begin{array}{l}\text { Controla o caminho da água e } \\
\text { sedimento. Molda os habitats: poços, } \\
\text { corredeiras, cobertura. }\end{array}$ \\
& Raízes & $\begin{array}{l}\text { Aumentam estabilidade das } \\
\text { barrancas. Criam barrancas como } \\
\text { abrigos. Retiram nutrientes da água } \\
\text { do riacho e do solo. }\end{array}$ \\
& Galhos e vegetação rasteira & $\begin{array}{l}\text { Retardam movimento de sedimento, } \\
\text { água e detritos orgânicos flutuantes } \\
\text { durante picos de vazão (ocasionados } \\
\text { por chuvas intensas e pontuais). }\end{array}$ \\
\hline
\end{tabular}

Fonte: Swanson et al. (citado por Naiman, 1992)

Foram documentadas relações intrincadas entre representantes dos ecossistemas fluvial e de mata ciliar, como entre peixes caraciformes frugívoros e árvores frutíferas da região amazônica (Goulding, 1980). Bisson et al. (1992) mostram que riachos percorrendo trechos onde a mata ripária foi retirada apresentam redução na diversidade de espécies de salmonídeos, mesmo considerando riachos ocorrendo em quatro tipos distintos de embasamento geológico. Os autores citam que há uma forte relação entre diversidade de salmonídeos e a quantidade de poços formados pela erosão causada por grandes troncos caídos, oriundos da mata ripária. Barton et al. (1985) relacionam retiradas da vegetação ao aumento das temperaturas máximas de verão em riachos da região temperada do Canadá, mostrando que é nestes sistemas onde ocorre a maior redução dos estoques de trutas. Resultado similar foi reportado para riachos do norte do Japão, onde populações de salmão masu são obrigadas a migrar para trechos mais à 
montante em sistema de rios onde há histórico de progressiva retirada de matas ciliares (Nagasaka \& Nakamura, 1999). Na mesma linha, McCleary et al. (2004) mostraram que a retirada da mata ripária traz alterações significativas em características de habitat, mas que podem levar até 20 anos para se tornarem perceptíveis, com efeitos negativos na manutenção de populações da truta-arco-íris, Oncorhynchus mykiss. A retirada da vegetação ciliar em regiões onde ocorrem florestas também pode trazer alterações significativas na produtividade dos sistemas lóticos, com elevação da densidade e da produtividade de salmonídeos em áreas recém-desmatadas (Murphy et al., 1981). Por outro lado, Rinne (1990) afirma que os usos antrópicos do corredor ripário podem ser detectados tanto por variáveis físicas e químicas, como radiação solar, qualidade de temperatura da água e sedimentos finos, quanto variáveis bióticas, como a estrutura da vegetação ripária e a estrutura das comunidades de peixes e macroinvertebrados. Há que se ressaltar que, a despeito de todos os aparentes benefícios que uma faixa de mata de cerca de 10 a 30 metros ao redor dos rios pode trazer, eventualmente estes "filtros" podem deixar de ser efetivos se a magnitude de distúrbios suplantar sua capacidade retentora de sedimentos ou de ciclagem de nutrientes Osborne \& Kovacic (1993).

Os trabalhos acima, entretanto, tratam de interações entre a faixa de terreno mais próxima aos corpos de água onde foram realizados os estudos, entre $10 \mathrm{~m}$ e $500 \mathrm{~m}$ de largura a partir das margens. Entretanto, a dimensão longitudinal também deve ser levada em consideração, pois guarda relação direta com aumento de temperatura (Barton et al., 1985), e ciclagem de matéria orgânica (Johnson \& Covich, 1997) em um dado ponto dentro da rede de drenagem.

Até o presente, foram apresentados trabalhos que estudaram a relação entre alterações no uso e cobertura do solo e efeitos sobre os peixes de riachos. Estes trabalhos focaram a dimensão longitudinal ou lateral do ecossistema lótico, mas não do uso e cobertura do solo nas encostas do vale, isto é, focando a bacia hidrográfica como unidade de estudo. Poucos foram os trabalhos com este objetivo ou com esta precisão, o que é um possível efeito do recente desenvolvimento das técnicas de sensoriamento remoto orbital e facilidades associadas aos Sistemas de Informações Geográficas (SIG), que possibilita, por exemplo, a delimitação dos divisores topográficos das microbacias. 
Roth et al. (1996) analisaram a integridade biótica e a qualidade de habitat de riachos através de SIG em diferentes escalas, relacionando estas com a atividade agrícola. O objetivo central deste trabalho era o de determinar se o uso do solo é um bom preditor da integridade de ecossistemas lóticos, medida através de atributos das comunidades de peixes de riachos. Os autores concluíram que os índices de integridade biótica são relacionados negativamente com a extensão da área agricultada na microbacia e positivamente com a extensão de florestas e várzeas. As correlações foram mais fortes na escala da microbacia e tendiam a tornar-se mais fracas ou não significativas na escala local. Trata-se de um exemplo onde o uso do solo na microbacia suplanta a capacidade da vegetação ripária em proteger o ecossistema lótico.

Para Wang et al. (1997), o uso do solo na bacia hidrográfica condiciona fortemente a integridade biótica de riachos do Wisconsin, EUA. Foram analisados 134 pontos de 103 riachos e uma análise de correlação indicou que a porcentagem de área florestada na bacia, seguida de uma zona tampão de cerca de 100 metros de mata ao redor dos canais são os fatores preponderantes, correlacionados positivamente ao índice de integridade biótica (IIB). Os autores indicam ainda que, dentre as bacias com predomínio de agricultura, há variação no índice, devido à existência de variação na fisiografia dos pontos amostrados. O índice foi derivado de métricas oriundas da composição e da abundância das comunidades de peixes (baseado em Karr, 1981). O uso do solo foi derivado de imagens áreas e modelos digitais de relevo tratados pelo software Arc/Info.

Stauffer et al. (2000) realizaram um estudo em 20 riachos escolhidos com base na presença ou ausência de mata como vegetação ripária (no segmento de amostragem) e pelo tipo de solo, conferindo às bacias estudadas um (potencial de) escoamento superficial baixo ou elevado. As variáveis consideradas foram obtidas de mapas temáticos derivados de fotografias aéreas, entre outros métodos. Os autores coletaram amostras de peixes, as quais foram representadas por um índice de integridade biótica (IIB). Estes, por sua vez, foram analisados a fim de verificar sua relação com a matriz de categorias dos riachos. Ambos fatores, presença de matas na zona ripária e potencial de infiltração do solo apresentaram correlações com os IIB calculados. Os maiores escores 
do IIB ocorreram em pontos de presença de mata e baixo potencial de escoamento superficial. Os autores concluíram que há maior influência das matas nos valores elevados do IIB devido ao relevo, quantidade de abrigos e volume de habitat, que estão ligados à ocorrência deste tipo de vegetação ripária.

O histórico de conversão da vegetação original para agricultura foi estudado por Harding et al. (1998), em 24 riachos em duas bacias hidrográficas da Carolina do Norte, EUA. Cerca de metade dos riachos apresentam-se totalmente florestados, enquanto a outra metade apresenta uso agrícola. Em cada um dos riachos, foram determinados os padrões de uso do solo em sete momentos, entre 1950 e 1990, utilizando-se de todo tipo de produto de sensoriamento remoto disponível. De cada microbacia, correspondendo aos 24 riachos, foram determinadas diversas métricas visando determinar a porcentagem de mata em zonas tampão de $30 \mathrm{~m}$ ou $100 \mathrm{~m}$ no sentido lateral, e entre um e dois quilômetros à montante do ponto de amostragem da biota aquática. Técnicas de análise multivariada permitiram aos autores identificar que a agricultura tem efeitos deletérios sobre o biota, mesmo quando há recomposição da vegetação ciliar, indicando que o histórico do uso da terra influencia a estrutura e a composição das comunidades, mesmo quando, no presente, as microbacias apresentam-se florestadas. Concluem também que a preservação de pequenos fragmentos de mata ao redor dos riachos não mantém a diversidade de insetos e peixes, sendo necessária a preservação de boa parte, ou toda a microbacia. Conclusões similares foram retiradas de um estudo com delineamento semelhante, mas tratando de comunidades de macroinveterbrados bentônicos (Sponseller et al., 2001).

$\mathrm{Na}$ mesma linha do trabalho anterior, Jones et al. (1999) concluíram que se o desmatamento em áreas naturais for planejado, com pouca ou nenhuma alteração na zona ripária, as alterações sobre a estrutura das comunidades serão poucas ou inexistentes. Entretanto, os autores ressaltam que, mesmo rios em microbacias totalmente florestadas, não toleram a destruição de muito mais que um quilômetro de extensão à montante do ponto considerado. As principais alterações observadas após o desmatamento nas microbacias estudadas foram: 1) redução de espécies que não guardam (ou escondem) seus ovos e que são dependentes de corredeiras rápidas, rasas e 
livres de sedimentos finos; e 2) aumento na densidade de espécies guardadoras da prole (que limpam seus ninhos), ou especialistas de poços, de águas mais calmas e profundas. Neste caso, foram estudados 12 segmentos de riachos em área desmatadas de microbacias de predomínio de floresta ( $>95 \%$ ), mas com extensões variáveis de retirada da mata ripária (entre $0-5,3 \mathrm{~km}$ de extensão).

Scott (2001) analisou, além do uso da terra em microbacias, também aspectos da morfologia do canal, posição relativa da microbacia, e aspectos históricos das modificações antrópicas sobre os sítios de estudo na Carolina do Norte, EUA. Dentre os diversos modelos construídos das relações entre atributos da paisagem e variáveis dos riachos, a cobertura florestal respondeu pela maior parte da variação em praticamente todos, validando as predições dos efeitos do enriquecimento de nutrientes, aquecimento (poluição térmica) e sedimentação causada por distúrbios na paisagem. O autor indica quatro associações discretas de peixes, desde aquelas dominadas por especialistas dependentes de águas mais frias e substratos consolidados, de partículas grandes, até aquelas dominadas por espécies de porte maior, maior longevidade, "cosmopolitas" (isto é, ubíquas), de águas mais quentes, que não dependem de substrato rochoso para reprodução e ocorrem tipicamente em segmentos mais antropizados. Assim, ficaram demonstrados efeitos cumulativos das alterações antrópicas na paisagem, desde a escala de micro-habitat até canais em unidades fisiográficas distintas.

McCormick et al. (2001) utilizaram imagens do sensor TM do Landsat para elaborar mapas capazes de gerar variáveis sobre a qualidade (integridade) da bacia hidrográfica à montante do ponto de amostragem de peixes. Estes foram amostrados em 309 localidades, como parte de um programa sobre o monitoramento e inventário da qualidade de riachos, promovido pela Agência de Proteção Ambiental americana. O objetivo central deste trabalho foi o de verificar variáveis que apresentam correlação com o IIB desenvolvido pela agência. Os autores incluem suas medidas de qualidade da bacia em um fator (multivariado) representativo da qualidade geral do habitat de amostragem dos peixes. Os autores encontraram pequena correlação entre a porcentagem de uso agrícola nas microbacias e o IIB, e atribuem este fato ao longo 
tempo de uso da terra por atividades humanas, que poderia ter causado degradação generalizada da ictiofauna, irrespectivo ao grau de integridade da bacia.

Em outro trabalho versando sobre a integridade biótica dos riachos a partir de amostras da comunidade de peixes, Snyder et al. (2003) também lançam mão de técnicas de sensoriamento remoto e geoprocessamento com o objetivo de delinear variáveis capazes de descrever os impactos das atividades antrópicas. Os autores utilizaram imagens de satélite (Landsat/TM) para derivar métricas sobre toda a microbacia e fotografias digitais e fotografias aéreas para análises sobre a vegetação ripária dos segmentos amostrados. Diversas métricas foram propostas, variando-se a largura da "zona ripária" ao redor dos canais e a extensão (à montante) desta área tampão em relação ao ponto de amostragem. Os autores concluíram que mesmo pequenas áreas urbanas ( $>7 \%$ da área da microbacia, todas de primeira a segunda ordem) produzem fortes efeitos sobre a comunidade de peixes, revelados por baixos escores do IIB. Outros resultados indicam que zonas ripárias estreitas (e curtas) não são capazes de proteger adequadamente o meio lótico, pelo menos em áreas de declividade elevada. É ressaltada também a ocorrência de autocorrelação (dependência espacial) entre categorias de uso do solo e outros atributos da paisagem, como topografia e geologia, o que complica a interpretação dos dados.

Pelo demonstrado acima, ainda são poucos os trabalhos que explicitam as relações entre uso da terra (na microbacia) e as comunidades de peixes, especialmente no que diz respeito a análises quantitativas. Neste ponto, trabalhos focando uso da terra como fatores causais sobre um ponto de amostragem à jusante (um vertedouro) são escassos. Estes trabalhos, que visam descrever as comunidades de peixes mormente em termos dos efeitos à montante ignoram, parcialmente, a dificuldade inerente de utilizar seres vivos (em especial, animais) como indicadores de saúde ambiental. Em ambientes tão fortemente hierarquizados e dinâmicos como são os riachos (de cabeceira em particular) esta ligação (indicador vertedouro-microbacia) é particularmente complexa (Schlosser, 1991; Bretschko, 1995).

A despeito do reduzido universo de trabalhos práticos versando sobre uso da terra e comunidades de peixes de riachos, diversas sínteses teóricas têm ressaltado 
aspectos diversos desta interação, mais propriamente ligados à ecologia de paisagem. Que os sistemas fluviais são altamente organizados, especialmente na escala longitudinal, é assunto dominado já há vários anos, como pode ser observado na revisão de Petts \& Amoros (1994), ou mesmo pelo conceito do rio como um contínuo (Vannote et al., 1980). O conceito atual sobre o ecossistema fluvial é de que nele existe uma série de processos e fatores em escalas espaciais hierarquizadas, sendo que as mais elevadas impõem restrições à manifestação das demais (Forman \& Godron, 1986). Assim, os ambientes lóticos podem ser vistos como uma série de habitats arranjados em escalas espaciais decrescentes (Frissel et al., 1986), cuja formação e manutenção (i. e., processos) obedecem também a uma escala temporal (Ward, 1989; Hawkins et al., 1993; Hildrew \& Giller, 1995). Segundo Stanford (1996), uma compreensão dos processos atuando nas escalas espacial e temporal é crucial para a tomada de decisões relacionadas à preservação e à manutenção dos ecossistemas lóticos. Em sua forma mais simples, a diversidade e a ocorrência de peixes são relacionadas a esta hierarquia através de indicadores de posição hidrológica relativa, como as formas de ordenação de canais (Osborne \& Wiley, 1992).

Nos últimos anos, alguns modelos conceituais e trabalhos teóricos foram propostos, buscando integrar os diferentes níveis das escalas espaciais, sazonalidade e atributos biológicos das espécies, como comportamento e ciclos de vida (Schlosser, 1990, 1991, 1995; Sedell et al., 1990; Gregory et al., 1991; Bretschko, 1995), ou ao próprio condicionante geomorfológico, como o Conceito de Domínios de Processos (Montgomery, 1999). São correntes, neste ponto, conceitos próprios da ecologia de paisagem, como fragmentação, complementaridade e suplementaridade de habitats, migração entre "manchas" de paisagem e outros (Dunning et al., 1992; Schlosser, 1995).

Estes conceitos (da ecologia de paisagem) aplicam-se a uma dimensão espacial própria das bacias hidrográficas $\left(10^{8}\right.$ metros, Frissel et al., 1986), e acima da qual fala-se em fatores geográficos, próprios da estruturação de faunas regionais. Marsh-Matthews \& Matthews (2000) tratam, por exemplo, de fatores nesta escala, em oposição a dimensões menores, como a interação entre os meios terrestre e aquático (uso da terra), ao analisar 13 drenagens independentes no meio oeste norte-americano. Para estes autores, a 
composição das assembléias (comunidades) de peixes é regulada tanto pela latitude como por fatores relativos à estrutura do canal, mas a complexidade destas assembléias (abundâncias relativas das espécies) é controlada fortemente por fatores locais, de habitat. Argent et al. (2003), na mesma linha, determinaram um esquema de análise hierarquizado visando à predição da ocorrência de uma espécie baseado em fatores regionais, históricos, antrópicos e locais.

Schlosser (1991) encara a ecologia de paisagem como o estudo das relações estruturais entre diferentes elementos da paisagem, seja pelo movimento de água, nutrientes, matéria orgânica ou animais, assim como as mudanças nestas relações ao longo do tempo, mediada por fatores naturais ou antrópicos. Schlosser (1995) cita três fatores como críticos para o ciclo de vida das (diferentes) espécies de peixes: interações funcionais no ecótono terra-água, relações espaciais de habitat em larga escala (preponderante para espécies migradoras de média-longa distância) e a distribuição de refúgios de condições ambientais extremas (induzidas pelo homem ou não).

Quanto a estes fatores, estudos sobre a importância de troncos de árvores na estruturação dos canais (Montgomery, 1996), visto que o espaçamento entre poços pode ser crítico para diversas espécies de peixes (Taylor, 1996; Lonzarich et al., 1998; Lonzarich et al., 2004), é um exemplo que remete diretamente às questões tratadas por Schlosser. Note-se que estes são fatores determinados fortemente pela capacidade de natação, deslocamento e atributos próprios da espécie, relacionados a sua área de vida. Esta, nos peixes, varia muito, ocorrendo desde espécies sedentárias (ocupando alguns metros, Hill \& Grossman, 1987) até outras, migratórias de longa distância (percorrendo milhares de quilômetros, Barthem \& Goulding, 1990), atributo que é fundamentalmente alométrico positivo (Minns, 1995).

Meixler (2000), por exemplo, desenvolveu uma série de mapas a partir do conhecimento da biologia de duas espécies de salmonídeos, notadamente quanto às suas exigências de habitat (temperatura, cobertura florestal e tipos de substrato) e capacidade de movimentação ao longo da paisagem, considerando pequenos reservatórios e saltos. Estes mapas, construídos a partir de um SIG, tinha como objetivo guiar iniciativas 
futuras na restauração de sistemas lóticos junto ao Lago Ontário, na região norte dos EUA.

Snodgrass et al. (1996), de modo semelhante, relacionaram a estrutura de comunidades de peixes de várzeas isoladas (eventualmente conectadas a sistemas lóticos) a atributos diversos dos locais onde ocorrem. Identificaram que entre os fatores preponderantes nessa estruturação estão a conectividade entre as várzeas e os rios, a freqüência de secagem total da várzea e a proximidade de poços permanentes (nos rios) com indivíduos fundadores, que ocorrem em proporções relativas diferentes, com diferentes capacidades de colonização destes ambientes.

Tendo em vista estes exemplos, diversos esquemas conceituais para a análise dos atributos da paisagem em relação à ecologia dos peixes têm sido propostos, como o de Imhof et al. (1996) e o de Poole (2002), mediados pelas considerações de Wiens (2002), que transporta, tal qual a sugestão de Schlosser (1995), os conceitos da ecologia de paisagem para o sistema aquático. Ward \& Tockner (2001) sugerem a adoção de um conceito unificado de diversidade, incorporando o caráter dinâmico das paisagens fluviais nas quatro dimensões propostas por Ward (1989). Este conceito deveria ser capaz de coordenar os esforços de conservação destes sistemas para se restabelecer a diversidade funcional do corredor fluvial ativo, retomando o paradigma do Regime de Fluxos Natural, proposto por Poff et al. (1997).

É um campo recheado de idéias e conceitos, cuja instrumentação está disponível através dos modernos sistemas de sensoriamento remoto (aéreo e orbital), sistema de posicionamento global (GPS) e programas de computador amplamente diversificados, constituindo sistemas de informações geográficas disponíveis para a análise de qualidade de água (Griffith, 2002) e outras categorias de inventários de habitats aquáticos (Armantrout, 2001).

Como exemplo recente das questões levantadas nesta revisão e as possibilidades instrumentais para tratá-las podemos citar o trabalho provocativo de Fausch et al. (2002). Os autores ressaltam o método e a questão tratada em Torgersen et al. (2001), que estudou a distribuição de faixas de temperatura da água em uma bacia hidrográfica da ordem de poucos quilômetros, revelando importantes afluxos de água do 
compartimento hiporreico - rico em nutrientes - para o riacho em estudo. Este aporte, até então insuspeito, apresenta conseqüências diretas na abundância de salmonídeos. O estudo de Torgersen lançou mão de técnicas tão variadas quanto sensoriamento remoto orbital, videografia aérea (sensor na faixa termal) e censos visuais por mergulho livre em poços selecionados. Para Fausch et al. (op. cit.), este estudo é emblemático, pois enfoca uma escala espacial até pouco negligenciada, mas fundamental para a compreensão de eventos críticos do ciclo de vida dos peixes (Figura 2). Segundo estes autores, já se conhece bastante sobre as interações entre peixes lóticos, micro e mesohabitats e bacias de drenagem, com um lapso na escala de segmentos de canais. Falta, portanto, o entendimento de processos que ocorrem em uma escala de dezenas de metros a centenas de quilômetros, própria para ser tratada por meio de técnicas de sensoriamento remoto e geoprocessamento.

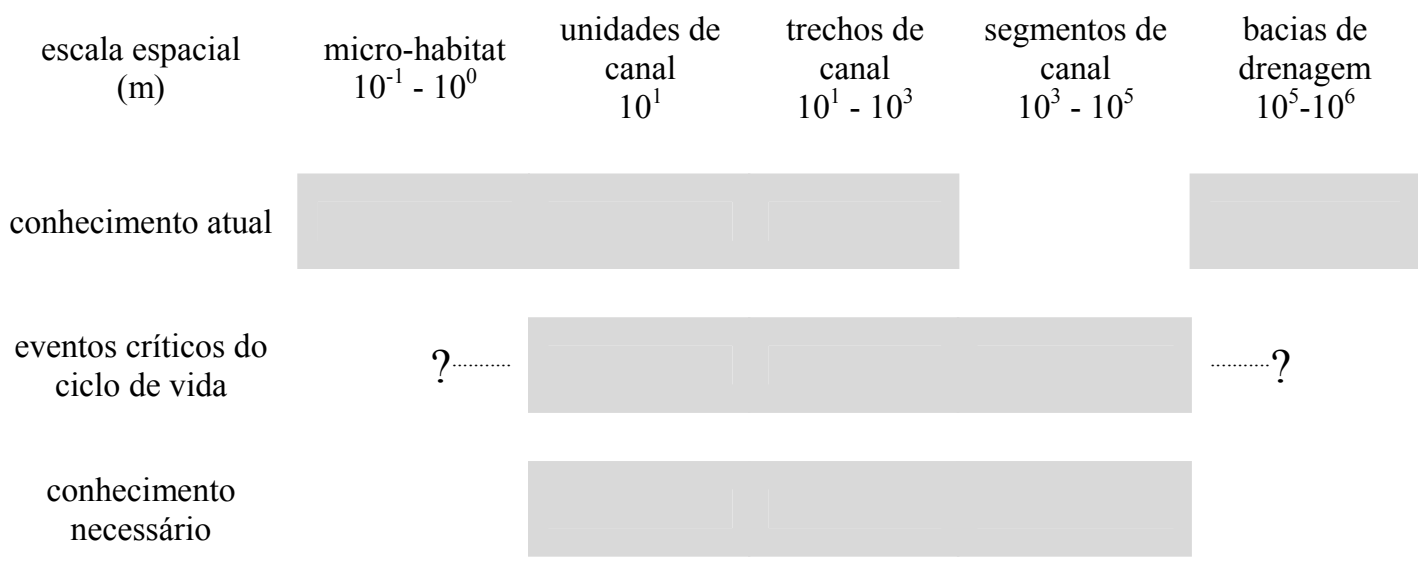

Figura 2 - Escala espacial do conhecimento corrente sobre peixes lóticos, amplitude provável de escalas de distribuição de eventos críticos do ciclo de vida de muitas espécies, e a escala de estudos necessária para amostrar e predizer atributos de populações e comunidades de peixes em paisagens fluviais. Adaptado de Fausch et al. (2002) 


\section{MATERIAL E MÉTODOS}

\section{1 Área de estudo}

\subsubsection{Situação geográfica, política e hidrografia}

A Bacia do Rio Corumbataí, uma sub-bacia da margem direita do Rio Piracicaba, está localizada na região centro-leste do Estado de São Paulo, aproximadamente entre os paralelos $22^{\circ} 04^{\prime} 46^{\prime \prime} \mathrm{S}$ e $22^{\circ} 41^{\prime} 28^{\prime \prime} \mathrm{S}$ e os meridianos $47^{\circ} 26^{\prime} 23^{\prime \prime} \mathrm{W}$ e $47^{\circ} 56^{\prime} 15^{\prime \prime} \mathrm{W}$ (Figura $3)$.

Segundo o Plano Diretor do Projeto Corumbataí (2001), a bacia, com área de 170.775,6 hectares, pode ser dividida em cinco sub-bacias: Alto Corumbataí, com $31.801,7$ ha $(18,6 \%$ do total); Passa-Cinco, com 52.757,6 ha (30,9\%); Médio Corumbataí, com 29.316,6 ha (17,2 \%); Ribeirão Claro, com 28.174,9 ha (16,5\%); e Baixo Corumbataí, com 28.724,8 ha (16,8\%).

Os municípios inteiramente drenados por esta bacia são Ipeúna, Santa Gertrudes e Rio Claro e os parcialmente drenados são Analândia, Corumbataí, Itirapina, Charqueada e Piracicaba (Folhas São Carlos, Corumbataí, Itirapina, Rio Claro, Araras, São Pedro e Piracicaba na escala 1:50.000 do Instituto Brasileiro de Geografia e Estatística, de 1969 e 1971).

O Rio Corumbataí nasce no município de Analândia, a cerca de $1.050 \mathrm{~m}$ de altitude, e desemboca no Rio Piracicaba, no município de Piracicaba, a $470 \mathrm{~m}$ de altitude, em um percurso de cerca de $110 \mathrm{~km}$. Seus principais afluentes são: Rio PassaCinco (e deste, o Rio da Cabeça) e o Ribeirão Claro (Figura 4). A rede hidrográfica da Bacia segue apresenta, em geral, padrão dendrítico, mas podem ser visualizadas áreas 
distintas em termos de densidade de drenagem. A região do Alto Rio Corumbataí, junto aos municípios de Analândia e Corumbataí é bastante dissecada, o mesmo ocorrendo com certas áreas da região da Bacia do Rio Passa-Cinco. Nas região do Médio Corumbataí, na sub-bacia do Ribeirão Claro, junto aos municípios de Rio Claro e Santa Gertrudes, ocorre o oposto: áreas pobremente dissecadas, com baixa densidade de drenagem. Este padrão acompanha as classes de relevo presentes na Bacia.

\subsubsection{Geologia}

A Bacia do Rio Corumbataí está localizada em uma região onde se misturam afloramentos de rochas de origem Paleozóica (Grupo Itararé, Formação Tatuí e Grupo Passa-Dois, com as formações Irati e Corumbataí), Mesozóica (Grupo São Bento, formação Pirambóia e rochas magmáticas intrusivas associadas) e Cenozóica (Formação Rio Claro) (Figura 5). Em virtude da formação geológica denominada Domo de Pitanga, os tipos litográficos encontrados no alto e baixo cursos do Rio Corumbataí são mais novos do que aqueles presentes no médio curso do Rio. As formações presentes determinam a extração de alguns minerais de interesse econômico, como calcários dolomíticos da Formação Irati na região de Ipeúna, Piracicaba e bairro da Assistência (Rio Claro), arenitos finos da Formação Corumbataí, usados nas indústrias do pólo cerâmico da região, e as areias da Formação Rio Claro, exploradas especialmente na região de Ajapi (distrito de Rio Claro) (Perinotto, 2000). 


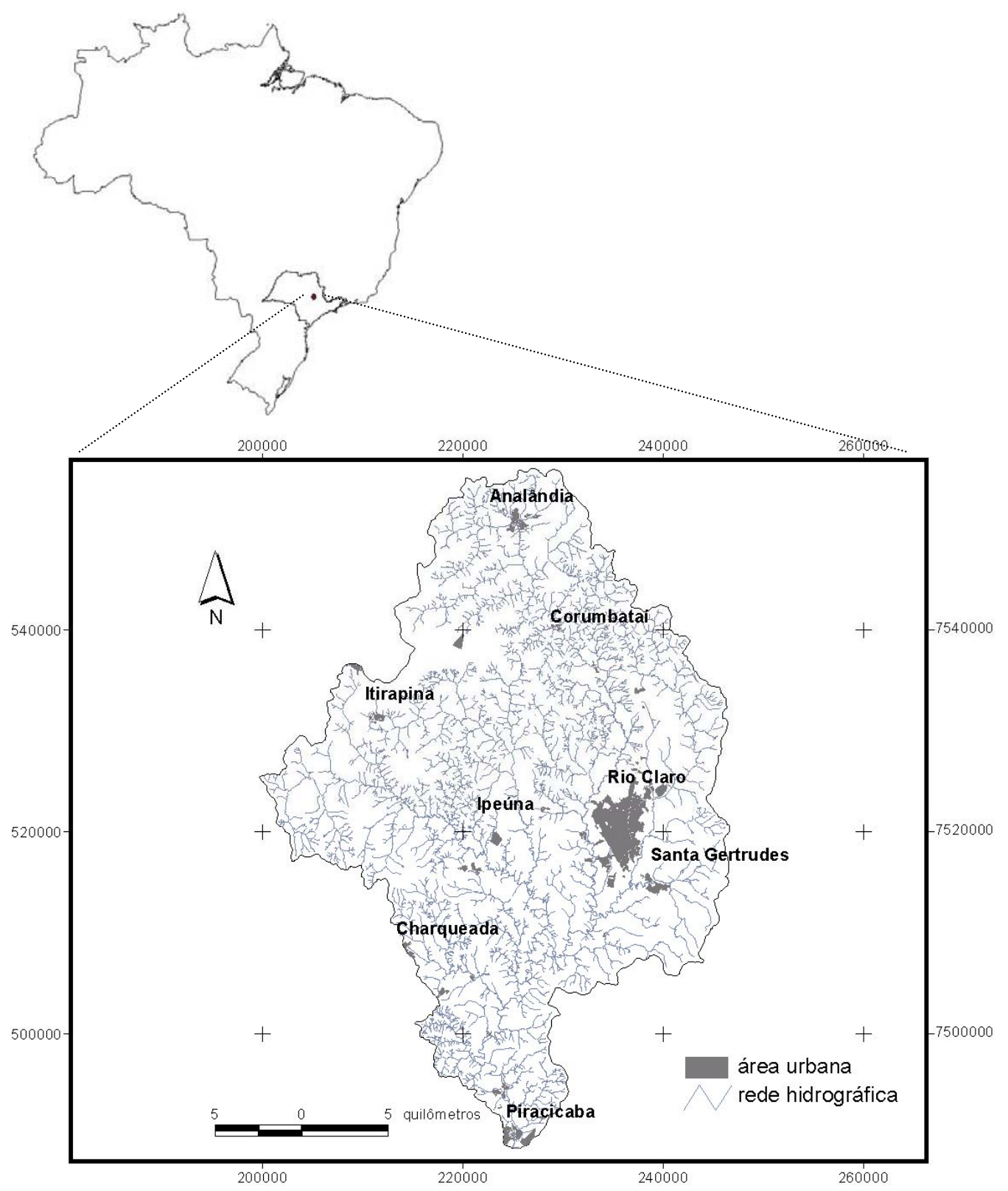

Figura 3 - Localização da Bacia do Rio Corumbataí, no Brasil e no Estado de São Paulo, e, no detalhe, localização dos centros urbanos e da rede hidrográfica. Coordenadas na projeção UTM, fuso 23 S, datum Córrego Alegre 


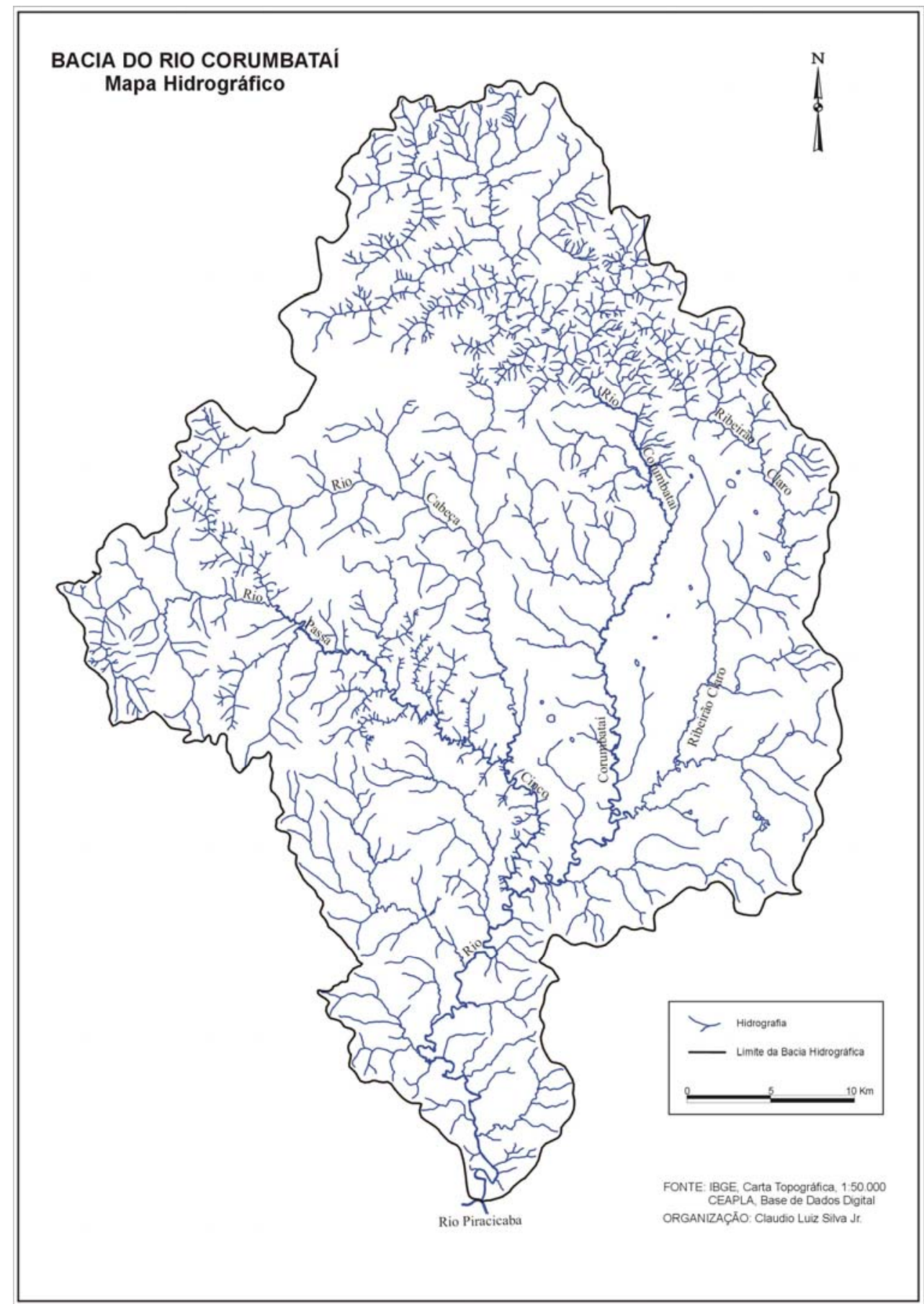

Figura 4 - Rede hidrográfica do Rio Corumbataí, Estado de São Paulo. Fonte: CEAPLA (2004, disponível em http://www.rc.unesp.br/igce/ceapla/biblioteca/ download. html) 


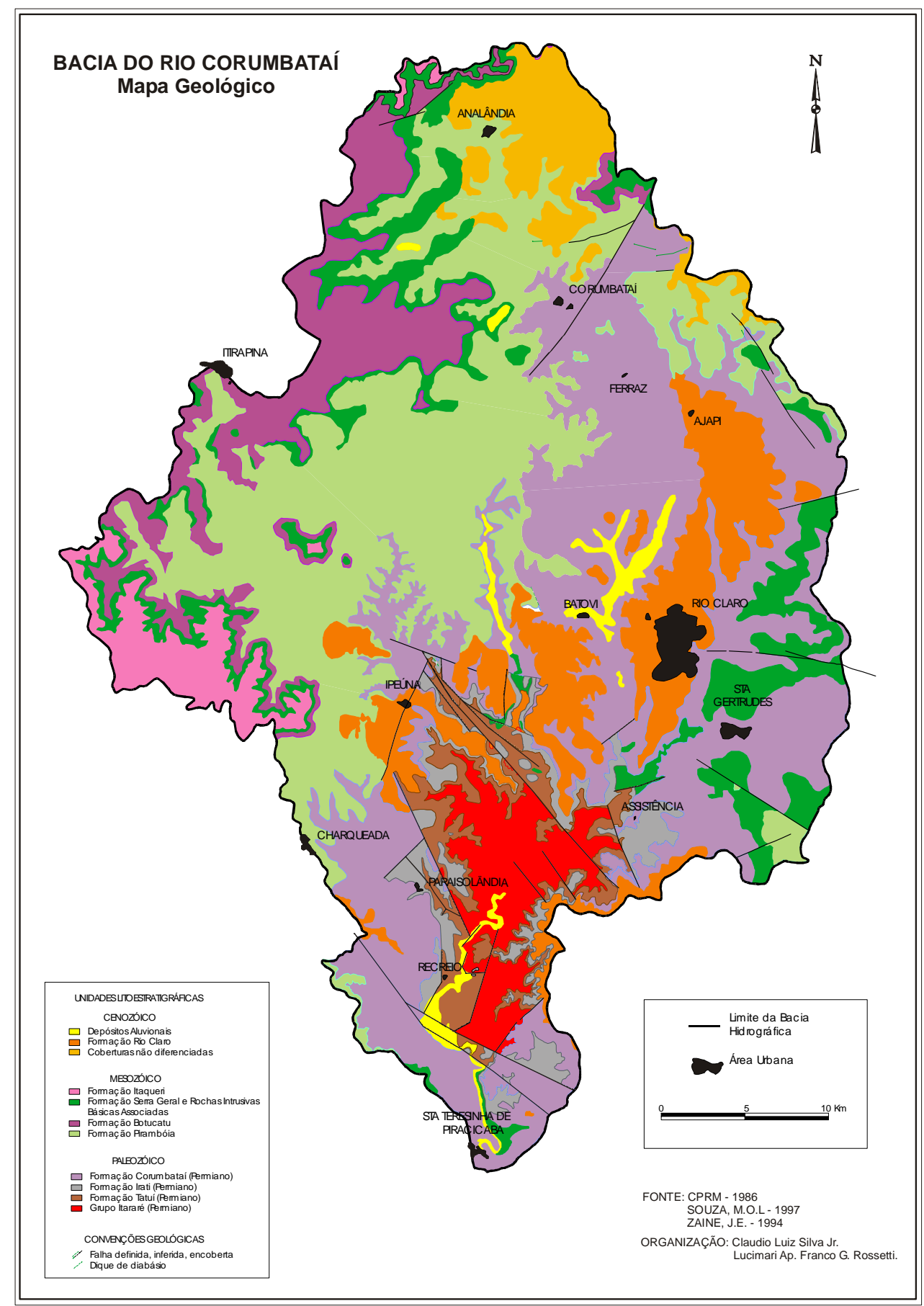

Figura 5 - Conformação da geologia da Bacia do Rio Corumbataí, São Paulo. Fonte: CEAPLA (2004, disponível em http://www.rc.unesp.br/igce/ceapla/ biblioteca/download.html) 


\subsubsection{Clima}

O clima da região onde está inserida a Bacia do Rio Corumbataí é do tipo Cwa na classificação de Köppen, isto é, subtropical, com inverno seco e verão chuvoso, e temperatura média do mês mais quente maior que $22^{\circ} \mathrm{C}$. O período de dezembro a março concentra as temperaturas mais altas e o bimestre junho-julho apresenta as temperaturas mais baixas, com a média de $17^{\circ} \mathrm{C}$ (Salati, 1996). O regime de chuvas apresenta duas estações bem definidas: seca, de março a setembro, quando chove menos de $30 \%$ da precipitação anual, e chuvosa, de outubro a fevereiro, concentrando mais de $70 \%$ da precipitação anual. A pluviosidade total anual média é de $1.422,3 \mathrm{~mm}$ para a série de 1962-1990 (Zavatini \& Cano, 1993).

\subsubsection{Relevo}

Desenvolvendo-se em maior parte na Depressão Periférica, na zona do Médio Tietê, com suas cabeceiras drenando as Cuestas Arenito-Basálticas da seção centroocidental do planalto paulista (IPT, 1981), a Bacia do Corumbataí pode ter seu relevo dividido em duas categorias predominantes. Na primeira, aparecem morrotes alongados e espigões com interflúvios sem orientação preferencial, topos de morros angulosos e achatados com vertentes de perfis retilíneos, drenagem de média a alta densidade, de padrão dendrítico e vales fechados. A segunda categoria apresenta colinas médias e amplas de interflúvios com áreas de $1 \mathrm{~km}^{2}$ até mais de $4 \mathrm{~km}^{2}$, topos de morros aplainados, vertentes com perfis convexos e retilíneos, conectando-se a drenagens de média a baixa densidade. Esta apresenta, aqui, padrão sub-angular, vales abertos ou fechados e planícies interiores restritas à presença de umas poucas lagoas perenes ou intermitentes (Koffler, 1993). A declividade, ao longo da bacia, é bastante variada, ocorrendo desde áreas planas até muito íngremes. As sub-bacias do Alto Corumbataí e Passa-Cinco abrigam a maior porção de áreas muito íngremes (Projeto Corumbataí, 2001). O modelo digital de elevação do terreno (MDT) construído para a Bacia do Rio Corumbataí fornece uma noção aproximada do relevo desta área, bem como a disposição de alguns rios e cidades (Figura 6). 


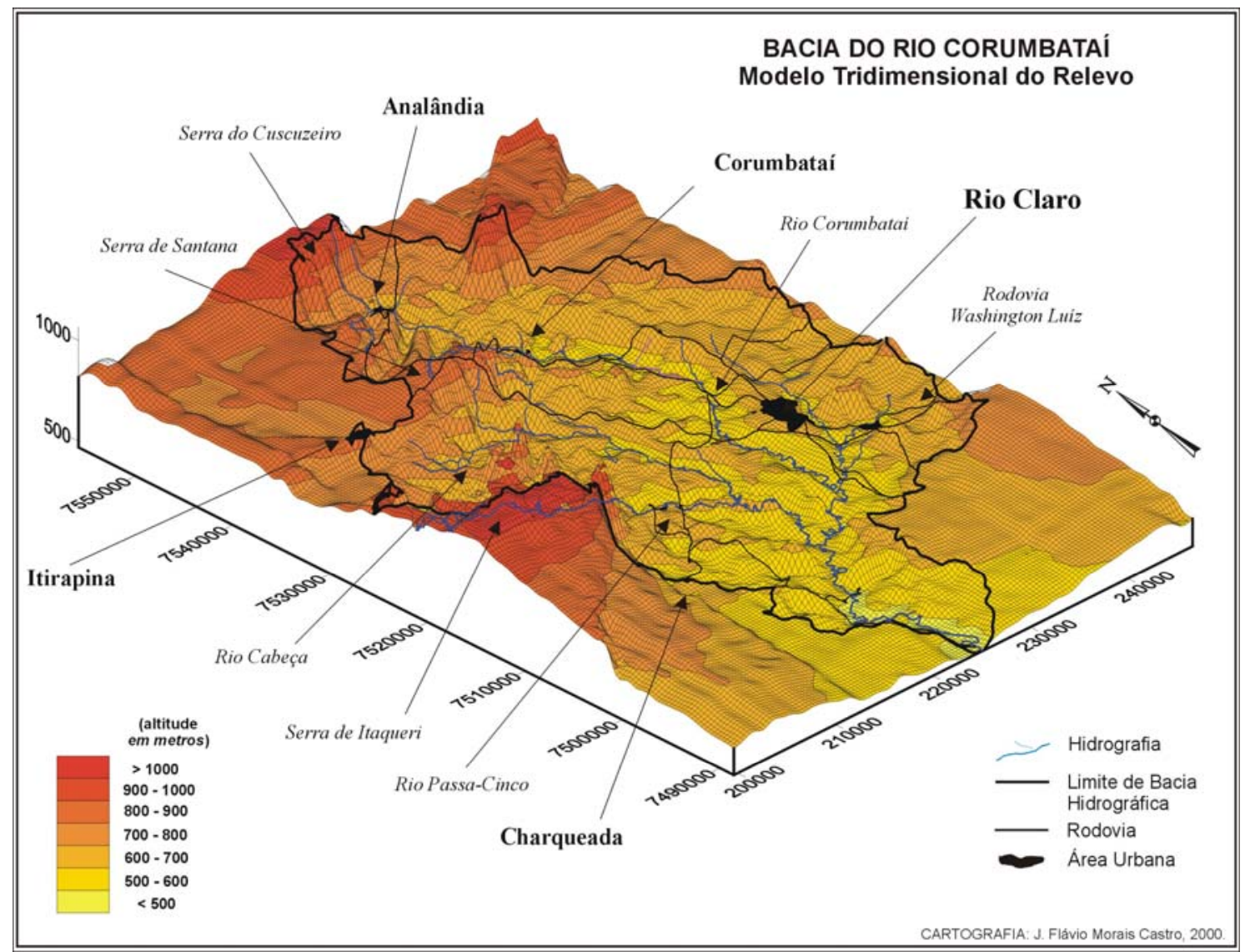

Figura 6 - Modelo digital de terreno da Bacia do Rio Corumbataí, destacando aspectos geográficos e políticos. (CEAPLA 2004, disponível em http://www.rc.unesp.br/igce/ceapla/biblioteca/download.html). Coordenadas na projeção UTM, fuso $23 \mathrm{~S}$, datum Córrego Alegre)

\subsubsection{Solos}

Solos dos grupos Podzólico Vermelho-Amarelos, Latossolos VermelhoAmarelos, solos Litólicos e as Areias Quartsozas perfazem praticamente 90 \% dos solos na área da bacia, com forte predomínio das duas primeiras categorias que somam, juntas, 65 \% da área (Projeto Corumbataí, 2001). Na Figura 7 é possível apreciar a distribuição dos tipos de solos na Bacia do Corumbataí. Parte dos solos da bacia são considerados 
como frágeis até mesmo para práticas agrícolas pouco invasivas, como o plantio direto (v. item 3.1.7).

\subsubsection{Vegetação nativa}

Rodrigues (1999) destaca cinco tipos de formações vegetais na área da bacia: floresta estacional semidecidual, florestas ripárias (ou floresta ribeirinha), florestas paludosas, floresta estacional decidual (mata seca) e cerrado, com diversas fisionomias. $\mathrm{O}$ autor frisa a complexidade de formações vegetais encontradas na região de Piracicaba e a elevada diversidade tipo gama, grande número de espécies fortemente relacionadas à diversidade de ambientes presentes. Destaque-se que os planos de reflorestamento propostos para a região devem levar em conta o conhecimento que (ainda) pode ser depreendido deste raro e depauperado acervo de formações florestais existentes na bacia (Projeto Corumbataí, 2001).

Para fins do presente trabalho, as diversas fisionomias vegetais nativas serão tratadas em uma única categoria: matas nativas, ou formações vegetais nativas.

\subsubsection{Uso e cobertura do solo recente, histórico e perspectivas}

O uso recente do solo pode ser observado na Figura 8. O mapa foi finalizado em 9/5/2001, e teve por base duas imagens do satélite SPOT-4, de 22/09/1999 e 18/07/1998, e uma do satélite LANDSAT-5, de 02/09/1999 (v. detalhes em Valente \& Vettorazzi, 2003). Seis coberturas vegetais são reconhecidas, além das áreas urbanas, da malha viária, da rede hidrográfica e de áreas de mineração. Predominam as pastagens (43,7 \% da área total) e os canaviais $(25,6 \%)$, seguido de formações de vegetação nativa $(11,1$ $\%$ ) e florestas plantadas (7,3\%). Nesta figura, as matas semi-decíduas, os cerrados e os campos cerrado foram reunidos na categoria "nativa", conforme citado acima. Nas subbacias do Passa-Cinco, Alto Corumbataí e Médio Corumbataí pode-se afirmar que a matriz, elemento dominante da paisagem, é de pasto, ao passo que nas sub-bacias do Ribeirão Claro e Baixo Corumbataí a matriz é de canaviais (Tabela 2, Figura 8). 


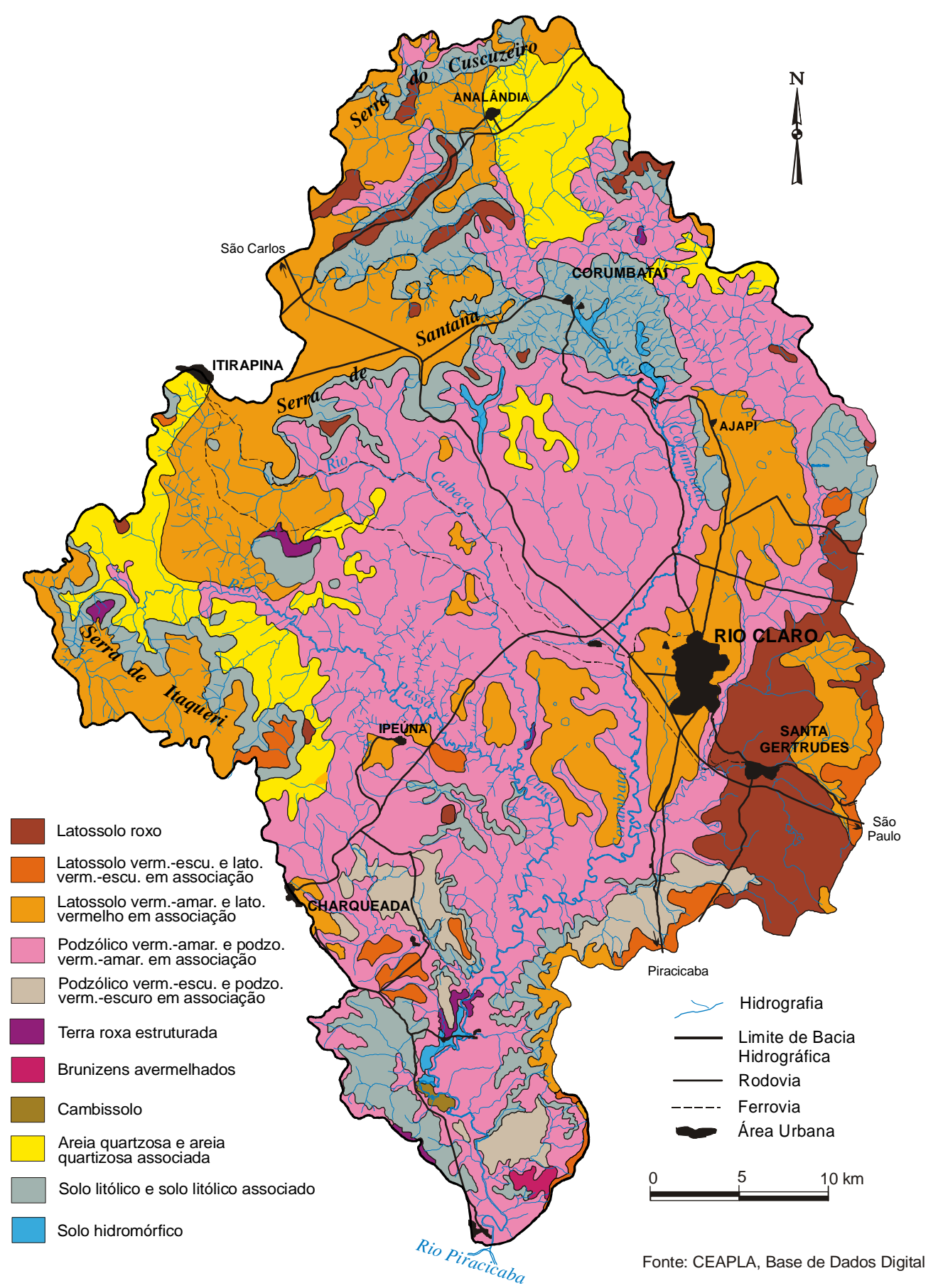

Figura 7 - Distribuição dos tipos de solo na Bacia do Rio Corumbataí, SP. Fonte: CEAPLA, disponível em http://www.rc.unesp.br/igce/ceapla/biblioteca/ download.html (2004) 


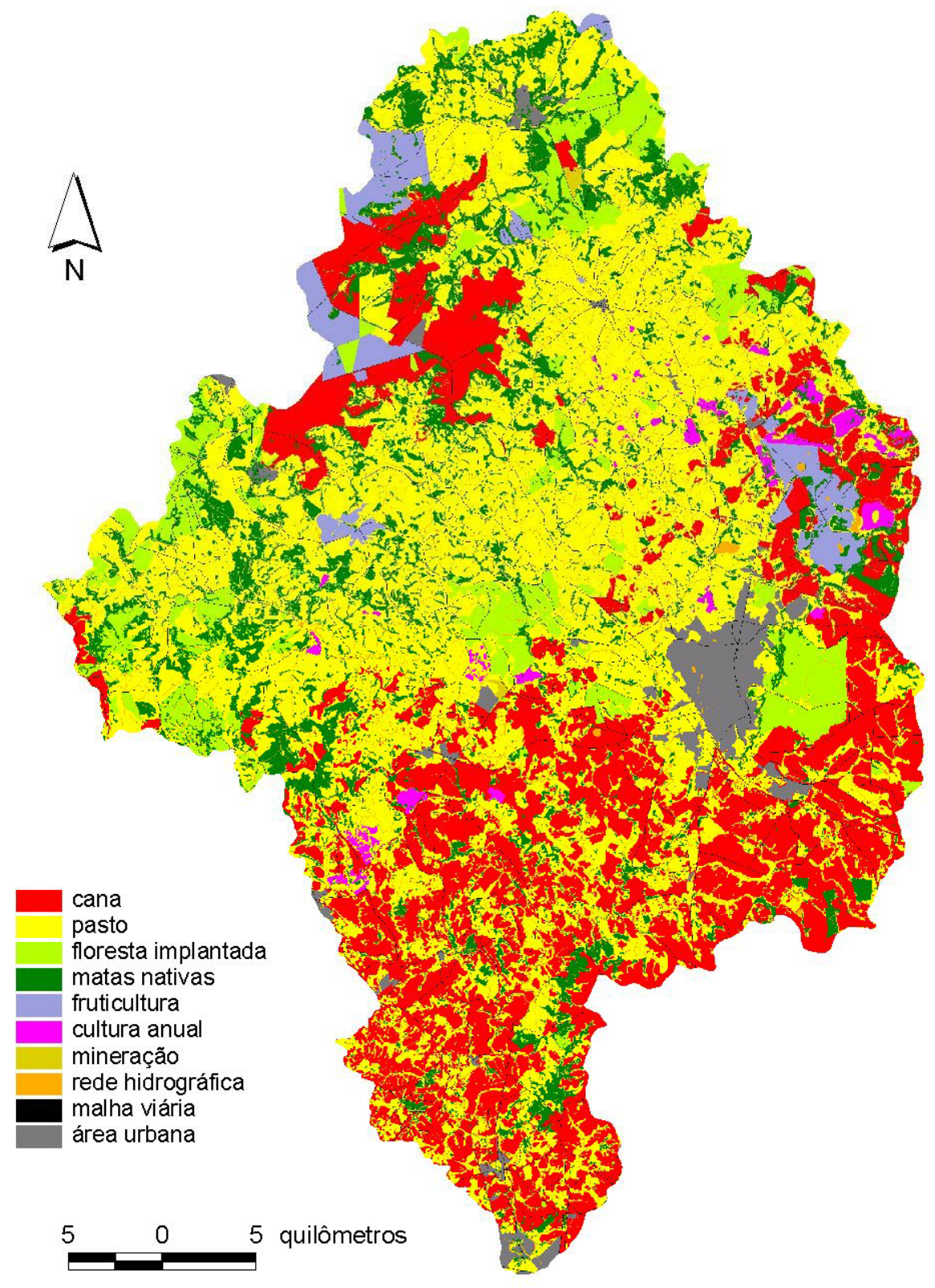

Figura 8 - Distribuição das classes de uso e cobertura do solo na Bacia do Rio Corumbataí. Fonte: Valente \& Vettorazzi (2003) 
Tabela 2. Porcentagem de cobertura de diferentes tipos de uso do solo nas sub-bacias do Alto Corumbataí (AC), Passa-Cinco (PC), Médio Corumbataí (MC), Ribeirão Claro (RC) e Baixo Corumbataí $\mathrm{BC}$ ), pertencentes à Bacia do Rio Corumbataí, Estado de São Paulo. Dados a partir do mapa do uso e cobertura do solo de $9 / 5 / 2001$

\begin{tabular}{lrrrrr}
\hline Classes de uso ou cobertura do solo & $\mathrm{AC}$ & $\mathrm{PC}$ & $\mathrm{MC}$ & $\mathrm{RC}$ & $\mathrm{BC}$ \\
\hline cana-de-açúcar & 11,7 & 14,1 & 24,8 & 39,3 & 49,3 \\
pastagem & 48,2 & 51,7 & 52,5 & 25,1 & 33,1 \\
floresta plantada & 9,6 & 10,6 & 3,1 & 10,0 & 0,3 \\
floresta nativa & 17,7 & 16,4 & 6,6 & 8,5 & 8,6 \\
fruticultura & 7,1 & 1,7 & 0,1 & 5,8 & 0,0 \\
cultura anual & 0,2 & 0,5 & 1,0 & 2,9 & 1,2 \\
mineração & 0,3 & 0,1 & 0,0 & 0,0 & 0,0 \\
área urbana & 1,2 & 0,5 & 7,2 & 4,5 & 2,3 \\
outros & 4,0 & 4,2 & 4,9 & 3,9 & 5,2 \\
\hline
\end{tabular}

Fonte: Valente (2001)

Na Tabela 2 nota-se que as sub-bacias do Passa-Cinco e do Alto Corumbataí são as que apresentam maior cobertura de vegetação nativa e, portanto, podem apresentar melhores condições para a conservação das espécies da fauna e da flora. De fato, segundo Valente (2001), estas duas sub-bacias apresentam não só a maior quantidade de fragmentos, como também são as sub-bacias que abrigam maior quantidade de fragmentos maiores do que 85 hectares. Nota-se também que estas duas sub-bacias são as que apresentam relevos mais acidentados (primeira categoria predominante descrita por Koffler, 1993), e os remanescentes de florestas nativas desenvolvem-se em áreas de elevada declividade. Também é nestas duas bacias que o processo de fragmentação da vegetação nativa é pouco menos severo, conforme foi atestado por Valente \& Vettorazzi (2002).

Assim, de uma paisagem totalmente recoberta por florestas, cerrados e campos, condicionados pelas características de clima e solo (Hueck, 1972; Victor, 1975; Koffler, 1993; Rodrigues, 1999) há, atualmente, uma paisagem fragmentada, fruto de ações 
humanas. Segundo o Projeto Corumbataí (2001), existem apenas 12,4 \% de cobertura florestal nativa, situação em desacordo com a legislação versando sobre áreas protegidas e áreas de preservação permanente, segundo as quais a vegetação nativa deveria somar $35 \%$ de toda a área da bacia. Devido às restrições impostas por alguns tipos de solo presentes na bacia existe, ainda, cerca de $15 \%$ de sua área que deveria ser destinada ao reflorestamento (Projeto Corumbataí, 2001). Pelo menos, estudos mais detalhados sobre sua aptidão agrícola deveriam ser efetuados, já que esta área é considerada como de fragilidade alta e severa até mesmo para o plantio direto (Cavalli et al., 2001).

O processo de desenvolvimento na bacia iniciou-se já no século XVIII com fazendas esparsas de criação de gado e da lavoura canavieira (Projeto Corumbataí, 2001). No entanto, é no princípio do século XIX que a região foi efetivamente ocupada, notando-se a fundação de Corumbataí, em 1821, e Rio Claro, em 1827 (Koffler, 1993), acelerando o desenvolvimento a partir de 1850, com a expansão da cultura do café. De acordo com Victor (1975), em seu clássico diagrama ilustrando o avanço da mancha de desmatamento sobre o Estado de São Paulo (Figura 9), por volta de 1907 a zona do Médio Tietê na Depressão Periférica já se encontrava quase totalmente desmatada. Com a decadência do ciclo do café, nas três primeiras décadas do século XX, são fortalecidas as atividades industriais e a cultura da cana-de-açúcar, em especial a partir da segunda metade desse século.

No futuro próximo, há tendência de expansão do cultivo da cana-de-açúcar, a qual é motivada, entre outros fatores, pelas recentes altas no preço do petróleo e incentivos globais à utilização de combustíveis derivados de fontes renováveis. 

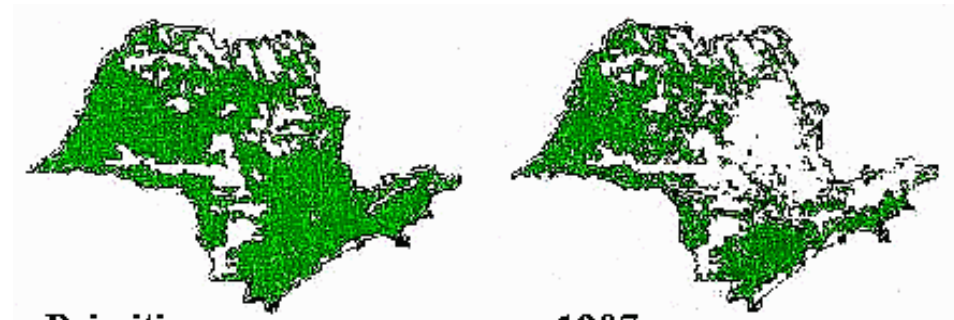

Primitivo

1907
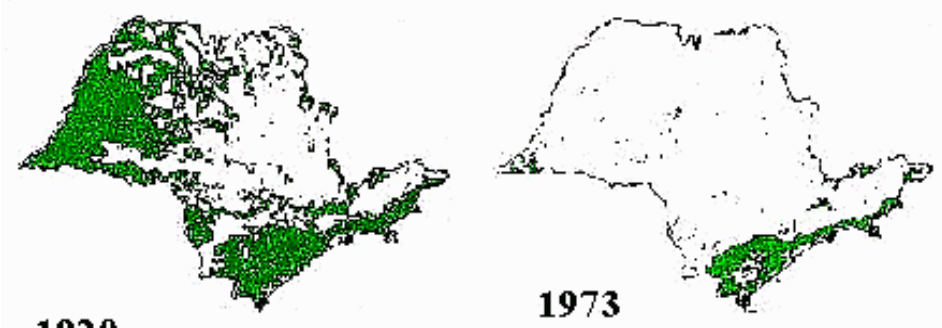

1920

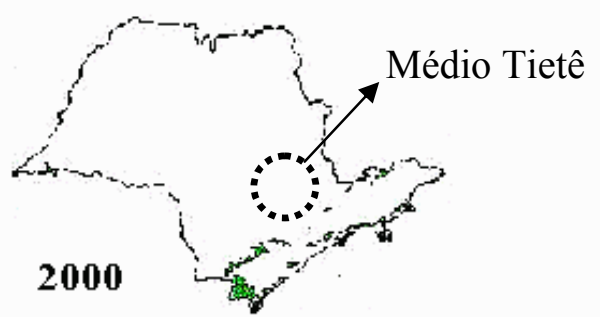

Figura 9 - Evolução da cobertura florestal nativa no Estado de São Paulo, com base em Vitor (1975). No mapa do ano 2000 foi representada a localização aproximada da zona do Médio Tietê

\subsection{Seleção das unidades amostrais}

A fim de atender o objetivo central deste trabalho: relacionar a riqueza e a abundância de espécies de peixes com o uso e cobertura do solo predominante de canaviais, matas nativas e pastagens em microbacias (além da cobertura do solo na zona ripária destas últimas microbacias), foi necessário empregar uma série de procedimentos a partir do banco de dados da Bacia do Rio Corumbataí (Projeto Corumbataí, 2001, Valente \& Vettorazzi, 2002, 2003). Deste banco de dados foi utilizado o mapa de uso do solo atualizado para o ano de 1999. A Figura 10 ilustra o processo geral de seleção destas unidades. 
As unidades amostrais selecionadas para a execução deste plano de trabalho foram, na medida do possível, alocadas nas sub-bacias mencionadas no item 3.1.1, mas foi conveniente dividir a sub-bacia do Passa-Cinco em duas, seguindo a área de drenagem do Rio da Cabeça. O contorno desta sub-bacia foi digitalizado em tela, a partir do MDT, método distinto do utilizado na delimitação das demais sub-bacias. No entanto, uma vez que as sub-bacias em questão têm área considerável - todas com mais de 20 mil hectares, considerou-se como negligíveis os erros oriundos da digitalização em tela no propósito geral deste trabalho.

Assim, neste estudo foram consideradas seis sub-bacias (Tabela 3). Uma certa dispersão dos sítios amostrais pelas sub-bacias consideradas foi almejada, dada a extensão da Bacia do Rio Corumbataí, pois a posição geográfica das unidade amostrais pode afetar a composição, riqueza e/ou abundância das espécies de peixes de riachos.

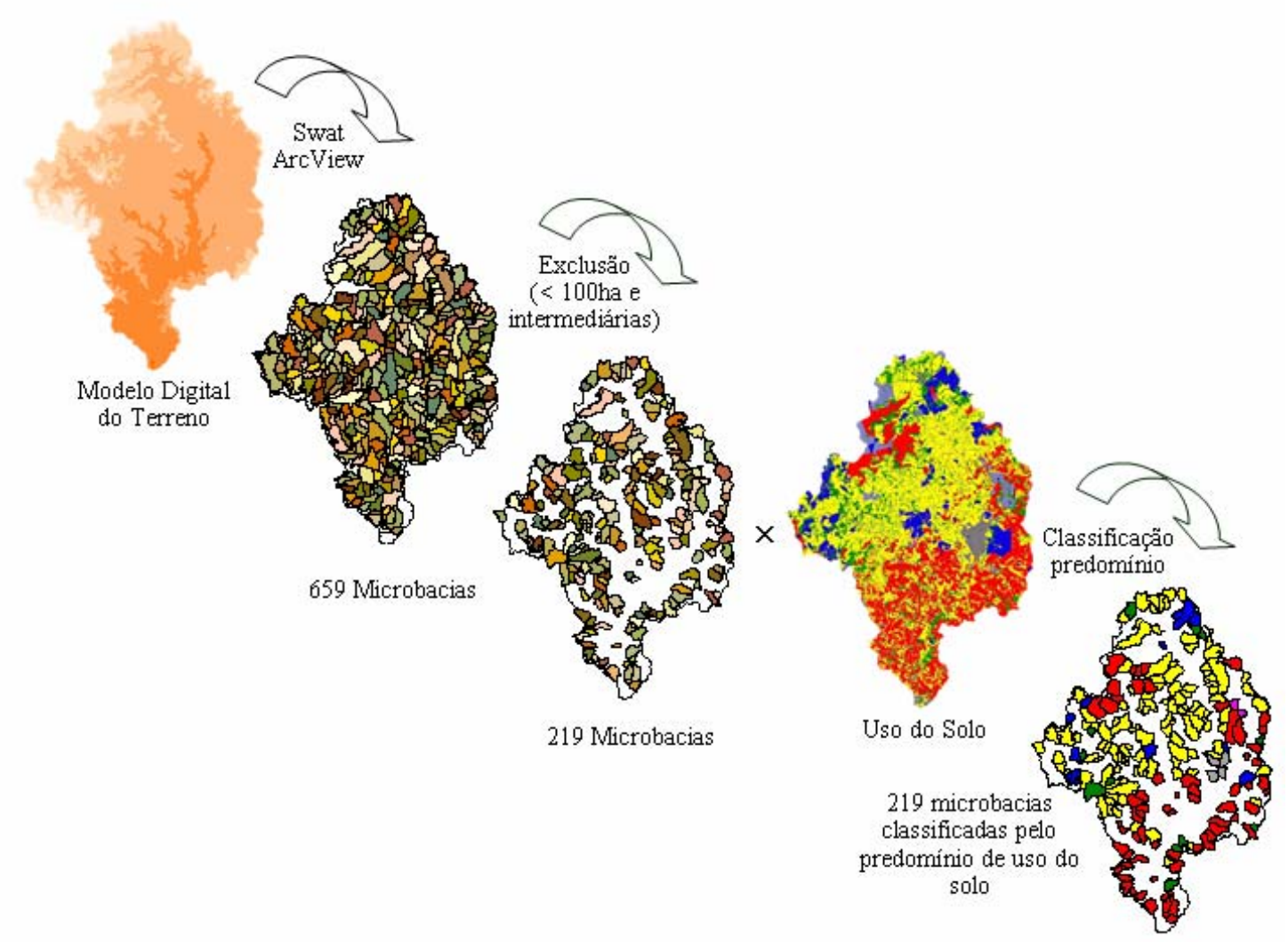

Figura 10 - Diagrama esquemático mostrando o processo de seleção de unidades amostrais 


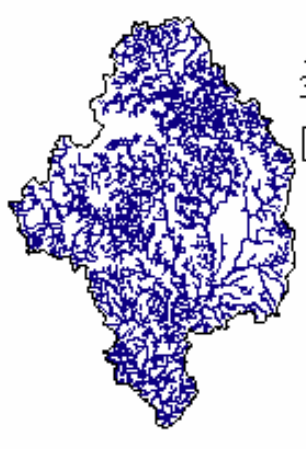

Rede de drenagem
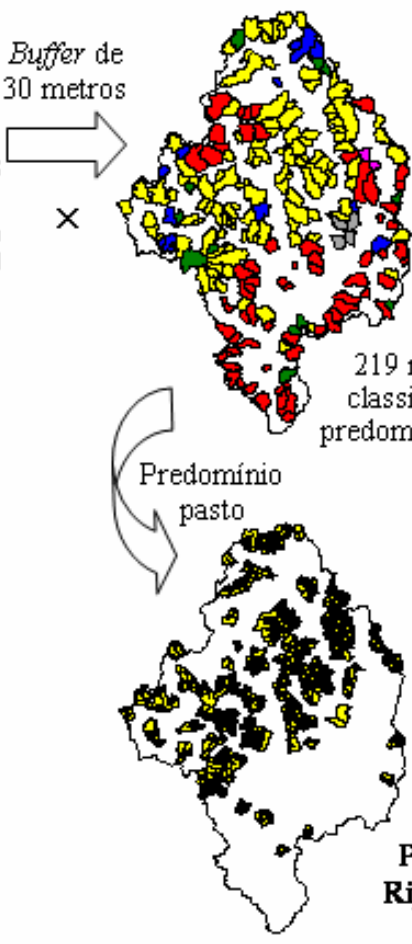

Microbacias com predomínio de pasto

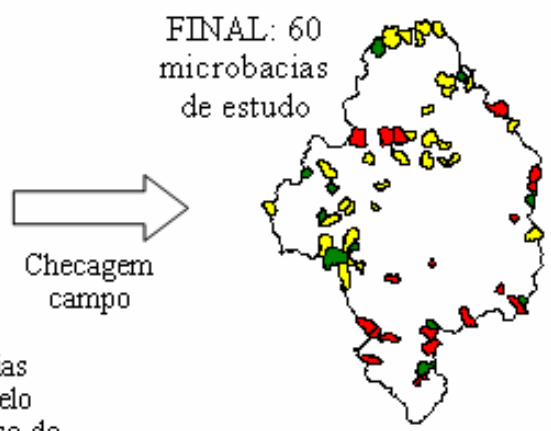

$\int \begin{gathered}\text { Checagem } \\ \text { campo }\end{gathered}$

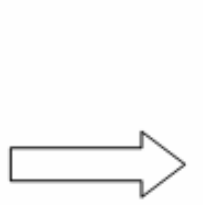

Classificação pelo critério:

Pasto: matas nativas na $\mathrm{APP}<45 \%$

Ripária: matas nativas na APP $>55 \%$

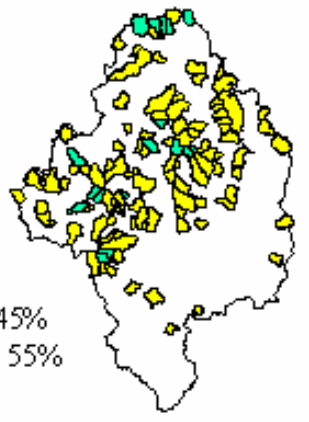

Microbacias ripárias e de pasto

Figura 10 - Diagrama esquemático mostrando o processo de seleção de unidades amostrais

Tabela 3. Áreas (em hectares) das seis sub-bacias da Bacia do Rio Corumbataí consideradas no presente projeto, derivadas de informações obtidas junto ao Projeto Corumbataí (2001)

\begin{tabular}{lc}
\hline Nome da sub-bacia & Área (hectares) \\
\hline Alto Corumbataí & $31.801,68$ \\
Passa-Cinco & $31.092,03$ \\
Rio da Cabeça & $21.665,57$ \\
Médio Corumbataí & $29.316,60$ \\
Ribeirão Claro & $28.174,90$ \\
Baixo Corumbataí & $28.724,84$ \\
\hline
\end{tabular}


A seleção de microbacias, ou unidades amostrais, foi incrementada através do software SWAT (Soil and Water Assessment Tool, disponível no endereço eletrônico http://www.brc.tamus.edu/swat/, 2004), dentro do ambiente do programa software Arc View 3.1 (Environmental Systems Research Institute, Inc. 1992-1998). Este processo foi adotado a fim de tornar a delimitação das microbacias automática, isenta de erros ou vieses do pesquisador nesta fase do planejamento do trabalho. Permitiu também uma escolha mais balanceada entre as diferentes regiões da Bacia do Rio Corumbataí.

O SWAT utiliza o MDT desenvolvido pelo Projeto Corumbataí, para determinar uma rede de drenagem, baseado no aspecto do terreno. Cada pixel da imagem tem seu valor de elevação comparado aos oito pixels adjacentes, o que determina a direção do escoamento superficial da água naquele ponto. Pode-se determinar um valor de origem (seed value) para que o software subdivida a bacia (do Rio Corumbataí) em microbacias preferencialmente deste tamanho. Baseado em informações obtidas em reconhecimento de campo realizado em 2001, foi utilizado o valor de 200 hectares. Este valor corresponderia em média a bacias de segunda a terceira ordem, ou 5-9 nascentes à montante do ponto de descarga de um bacia desta área. Em seguida, foi realizado o cruzamento do mapa, ou plano de informação, contendo as microbacias geradas pelo SWAT passíveis de serem amostradas neste trabalho, com o plano de informação sobre o uso e a cobertura do solo, produzindo uma tabela contendo as porcentagens de cobertura do solo em cada uma destas unidades amostrais.

Como resultado do procedimento de delimitação de microbacias, o SWAT gerou 659 delas, de área entre 0,04 ha e 2.019,60 ha. Muitas das pequenas bacias, menores que 100 hectares, representavam "erros" cometidos durante a modelagem das bacias, oriundos de imperfeições do próprio MDT. Excluindo-se estas microbacias, resultaram outras 356. Ainda, parte das microbacias criadas pelo software eram "intermediárias", isto é, elas tinham em sua porção mais à montante, um ponto de descarga de uma microbacia anterior, seja de cabeceira, seja de outra intermediária. No presente, foi necessário considerar apenas as microbacias de cabeceiras, pois só deste modo é possível isolar os efeitos do uso do solo na rede hidrográfica da microbacia considerada. Assim, excluídas as microbacias intermediárias, chegou-se ao número de microbacias 
passíveis de serem utilizadas neste projeto: 209. Estas microbacias possuem área média de 389,93 ha, com desvio padrão de 255,24 ha, variando entre 73,29 e 1.608,27 ha.

O código "ID" que consta nas tabelas ao longo deste trabalho é o identificador da microbacia gerado pelo software SWAT. As 659 microbacias geradas foram numeradas de modo que a microbacia mais ao norte recebeu o ID igual a 1, prosseguindo no sentido oeste-leste e então ao sul, até a microbacia junto à foz do rio Corumbataí no Rio Piracicaba, de ID igual a 659.

A Tabela 4 mostra a quantidade de microbacias por predomínio de uso ou cobertura do solo. Esta tabela indica que grande parte das microbacias apresentam coberturas de pastagens e canaviais. Isto é esperado, uma vez que estes tipos de uso do solo são considerados as matrizes de regiões distintas da Bacia do Rio Corumbataí. A Figura 11 mostra o mapa contendo as 209 microbacias, separando-as por tipo de uso e cobertura do solo predominante. Por cobertura predominante entende-se a classe de uso do solo de maior porcentagem em área presente na microbacia. Aqui também é possível verificar a dispersão viesada de microbacias de predomínio de canaviais, mais freqüentes nas sub-bacias do Baixo Rio Corumbataí e Ribeirão Claro.

Tabela 4. Número de microbacias de cabeceiras criadas pelos softwares SWAT e ArcView na Bacia do Rio Corumbataí, separadas pelo tipo de cobertura ou uso do solo predominante

\begin{tabular}{lc}
\hline Cobertura ou uso predominante & Número \\
\hline pastagens & 114 \\
canaviais & 65 \\
eucaliptais & 11 \\
matas nativas & 13 \\
fruticultura & 2 \\
áreas urbanas & 4 \\
TOTAL & 209 \\
\hline
\end{tabular}




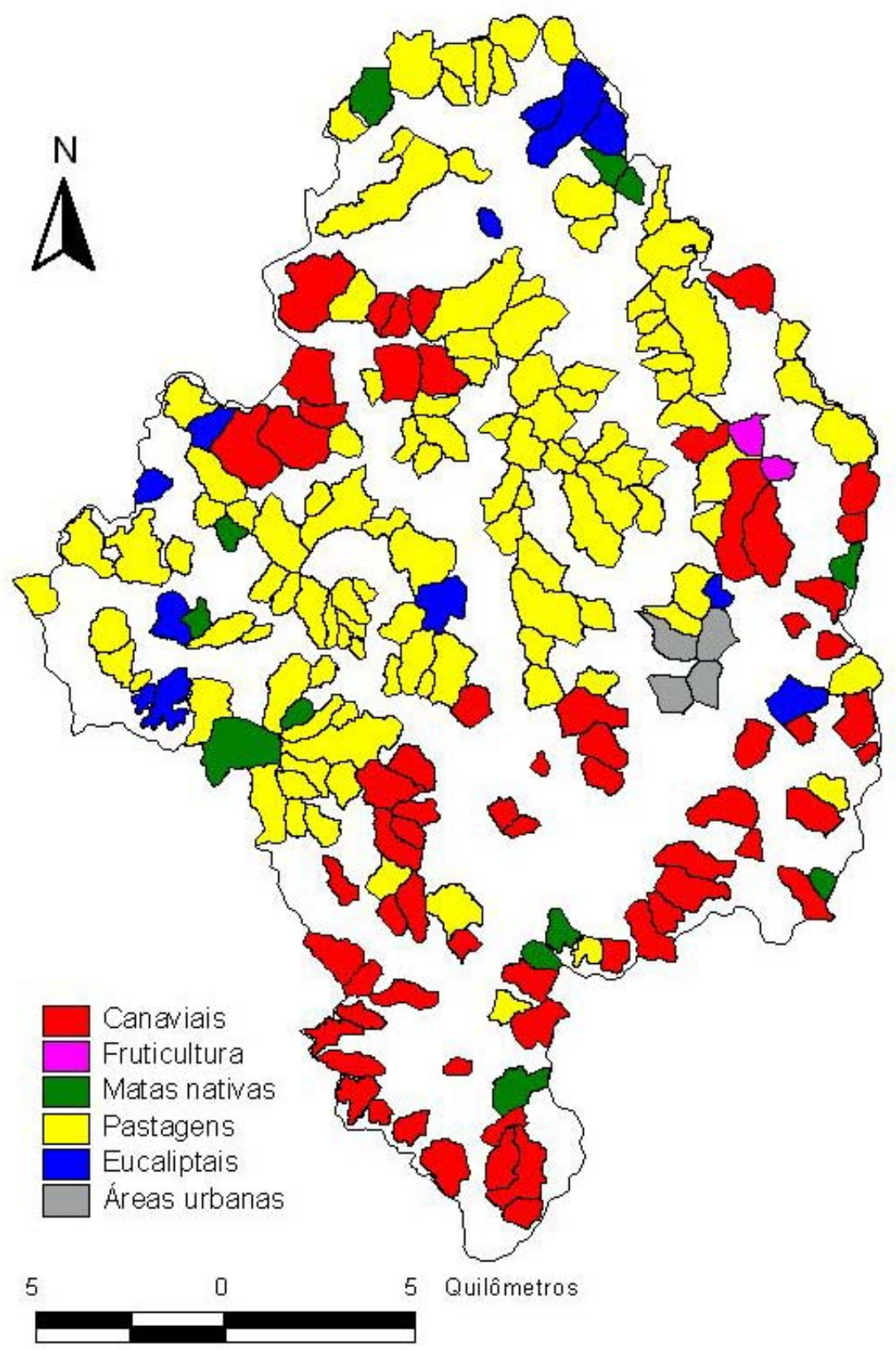

Figura 11 - Microbacias de cabeceira na Bacia do Rio Corumbataí, destacando-se a categoria de cobertura ou uso do solo dominante em sua área

As microbacias de predomínio de pastagens foram reclassificadas em dois grupos: microbacias cuja rede de canais apresenta, na área de um tampão de 30 metros, predomínio de matas nativas (50\% ou mais) ou pastagens (45\% ou menos de matas 
nativas). As microbacias nos dois grupos foram cunhadas de ripárias e de pastagens, respectivamente. O objetivo desta classificação foi o de selecionar microbacias para verificar as relações entre o tipo de vegetação da zona ripária e a estrutura das comunidades de peixes de riacho. Esta análise foi implementada através do ArcView e o banco de dados existente para a Bacia do Rio Corumbataí. Inicialmente, foi determinada uma zona tampão (buffer) de 30 metros de largura ao redor de todos os corpos de água (zona ripária), utilizando-se do mapa de rede hidrográfica. Este buffer foi cruzado com o mapa de contornos das microbacias definidas conforme explanado no item anterior e, finalmente, com o mapa de uso do solo (Figura 8). Feito isto, foi possível determinar as porcentagens de uso do solo na zona do buffer de cada microbacia. A escolha de uma zona ripária de 30 metros de largura em ambos os lados do canais justifica-se pelo que determina a legislação ambiental brasileira relativa às Áreas de Preservação Permanente (APP) (Lei Federal nº 7803/89).

Através do procedimento descrito acima, foram reconhecidas 17 microbacias de maior porcentagem de matas nativas em sua área ripária, isto é, maior do que $55 \%$. Note-se que, pelos critérios propostos, na zona ripária destas microbacias a cobertura do solo diferente de pastagens e matas nativas (“outros", na tabela) é bastante reduzida. Há predomínio de pastagens em sua área total, e a porcentagem de cobertura de matas nativas é a segunda categoria mais importante.

A Tabela 5 apresenta o número de microbacias de cabeceira separadas por região e predomínio de cobertura vegetal, além do grupo denominado "ripária". Para este estudo, no entanto, interessam apenas as microbacias de predomínio de canaviais, matas nativas e pastagens, com sua derivação, as microbacias ripárias. Portanto, do universo de 209 microbacias, 192 microbacias estavam disponíveis para amostragem segundo os critérios escolhidos neste plano. 
Tabela 5. Número de microbacias por sub-bacias da Bacia do Rio Corumbataí e por classes de uso ou cobertura do solo

\begin{tabular}{lcccccccc}
\hline Sub-bacias & $\begin{array}{c}\text { Pasta- } \\
\text { gens }\end{array}$ & $\begin{array}{c}\text { Cana- } \\
\text { viais }\end{array}$ & $\begin{array}{c}\text { Matas } \\
\text { nativas }\end{array}$ & $\begin{array}{c}\text { Euca- } \\
\text { liptais }\end{array}$ & Ripária & $\begin{array}{c}\text { Fruti- } \\
\text { cultura }\end{array}$ & $\begin{array}{c}\text { Áreas } \\
\text { Urbanas }\end{array}$ & TOTAL \\
\hline Alto Corumbataí & 20 & 4 & 3 & 4 & 5 & 0 & 0 & 36 \\
Médio Corumbataí & 20 & 10 & 1 & 0 & 3 & 0 & 2 & 37 \\
Rio da Cabeça & 17 & 6 & 0 & 1 & 3 & 0 & 0 & 26 \\
Ribeirão Claro & 6 & 16 & 2 & 2 & 0 & 2 & 2 & 30 \\
Passa Cinco & 27 & 3 & 5 & 4 & 4 & 0 & 0 & 43 \\
Baixo Corumbataí & 7 & 26 & 2 & 0 & 2 & 0 & 0 & 37 \\
TOTAL & 97 & 65 & 13 & 11 & 17 & 2 & 4 & 209 \\
\hline
\end{tabular}

Os números da Tabela 5, entretanto, não refletiram exatamente os pontos disponíveis para coleta após o reconhecimento de campo, quando se fez necessário ponderar o acesso de carro junto ao rio e a autorização dos proprietários para coleta, entre outros fatores. No reconhecimento de campo foram visitados cerca de 130 riachos, todos os disponíveis de matas nativas e ripárias, além da maior parte das microbacias de predomínio de pastagens e canaviais. Esta atividade consumiu cerca de 45 dias de campo. Duas grandes áreas da bacia não puderam ser amostradas pelo protocolo definido neste estudo. A primeira foi nas drenagens paralelas do noroeste da bacia, onde ocorrem canaviais em uma extensão considerável de um planalto (topo de cuesta), no divisor de águas entre as sub-bacias do Rio da Cabeça e do Alto Corumbataí (municípios de Itirapina e Analândia). Ali, os riachos desenvolvem-se em vales muito encaixados e de gradiente elevado, impedindo o acesso a praticamente todos estes corpos de água. $\mathrm{Na}$ sub-bacia do Médio Corumbataí, seja imediatamente ao oeste da cidade de Rio Claro, onde não foi possível encontrar os proprietários da terra para autorização, ou próximo ao bairro de Ajapi, onde diversos canais foram encontrados secos, poucas unidades amostrais puderam ser alocadas. Evitou-se, também, microbacias muito próximas a centros urbanos, como Piracicaba, Santa Gertrudes e Analândia.

Após a escolha das microbacias, tendo sido realizada a primeira amostragem num trecho que foi georreferenciado por um aparelho receptor de GPS, as microbacias 
foram ajustadas à mão no software ArcView. Deste modo, todas as microbacias em estudo apresentam o seu vertedouro exatamente no ponto de coleta.

\subsection{Unidades amostrais selecionadas}

Foram selecionadas 60 microbacias para atender aos objetivos deste estudo, sendo 19 de predomínio de canaviais, 11 de matas nativas, 16 de pastagens e 14 ripárias. A disposição destas microbacias pode ser consultada na Figura 12. Há um predomínio de unidades alocadas nas sub-bacias do Baixo Corumbataí, Passa-Cinco e Alto Corumbataí (12 microbacias cada), seguido do Ribeirão Claro (10), Rio da Cabeça (8) e Médio Corumbataí (6).

As Tabelas 6, 7, 8 e 9 trazem detalhes das localidades das unidades amostrais, municípios a que pertencem e suas coordenadas geográficas. Os nomes dos rios, localidades, bairros e fazendas foram obtidos das cartas topográficas citadas acima. Algumas toponímias não constam nos mapas, mas foram obtidas em campo pelo autor deste estudo, a partir de moradores das áreas amostradas.

O Anexo A mostra a data de coleta de dados em cada uma das microbacias, considerando as quatro campanhas nos anos de 2003 e 2004. Em apenas duas localidades (microbacias 47 e 308) não foi possível realizar a segunda amostragem, devido à proibição das atividades por parte dos proprietários. Nas três primeiras campanhas, alguns riachos foram amostrados fora da estação prevista para aquela campanha (respectivamente: dois, três e dois riachos, v. Anexo A). É possível afirmar, entretanto, que as mudanças de estações são graduais, não comprometendo os efeitos gerais na amostra daquela campanha. Por exemplo, os efeitos de chuvas e cheias nas microbacias só podem ser sentidos, na média, a partir de meados de novembro, intensificando-se até fevereiro e março, especialmente. 


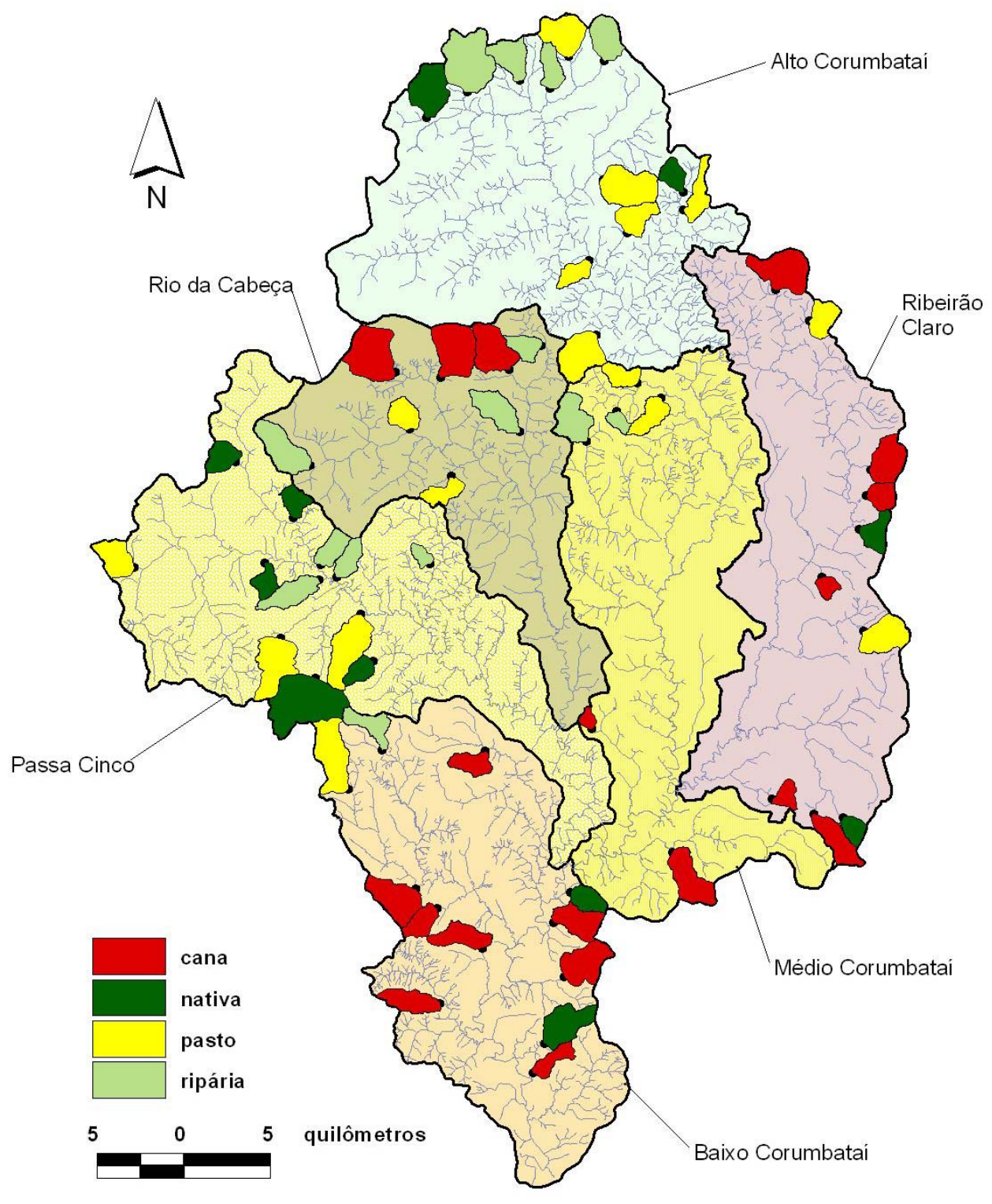

Figura 12 - Localização das 60 microbacias amostradas na Bacia do Rio Corumbataí, destacando-se as sub-bacias definidas para este estudo 
Tabela 6. Microbacias na Bacia do Rio Corumbataí, Estado de São Paulo com predomínio de canaviais. ID como discutido no texto. Sub-bacias: $c a=$ Rio da Cabeça, $r c=$ Ribeirão Claro e bc = Baixo Corumbataí. Coordenadas em UTM, fuso 23 S, Datum Córrego Alegre

\begin{tabular}{|c|c|c|c|c|c|c|}
\hline \multirow{2}{*}{ ID } & \multirow{2}{*}{ Sub-bacia } & \multirow{2}{*}{ Município } & \multirow{2}{*}{ Localidade } & \multirow{2}{*}{ Nome do rio } & \multicolumn{2}{|c|}{ Coordenadas (m) } \\
\hline & & & & & $\mathrm{x}$ & $\mathrm{y}$ \\
\hline 75 & $\mathrm{rc}$ & Corumbataí & - & Córrego do Jacú & 238.955 & 7.540 .060 \\
\hline 83 & $\mathrm{ca}$ & Corumbataí & Serra dos Padres & $\begin{array}{l}\text { Afluente da margem direita do Córrego do } \\
\text { Lajeado }\end{array}$ & 223.681 & 7.535 .482 \\
\hline 85 & $\mathrm{ca}$ & Itirapina & Fazenda Saltinho & Afluente do Córrego da Serra & 217.117 & 7.535 .350 \\
\hline 120 & $\mathrm{ca}$ & Corumbataí & - & Córrego Santana & 219.761 & 7.534 .999 \\
\hline 174 & $\mathrm{rc}$ & Rio Claro & Fazenda São José - Haras & Afluente da margem esquerda do Ribeirão Claro & 244.397 & 7.529 .720 \\
\hline 199 & $\mathrm{rc}$ & Rio Claro & Fazenda São José - Sede & Afluente da margem esquerda do Ribeirão Claro & 244.155 & 7.528 .232 \\
\hline 322 & $\mathrm{rc}$ & Rio Claro & - & Afluente da margem esquerda do Ribeirão Claro & 241.623 & 7.523 .579 \\
\hline 531 & $\mathrm{bc}$ & Charqueada & - & Afluente do Ribeirão Água Vermelha & 222.310 & 7.513 .561 \\
\hline 553 & $\mathrm{bc}$ & Rio Claro & Bairro Campo dos Cochos & Córrego dos Cochos & 228.418 & 7.514 .827 \\
\hline 561 & $\mathrm{rc}$ & Santa Gertrudes & - & Córrego da Fazenda Itaúna ou da Ponte Branca & 238.743 & 7.510 .805 \\
\hline 580 & $\mathrm{rc}$ & Santa Gertrudes & - & Córrego do Cajú & 241.157 & 7.509 .976 \\
\hline 608 & $\mathrm{bc}$ & Rio Claro & Bairro da Assistência & Córrego dos Gonçalves & 233.060 & 7.507 .789 \\
\hline 616 & $\mathrm{bc}$ & Charqueada & Paraisolândia & Córrego da Rocinha & 218.320 & 7.505 .666 \\
\hline 619 & bc & Charqueada & Bairro do Córrego da Onça & Córrego da Onça & 219.555 & 7.505 .532 \\
\hline 620 & bc & Piracicaba & Bairro dos Bernardos & Afluente da margem esquerda do Rio Corumbataí & 226.200 & 7.503 .757 \\
\hline 632 & $\mathrm{bc}$ & Charqueada & Bairro do Recreio & Córrego do Cateto & 222.114 & 7.502 .289 \\
\hline 634 & bc & Piracicaba & Bairro do Recreio & Córrego Tamandupá & 226.803 & 7.500 .635 \\
\hline 635 & bc & Charqueada & Bairro Santa Luzia ou Caiapiá & Córrego Caiapiá & 219.703 & 7.499 .129 \\
\hline 652 & $\mathrm{bc}$ & Piracicaba & Bairro Costa Pinto & Afluente da margem esquerda do Rio Corumbataí & 225.057 & 7.495 .119 \\
\hline
\end{tabular}


Tabela 7. Microbacias na Bacia do Rio Corumbataí, Estado de São Paulo com predomínio de matas nativas. ID como discutido no texto. Sub-bacias: $a c=$ Alto Corumbataí, $\mathrm{pc}=$ Rio Passa-Cinco, $\mathrm{rc}=$ Ribeirão Claro e bc $=$ Baixo Corumbataí. Coordenadas em UTM, fuso 23 S, Datum Córrego Alegre

\begin{tabular}{|c|c|c|c|c|c|c|}
\hline \multirow{2}{*}{ ID } & \multirow{2}{*}{ Sub-bacia } & \multirow{2}{*}{ Município } & \multirow{2}{*}{ Localidade } & \multirow{2}{*}{ Nome do rio } & \multicolumn{2}{|c|}{ Coordenadas (m) } \\
\hline & & & & & $\mathrm{x}$ & $\mathrm{y}$ \\
\hline 20 & ac & Analândia & Fazenda da Estrela & $\begin{array}{l}\text { Tributário pela margem esquerda de } \\
\text { afluentes do Córrego Santa Terezinha }\end{array}$ & 218.892 & 7.549 .764 \\
\hline 44 & ac & Corumbataí & Fazenda Santo Urbano - Entrada & (pertence à uma bacia sem nome) & 233.646 & 7.545 .665 \\
\hline 173 & $\mathrm{pc}$ & Itirapina & Fazenda Sinimbú & $\begin{array}{l}\text { Afluente da margem direita do } \\
\text { Ribeirão Pirapitinga }\end{array}$ & 207.954 & 7.530 .196 \\
\hline 200 & $\mathrm{pc}$ & Itirapina & Fazenda Ana Conceta & $\begin{array}{l}\text { Afluente da margem esquerda do } \\
\text { Ribeirão Pirapitinga }\end{array}$ & 211.263 & 7.526 .995 \\
\hline 257 & $\mathrm{rc}$ & Rio Claro & Fazenda São José & $\begin{array}{l}\text { Afluente da margem esquerda do } \\
\text { Ribeirão Claro }\end{array}$ & 243.756 & 7.526 .334 \\
\hline 323 & $\mathrm{pc}$ & Itirapina & Bairro Passa-Cinco & $\begin{array}{l}\text { Afluente da margem direita do Rio } \\
\text { Passa-Cinco }\end{array}$ & 209.656 & 7.524 .386 \\
\hline 409 & $\mathrm{pc}$ & Ipeúna & - & Ribeirão João Pinto & 215.885 & 7.518 .710 \\
\hline 485 & $\mathrm{pc}$ & Ipeúna & - & Córrego da Lapa & 212.570 & 7.517 .764 \\
\hline 572 & $\mathrm{rc}$ & Santa Gertrudes & - & $\begin{array}{l}\text { Afluente da margem direita do Córrego } \\
\text { da Barreira }\end{array}$ & 242.810 & 7.509 .732 \\
\hline 615 & bc & Piracicaba & Bairro dos Bernardos & Córrego Pitanga & 227.149 & 7.505 .348 \\
\hline 648 & $\mathrm{bc}$ & Piracicaba & Bairro Costa Pinto & Córrego Barro Frio & 225.148 & 7.497 .315 \\
\hline
\end{tabular}


Tabela 8. Microbacias na Bacia do Rio Corumbataí, Estado de São Paulo com predomínio de pastagens. ID como discutido no texto. Sub-bacias: $\mathrm{ac}=$ Alto Corumbataí, $\mathrm{mc}=$ Médio Corumbataí, $\mathrm{ca}=$ Ribeirão da Cabeça, $\mathrm{pc}=$ Rio Passa-Cinco, rc = Ribeirão Claro e bc = Baixo Corumbataí. Coordenadas em UTM, fuso 23 S, Datum Córrego Alegre

\begin{tabular}{|c|c|c|c|c|c|c|}
\hline \multirow{2}{*}{ ID } & \multirow{2}{*}{ Bacia } & \multirow{2}{*}{ Município } & \multirow{2}{*}{ Localidade } & \multirow{2}{*}{ Nome do rio } & \multicolumn{2}{|c|}{ Coordenadas (m) } \\
\hline & & & & & $\mathrm{x}$ & $\mathrm{y}$ \\
\hline 1 & ac & Analândia & - & Córrego Nova América & 227.095 & 7.553 .444 \\
\hline 43 & ac & Analândia & - & $\begin{array}{l}\text { Afluente da margem esquerda do } \\
\text { Córrego das Taipas }\end{array}$ & 229.061 & 7.546 .381 \\
\hline 47 & ac & Corumbataí & Fazenda Santo Urbano - Sede & (pertence à uma bacia sem nome) & 233.636 & 7.544 .672 \\
\hline 59 & ac & Corumbataí & $\begin{array}{l}\text { Fazenda Vereda dos } \\
\text { Avestruzes }\end{array}$ & Córrego dos Emboabas & 230.452 & 7.543 .312 \\
\hline 60 & ac & Corumbataí & próximo à cidade & $\begin{array}{l}\text { Afluente da margem direita do Rio } \\
\text { Corumbataí }\end{array}$ & 228.240 & 7.541 .731 \\
\hline 76 & $\mathrm{rc}$ & Corumbataí & Sítio Águas Claras & Afluente do Córrego do Jacú & 240.907 & 7.538 .304 \\
\hline 87 & $\mathrm{mc}$ & Corumbataí & Fazenda Boa Vista & Córrego Boa Vista & 228.657 & 7.537 .483 \\
\hline 88 & $\mathrm{mc}$ & Corumbataí & - & $\begin{array}{l}\text { Afluente da margem direita do Córrego } \\
\text { da Cachoeirinha }\end{array}$ & 231.025 & 7.534 .709 \\
\hline 140 & $\mathrm{mc}$ & Rio Claro & Distrito de Ferraz & $\begin{array}{l}\text { Afluente da margem esquerda do } \\
\text { Córrego Batista do Ferraz }\end{array}$ & 232.363 & 7.533.847 \\
\hline 142 & $\mathrm{ca}$ & Itirapina & Bairro Itapé & $\begin{array}{l}\text { Afluente da margem esquerda do Rio da } \\
\text { Cabeça }\end{array}$ & 217.951 & 7.532 .087 \\
\hline 188 & $\mathrm{ca}$ & Rio Claro & - & Córrego Sapezeiro & 220.377 & 7.529 .369 \\
\hline 393 & $\mathrm{rc}$ & Rio Claro & Fazenda Jequitibá & Córrego Ibitinga & 243.987 & 7.520 .444 \\
\hline 403 & $\mathrm{pc}$ & Itirapina & Bairro da Cachoeira & Córrego do Anzol & 202.183 & 7.524 .105 \\
\hline 413 & $\mathrm{pc}$ & Ipeúna & Sítio Sr. Abdallah & Córrego do Rochedo & 215.151 & 7.521 .401 \\
\hline 414 & $\mathrm{pc}$ & Itirapina & Bairro Cantagalo & Córrego Cantagalo & 210.591 & 7.520 .027 \\
\hline 547 & bc & Charqueada & Bairro Boa Vista & Ribeirão Fregadoli & 214.456 & 7.511 .404 \\
\hline
\end{tabular}


Tabela 9. Microbacias na Bacia do Rio Corumbataí, Estado de São Paulo denominadas ripárias. ID como discutido no texto e legendas. Sub-bacias: $\mathrm{ac}=$ Alto Corumbataí, $\mathrm{mc}=$ Médio Corumbataí, $\mathrm{ca}=$ Ribeirão da Cabeça, e pc $=$ Rio PassaCinco. Coordenadas em UTM, fuso 23 S, Datum Córrego Alegre

\begin{tabular}{|c|c|c|c|c|c|c|}
\hline \multirow{2}{*}{ ID } & \multirow{2}{*}{ Bacia } & \multirow{2}{*}{ Município } & \multirow{2}{*}{ Localidade } & \multirow{2}{*}{ Nome do rio } & \multicolumn{2}{|c|}{ Coordenadas (m) } \\
\hline & & & & & $\mathrm{x}$ & $\mathrm{y}$ \\
\hline 2 & ac & Analândia & - & $\begin{array}{l}\text { Afluente da margem esquerda do } \\
\text { Córrego Nova América }\end{array}$ & 229.110 & 7.553.220 \\
\hline 3 & ac & Analândia & próximo à cidade & $\begin{array}{l}\text { Afluente pela margem esquerda de } \\
\text { tributário do Rio Corumbataí }\end{array}$ & 224.251 & 7.552.071 \\
\hline 8 & ac & Analândia & - & Córrego Santa Terezinha & 221.123 & 7.551 .450 \\
\hline 15 & ac & Analândia & próximo à cidade & $\begin{array}{l}\text { Tributário da margem esquerda do Rio } \\
\text { Corumbataí }\end{array}$ & 225.995 & 7.551 .627 \\
\hline 77 & $\mathrm{ca}$ & Corumbataí & - & $\begin{array}{l}\text { Afluente da margem direita do Córrego } \\
\text { do Lajeado }\end{array}$ & 225.517 & 7.536 .868 \\
\hline 137 & $\mathrm{ca}$ & Corumbataí & $\begin{array}{l}\text { Fazenda Dona Celeste ou dos } \\
\text { Italianos }\end{array}$ & $\begin{array}{l}\text { Afluente da margem direita do Ribeirão } \\
\text { da Boa Vista }\end{array}$ & 224.288 & 7.531 .925 \\
\hline 139 & $\mathrm{mc}$ & Corumbataí & Bairro Santana de Urucaia & $\begin{array}{l}\text { Afluente da margem direita do Córrego } \\
\text { Cachoeirinha }\end{array}$ & 229.851 & 7.533 .104 \\
\hline 150 & $\mathrm{mc}$ & Corumbataí & Fazenda Corumbataí & Córrego da Jacutinga & 228.081 & 7.531 .367 \\
\hline 171 & $\mathrm{ca}$ & Itirapina & Bairro Ubá & Cabeceira do Rio da Cabeça & 212.688 & 7.530 .513 \\
\hline 308 & $\mathrm{pc}$ & Itirapina & - & $\begin{array}{l}\text { Afluente da margem esquerda do Rio } \\
\text { Passa-Cinco }\end{array}$ & 212.855 & 7.524 .264 \\
\hline 315 & $\mathrm{pc}$ & Itirapina & Fazenda Paredão & $\begin{array}{l}\text { Afluente da margem esquerda do Rio } \\
\text { Passa-Cinco }\end{array}$ & 213.780 & 7.523 .554 \\
\hline 318 & $\mathrm{pc}$ & Ipeúna & - & $\begin{array}{l}\text { Afluente da margem direita do Córrego } \\
\text { Monjolo Grande }\end{array}$ & 219.045 & 7.524.247 \\
\hline 352 & $\mathrm{pc}$ & Itirapina & Fazenda Paredão & Córrego Areião da Fazenda Paredão & 212.772 & 7.523 .433 \\
\hline 508 & $\mathrm{bc}$ & Ipeúna & - & $\begin{array}{l}\text { Afluente da margem esquerda do } \\
\text { Ribeirão Água Vermelha }\end{array}$ & 216.380 & 7.513 .646 \\
\hline
\end{tabular}




\subsection{Coleta de dados}

Nas microbacias selecionadas, os dados foram coletados através de dois procedimentos gerais. No primeiro, foram realizadas análises através de um Sistema de Informações Geográficas (SIG), visando obter variáveis sobre as microbacias como unidades amostrais. No segundo, foram mensuradas características do ambiente em um segmento do riacho principal de cada uma das microbacias selecionadas por meio de trabalhos em campo. A lógica empregada é que este segmento deve ser fortemente influenciado pelas características geomorfólogicas, geológicas, bióticas etc. da microbacia definida. Neste estudo, ambas as aproximações visam relacionar os estados das variáveis explanatórias sobre as variáveis-resposta, neste caso, a riqueza e a abundância de peixes do segmento amostrado.

Microbacias podem ser definidas como pequenas porções do terreno delimitadas por divisores topográficos, de tal modo que todo escoamento superficial pelas vertentes drena para um único ponto, o vertedouro (Leopold et al., 1963). O rio a ser amostrado na microbacia é, logicamente, sempre o riacho principal, aquele que é a somatória da rede de drenagem no ponto mais à jusante dentro da bacia. Logo, o segmento amostrado foi definido como um trecho de canal desenvolvendo-se próximo ao vertedouro da microbacia.

Os segmentos escolhidos para a amostragem mediam 150 metros. Procurou-se alocar o segmento afastado de pontes em, pelo menos, 50 metros, a fim de se evitar estruturas feitas pelo homem. Também foram observados trechos com alterações óbvias, como canalizações, aterros e diques, que foram evitados. Quando a microbacia drenava diretamente em um rio de grande porte (um riacho de ordem 4, ou superior, ou um rio propriamente dito), o trecho escolhido para amostragem era, sempre que possível, localizado 200 metros à montante da confluência dos dois rios. Com isto pretendeu-se evitar a amostragem de espécies de uma fauna própria de rios maiores, embora a distância de 200 metros seja arbitrária.

Cada uma das microbacias selecionadas foi amostrada duas vezes, uma na estação seca (entre junho e setembro), outra na estação chuvosa (entre janeiro e março), 
ao longo de dois anos (2003 e 2004), em quatro campanhas consecutivas. Isto resultou em 60 amostras tomadas nas campanhas 1 e 3, na estação chuvosa, e 58 amostras tomadas nas campanhas 2 e 4 , na estação seca.

\subsubsection{Caracterização das microbacias}

Através de diversos mapas, ou planos de informação, obtidos junto ao Projeto Corumbataí (2001) e ao Atlas Ambiental da Bacia do Rio Corumbataí (CEAPLA, 2004), foram selecionadas variáveis para análises de parâmetros diversos das microbacias, determinadas ou calculadas com o uso de softwares como ArcView, Idrisi, Excel, entre outros. Estas variáveis foram listadas na Tabela 10. Um código de duas letras foi determinado para cada variável, a fim de facilitar sua identificação em análises posteriores. Esta caracterização foi realizada uma única vez, admitindo-se que os estados destas variáveis não se alteraram entre as campanhas.

A Figura 13 ilustra como foram medidas as ordenações de canais pelo método de Strahler, Shreve e ligação à jusante (downstream-link), variáveis de códigos HS, SH e DL, respectivamente. A Figura 14 ilustra a tomada da variável AJ - área de mata no buffer de 30 metros da rede de canais, 500 metros à jusante e à montante do ponto de amostragem. O índice de dominância do uso e da cobertura do solo na microbacia foi descrito como no item 3.4.2. 
Tabela 10. Variáveis utilizadas na descrição das microbacias

\begin{tabular}{|c|c|c|c|}
\hline Código & Nome & Explicação & $\begin{array}{l}\text { Base de dados para } \\
\text { mensuração }\end{array}$ \\
\hline AA & área da microbacia & área da microbacia, calculada em hectares & $\begin{array}{l}\text { modelo digital do } \\
\text { terreno (MDT) }\end{array}$ \\
\hline HS & $\begin{array}{l}\text { ordenação de } \\
\text { Strahler }\end{array}$ & $\begin{array}{l}\text { ordenação clássica, proposta por Strahler (Fitzpatrick } \\
\text { et al. 1998), Figura } 13\end{array}$ & $\begin{array}{l}\text { mapa digital da rede } \\
\text { hidrográfica }\end{array}$ \\
\hline $\mathrm{SH}$ & $\begin{array}{l}\text { ordenação de } \\
\text { Shreve }\end{array}$ & $\begin{array}{l}\text { número de nascentes à montante do ponto } \\
\text { considerado (Fitzpatrick et al. 1998), v. Figura } 13\end{array}$ & $"$ \\
\hline DL & ligação-jusante & $\begin{array}{l}\text { valor de ordenação de Shreve abaixo da primeira } \\
\text { confluência à jusante do ponto considerado (Osborne } \\
\text { \& Wiley 1996), v. Figura } 13\end{array}$ & $"$ \\
\hline DQ & $\begin{array}{l}\text { distância a um rio } \\
\text { de quarta ordem }\end{array}$ & $\begin{array}{l}\text { distância em metros entre o vertedouro da } \\
\text { microbacia e sua confluência com um rio de quarta } \\
\text { ordem }\end{array}$ & $"$ \\
\hline QC & $\begin{array}{l}\text { diferença de } \\
\text { elevação }\end{array}$ & $\begin{array}{l}\text { diferença de elevação em metros entre o vertedouro } \\
\text { da microbacia e o rio de quarta ordem mais próximo }\end{array}$ & $\begin{array}{l}\text { modelo digital do } \\
\text { terreno (MDT) }\end{array}$ \\
\hline EL & $\begin{array}{l}\text { elevação sobre o } \\
\text { nível do mar }\end{array}$ & elevação do ponto de amostragem, em metros & $"$ \\
\hline EM & elevação média & $\begin{array}{l}\text { média, em metros, da elevação de todos os pixels da } \\
\text { microbacia }\end{array}$ & $"$ \\
\hline DG & declividade geral & $\begin{array}{l}\text { declividade entre o ponto mais alto da microbacia e } \\
\text { seu vertedouro, em porcentagem }\end{array}$ & $"$ \\
\hline DD & $\begin{array}{l}\text { densidade de } \\
\text { drenagem }\end{array}$ & $\begin{array}{l}\mathrm{DD}=\text { comprimento total de todos os canais da } \\
\text { microbacia } \times \text { área da microbacia }{ }^{-1}\end{array}$ & $"$ \\
\hline $\mathrm{CI}$ & circularidade & $\mathrm{CI}=12,57 \times$ área da bacia $\times(\text { perímetro })^{-2}$ & $"$ \\
\hline OR & $\begin{array}{l}\text { orientação da } \\
\text { microbacia }\end{array}$ & $\begin{array}{l}\text { orientação do eixo formado pelo ponto mais alto da } \\
\text { microbacia e seu vertedouro, em oito ortodireções }\end{array}$ & $"$ \\
\hline $\mathrm{CD}$ & $\begin{array}{l}\text { cobertura } \\
\text { dominante }\end{array}$ & $\begin{array}{l}\text { classe do uso ou cobertura do solo dominante na área } \\
\text { da microbacia }\end{array}$ & $\begin{array}{l}\text { mapa de cobertura e } \\
\text { uso do solo }\end{array}$ \\
\hline $\mathrm{CP}$ & $\begin{array}{l}\text { porcentagem da } \\
\text { cobertura } \\
\text { dominante }\end{array}$ & $\begin{array}{l}\text { valor percentual da cobertura ou uso do solo } \\
\text { dominante }\end{array}$ & " \\
\hline DC & $\begin{array}{l}\text { índice de } \\
\text { dominância }\end{array}$ & $\begin{array}{l}\text { índice de dominância de Simpson das coberturas } \\
\text { percentuais presentes na microbacia }\end{array}$ & $"$ \\
\hline $\mathrm{UC}$ & cana & porcentagem de canaviais recobrindo a microbacia & " \\
\hline UP & pasto & porcentagem de pastagens recobrindo a microbacia & $"$ \\
\hline UE & plantada & $\begin{array}{l}\text { porcentagem de florestas plantadas (Pinus spp. e } \\
\text { Eucalyptus spp.) na microbacia }\end{array}$ & $"$ \\
\hline UM & nativa & porcentagem de matas nativas na microbacia & $"$ \\
\hline
\end{tabular}


Tabela 10. Variáveis utilizadas na descrição das microbacias

\begin{tabular}{|c|c|c|c|}
\hline Código & Nome & Explicação & $\begin{array}{l}\text { Base de dados para } \\
\text { mensuração }\end{array}$ \\
\hline UF & fruticultura & $\begin{array}{l}\text { porcentagem de culturas perenes presentes na área } \\
\text { da microbacia }\end{array}$ & $"$ \\
\hline UA & anual & porcentagem de culturas anuais na microbacia & $"$ \\
\hline UI & mineração & porcentagem em área de minerações na microbacia & $"$ \\
\hline UR & rede hidrográfica & porcentagem em área da rede hidrográfica & $"$ \\
\hline UV & malha viária & porcentagem em área da malha viária na microbacia & $"$ \\
\hline UU & área urbana & porcentagem de área urbana na microbacia & $"$ \\
\hline AJ & $\begin{array}{l}\text { área de mata à } \\
\text { jusante e à montante }\end{array}$ & $\begin{array}{l}\text { área (percentual) de mata no buffer de } 30 \text { metros, } \\
500 \text { metros à jusante e à montante do ponto de } \\
\text { amostragem, v. Figura } 14\end{array}$ & $\begin{array}{l}\text { mapa de cobertura e } \\
\text { uso do solo }\end{array}$ \\
\hline AM & $\begin{array}{l}\text { área de mata da sub- } \\
\text { bacia }\end{array}$ & $\begin{array}{l}\text { área (percentual) de mata da sub-bacia (tal como na } \\
\text { Tabela 3) na qual a microbacia está inserida }\end{array}$ & " \\
\hline DB & $\begin{array}{l}\text { cobertura vegetal } \\
\text { dominante na APP }\end{array}$ & $\begin{array}{l}\text { classe do uso ou cobertura do solo dominante na área } \\
\text { de preservação permanente (APP) dos canais da } \\
\text { microbacia }\end{array}$ & $\begin{array}{l}\text { mapa de uso e } \\
\text { cobertura e mapa de } \\
\text { limites do buffer }\end{array}$ \\
\hline ER & $\begin{array}{l}\text { embasamento } \\
\text { rochoso dominante }\end{array}$ & classe dominante de rocha-matriz na microbacia & $\begin{array}{l}\text { mapa geológico } \\
\text { digital }\end{array}$ \\
\hline $\mathrm{TS}$ & $\begin{array}{l}\text { tipo de solo } \\
\text { dominante }\end{array}$ & classe dominante de tipo de solo na microbacia & mapa de solos digital \\
\hline
\end{tabular}


A. Ordenação de riachos pelo método de Strahler

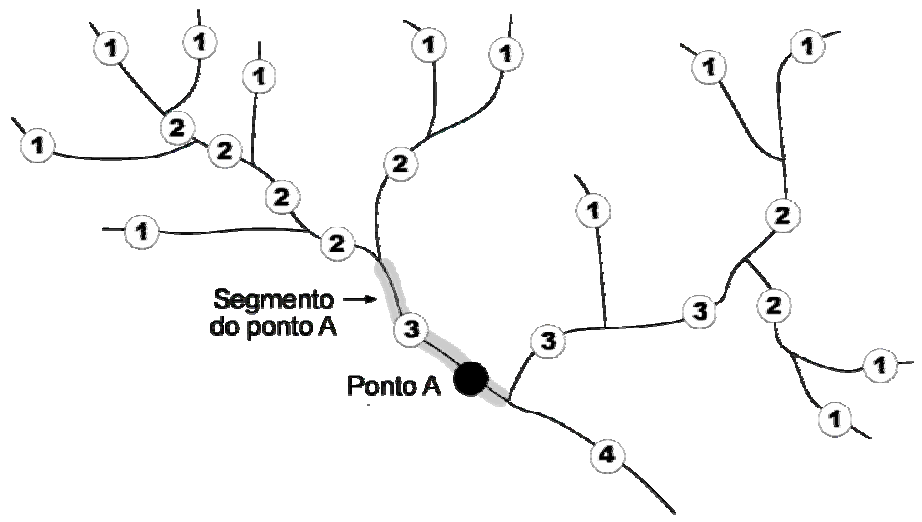

Exemplo: Ordenaçäo de Strahler para o segmento do ponto A é 3

B. Ordenação de riachos pelo método de Shreve

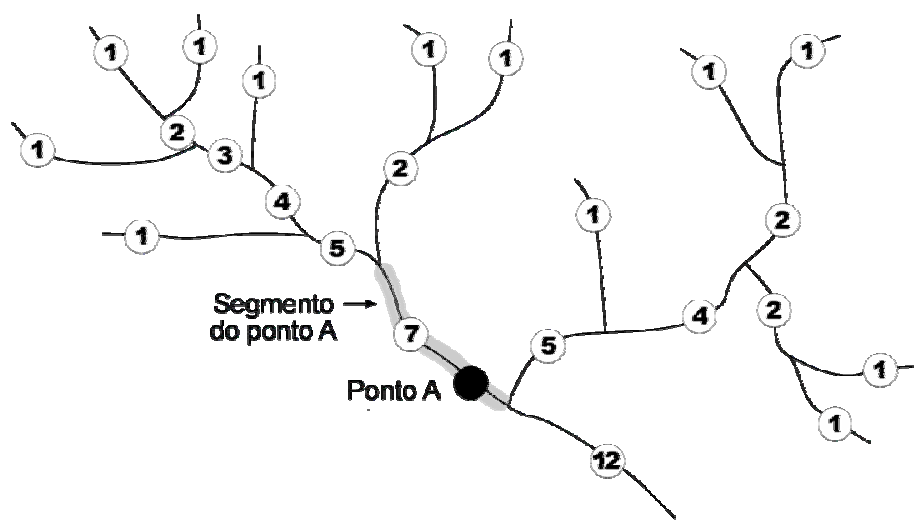

Exemplo: Ordenaçăo de Shreve para o segmento

do ponto A é 7. Ligaçăo à jusante para o ponto A é igual a 12.

Figura 13 - Diagrama esquemático ilustrando como se mede a ordenação dos canais pelo método de Strahler (A) e pelo método de Shreve e a ligação-à-jusante (B). Baseado em Fitzpatrick et al. (1998) 


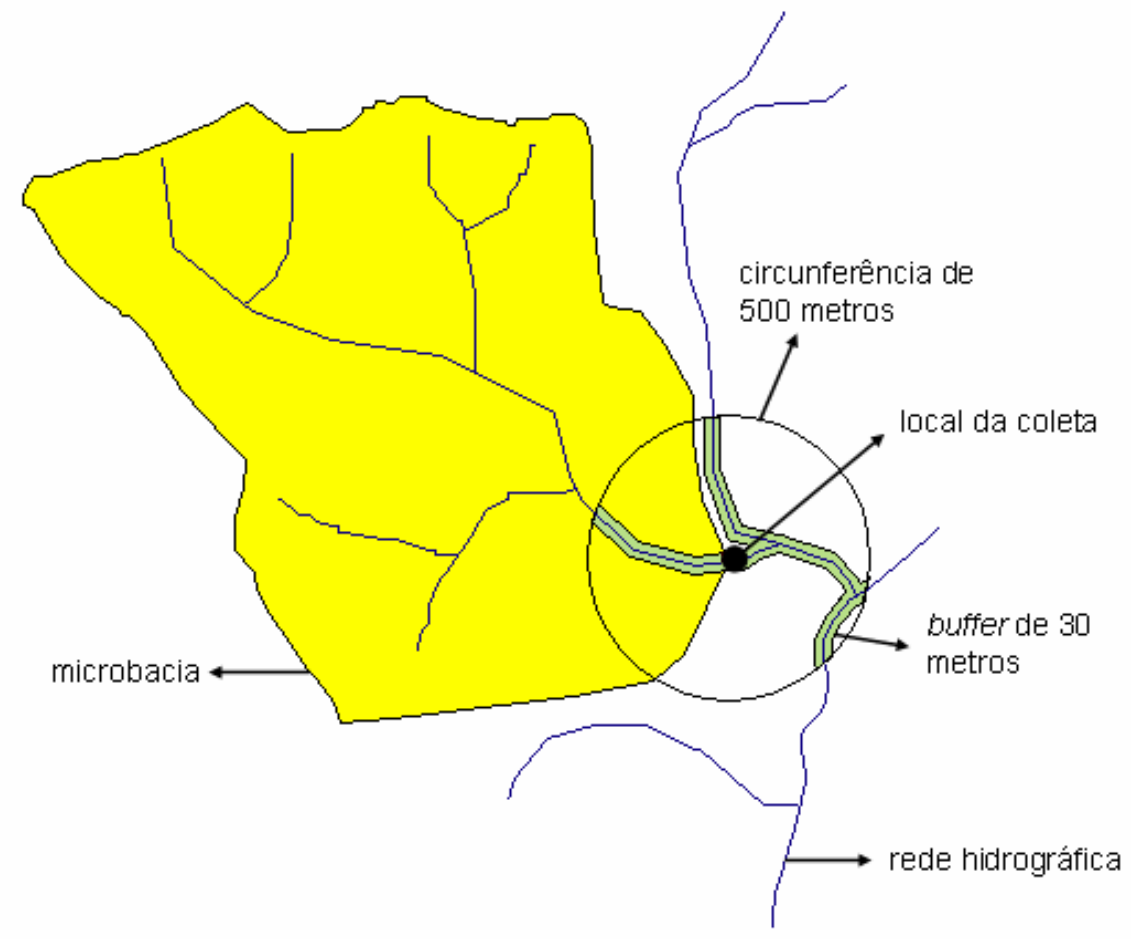

Figura 14 - Diagrama esquemático ilustrando o método de medida da variável AJ (Tabela 10). É ilustrada uma microbacia qualquer, destacando-se, em seu vertedouro, o ponto de amostragem. Uma circunferência de raio 500 metros foi definida, dentro da qual foi criado um buffer de 30 metros de largura a partir de ambas as margens dos canais ao longo da rede de drenagem contida nesta circunferência

\subsubsection{Caracterização do segmento de amostragem dos peixes}

Diversos métodos foram empregados para caracterizar o trecho de amostragem dos peixes e seus arredores. Esta foi uma necessidade óbvia neste estudo, pois fatores locais podem ser tão ou mais importantes na determinação da composição e da estrutura da ictiofauna local do que as características do entorno do canal em questão. Assim, é necessário buscar uma distinção entre estes níveis de análise. A constatação de que os riachos ocorrem em grande variedade de situações, determinados por condicionantes geomorfológicas, geológicas, antrópicas etc., são uma justificativa para a realização desta caracterização. 
Assim, a "caracterização do habitat" - relativo ao segmento de amostragem dos peixes - visa ao levantamento de variáveis relativas a três grupos principais: parâmetros físicos e químicos da água, física do canal e aspecto da vegetação ripária.

\section{Caracterização física e química da água}

No local, foram analisadas a concentração de oxigênio dissolvido e a temperatura da água com o oxímetro de marca YSI, modelo 95. Cinco medições foram realizadas em cada ocasião de amostragem, sendo anotados o tipo de habitat, a profundidade e a velocidade aproximada nos locais das medições. Próximo ao final das atividades de coleta, durante a tarde, dois litros de água foram coletados, resfriados e enviados para o Laboratório de Ecologia Aplicada, do Departamento de Ciências Florestais da ESALQ/USP para análise. Na Tabela 11 são detalhadas as variáveis amostradas, relativas aos parâmetros físicos e químicos da água.

A temperatura do ar, por ocasião das amostragens, foi anotada de um termômetro de mercúrio, sempre próximo ao meio-dia (entre 11:00 h e 13:00 h).

Tabela 11. Variáveis de parâmetros físicos e químicos da água amostras no momento de captura dos peixes. Procedimentos de análise segundo American Public Health Association (1975), exceto quanto ao oxigênio, saturação de $\mathrm{O}_{2}$ e T

\begin{tabular}{clll}
\hline Código & Nome & Unidade & Método de mensuração \\
\hline AT & alcalinidade total & $\mathrm{mg} \cdot \mathrm{l}^{-1}$ & titulométrico \\
$\mathrm{NN}$ & nitrogênio amoniacal $\left(\mathrm{N}^{\left.-\mathrm{NH}_{3}\right)}\right.$ & $\mathrm{mg} \cdot \mathrm{l}^{-1}$ & destilação e titulação \\
$\mathrm{NI}$ & nitrato & $\mathrm{mg} \cdot \mathrm{l}^{-1}$ & colorimétrico (brucina) \\
$\mathrm{PT}$ & fósforo total & $\mathrm{mg} \cdot \mathrm{l}^{-1}$ & colorimétrico \\
$\mathrm{KA}$ & potássio total & $\mathrm{mg} \cdot \mathrm{l}^{-1}$ & espectrofotométrico \\
$\mathrm{CA}$ & cálcio total & $\mathrm{mg} \cdot \mathrm{l}^{-1}$ & espectrofotométrico \\
$\mathrm{MG}$ & magnésio total & $\mathrm{mg} \cdot \mathrm{l}^{-1}$ & espectrofotométrico \\
$\mathrm{SE}$ & sedimentos em suspensão totais & $\mathrm{mg} \cdot \mathrm{l}^{-1}$ & filtração e pesagem \\
$\mathrm{AZ}$ & acidez total & $\mathrm{mg} \cdot \mathrm{l}^{-1}$ & titulométrico \\
$\mathrm{DU}$ & dureza & $\mathrm{mg} \cdot \mathrm{l}^{-1}$ & cálculo $(\mathrm{Ca}$ e Mg)
\end{tabular}


Tabela 11. Variáveis de parâmetros físicos e químicos da água amostras no momento de captura dos peixes. Procedimentos de análise segundo American Public Health Association (1975), exceto quanto ao oxigênio, saturação de $\mathrm{O}_{2}$ e T

\begin{tabular}{clll}
\hline Código & Nome & Unidade & Método de mensuração \\
\hline $\mathrm{CO}$ & gás carbônico & $\mathrm{mg} \cdot \mathrm{l}^{-1}$ & cálculo baseado em AT \\
$\mathrm{CR}$ & cor aparente & $\mathrm{PtCo}$ & colorimétrico $-\mathrm{DR} 2000$ \\
$\mathrm{TU}$ & turbidez & $\mathrm{FTU}$ & colorimétrico $-\mathrm{DR} 2000$ \\
$\mathrm{CN}$ & condutividade & $\mathrm{mS} . \mathrm{cm}^{-1}$ & condutivimétrico \\
$\mathrm{pH}$ & potencial hidrogeniônico & - & potenciométrico \\
$\mathrm{OD}$ & oxigênio dissolvido & $\mathrm{mg} \cdot \mathrm{l}^{-1}$ & oxímetro, em campo \\
$\mathrm{SA}$ & saturação de oxigênio & $\%$ & oxímetro, em campo \\
$\mathrm{TG}$ & temperatura & ${ }^{\circ} \mathrm{C}$ & oxímetro, em campo \\
\hline
\end{tabular}

Caracterização física do canal no trecho de amostragem dos peixes

Antes de qualquer atividade de caracterização de habitat (v. item a seguir), o trecho a ser amostrado era fechado em suas extremidades com redes de náilon trançado de abertura de $6 \mathrm{~mm}$ entre nós opostos. Duas redes eram colocadas à jusante, numa distância não superior a 1,5 metro entre si, e uma 150 metros à montante. $\mathrm{O}$ trecho era delimitado com três guias de 50 metros cada, marcadas a cada metro.

$\mathrm{Na}$ maior parte destas mensurações foram utilizadas planilhas de apoio (Anexo B), utilizando-se, nelas, as definições das categorias de tamanhos de partículas (adaptada da escala de Wentworth, Cummins, 1962; Tabela 12), velocidades da superfície da água (adaptado de Bisson \& Montgomery, 1996; Tabela 13) e tipos de unidades de habitat (p. ex., Fitzpatrick et al., 1998; Tabela 14). Isto visou à uniformização das estimativas entre os pesquisadores envolvidos e a constância das estimativas entre as diferentes ocasiões de amostragem.

Esta caracterização foi realizada empregando-se três métodos distintos: observações diretas sobre seqüência e tamanho de habitats, estruturas internas do canal e das margens, transecções regulares ao longo do trecho amostrado de 150 metros, e lançamentos de quadrado para análise de substrato. 
Tabela 12. Categorias ou classes de substrato e seus tamanhos (maior eixo), em milímetros. Simplificado da escala de Wentworth, de acordo com Cummins (1962)

\begin{tabular}{lc}
\hline Categoria & Tamanho $(\mathrm{mm})$ \\
\hline bloco & $>256$ \\
matacão & entre 256 e 64 \\
seixo & entre 64 e 16 \\
cascalho & entre 16 e 2 \\
areia & entre 2 e 0,6 \\
silte e argila & $<0,6$ \\
\hline
\end{tabular}

Além destas partículas, durante a coleta de dados eram considerados como substratos possíveis: rocha matriz ("lajes" constituindo leito ou barrancas do rio), troncos (maiores que $8 \mathrm{~cm}$ de circunferência), matéria orgânica (resíduos orgânicos vegetais) e outros (telhas, tijolos, sacos plásticos e lixo em geral).

Tabela 13. Categorias de velocidade da água na superfície, modificadas de Bisson \& Montgomery (1996)

\begin{tabular}{cl}
\hline Categoria & Critério \\
\hline 0 & movimento imperceptível, praticamente estagnada \\
1 & movimento perceptível, porém sem alterações na superfície \\
2 & superfície alterada, mas pouca ondulação, menor que $0,5 \mathrm{~cm}$ \\
3 & superfície bastante alterada, maior que $0,5 \mathrm{~cm}$ \\
4 & água revolta, branca, com bolhas de ar, mesmo fora de saltos \\
\hline
\end{tabular}


Tabela 14. Tipos de unidades de habitat, adaptado de Fitzpatrick et al. (1998)

\begin{tabular}{ll}
\hline Tipo & Descrição \\
\hline $\begin{array}{l}\text { Corredeir } \\
\text { a }\end{array}$ & $\begin{array}{l}\text { Fluxo predominante no sentido montante-jusante, superfície da água alterada, } \\
\text { ondulada, com velocidades entre } 2 \text { e } 4 \text {, profundidade rasa. Unidade de } \\
\text { predomínio de erosão do leito. }\end{array}$ \\
Run & $\begin{array}{l}\text { Fluxo predominante no sentido montante-jusante, porém superfície da água } \\
\text { pouco alterada, velocidade } 1 \text { ou, no máximo, 2. Largura relativamente }\end{array}$ \\
& $\begin{array}{l}\text { homogênea e desenvolvimento retilíneo. Têm profundidade intermediária entre } \\
\text { os poços e as corredeiras. Unidade de predomínio de transporte de materiais. }\end{array}$ \\
Poço & $\begin{array}{l}\text { Extensas áreas de refluxo no sentido jusante-montante, superfície da água pouco } \\
\text { ou medianamente alterada, com velocidade entre 0 e 3, na média. São, por } \\
\text { definição profundos em relação às corredeiras e aos run. Unidade de predomínio } \\
\text { de sedimentação. }\end{array}$ \\
\hline
\end{tabular}

Nas observações diretas sobre o habitat, anotou-se a seqüência de unidades de habitat presentes no trecho a ser amostrado, utilizando-se de guias dispostas ao longo das margens do riacho. As unidades de habitat foram diferenciadas como na Tabela 14. Por definição, a unidade de habitat tem mais do que a largura média estimada do canal (Sedell et al., 1990; Bisson \& Montgomery, 1996). Desta forma, sub-unidades de habitat, como pequenos remansos laterais, foram mencionados como corredeiras complexas, run complexos etc., mas não diferenciados nas análises. Determinado o tipo de habitat, estimava-se sua área em metros quadrados, detectava-se a presença de troncos e/ou galhadas, vegetação pendente tocando ou imergindo na água, pacotes de folhas, estimando as áreas em metros quadrados. Estruturas como saltos ou "tranqueiras" foram destacadas, podendo ser estimada sua altura ou área. Também foram anotadas a presença de barrancos definidos e a presença de abrigos evidentes nestes barrancos (undercut banks, Fitzpatrick et al., 1998), o sombreamento na unidade (aproximado para $10 \%$ e a velocidade média da água na unidade. Em condições de águas muito turvas, algumas destas estimativas foram prejudicadas, o que foi anotado.

As transecções regulares foram feitas em intervalos de quatro metros, no sentido jusante-montante. Cerca de trinta e oito transecções foram realizadas em cada trecho de 150 metros de extensão. Em cada uma destas transecções, tomaram-se medidas de 
largura do canal (aproximada para $5 \mathrm{~cm}$ ) perpendiculares ao maior desenvolvimento do canal naquela transecção. Então, a partir da margem onde estava disposta a guia, mediuse a profundidade em centímetros (aproximada para a unidade), classificou-se o tipo de substrato, estimou-se a velocidade superficial da água, e a direção do fluxo da água na superfície, relativo ao desenvolvimento geral do canal naquela transecção e aproximado para os 90 graus mais próximos (entre $0^{\circ}, 90^{\circ}$ ou $180^{\circ}$ para o fluxo no sentido montantejusante, divergente para os lados ou refluxo, respectivamente).

Cada grupo destas quatro determinações (profundidade, substrato, velocidade e direção de fluxo) foi tomado a intervalos que variavam em relação à largura do canal naquela transecção. Estes intervalos foram definidos arbitrariamente em $30 \mathrm{~cm}$ para larguras entre $60 \mathrm{~cm}$ e $210 \mathrm{~cm}, 50 \mathrm{~cm}$ para larguras entre $210 \mathrm{~cm}$ e $350 \mathrm{~cm}$ e um metro para larguras maiores que $350 \mathrm{~cm}$. Em trechos mais estreitos que $60 \mathrm{~cm}$, tomou-se as medidas no centro do canal. Canais bifurcados por "ilhas" foram medidos independentemente, mas a distância entre eles foi anotada. O espaçamento entre as medidas foi realizado visando obter-se por volta de 120-150 determinações. Simonson et al. (1994) notam que apenas 20 transecções espaçadas entre si pelo dobro da largura média do trecho estudado, em canais cuja média é menor do que cinco metros, representam bem o universo de variação dos parâmetros mensurados, provavelmente com alguma relevância biológica. Estas medidas também foram tomadas pelo autor do documento, e repassadas para um anotador locado na margem do riacho.

Os lançamentos de quadrado foram realizados com um quadrado construído de tubos de PVC perfurados, de lado igual a $50 \mathrm{~cm}$. Trinta lançamentos foram realizados ao longo dos 150 metros delimitados para a captura dos peixes. O local onde seria lançado o quadrado foi determinado por uma lista de números randômicos gerados pelo programa Excel (Microsoft), entre 0 e 150, determinando a posição longitudinal do lançamento, e entre 0 e 2, determinando a posição lateral do lançamento, entre próximo à margem esquerda, centro ou próximo à margem direita do canal. Feito o lançamento, $o$ amostrador determinava visualmente as porcentagens (aproximadas para $5 \%$ ) de composição do substrato, utilizando-se da mesma escala de tamanho de partículas citadas anteriormente. Quando não havia possibilidade de visualização do leito do canal, 
a amostragem era feita por tato. $\mathrm{O}$ objetivo deste método foi o de determinar a composição percentual do substrato presente no trecho amostrado.

Diversas variáveis foram calculadas a partir dos conjuntos de dados obtidos das formas descritas, tendo sido usadas fórmulas padrão de estatística descritiva, como média, moda e variância. Quanto ao índice de diversidade calculado para o substrato, utilizou-se a recíproca do índice de Simpson $\left(D_{R}\right)$, um índice de dominância que enfatiza os itens mais comuns em uma amostra, e pode ser calculado pela fórmula:

$$
D_{R}=1-\sum\left\{\left[n_{i}\left(n_{i}-1\right)\right] \times[N(N-1)]^{-1}\right\},
$$

Onde $n_{i}$ é o número de elementos da categoria $i$ na amostra contendo um número total de elementos igual a $N$ (Magurran, 1988).

\section{Caracterização do entorno do canal no trecho de amostragem dos peixes}

Quanto ao desenvolvimento do canal, foram avaliados a largura média do leito maior do rio (Christofoletti, 1981, ou o bankfull width citado em Fitzpatrick et al., 1998) e o aprofundamento do leito na planície de inundação. As variáveis foram medidas com auxílio de trena e uma estaca graduada, tomando-se seis medidas espaçadas entre si por 25 metros, perpendiculares ao desenvolvimento geral do canal. Nestas transecções, procurou-se a altura entre o topo da barranca e o ponto de talvegue no leito do riacho. Logicamente, estas medidas foram tomadas apenas em canais não confinados, que apresentavam planícies de inundação bem definidas.

O desnível total do segmento amostrado foi mensurado com um nível de bolha com uma mangueira de 30 metros de comprimento. $\mathrm{O}$ valor foi expresso em porcentagem, isto é, dividindo-se o desnível total do segmento pelo comprimento amostrado (150 metros) e multiplicando o resultado por 100 .

Outras três variáveis foram consideradas: número de árvores pendentes sobre o canal, tipo de vegetação ripária em transecções de 30 metros em ambas as margens, perpendicular ao desenvolvimento do canal, e insolação média incidente sobre o canal. A primeira variável foi medida contando-se a quantidade de árvores com ao menos parte 
dos ramos projetando-se sobre a superfície do canal, independentemente da altura e distância do canal. Foram consideradas árvores maiores que oito centímetros de circunferência na altura do peito e também cipós lenhosos e pteridófitas. Uma vez que a entrada de material lenhoso no canal é forte condicionador de unidades e sub-unidades de habitats em um riacho, tornou-se interessante mensurar esta interação entre vegetação ripária e estrutura física do ambiente fluvial.

Em outra série de medições, estimou-se o tipo de vegetação ripária em transecções de 30 metros em ambas margens do riacho, perpendiculares ao desenvolvimento principal do canal (Anexo B). As estimativas foram tomadas a cada 15 metros, tomando-se como referência a guia marcada ao longo do canal. A vegetação foi determinada entre: 1 - pastagem, 2 - pasto sujo (até 1,5 m de altura), 3 - capoeira (predomínio em cobertura do estrato herbáceo), 4 - secundária inicial (predomínio do estrato arbóreo-arbustivo $>6$ metros), 5 - secundária tardia (domínio do estrato arbóreo $>10$ metros de altura). Distinguiu-se entre pasto limpo e sujo pelo grau de manejo que era empregado ao terreno, sendo que, no último, pouco ou nenhum manejo ocorria. Novamente optou-se por trabalhar com 30 metros de extensão, pois esta é a distância sugerida pela legislação ambiental brasileira sobre as áreas destinadas à preservação permanente ao longo de rios de pequeno porte. Esta caracterização é importante pois a legenda do mapa do uso do solo não leva em conta as diferente fisionomias de matas e também de pastagens, nem, tampouco, detecta faixas de vegetação mais estreitas que 20 metros.

A luminosidade incidente no canal foi medida utilizando-se um luxímetro ICEL de 200.000 lux, e resolução de 1 lux. Foram tomadas medidas a cada 5 metros ao longo dos 150 metros de amostragem dos riachos, e uma medida a pleno sol para referência. As medições foram realizadas sempre entre 11:00 h e 13:00 h. Foram anotadas as condições de recobrimento do céu por nuvens, ou a presença de névoa. O objetivo destas medições foi o de apresentar o sombreamento dos canais como variável aleatória contínua, e não discreta, como descrito acima. Esta variável foi mensurada somente na terceira e quarta campanha de coleta.

A Tabela 15 mostra as variáveis descritivas derivadas dos dados obtidos através 
dos métodos descritos acima, separadas em três grupos. O primeiro grupo de variáveis diz respeito às barrancas ou ao entorno do canal; o segundo grupo são métricas derivadas de inspeção visual dos habitats. O terceiro e último grupo são variáveis derivadas de medidas tomadas das transecções ou lançamentos de quadrado.

As medidas detalhadas neste item foram tomadas pelo autor deste documento, a não ser pelos lançamentos do quadrado, medições de oxigênio dissolvido da água e luminosidade com luxímetro.

As tabelas contendo os valores mensurados ou derivados das medições de cada uma das variáveis detalhadas acima para as 60 microbacias foram colocadas no Anexo D. 
Tabela 15. Variáveis derivadas dos métodos de mensuração de variáveis do canal, barrancas e entorno

\begin{tabular}{|c|c|c|c|}
\hline Código & Nome e/ou explicação & Unidade & Método de medida \\
\hline NU & número de unidades de habitat & unidades & estimativa visual \\
\hline $\mathrm{PC}$ & $\begin{array}{l}\text { relação: } \mathrm{n}^{\mathrm{o}} \text { poços } \times\left(\mathrm{n}^{\mathrm{o}} \text { corredeiras }+\mathrm{n}^{\mathrm{o}} \text { run }\right)^{-1} \\
\text { (unidade/unidade) }\end{array}$ & adimensional & derivada de estimativa visual \\
\hline $\mathrm{RP}$ & $\begin{array}{l}\text { relação: área de poços } \times \text { (área de corredeiras + } \\
\text { áreas de run })^{-1} \text { (área/área) }\end{array}$ & $\mathrm{m}^{2} \cdot \mathrm{m}^{-2}$ & derivada de estimativa visual \\
\hline QT & área total de troncos submersos & $\mathrm{m}^{2}$ & estimativa visual \\
\hline $\mathrm{VE}$ & área total de vegetação pendente & $\mathrm{m}^{2}$ & estimativa visual \\
\hline $\mathrm{PF}$ & área total de pacotes de materiais orgânicos & $\mathrm{m}^{2}$ & estimativa visual \\
\hline UB & $\begin{array}{l}\text { porcentagem de unidades com abrigos nos } \\
\text { barrancos }\end{array}$ & unidades & contagem direta \\
\hline VM & $\begin{array}{l}\text { velocidade média a partir das estimativas por } \\
\text { unidade }\end{array}$ & adimensional & estimativa visual \\
\hline LM & largura média de canal & $\mathrm{cm}$ & trena ou estaca graduada \\
\hline $\mathrm{PM}$ & profundidade média do canal & $\mathrm{cm}$ & metro \\
\hline VP & variância da profundidade de canal & $\mathrm{cm}$ & derivada de medições com metro \\
\hline $\mathrm{AC}$ & área do canal (Bisson e Montgomery, 1996) & $\mathrm{m}^{2}$ & derivada de medições com metro \\
\hline $\mathrm{VC}$ & volume do canal (idem) & $\mathrm{m}^{3}$ & derivada de medições com metro \\
\hline DS & índice de diversidade de substrato & adimensional & derivada de medições diretas \\
\hline MS & moda do substrato (substrato mais freqüente) & adimensional & estimativa visual \\
\hline PA & porcentagem de areia & $\%$ & derivada de medições diretas \\
\hline $\mathrm{OV}$ & moda de velocidade & adimensional & estimativa visual \\
\hline MV & média de velocidade & adimensional & estimativa visual \\
\hline VV & variância da velocidade & adimensional & derivada de estimativa visual \\
\hline PU & proporção de fluxos diferentes de 0 & adimensional & derivada de estimativa visual \\
\hline $\mathrm{BM}$ & largura média das barrancas máximas & $\mathrm{m}$ & trena \\
\hline $\mathrm{AB}$ & altura média de barrancas & $\mathrm{m}$ & estaca graduada \\
\hline DR & declividade geral do trecho de 150 metros & adimensional & nível de mangueira \\
\hline $\mathrm{CV}$ & cobertura vegetal dominante no entorno & adimensional & estimativa visual \\
\hline AP & número de árvores pendentes & árvores & contagem direta \\
\hline $\mathrm{SO}$ & sombreamento médio do canal & $\%$ & estimativa visual \\
\hline IS & insolação média incidente & $\operatorname{lux}$ & luxímetro \\
\hline
\end{tabular}




\subsubsection{Coleta dos peixes}

A eletropesca foi o método de captura empregado neste trabalho em todas as ocasiões. O protocolo de captura seguiu o método de depleção (Seber, 1982), tendo sido utilizadas três "passagens" consecutivas de esforços iguais, um dos pressupostos do método de depleção.

O aparelho de eletropesca utilizado era constituído de um gerador Honda EM 1000F de $1000 \mathrm{~W}$ de potência, dois cabos monofásicos de $4 \mathrm{~mm}$ e $100 \mathrm{~m}$ de extensão e, na ponta destes, os terminais, constituídos de um puçá e uma "grade" metálica de formato retangular. O puçá possuía malha de náilon trançado de $2 \mathrm{~mm}$ entre nós opostos. O sistema era operado em corrente alternada (AC), na freqüência de $60 \mathrm{~Hz}$.

Após toda caracterização de habitat detalhada acima, a equipe decidia se era necessário limpar o trecho a ser amostrado de troncos, galhos pendentes e acúmulos de folhas, a fim de facilitar o trânsito da equipe de eletropesca e aumentar as probabilidades de captura em determinados trechos. Este procedimento pode ter modificado a estrutura de alguns canais de modo significativo no trecho amostrado, o que pode ter acarretado em uma diminuição da complexidade de habitat, com conseqüentes alterações na estrutura das comunidades de peixes, em uma questão de semestres. Esta questão foi abordada no item 4.6.

A equipe de eletropesca era constituída de dois operadores, que portavam os terminais, e dois coletores, que recebiam o material acumulado no puçá em bandejas plásticas. Este folhiço era rapidamente triado pelos coletores ao longo do trecho de captura, que separavam os peixes capturados. Um quinto elemento podia, eventualmente, auxiliar nessa triagem, ou no desembaraço dos cabos elétricos. As "passagens" da equipe de eletropesca davam-se no sentido montante - jusante, durando entre $1: 15 \mathrm{~h}$ a $25 \mathrm{~min}$ cada, tempo que variava de um riacho a outro. Ao final de cada passagem, a rede mais à montante da porção inferior do trecho era retirada e os peixes nela capturados eram recolhidos. Todos os exemplares capturados eram colocados em um recipiente contendo formol à $10 \%$. O processo era repetido em cada uma das três passagens. Ao final da terceira passagem a rede mais à jusante era checada e os peixes nela retidos sacrificados em um quarto recipiente identificado. 
Posteriormente, no retorno ao laboratório, exemplares maiores que $50 \mathrm{~mm}$ de comprimento padrão eram injetados com formol à $10 \%$. Os peixes eram transferidos para sacos plásticos devidamente identificados, armazenados por 2-5 dias em formol à $10 \%$, e transferidos para barris contendo etanol à $70 \%$.

\subsubsection{Variáveis-resposta}

A principal variável testada foi o número de espécies. Estas foram identificadas com base no conhecimento prévio do autor deste trabalho, além de trabalhos publicados na literatura versando sobre a sistemática de peixes de água doce, especialmente da Bacia do Rio Tietê. Esta identificação foi posteriormente confirmada por especialistas da Seção de Peixes do Museu de Zoologia da Universidade de São Paulo (MZUSP) e da Universidade Estadual de Maringá (UEM-Nupélia), onde foram depositadas espécies de referência.

A partir da identificação das espécies foram definidas outras variáveis, listadas na Tabela 16 e descritas a seguir.

Tabela 16. Variáveis obtidas das amostras de peixes de riachos da Bacia do Rio Corumbataí, Estado de São Paulo

\begin{tabular}{ll}
\hline Código & Explicação \\
\hline$S$ & número total de espécies da amostra \\
$F$ & número total de famílias da amostra \\
$N$ & número total de indivíduos da amostra \\
$H^{\prime}$ & índice de diversidade de Shannon \\
$E_{H}$ & índice de eqüitatividade de Shannon \\
$D_{R}$ & recíproca do índice de diversidade de Simpson \\
$B T$ & biomassa total da amostra \\
$G T$ & número de grupos tróficos presentes na amostra \\
\hline
\end{tabular}

Os índices de diversidade foram escolhidos com base nas recomendações de Washington (1982), Magurran (1988) e Krebs (1999), e visam enfatizar diferentes 
aspectos da estrutura da comunidade amostrada, sejam elas riqueza de espécies $\left(H^{\prime}\right)$, dominância $\left(D_{R}\right)$ ou a eqüitatividade entre as espécies $\left(E_{H^{\prime}}\right)$.

O índice de Shannon foi calculado pela fórmula:

$$
H^{\prime}=-\sum\left(p_{i} \times \ln p_{i}\right)
$$

Onde $H^{\prime}$ é o índice de diversidade de Shannon e $p_{i}$ a proporção da espécie $i$ na amostra.

O índice de eqüitatividade de Shannon é derivado de $H^{\prime}$ pela expressão:

$$
E_{H}=H^{\prime} \times \ln S,
$$

Onde $E_{H}$ é o índice de eqüitatividade de Shannon e $S$ o número de espécies da amostra.

A recíproca do índice de Simpson foi calculada baseada na fórmula deste índice (citada no item 3.4.2), subtraindo-se o valor obtido da unidade.

As espécies foram agrupadas em categorias de uso de recursos alimentares, baseando-se principalmente no trabalho de Sawakuchi et al. ${ }^{1}$, que utilizou as mesmas amostras obtidas no presente estudo. Apenas no caso de espécies não estudadas por estes autores, recorreu-se a outras fontes. Neste trabalho, os autores compuseram amostras com indivíduos oriundos de diversos riachos, a fim de representar a máxima amplitude de utilização de recursos alimentares pela espécie. Deste modo, buscou-se reduzir os possíveis efeitos de um dado riacho fornecer a uma espécie recursos atípicos, dentro do universo de riachos considerados. Isto evitou a representação das espécies como mais especializadas do que são, já que a adaptabilidade trófica ocorre amplamente nos peixes (Gerking, 1994). Assim, este trabalho (Sawakuchi et al., op. cit.) visou

\footnotetext{
${ }^{1}$ Sawakuchi, H.O.; Ferreira, A.; Gerhard, P. Hábitos alimentares das espécies de peixes de riacho da bacia do Rio Corumbataí, SP. (em elaboração).
} 
estabelecer hábitos alimentares amplos, em uma gama variada de situações ambientais. É um procedimento diverso do adotado em trabalhos que focam um ou poucos riachos, como em Costa (1987), Castro \& Casatti (1997), Casatti \& Castro (1998), Vilella et al. (2001), entre outros.

O resultado das análises de freqüência de ocorrência de itens alimentares nos conjuntos de estômagos das espécies estudadas por Sawakuchi et al. (op. cit.) foram inspecionados e, por similaridade, definiu-se seis categorias tróficas, descritas na Tabela 17.

Tabela 17. Grupos tróficos e sua diagnose, conforme Sawakuchi et al.

\begin{tabular}{ll}
\hline Grupo trófico & Diagnóstico \\
\hline detritívoro-algívoro & $\begin{array}{l}\text { Dieta composta em grande parte por algas, associadas a detrito e/ou sedimento, } \\
\text { além de insetos aquáticos com freqüência elevada }\end{array}$ \\
detritívoro-iliófago & $\begin{array}{l}\text { Composição da dieta similar a dos detritívoro-algívoros, porém, os insetos } \\
\text { aquáticos são menos importantes, ocorrendo, com maior freqüência, anelídeos. } \\
\text { Tipicamente, são as espécies que se alimentam de lodo, isto é, material } \\
\text { orgânico finamente particulado }\end{array}$ \\
& $\begin{array}{l}\text { As espécies deste grupo consomem insetos aquáticos e crustáceos com } \\
\text { freqüência elevada, além de algas associadas com sedimentos e/ou detritos. São } \\
\text { freqüentes os anelídeos } \\
\text { bentófago }\end{array}$ \\
Dieta composta por variedade de itens de origem animal e vegetal, alóctone e \\
autóctone, como insetos aquáticos e terrestres, algas e vegetais superiores, \\
detritos e sedimentos, entre outros \\
Dieta composta basicamente por insetos aquáticos \\
insetívoro \\
insetívoro-piscívoro \\
$\begin{array}{l}\text { Os itens mais freqüentes são peixes (e/ou escamas), insetos aquáticos e, } \\
\text { ocasionalmente, em algumas espécies, artrópodes terrestres }\end{array}$ \\
\hline
\end{tabular}

Após a identificação de todos os indivíduos, os lotes por espécie foram pesados em conjunto em uma balança marca Bell com capacidade de $600 \mathrm{~g}$ e resolução 0,001 g. O presente estudo foca a biomassa total das amostras e biomassa por espécie, em alguns casos. 


\subsection{Análises estatísticas}

Os dados obtidos através dos procedimentos descritos anteriormente, nas 60 microbacias selecionadas, foram analisados visando atender os objetivos listados na Introdução. Parte destas análises estatísticas foram realizadas em conjunto com o Prof. Dr. Edwin Moises Marco Ortega, do Departamento de Ciências Exatas da ESALQ/USP, especialmente as análises multivariadas, item 3.5.3.

Diversos métodos estatísticos usuais foram empregados, guiando-se basicamente pelo trabalho de Zar (1999), como por exemplo, cálculo de médias, modas, medianas, variâncias, e testes simples de comparação de médias para dados independentes (testes $t$ ) e dependentes (testes $t$-pareados). além da análise de variância (ANOVA tipo 1). Eventualmente foram empregados testes do tipo Qui-quadrado. Os testes foram comparados ao valor crítico de probabilidade de erro tipo I igual a $5 \%$.

\subsubsection{Objetivo 1}

Determinar padrões na estrutura das comunidades de peixes amostradas, seja em relação à composição específica, aos grupos tróficos e à biomassa.

As listas de espécies e suas respectivas abundâncias foram analisadas através de estatísticas descritivas. Foram criadas curvas de ordenação de espécies por abundância de indivíduos e biomassa, e curvas de ordenação por grupos tróficos por abundância de indivíduos e biomassa. As amostras foram reunidas pelos grupos de microbacias, somando-se as estações seca e chuvosa.

Análises de agrupamento hierárquico (cluster) foram realizadas a partir dos dados de abundância por espécie. Neste caso, duas análises em paralelo foram conduzidas, uma para cada conjunto de amostras tomadas nas estações chuvosa e seca. Os agrupamentos mais conspícuos foram destacados e descritos. Foi utilizada como medida de distância entre as amostras, a recíproca do índice de similaridade (portanto, dissimilaridade) de Morisita-Horn (Magurran 1988), e como método de ligação (agrupamento), o procedimento de Ward (Legendre \& Legendre 1998). 
A recíproca do índice de Morisita-Horn $\left(C_{M H r}\right)$ de um par de amostras qualquer, $a$ e $b$, com $i$ espécies e $a N$ e $b N$ indivíduos é obtida pela fórmula:

$C_{M H r}=1-\left[2 \times \sum\left(a n_{i} \times b n_{i}\right)\right] \times[(d a+d b) \times a N \times b N]^{-1}$,

onde: $d a=\sum a n_{i}^{2} \times a N^{-2}$ e $d b=\sum b n_{i}^{2} \times b N^{-2}$

A partir dos gráficos resultantes, foram definidos grupos de $40 \%$ de dissimilaridade. Trata-se de uma escolha arbitrária norteada, no entanto, pelos fatos: 1) todas as amostras são de riachos de tamanho relativamente homogêneo e os grupos devem representar padrões (i.e., "tipos") das comunidades de cabeceiras de riachos, isto é, poucas associações discretas devem ocorrer e; 2) a clareza do gráfico resultante, que mostrou maior coesão (menor proximidade entre grupos e amostras) a partir de medidas menores que $40 \%$ de dissimilaridade.

Os grupos foram caracterizados por: 1) exclusividade da espécie no grupo; 2) constância das espécies nos grupos (consideradas espécies ocorrendo em mais de 70 \% das amostras do grupo) e 3) dominância da espécie do grupo (considerada como a espécie com mais de $20 \%$ do total de indivíduos do grupo). Tais critérios foram definidos a posteriori, comparando-se as listas de abundância por espécies dos grupos obtidos nas estações seca e chuvosa.

\subsubsection{Objetivo 2}

Verificar se existe relação entre a riqueza e a diversidade de espécies de peixes e o uso e a cobertura do solo.

As microbacias foram categorizadas pela variável CD (cobertura dominante do solo, Tabela 13) sendo separadas em três grupos: microbacias de predomínio de canaviais, de matas nativas e de pastagens. As amostras nestas microbacias foram reunidas em duas: 60 amostras obtidas na estação chuvosa e 58 amostras obtidas na estação seca, isto é, a mesma questão foi abordada em duas situações, consideradas independentes. A hipótese nula a ser testada é a de que não há diferenças significativas no número de espécies entre as categorias listadas, ou: 


$$
H_{o}: K_{\text {nativas }}=K_{\text {canaviais }}=K_{\text {pastagen }}(1)
$$

Onde $K$ representa um descritor qualquer de composição específica e de abundância das espécies de peixes (como $S, N$ e $H^{\prime}$, por exemplo). De forma análoga, foi testada a hipótese envolvendo os grupos de amostras de microbacias de predomínio de pastagens e as "ripárias":

$$
H_{0}: K_{\text {pastagens }}=K_{\text {ripárias }}(2)
$$

Para verificar as hipóteses 1 e 2, foram realizados, respectivamente, testes ANOVA tipo I (efeitos randômicos) e testes $t$ para amostras independentes através do software Statistica 5.0. As variáveis-resposta foram testadas quanto à sua normalidade pelo teste de Shapiro-Wilk, a homogeneidade de variâncias de Brown-Forshyte, e os erros verificados contra a presença de tendências em relação aos valores observados em gráficos de dispersão de pontos. O poder dos testes foi testado post hoc, a partir de fórmulas padrão descritas em Sokal \& Rohlf (1995) e Zar (1999) para ANOVA (tipo I) e testes $t$. Os testes foram confrontados ao nível de $5 \%$ de significância, mas as análise foram, em geral, discutidas sob a forma de testes "relaxados" (Sokal \& Rohlf, 1995). Eventualmente, para fins de comparação, foram empregadas versões não-paramétricas destes testes (cf. Zar, op. cit.).

Foi realizada uma análise de correspondência simples através do software Minitab 11, utilizando-se dos valores de abundância $(N)$ e número de espécies totais amostrados por todas as microbacias com predomínio de canaviais, pastagens, matas nativas e ripárias. As curvas de ordenação de espécies por ordem de importância de abundância obtidas deste conjuntos de dados foram log-transformadas (base 10), e suas inclinações comparadas através do método proposto por Zar (1999, página 369). 


\subsubsection{Objetivo 3}

Correlacionar os descritores citados no objetivo 1 às condições físicas $e$ químicas dos riachos nos quais foram amostradas as comunidades.

Para atender a este objetivo foram realizadas análises multivariadas, visando à redução e seleção de variáveis descritivas, e à geração de eixos ou dimensões capazes de explicitar a estrutura interna do conjunto de amostras que pudessem ter algum significado ecológico. Neste ponto as microbacias não foram separadas em categorias, mas buscou-se avaliar a importância relativa de parâmetros mensurados na escala da microbacia, de entorno do canal e de habitat. Foi construída uma matriz de correlações de (todas as) variáveis e também gráficos bivariados. As variáveis descritivas (Tabelas 10, 11 e 15) puderam ser agrupadas em categorias, representando descrições em níveis diferenciados, e de detalhe progressivo, como segue:

1. Variáveis de hierarquia hidrológica: HS, SH, DL, DE, DQ e EL;

2. Métricas de microbacias: EM, DG, DD, CI e OR;

3. Uso e cobertura do solo na microbacia: CD, CP, DC, UC, UP, UE, UM, UF, UA, UI, UR, UV, UU, DB, AJ e AM;

4. Variáveis geológicas e pedológicas: ER e TS;

5. Variáveis de qualidade da água: AT, NN, NI, PT, KA, CA, MG, SE, AZ, DU, $\mathrm{CO}, \mathrm{CR}, \mathrm{TU}, \mathrm{CN}, \mathrm{pH}, \mathrm{OD}, \mathrm{SA}$ e TG;

6. Variáveis de métrica de segmento: SI, DR, BM, AB, LP, CV, AP, SO, IS e $\mathrm{TC}$;

7. Variáveis de métrica de canal: NU, PC, RP, QT, VE, PF, UB, VM, LM, PM, PX, VP, AC, VC, DS, MS, PA, OV, MV, VV e PU.

Logicamente, nem todas as variáveis foram analisadas, e a matriz de correlação criada com o conjunto de descritores (Anexo $\mathrm{H}$ ) verificou a existência de grande número de variáveis redundantes, que foram excluídas da análise, eventualmente.

Neste ponto, as análises foram conduzidas principalmente com os dois grandes conjuntos de amostras, 60 e 58 amostras.

Para cada conjunto de amostras, um modelo de regressão múltipla foi construído 
através do software SPSS, utilizando como variável-resposta o índice de diversidade de Shannon $\left(H^{\prime}\right)$. Para iniciar a modelagem, foram selecionadas, dentro de cada um dos grupos de variáveis descritivas, aquelas que apresentaram "boa" correlação ( $r$ de Pearson) com o índice de diversidade $H^{\prime}$, isto é, valores maiores ou iguais a $0,3 \mathrm{e}$ significativos ao nível de 0,05 . As variáveis selecionadas foram adicionadas e retiradas manualmente do modelo a fim de maximizar o valor de $R_{a j}^{2}$ (= coeficiente ajustado de determinação) e tendo em vista a capacidade do modelo em explicar a variável resposta, o que foi verificado através de uma análise de variância sobre o modelo. A dispersão dos resíduos do modelo foi verificada visualmente quanto a alguma tendência.

Nestes modelos não foram incluídas as variáveis nominais (v. Anexo C).

Em adição à esta modelagem, foi conduzida uma análise de ordenação dos dois conjuntos de amostras através do procedimento de escalonamento multidimensional nãométrico (Legendre \& Legendre, 1998), denominado aqui como NMDS. Este procedimento não depende da distribuição paramétrica das variáveis a serem ordenadas, no caso, a similaridade (Morisita-Horn) entre os pares de amostras dos conjuntos das estações chuvosas e secas. O NMDS pode admitir soluções variadas, isto é, a análise pode ser conduzida para produzir entre uma a nove dimensões (eixos), sendo que a discrepância (stress) entre a ordenação obtida e a ordenação original (real) dos dados tende a ser menor tanto quanto maior for o número de dimensões utilizadas na análise. A escolha do número de dimensões e o nível de stress deve ser um compromisso entre a validade estatística do método e a didática, pois se torna oneroso avaliar muitas dimensões de uma ordenação (Kruskal \& Wish, 1978).

Nos gráficos de ordenação resultantes foram delineados (com formas geométricas simples) os agrupamentos obtidos nas análises descritas no item 3.5.1. Os pontos (amostras) discrepantes foram indicados aos grupos a que pertencem através de setas. Em seguir, foram analisadas as correlações entre as dimensões e diversas variáveis descritivas do meio ambiente. As correlações significativas e relevantes foram representadas nos gráficos de ordenação. 


\subsubsection{Objetivo 4}

Entender como se distribui a diversidade de peixes de riachos no contexto da Bacia do Rio Corumbataí.

Parte deste objetivo é diretamente atendido pelas análises do item anterior, uma vez que foram testadas variáveis representativas de hierarquia hidrológica, como ordenação de rios (Strahler, Shreve) e ligação-à-jusante (D-link).

Para cada uma das sub-bacias consideradas na Tabela 3, foram calculados os índices de diversidade de Whittaker $\left(B_{W}\right)$ segundo Magurran (1988), conforme a fórmula abaixo:

$$
B_{W}=S \times\left(S_{\text {médio }}-1\right)^{-1},
$$

onde $S$ é o número total de espécies observados na sub-bacia, e $S_{\text {médio }}$ é a média do número de espécies encontradas nos riachos das sub-bacias. Neste ponto, foi utilizado os pares de amostras de cada microbacia, a fim de se determinar o número de espécies acumulados para cada uma delas. Algumas correlações entre os $B_{W}$ obtidos para cada sub-bacia e variáveis ambientais foram realizadas.

Foram construídos mapas temáticos ilustrando os estados das variáveis $H^{\prime}, N$ e $B T$ em cada uma das microbacias. O objetivo destes mapas é o de visualizar padrões de diversidade e abundância de peixes em áreas discretas, dentro da Bacia do Rio Corumbataí.

\subsubsection{Abrangência e eficácia do levantamento}

Finalmente, a fim de se determinar a abrangência e a eficácia deste levantamento de espécies de riachos da bacia, foram analisadas as curvas do coletor através do programa EstimateS 7.0 (Colwell, 2004). Foram conduzidas análises para o conjunto de amostras obtidas nas estações seca e chuvosa. Através deste software, foram obtidos os estimadores de riqueza de espécies de Jacknife e Bootstrap. Estes foram comparados ao total de espécies observadas para os conjuntos de amostras das estações chuvosas e secas. 
A partir da série de dados aleatorizados da acumulação de espécies em função do número de amostras (obtidas do EstimateS 7.00), ajustou-se uma função do tipo: $y=a(b$ $-e^{-\mathrm{cx}}$ ) através do software Curve Expert 1.3 (Hyams, 2001), a fim de se obter o valor assintótico da função quando $\mathrm{x}$ (número de amostras) igualava $10^{30}$. Este valor, denominado $S a$, também foi utilizado como um estimador da riqueza total de espécies do conjunto de amostras. 


\section{RESULTADOS}

\subsection{Composição das amostras}

\subsubsection{Composição específica}

As 118 amostras tomadas neste estudo continham um total de 51 espécies e um total de 53.806 indivíduos. Foram identificadas espécies de seis ordens, 14 famílias e 37 gêneros. As espécies foram listadas abaixo por sua posição sistemática, constando nomes científico e vulgar. As espécies assinaladas com * necessitam de detalhamento em sua determinação. As espécies marcadas com \# são exóticas, introduzidas ou invasoras.

\section{Ordem: Characiformes}

Família: Parodontidae

Apareiodon affinis (Steindachner, 1879) * - canivete

Apareiodon ibitiensis Campos, 1944 - canivete

Parodon nasus Kner, 1859 - canivete

Família: Curimatidae

Subfamília: Curimatinae

Cyphocharax modestus - (Fernández-Yépez, 1948) saguirú

Cyphocharax vanderi (Britski, 1980) - saguirú

Steindachnerina insculpta (Fernández-Yépez, 1948) - saguirú

Família: Crenuchidae

Subfamília: Characidiinae

Characidium gomesi Travassos, 1956 - canivete 
Characidium cf. zebra Eigenmann, 1909 - canivete

Família: Characidae

Subfamília: Incertae Sedis ("Tetragonopterinae")

Astyanax altiparanae Garutti \& Britski, 2000 - tambiú

Astyanax paranae Eigenmann, 1914 - lambari

Astyanax aff. eigenmanniorum (Cope, 1894) - lambari

Astyanax cf. fasciatus (Cuvier, 1819) - lambari-do-rabo-vermelho

Astyanax sp. $1 *$ - lambari

Astyanax sp. $2 *$ - lambari

Astyanax sp. $3 *$ - lambari

Bryconamericus sp. $1 *$ - lambari

Bryconamericus sp. $2 *$ - lambari

Hyphessobrycon eques (Steindachner, 1882) - lambari

Oligosarcus sp. (Campos, 1945) * - lambari-cachorro

Piabina argentea Reinhardt, 1867 - lambari

Subfamília: Cheirodontinae

Serrapinnus heterodon Eigenmann, 1915 - lambari

Serrapinnus notomelas Eigenmann, 1915 - lambari

Serrapinnus sp. * - lambari

Subfamília: Glandulocaudinae

Planaltina sp. * - lambari

Família: Erythrinidae

Hoplias malabaricus (Bloch, 1794) - traíra

\section{Ordem: Siluriformes}

Família: Trichomycteridae

Subfamília: Trichomycterinae

Trichomycterus sp. - bagrinho

Família: Callichthyidae

Subfamília: Corydoradinae

Corydoras cf. aeneus (Gill, 1858) - ronquinho, sarro 
Corydoras flaveolus Ihering, 1911 - ronquinho, sarro

Subfamília: Callichthyinae

Callichthys callichthys (Linnaeus, 1758) - tamboatá

Hoplosternum littorale (Hancock, 1828) - caborja

Família: Loricariidae

Subfamília: Neoplecostominae

Neoplecostomus paranensis Langeani, 1990 - cascudo

Subfamília: Hypoptopomatinae

Corumbataia cuestae Britski, 1997 - cascudinho

Hisonotus sp. * - cascudinho

Subfamília: Loricariidae

Rineloricaria latirostris (Boulenger, 1900) - cascudo-lagartixa

Subfamília: Hypostominae

Hypostomus ancistroides (Ihering, 1911) - cascudo

Hypostomus cf. strigaticeps (Regan, 1908) - cascudo

Loricariidae não identificado - cascudo

Família: Heptapteridae

Rhamdia cf. quelen (Quoy \& Gaimard, 1824) - bagre

Cetopsorhamdia iheringi Schubart \& Gomes, 1959 - bagrinho

Pimelodella sp. * - mandi

Imparfinis schubarti (Gomes, 1956) - bagrinho

Heptapteridae gen. n. sp. n. * - bagrinho

\section{Ordem: Gymnotiformes}

Família: Gymnotidae

Gymnotus spp. - tuvira, sarapó

Família: Sternopygidae

Eigenmannia sp. - tuvira amarela

\section{Ordem: Cyprinodontiformes}

Família: Poeciliidae

Subfamília: Poeciliinae 
Poecilia reticulata Peters, 1859 \# - guarú

Phalloceros caudimaculatus (Hensel, 1868) - guarú

\section{Ordem: Perciformes}

Família: Cichlidae

Subfamília: Geophaginae

Geophagus brasiliensis (Quoy \& Gaimard, 1824) - cará

Subfamília: Cichlasomatinae

Cichlasoma aff. facetum (Jenyns, 1842) - cará preto

Subfamília: Pseudocrenilabrinae

Oreochromis niloticus niloticus (Linnaeus, 1758) \# - tilápia-do-nilo

Tilapia rendalli (Boulenger, 1897) \# - tilápia

\section{Ordem: Synbranchiformes}

Família: Synbranchidae

Synbranchus aff. marmoratus Bloch, 1795 - mussum

As espécies de lambari Astyanax sp. 1, Astyanax sp. 2 e Astyanax sp. 3, não identificadas, não puderam ser determinadas com base na chave de identificação de Garutti \& Britski (2000). Assemelham-se a espécies dos complexos fasciatus (sp. 1 e sp. 3) e ao complexo eigenmanniorum (sp. 2). O uso do epíteto Astyanax paranae, ao invés de Astyanax scabripinnis paranae, segue o esquema proposto em Reis et al. (2003), onde não são reconhecidas sub-espécies, que foram elevadas ao nível de espécies. Bryconamericus sp. 1 assemelha-se a Bryconamericus sp. ilustrado em Castro et al. (2003, figura 6, página 15, foto 8). Bryconamericus sp. 2 pode se tratar de uma espécie nova (F. C. T. Lima, comunicação pessoal). Os nomes de famílias e subfamílias seguiram aqueles usados em Reis et al. (2003) e Froese \& Pauly (2004). Em Gymnotus spp. há as espécies Gymnotus cf. carapo e G. sylvius (Dr. William Crampton e Flávio C. T. Lima, comunicação pessoal), não separadas nas análises deste estudo. Alguns dos indivíduos das espécies de tilápia podem se tratar de híbridos, e foram identificadas de maneira tentativa, uma vez que se tratavam de exemplares jovens, menores que $100 \mathrm{~mm}$ 
de comprimento-padrão. O material será depositado, em parte, na coleção do Museu de Zoologia da Universidade de São Paulo (MZUSP).

Nota-se grande diversificação ao nível das famílias, especialmente Characidae, Loricariidae, Heptapteridae e Callichthyidae. A Figura 15 ilustra a distribuição do número de espécies nas 14 famílias amostradas durante este trabalho. Observa-se que $82,4 \%$ das espécies pertencem às ordens Characiformes e Siluriformes, sendo 49,0\% das espécies pertencentes à primeira delas.

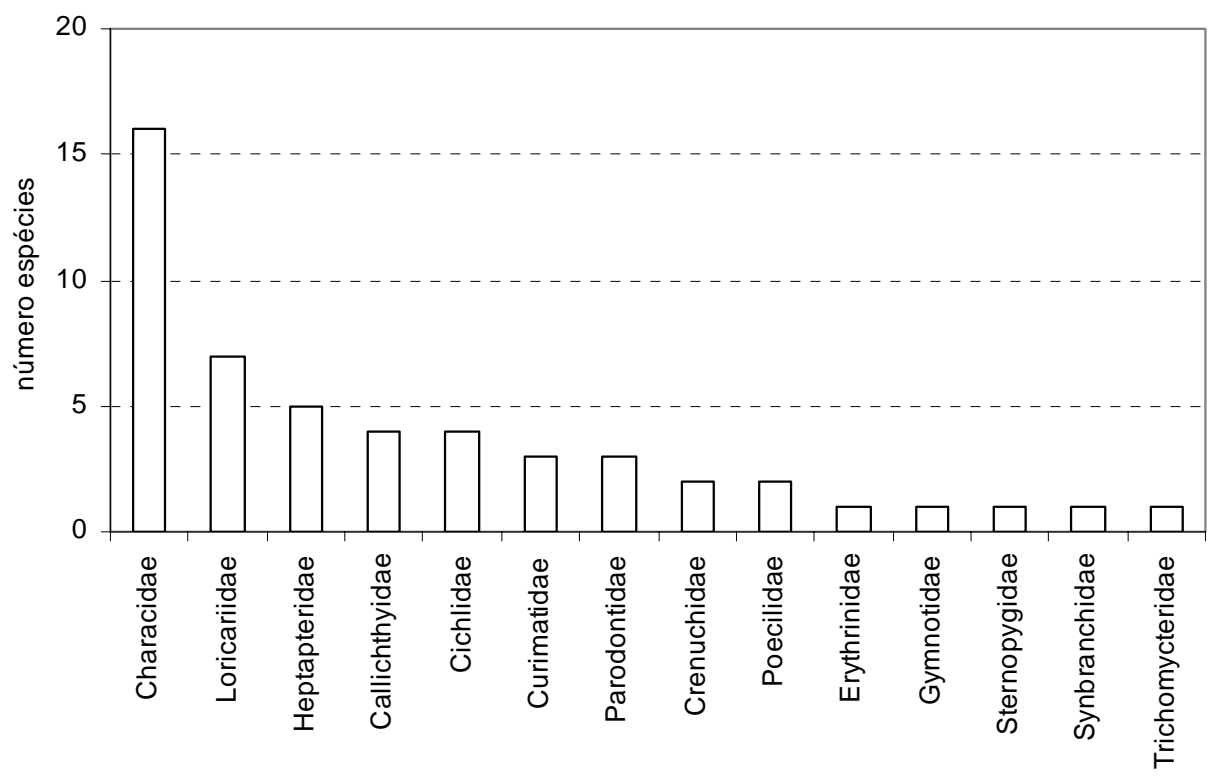

Figura 15 - Número de espécies pertencentes a cada uma das 14 famílias amostradas em 60 riachos da Bacia do Rio Corumbataí

Além das espécies citadas acima, foi necessário delimitar categorias não taxonômicas para indivíduos não identificados, que foram nomeadas como: Astyanax juvenis não identificados (considerada uma espécie por lote), larvas de Loricariidae não identificadas (idem) e larvas de peixes não identificadas (mais de uma espécie por lote).

$\mathrm{Na}$ Tabela 18 são apresentados códigos de duas letras para cada espécie ou categoria dos indivíduos amostrados, a serem utilizados em tabelas e figuras ao longo do texto. 
Tabela 18. Códigos de espécies e categorias taxonômicas utilizadas ao longo deste trabalho

\begin{tabular}{|c|c|c|c|}
\hline Espécie ou categoria & Código & Espécie ou categoria & Código \\
\hline Parodon nasus & PN & Corydoras cf. aeneus & $\mathrm{CA}$ \\
\hline Apareiodon affinis & AS & Corydoras flaveolus & $\mathrm{CF}$ \\
\hline Apareiodon ibitiensis & AI & Callichthys callichthys & $\mathrm{CC}$ \\
\hline Cyphocharax modestus & $\mathrm{CS}$ & Hoplosternum littorale & $\mathrm{HL}$ \\
\hline Cyphocharax vanderi & $\mathrm{CV}$ & Neoplecostomus paranensis & $\mathrm{NP}$ \\
\hline Steindachnerina insculpta & SI & Corumbataia cuestae & $\mathrm{CO}$ \\
\hline Characidium cf. zebra & $\mathrm{CZ}$ & Hisonotus sp. & MP \\
\hline Characidium gomesi & $\mathrm{CG}$ & Rineloricaria latirostris & RL \\
\hline Astyanax altiparanae & AA & Hypostomus ancistroides & HA \\
\hline Astyanax paranae & $\mathrm{AP}$ & Hypostomus cf. strigaticeps & $\mathrm{HP}$ \\
\hline Astyanax aff. eigenmanniorum & $\mathrm{AE}$ & Loricariidae não identificado & $\mathrm{LN}$ \\
\hline Astyanax fasciatus & $\mathrm{AF}$ & Loricariidae juvenis não identificados & LJ \\
\hline Astyanax sp. 1 & $\mathrm{AT}$ & Rhamdia cf. quelen & RQ \\
\hline Astyanax sp. 2 & AR & Cetopsorhamdia iheringi & $\mathrm{CI}$ \\
\hline Astyanax sp. 3 & $\mathrm{AZ}$ & Pimelodella sp. & PS \\
\hline Astyanax juvenis não identificados & $\mathrm{AJ}$ & Imparfinis schubarti & IS \\
\hline Bryconamericus sp. 1 & $\mathrm{BC}$ & Heptapteridae gen. n. sp. n. & DS \\
\hline Bryconamericus sp. 2 & $\mathrm{BF}$ & Eigenmannia sp. & ES \\
\hline Hyphessobrycon eques & $\mathrm{HE}$ & Gymnotus cf. carapo & GC \\
\hline Piabina argentea & $\mathrm{PA}$ & Poecilia reticulata & $\mathrm{PR}$ \\
\hline Oligosarcus sp. & OS & Phalloceros caudimaculatus & $\mathrm{PC}$ \\
\hline Serrapinnus heterodon & $\mathrm{SH}$ & Geophagus brasiliensis & GB \\
\hline Serrapinnus notomelas & $\mathrm{SN}$ & Cichlasoma aff. facetum & $\mathrm{CP}$ \\
\hline Serrapinnus sp. & SS & Oreochromis niloticus niloticus & ON \\
\hline Planaltina sp. & PL & Tilapia rendalli & $\mathrm{TR}$ \\
\hline Hoplias malabaricus & HM & Synbranchus aff. marmoratus & SM \\
\hline Trichomycterus sp. & TS & Larvas de peixes não identificadas & LI \\
\hline
\end{tabular}




\subsubsection{Composição em grupos tróficos}

As espécies e categorias listadas na Tabela 18 foram alocadas em seis níveis tróficos distintos, classificação apresentada na Tabela 19.

A Figura 16 ilustra a distribuição do número de espécies em cada uma das categorias tróficas, considerando seis grupos de hábitos alimentares. Considerando-se os grupos tróficos bentófago e onívoro como os menos especializados entre os aqui considerados, tem-se que 49,1 \% das espécies estão relacionadas a este grupo. De maneira geral, os bentófagos apresentam hábitos bento-pelágicos, enquanto os onívoros tendem a ocupar o compartimento pelágico (coluna d'água). A Figura 16 indica, também, que dois dos grupos são mais freqüentes: detritívoro-algívoro e onívoro. Os detritívoro-iliófagos, com modificações características no trato digestivo, e os insetívoro-piscívoros, de hábitos macrófagos, predadores de topo de cadeia, considerando os peixes, estão entre as espécies menos freqüentes. 
Tabela 19. Grupos tróficos de 53 espécies e categorias de peixes de riachos da Bacia do Rio Corumbataí

\begin{tabular}{|c|c|c|c|}
\hline Espécie ou categoria & $\begin{array}{l}\text { Grupo } \\
\text { trófico }\end{array}$ & Espécie ou categoria & $\begin{array}{l}\text { Grupo } \\
\text { trófico }\end{array}$ \\
\hline Parodon nasus & da & Corydoras cf. aeneus & be \\
\hline Apareiodon affinis & da & Corydoras flaveolus & be \\
\hline Apareiodon ibitiensis & da & Callichthys callichthys & be \\
\hline Cyphocharax vanderi & di & Hoplosternum littorale & be \\
\hline Cyphocharax sp. & di & Neoplecostomus paranensis & da \\
\hline Steindachnerina insculpta & $\mathrm{di}$ & Corumbataia cuestae & da \\
\hline Characidium cf. zebra & in & Hisonotus sp. & da \\
\hline Characidium gomesi & in & Rineloricaria latirostris & da \\
\hline Astyanax altiparanae & on & Hypostomus ancistroides & da \\
\hline Astyanax paranae & on & Hypostomus cf. strigaticeps & da \\
\hline Astyanax aff. eigenmanniorum & on & Loricariidae não identificado & da \\
\hline Astyanax fasciatus & on & Loricariidae juvenis não identificados & da \\
\hline Astyanax sp. 1 & on & Rhamdia cf. quelen & on \\
\hline Astyanax sp. 2 & on & Cetopsorhamdia iheringi & in \\
\hline Astyanax sp. 3 & on & Pimelodella sp. ${ }^{2}$ & in \\
\hline Astyanax juvenis não identificados & on & Imparfinis schubarti & in \\
\hline Bryconamericus sp. 1 & on & Heptapteridae gen. n. sp. n. & in \\
\hline Bryconamericus sp. 2 & on & Eigenmannia sp. & be \\
\hline Hyphessobrycon eques & in & Gymnotus cf. carapo & be \\
\hline Piabina argentea & in & Poecilia reticulata & on \\
\hline Oligosarcus sp. & ip & Phalloceros caudimaculatus & on \\
\hline Serrapinnus heterodon & on & Geophagus brasiliensis & on \\
\hline Serrapinnus notomelas & on & Cichlasoma aff. facetum & in \\
\hline Serrapinnus sp. & on & Oreochromis niloticus niloticus & be \\
\hline Planaltina sp. ${ }^{1}$ & in & Tilapia rendalli & be \\
\hline Hoplias malabaricus & ip & Synbranchus aff. marmoratus & be \\
\hline Trichomycterus sp. & in & - & - \\
\hline
\end{tabular}

Referências: ${ }^{1}$ Dufech et al. (2001), ${ }^{2}$ Castro \& Casatti (1997). Legenda para os grupos tróficos: da = detritívoro-algívoro, di = detritívoro-iliófago, in = insetívoro, on = onívoro, ip = insetívoropiscívoro e be $=$ bentófago. Baseado em Sawakuchi et al. (em preparação), exceto quando indicado por números junto aos códigos dos grupos tróficos. 


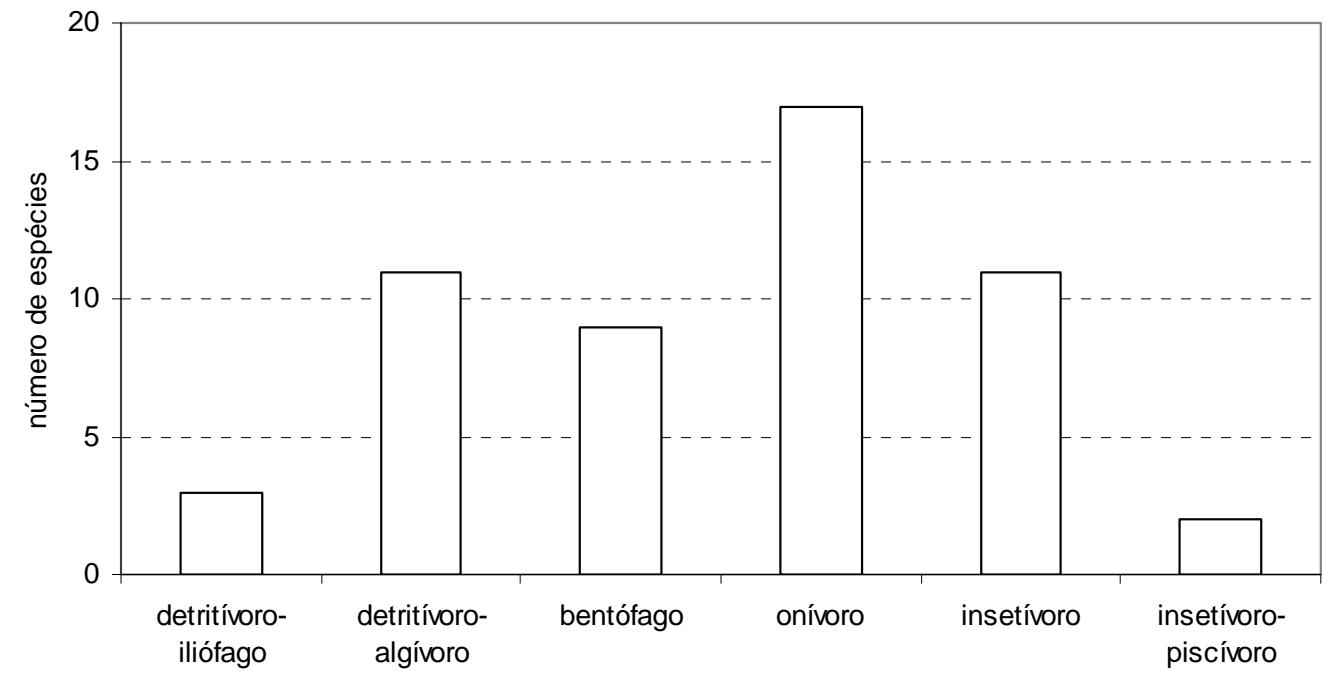

Figura 16 - Distribuição de 53 espécies e categorias de peixes em seis grupos tróficos, coletados em riachos da Bacia do Rio Corumbataí, SP

\subsubsection{Freqüência de ocorrência e abundância do número de indivíduos, biomassa e grupos tróficos - total de amostras}

A Tabela 20 mostra a distribuição do total de indivíduos e da biomassa em cada uma das famílias e ordens, e grupos tróficos definidos no item anterior, considerando as 118 amostras obtidas durante este estudo. A Tabela 20 indica que ficam mantidos os padrões gerais de freqüência de indivíduos e de biomassa pelos grupos considerados, ao que se observou na distribuição por número de espécies nestas mesmas categorias. Dentre as famílias, destaca-se Heptapteridae, tanto em termos de indivíduos quanto em biomassa total. As ordens Cyprinodontiformes e Perciformes claramente invertem sua importância entre indivíduos e biomassa devido ao tamanho corporal médio dos indivíduos de ambas, pequeno na primeira, e de médio a grande na segunda. Há uma porcentagem considerável de onívoros e insetívoros, somando $82,9 \%$ dos indivíduos e $72,9 \%$ da biomassa total.

Em seguida, as espécies e categorias amostradas foram ranqueadas de acordo com sua freqüência de ocorrência, número total de indivíduos e biomassa, gerando as 
Figuras 17 a 19. A Tabela 21 mostra as 10 espécies mais importante em termos de ocorrência, número de indivíduos e biomassa total.

Tabela 20. Número de indivíduos totais $\left(n_{i}\right)$, porcentagem do total $(n \%)$, biomassa de indivíduos totais $\left(m_{i}\right)$ e porcentagem do total $(m \%)$ de 53 espécies e categorias de peixes coletados em 118 amostras de riachos da Bacia do Rio Corumbataí*

\begin{tabular}{lrrrr}
\hline \multirow{2}{*}{ Categorias } & Número de indivíduos & \multicolumn{2}{c}{ Biomassa total $(\mathrm{g})$} \\
& $n i$ & $n \%$ & $m i$ & $m \%$ \\
\hline Parodontidae & 157 & 0,3 & $1.001,50$ & 1,0 \\
Curimatidae & 326 & 0,6 & $2.949,30$ & 2,9 \\
Crenuchidae & 1.861 & 3,5 & $3.530,20$ & 3,5 \\
Characidae & 17.494 & 32,5 & $34.208,57$ & 33,5 \\
Erythrinidae & 183 & 0,3 & $6.258,22$ & 6,1 \\
Trichomycteridae & 7.214 & 13,4 & $8.612,73$ & 8,4 \\
Callichthyidae & 653 & 1,2 & $1.990,43$ & 2,0 \\
Loricariidae & 7.058 & 13,1 & $9.721,19$ & 9,5 \\
Heptapteridae & 10.422 & 19,4 & $19.559,04$ & 19,2 \\
Gymnotidae & 449 & 0,8 & $4.313,03$ & 4,2 \\
Sternopygidae & 180 & 0,3 & 427,28 & 0,4 \\
Poeciliidae & 6.168 & 11,5 & $1.164,70$ & 1,1 \\
Cichlidae & 1.547 & 2,9 & $7.610,42$ & 7,5 \\
Synbranchidae & 67 & 0,1 & 669,23 & 0,7 \\
Total & 53.779 & 100,0 & $102.015,83$ & 100,0 \\
Characiformes & 20.021 & 37,23 & $47.947,78$ & 47,0 \\
Siluriformes & 25.347 & 47,13 & $39.883,39$ & 39,1 \\
Gymnotiformes & 629 & 1,17 & $4.740,31$ & 4,6 \\
Cyprinodontiformes & 6.168 & 11,47 & $1.164,70$ & 1,1 \\
Perciformes & 1.547 & 2,88 & $7.610,42$ & 7,5 \\
Synbranchiformes & 67 & 0,12 & 669,23 & 0,7 \\
Total & 53.779 & 100,0 & $102.015,83$ & 100,0
\end{tabular}


Tabela 20. Número de indivíduos totais $\left(n_{i}\right)$, porcentagem do total $(n \%)$, biomassa de indivíduos totais $\left(m_{i}\right)$ e porcentagem do total $(\mathrm{m} \%)$ de 53 espécies e categorias de peixes coletados em 118 amostras de riachos da Bacia do Rio Corumbataí

\begin{tabular}{|c|c|c|c|c|c|}
\hline & \multirow{2}{*}{ Categorias } & \multicolumn{2}{|c|}{ Número de indivíduos } & \multicolumn{2}{|c|}{ Biomassa total $(\mathrm{g})$} \\
\hline & & $n i$ & $n \%$ & $m i$ & $m \%$ \\
\hline \multirow{7}{*}{$\begin{array}{l}0 \\
0 \\
0 \\
0 \\
0 \\
0 \\
0 \\
0 \\
0 \\
0 \\
0\end{array}$} & Detritívoro-iliófago & 326 & 0,6 & $2.949,30$ & 2,9 \\
\hline & Detritívoro-algívoro & 7.215 & 13,4 & $10.722,69$ & 10,5 \\
\hline & Bentófago & 1.366 & 2,5 & $7.563,88$ & 7,4 \\
\hline & Onívoro & 25.496 & 47,4 & $50.615,32$ & 49,6 \\
\hline & Insetívoro & 19.099 & 35,5 & $23.720,15$ & 23,3 \\
\hline & Insetívoro-piscívoro & 277 & 0,5 & $6.444,49$ & 6,3 \\
\hline & Total & 53.779 & 100,0 & $102.015,83$ & 100,0 \\
\hline
\end{tabular}

*As larvas não identificadas foram excluídas da análise. São 27 indivíduos com massa de 0,41 gramas 


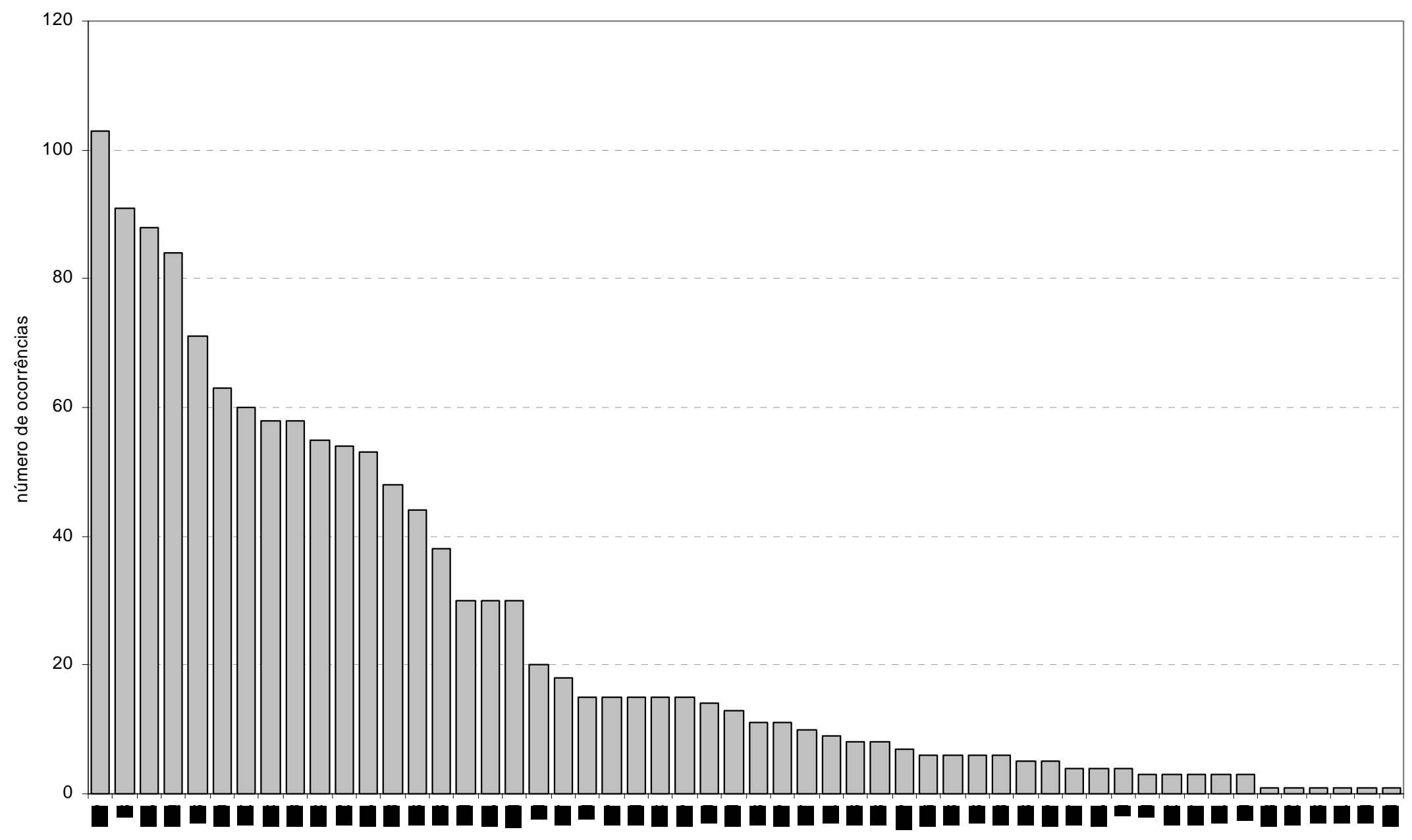

Figura 17 - Número de ocorrências de 54 espécies e categorias não taxonômicas (cf. Tabela 20) de peixes coletadas em 118 amostras de riachos da Bacia do Rio Corumbataí, SP 


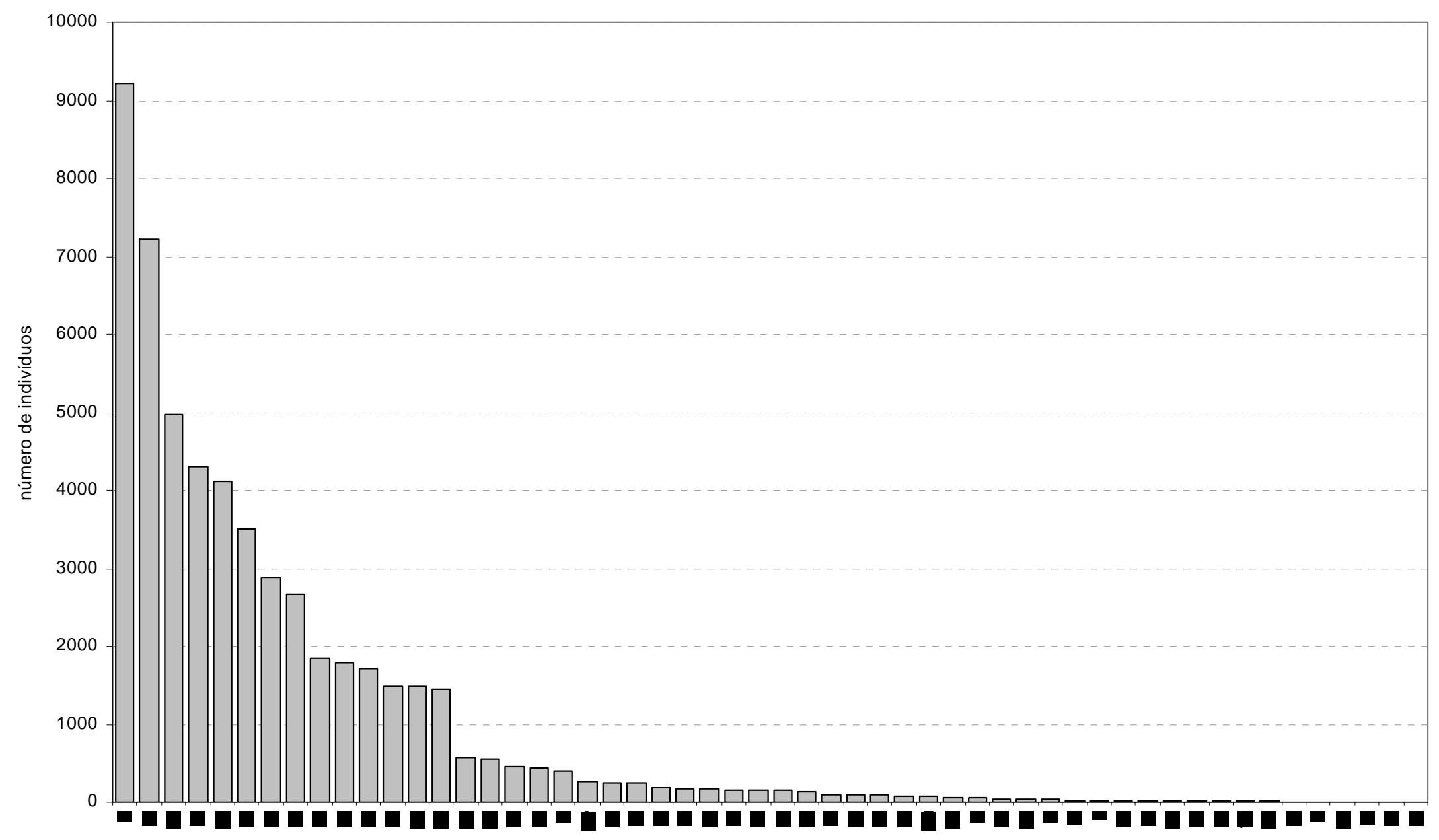

Figura 18 - Ordenação do número de indivíduos de 54 espécies e categorias não taxonômicas (cf. Tabela 20) de peixes coletadas em 118 amostras de riachos da Bacia do Rio Corumbataí, SP 


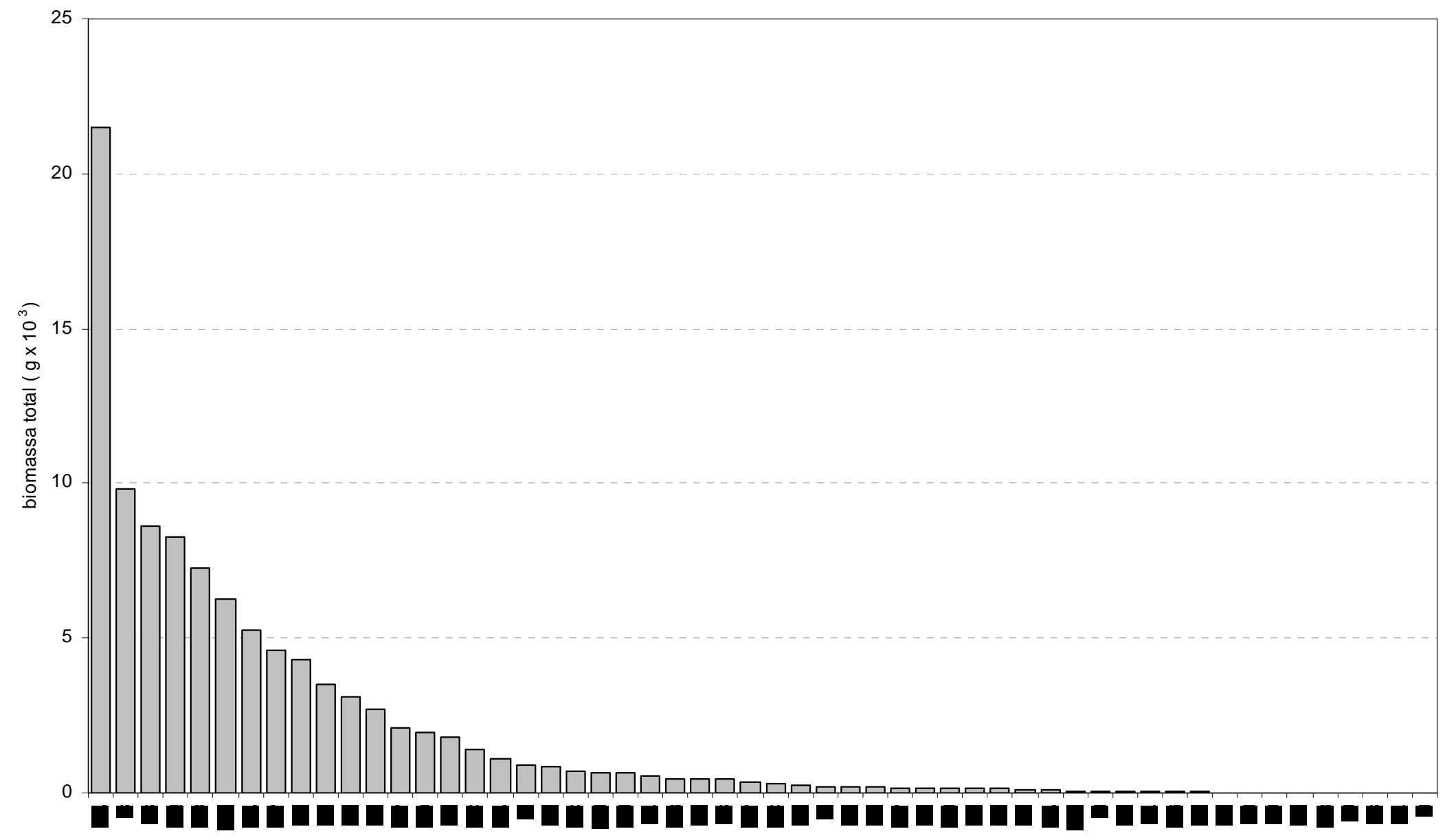

Figura 19 - Ordenação de 54 espécies e categorias não taxonômicas (cf. Tabela 20) de peixes por biomassa total coletada em 118 amostras de riachos da Bacia do Rio Corumbataí, SP 
Tabela 21. Ranqueamento em ordem decrescente das dez espécies mais importantes em termos de número de ocorrências, número de indivíduos e biomassa total em um total de 118 amostras de riachos da Bacia do Rio Corumbataí, SP

\begin{tabular}{|c|c|c|c|}
\hline Posição & Número de ocorrências & Número de indivíduos & Biomassa total \\
\hline $1^{o}$ & Astyanax paranae & Imparfinis schubarti & Astyanax altiparanae \\
\hline $2^{0}$ & Imparfinis schubarti & Trichomycterus sp. & Imparfinis schubarti \\
\hline $3^{\mathrm{o}}$ & Hypostomus ancistroides & Corumbataia cuestae & Trichomycterus sp. \\
\hline $4^{-0}$ & Rhamdia cf. quelen & Serrapinnnus heterodon & Rhamdia cf. quelen \\
\hline $5^{0}$ & Trichomycterus sp. & Astyanax altiparanae & Geophagus brasiliensis \\
\hline $6^{-}$ & Corumbataia cuestae & $\begin{array}{l}\text { Phalloceros } \\
\text { caudimaculatus }\end{array}$ & Hoplias malabaricus \\
\hline $7^{0}$ & Astyanax eigenmanniorum & Astyanax paranae & Hypostomus ancistroides \\
\hline $8^{\circ}$ & Bryconamericus sp. 1 & Poecilia reticulata & Astyanax paranae \\
\hline $9^{0}$ & Geophagus brasiliensis & Characidium cf. zebra & Gymnotus cf. carapo \\
\hline $10^{\mathrm{o}}$ & $\begin{array}{l}\text { Phalloceros } \\
\text { caudimaculatus }\end{array}$ & Astyanax fasciatus & Characidium cf. zebra \\
\hline $\begin{array}{l}\text { Porcentagem } \\
\text { representada }\end{array}$ & 55,0 & 79,0 & 77,8 \\
\hline
\end{tabular}

Pela Tabela 21 observa-se que três espécies podem ser consideradas como comuns (isto é, bem distribuídas, ubíquas), abundantes e importantes em biomassa. Elas são: Astyanax paranae, Imparfinis schubarti e Trichomycterus sp., respectivamente. No item 4.2.2 é demonstrado que diversas comunidades de peixes dos riachos são representadas unicamente por estas três espécies. Provavelmente representam aquelas mais capazes de colonizar os ambientes de cabeceira. Um segundo grupo pode ser delineado: espécies comuns e abundantes, como Corumbataia cuestae e Phalloceros caudimaculatus. São espécies de menor porte e, logicamente, menor importância em 
biomassa. Também são espécies comuns encontradas nos trechos relativamente mais altos dentre os riachos amostrados. Hypostomus ancistroides, Rhamdia cf. quelen e Geophagus brasiliensis são espécies de ocorrência comum e de grande importância em biomassa, mas baixa densidade, exceto em casos localizados. O último grupo, composto por Astyanax altiparanae e Characidium cf. zebra apresenta biomassa elevada e também alta densidade. Sua ocorrência está, entretanto, mais restrita a determinados tipos de canais, ou situações, no caso de Astyanax altiparanae, que parece subir sazonalmente trechos de riachos, migração de provável caráter reprodutivo.

\subsection{Padrões na estrutura das comunidades}

\subsubsection{Número de espécies, indivíduos, grupos tróficos, biomassa e diversidade por amostra}

As médias, amplitudes e desvios-padrão do número de espécies, famílias, indivíduos, grupos tróficos, biomassa total e os índices de diversidade de Shannon, eqüitatividade e recíproca do índice de Simpson por amostra foram dispostos na Tabela 22.

Estes descritores das comunidades de peixe apresentaram elevada variabilidade, a qual será analisada em maior detalhe no item 4.3. Parte desta heterogeneidade pode ser atribuída à grande variação no estado de conservação dos sítios amostrados, isto é, refletindo heterogeneidade ambiental. No entanto, as Figuras 20 a 22, mostrando a distribuição de freqüência de cada uma destas variáveis, informam sobre o comportamento geral destes descritores. Há uma clara distribuição bimodal no número de espécies, sendo uma moda ao redor de 6-8 espécies e outra entre 12-14 espécies. Já o número de famílias apresenta distribuição próxima à normal, ligeiramente assimétrica pela esquerda, apresentando a classe de 6-8 famílias por amostra como mais freqüente. O mesmo ocorre com o número de grupos tróficos: poucos trechos amostrados (10) possuíam comunidades compostas por 1 ou 2 grupos tróficos, sendo 3 o valor mais comum, embora comunidades mais complexas, com 4-6 grupos sejam abundantes. 
Tabela 22. Média, desvio-padrão, valores mínimos e máximos de descritores de diversidade e abundância de 118 amostras de peixes de riachos da Bacia do Rio Corumbataí, SP

\begin{tabular}{ccc}
\hline Variável & Média \pm Desvio-padrão & Mínimo - Máximo \\
\hline$S$ & $11,26 \pm 5,51$ & $1-26$ \\
$F$ & $6,81 \pm 2,44$ & $1-3$ \\
$N$ & $455,98 \pm 541,55$ & $1-5.114$ \\
$G T$ & $3,90 \pm 1,21$ & $1-6$ \\
$B T$ & $864,54 \pm 965,63$ & $0,19-5.534,08$ \\
$H^{\prime}$ & $1,57 \pm 0,54$ & $0,00-2,72$ \\
$E_{H}$ & $3,85 \pm 1,95$ & $0,00-8,75$ \\
$D_{r}$ & $0,69 \pm 0,17$ & $0,00-0,92$ \\
\hline
\end{tabular}

$S=$ número de espécies, $F=$ número de famílias, $N=$ número de indivíduos, $G T=$ número de grupos tróficos, $B T=$ biomassa total em gramas, $H^{\prime}$ = índice de diversidade de Shannon, $E_{H}$ = índice de eqüitatividade de Shannon e $D_{r}=$ recíproca do índice de Simpson

Tal como a ordenação por importância em número de indivíduos das espécies obtidas no conjunto de 118 amostras (Figura 18) assemelha-se à ordenação da importância das espécies por biomassa (Figura 19), a distribuição do número de indivíduos por amostra apresenta padrão semelhante à distribuição de biomassa total de peixes por amostra (Figura 21). Parece haver um limite no número de indivíduos (e biomassa) para o tamanho de canais amostrados neste estudo, muito embora estas variáveis $(N$ e $B T)$ não sejam, em geral, correlacionadas ao tamanho do canal em área, volume e, tampouco, à área da microbacia (v. item 4.3).

O gráfico B da Figura 21 mostra uma distribuição praticamente uniforme, com ligeira diminuição nas classes contendo mais de 600 indivíduos, sendo as amostras contendo mais de 1.000 indivíduos apenas oito. Em relação à biomassa total, padrão semelhante é observado: as amostras contendo mais de 3.000 gramas são todas de canais pouco ou nada sombreados, à exceção de duas amostras obtidas na estação chuvosa, 
onde foram coletados cardumes com muitos indivíduos de Astyanax altiparanae. Notese que a área das microbacias, área amostrada do canal e volume amostrado do canal não apresentam distribuição normal, sendo, também, fortemente assimétricas pela esquerda (v. Anexo E).

Quanto aos índices de Shannon, eqüitatividade de Shannon e recíproca de Simpson (Figura 22), observam-se três distribuições bimodais, mais ou menos claras. Estas distribuições estão provavelmente representando a distribuição bimodal da freqüência do número de espécies. Ocorre correlação considerável entre os índices (Anexo F) que, no entanto, representam atributos distintos da comunidade. Em relação às variáveis $H^{\prime}$ e $D_{r}$, vemos ligeira tendência aos valores mais elevados de diversidade, à direita da classe modal de maior diversidade, notadamente para a recíproca do índice de Simpson.

As distribuições dos índices de diversidade, espécies e grupos tróficos apresentam-se semelhantes entre si, assim como a biomassa e o número de indivíduos. É possível que estes dois "blocos" de descritores das comunidades sejam efetivamente influenciados por atributos ambientais distintos: tamanho de habitat para abundância e biomassa, e complexidade de habitat para diversidade, riqueza e eqüitatividade (v. item 4.3.2).

Uma vez que é constatada forte correlação entre os diversos descritores de comunidades, como apresentado no Anexo F, escolheu-se enfatizar, nas análises seguintes, apenas três destes descritores: índice de diversidade de Shannon $\left(H^{\prime}\right)$, número de indivíduos $(N)$, e número de grupos tróficos $(G T)$. A correlação entre $H^{\prime}$ e $N$ não é significante. As demais correlações, apesar de significantes, são relativamente baixas em comparação às de outros pares de descritores. O objetivo de trabalhar com estes descritores é o de estudar aspectos distintos das amostras, de potencial relevância biológica. 


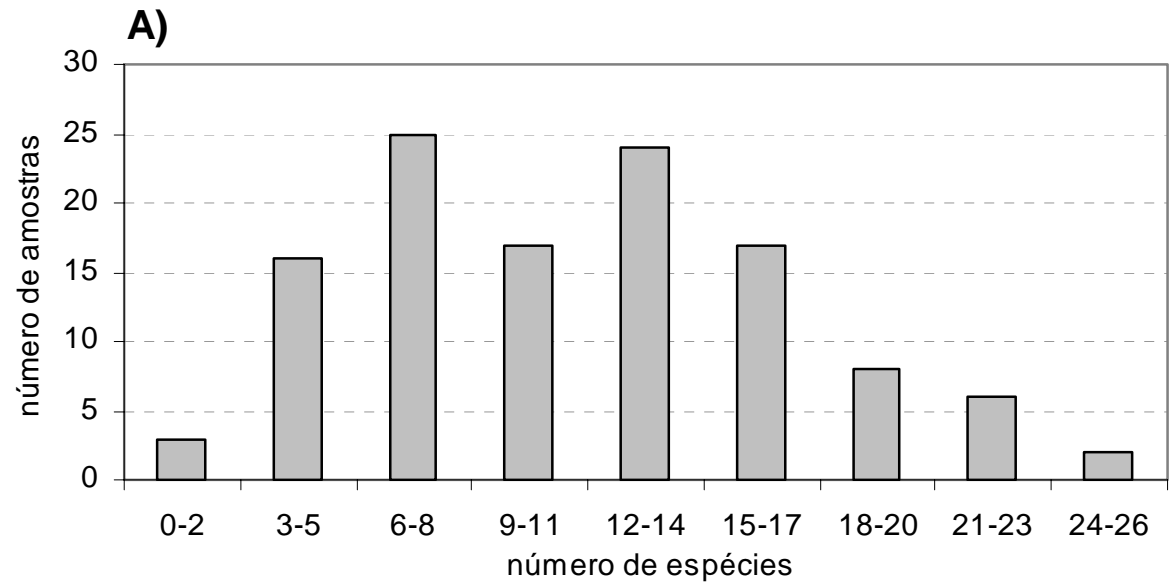

B)

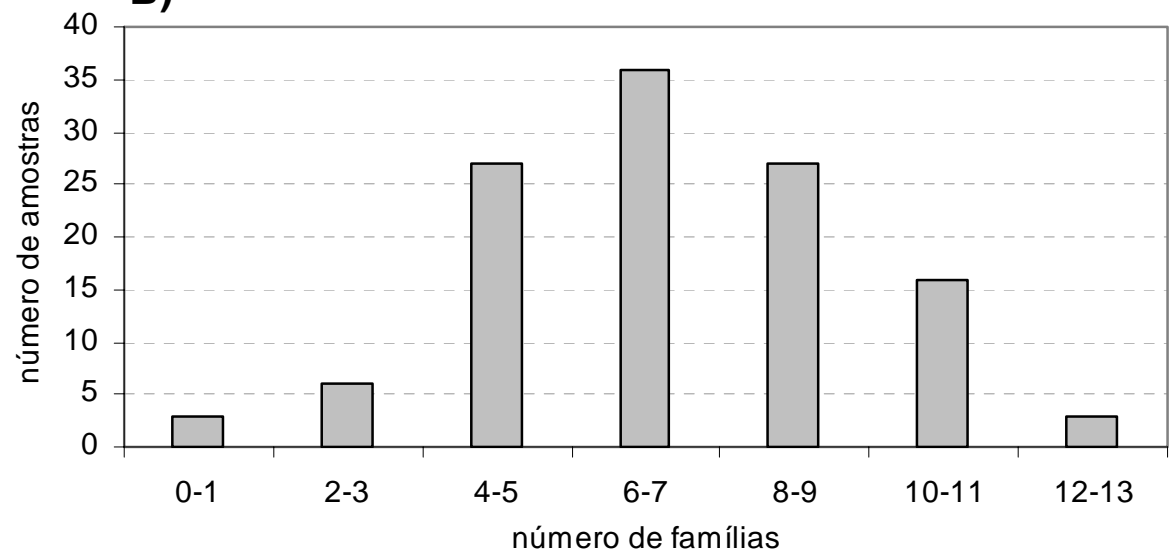

C)

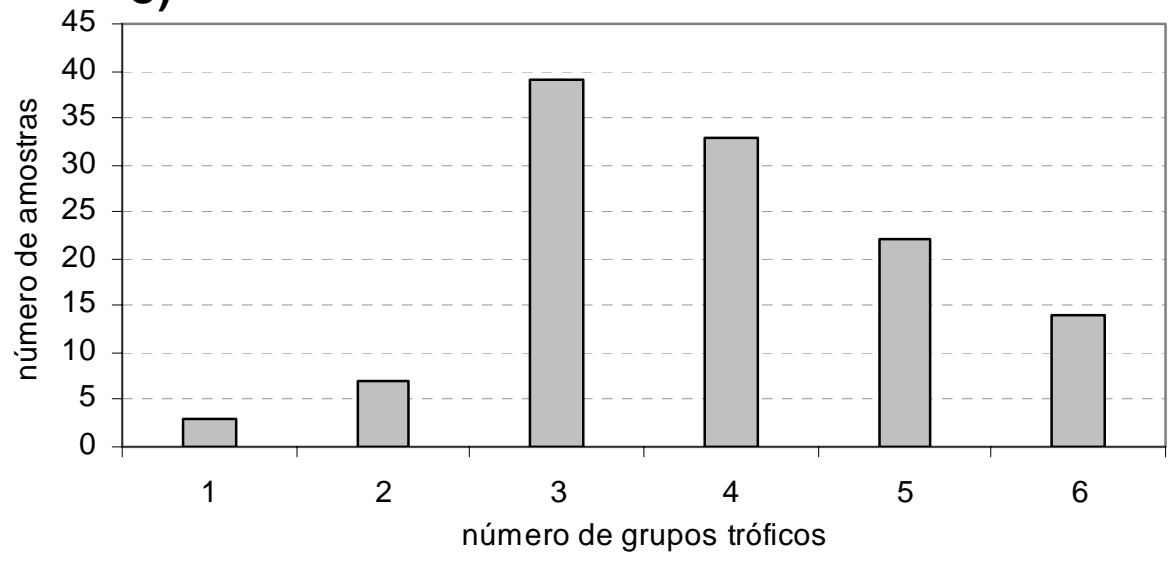

Figura 20 - Distribuições de freqüência de ocorrências do número de espécies (A), número de famílias (B) e número de grupos tróficos (C) em 118 amostras de peixes de riachos da Bacia do Rio Corumbataí, SP 
A)

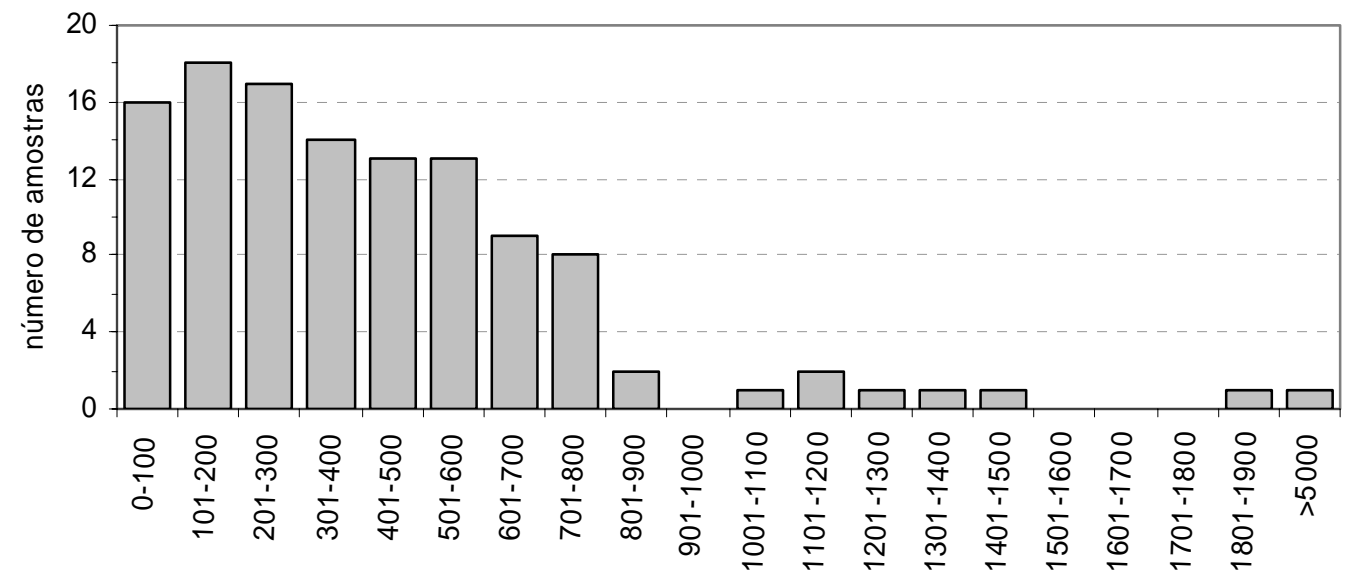

número de indivíduos

B)

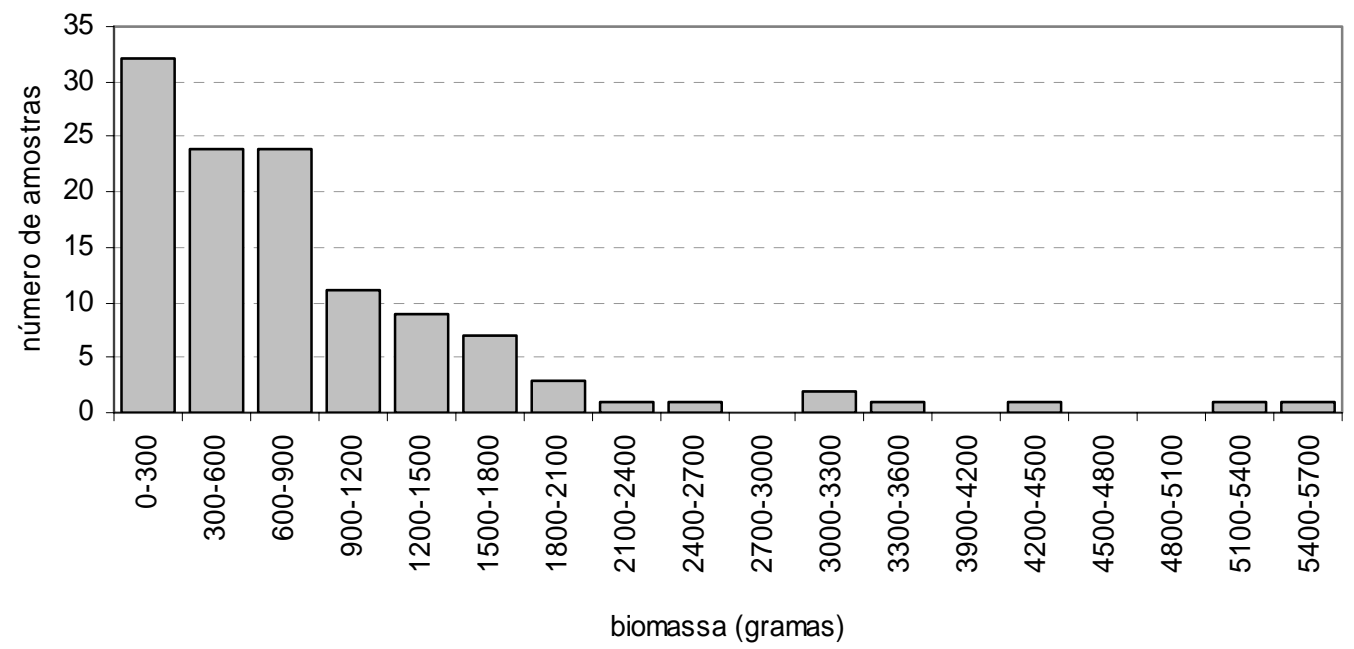

Figura 21 - Distribuições de freqüência de ocorrência do número de indivíduos (A), e biomassa total (B), de 118 amostras de peixes de riachos da Bacia do Rio Corumbataí, SP 


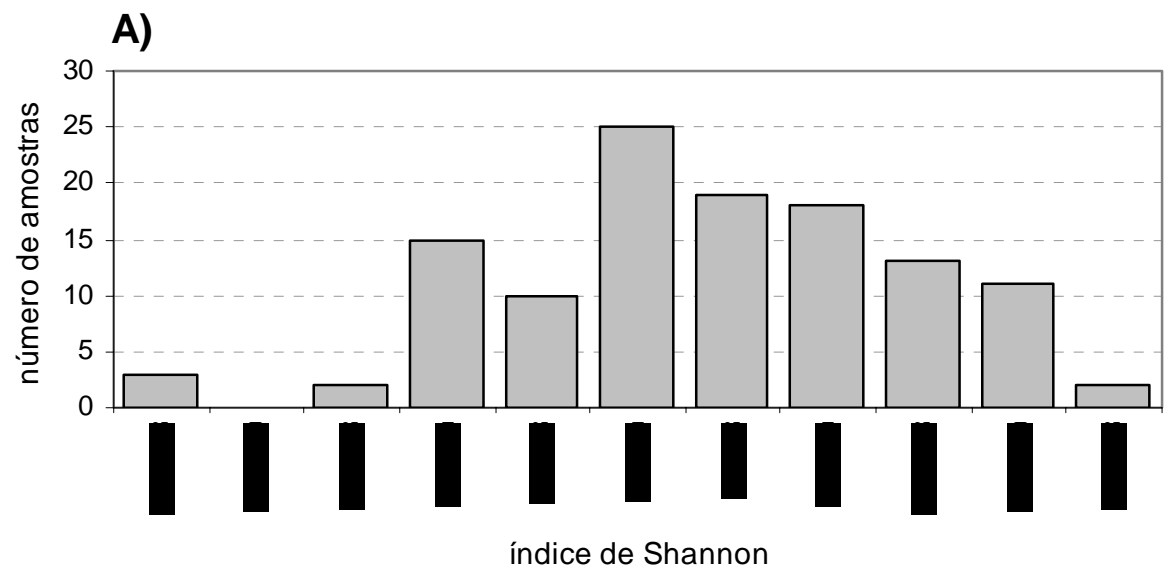

B)
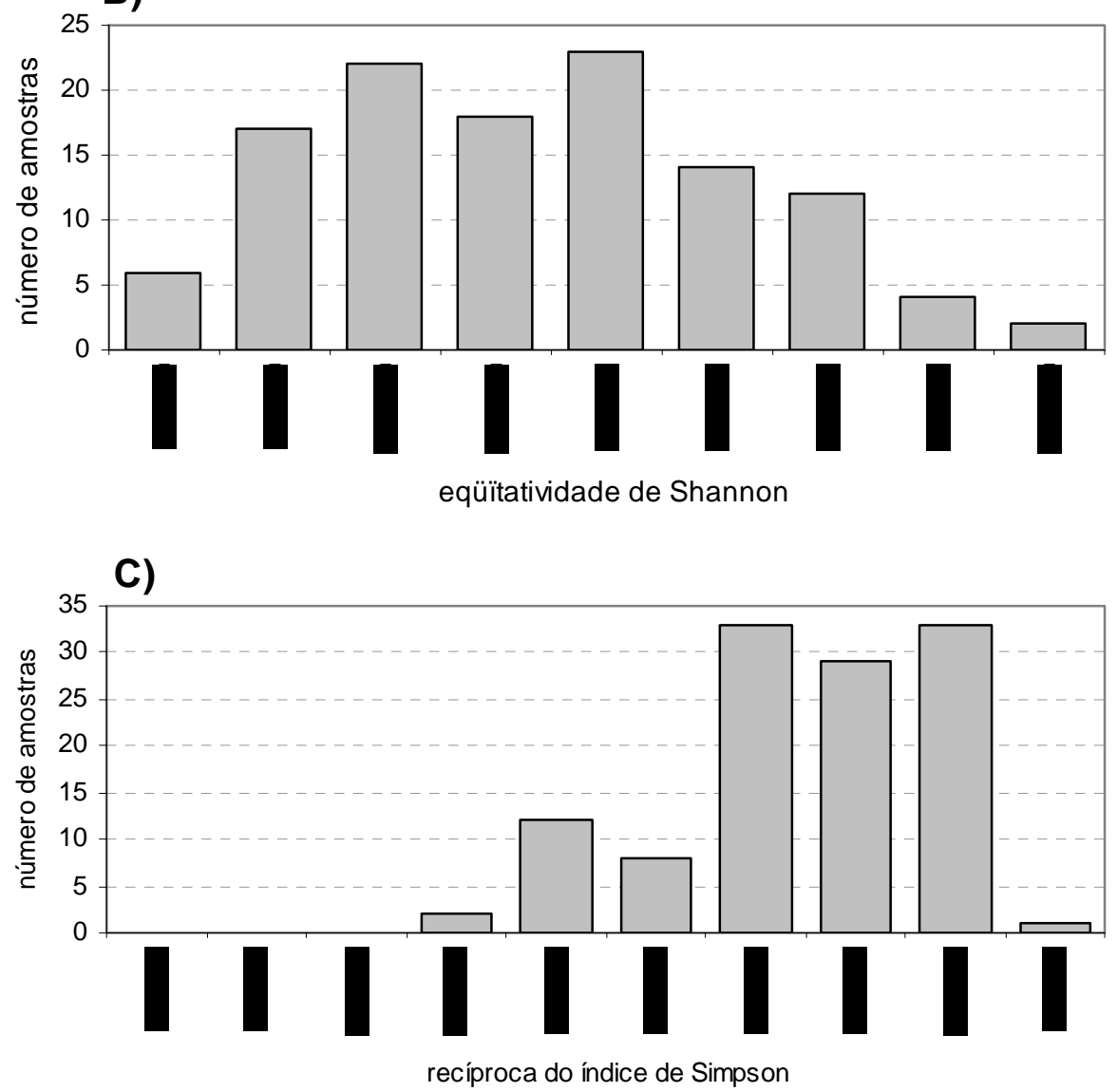

Figura 22 - Distribuições de freqüência de ocorrência do índice de Shannon (A), índice de eqüitatividade de Shannon (B) e a recíproca do índice de Simpson (C) em 118 amostras de peixes de riachos da Bacia do Rio Corumbataí, SP 


\subsubsection{Similaridade entre as comunidades}

$\mathrm{Na}$ Figura 23 e na Tabela 23 são mostrados os resultados da análise de agrupamento realizada para o conjunto de amostras da estação chuvosa, com 60 amostras.

As amostras obtidas na estação chuvosa são claramente ordenadas em quatro grupos principais, constituindo dois pares de grupos de tamanhos semelhantes entre si (grupos I e II com 21 e 19 amostras, respectivamente, e grupos III e IV com 10 amostras cada). A primeira grande divisão na Figura 23 separa o grupo I dos demais. Aparentemente, é caracterizada uma associação entre espécies presentes em riachos de gradiente elevado, em oposição às cabeceiras em áreas de menor declividade, assunto tratado no item 4.3.3. Todos os grupos são facilmente caracterizados pela dominância de pelo menos uma espécie. Os grupos I e II destacam-se pelo número de espécies exclusivas e também por espécies constantes exclusivas a eles, como Corumbataia cuestae e Trichomycterus sp. no grupo I, Astyanax aff. eigenmanniorum, A. altiparanae e Bryconamericus sp. 1 entre outros, no grupo II. Os grupos III e IV não possuem espécies exclusivas e são mais bem caracterizados por suas espécies dominantes.

A análise de agrupamento para as amostras obtidas nas estações secas apresentou cinco grupos definidos pelo patamar de $40 \%$ de dissimilaridade, portanto, pouco mais complexo que o grupo das amostras da estação chuvosa.

Tal como para as amostras obtidas na estação chuvosa, a Figura 24 mostra uma segregação entre dois grupos de amostras, um deles, com 20 amostras (grupo I) parece estar constituído de associações típicas de regiões de gradiente acentuado, em oposição à outra divisão, contendo as demais amostras (grupos II-V). Este assunto será retomado no item 4.3.3. 


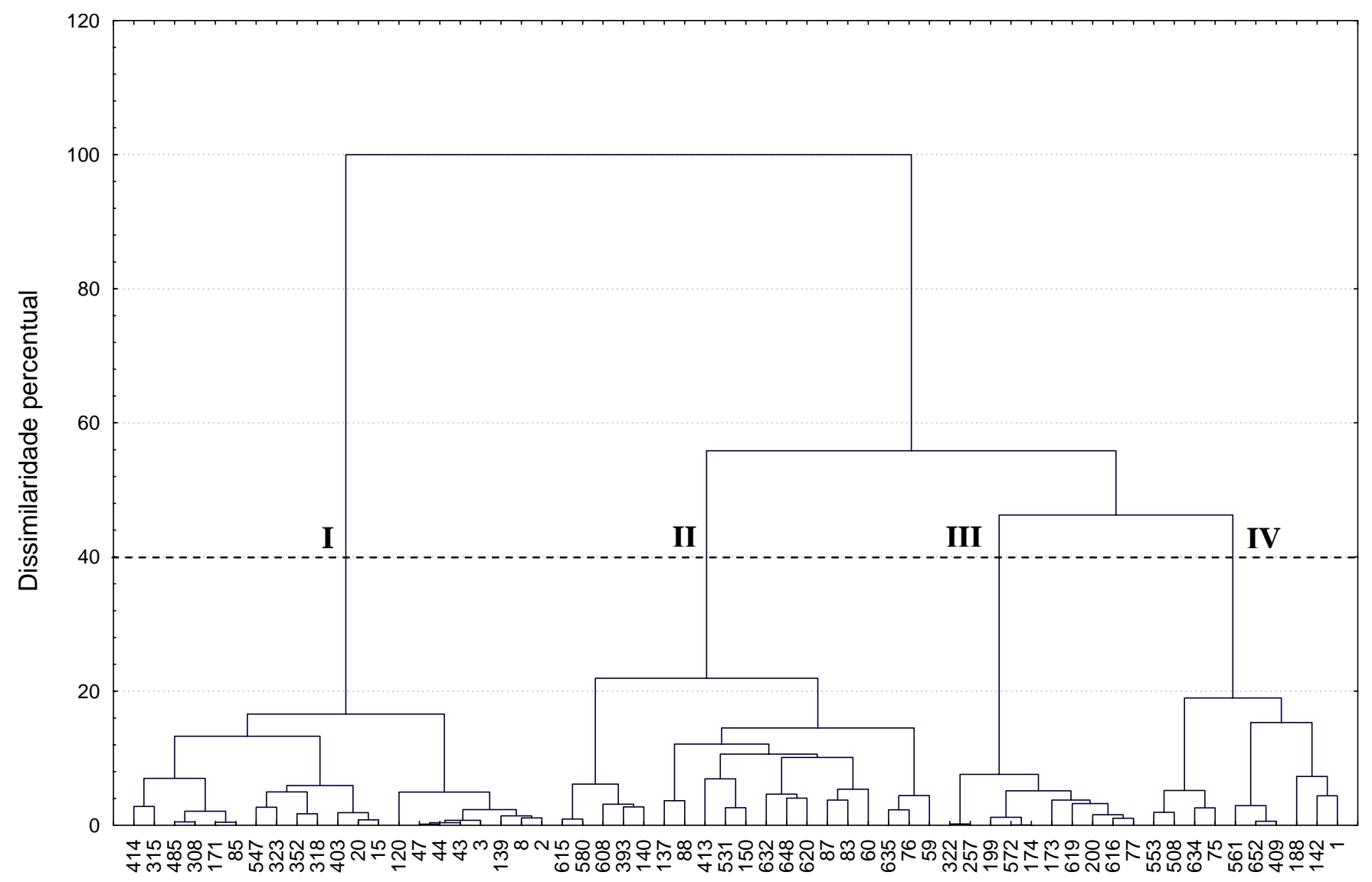

Figura 23 - Resultado da análise de agrupamento de 60 amostras de peixes de riachos (identificadas pelo ID da microbacia no eixo x) obtidas nas estações chuvosas de 2003 e 2004, na Bacia do Rio Corumbataí, SP. Medida de dissimilaridade: recíproca do índice de Morisita-Horn. Método de ligação: Ward. Destacou-se o corte em 40 \% de dissimilaridade, e os grupos definidos por este corte (I, II, III e IV) 
Tabela 23. Espécies exclusivas, constantes e dominantes em cada um dos grupos contidos na Figura 23. Os grupos referem-se às 60 amostras obtidas nas estações chuvosas de 2003 e 2004

\begin{tabular}{|c|c|c|c|c|}
\hline & $\mathrm{I}$ & II & III & IV \\
\hline Exclusivas & $\begin{array}{l}\text { Astyanax sp. } 1 \\
\text { Characidium gomesi } \\
\text { Heptapteridae gen. n. sp. n. } \\
\text { Neoplecostomus paranensis }\end{array}$ & $\begin{array}{l}\text { Astyanax sp. } 2 \\
\text { Astyanax sp. } 3 \\
\text { Corydoras flaveolus } \\
\text { Cyphocharax sp. } \\
\text { Hoplosternum littorale } \\
\text { Hyphessobrycon eques } \\
\text { Oreochromis niloticus } \\
\text { Piabina argentea } \\
\text { Steindachnerina insculpta }\end{array}$ & - & - \\
\hline Constantes & $\begin{array}{l}\text { Astyanax paranae } \\
\text { Corumbataia cuestae } \\
\text { Hypostomus ancistroides } \\
\text { Trichomycterus sp. }\end{array}$ & $\begin{array}{l}\text { Astyanax paranae } \\
\text { Astyanax altiparanae } \\
\text { Astyanax aff. eigenmanniorum } \\
\text { Bryconamericus sp. } 1 \\
\text { Geophagus brasiliensis } \\
\text { Hoplias malabaricus } \\
\text { Hypostomus ancistroides } \\
\text { Imparfinis schubarti } \\
\text { Poecilia reticulata } \\
\text { Rhamdia cf. quelen }\end{array}$ & $\begin{array}{l}\text { Astyanax paranae } \\
\text { Characidium cf. zebra } \\
\text { Hypostomus ancistroides } \\
\text { Imparfinis schubarti } \\
\text { Phalloceros caudimaculatus } \\
\text { Rhamdia cf. quelen }\end{array}$ & $\begin{array}{l}\text { Astyanax paranae } \\
\text { Hypostomus ancistroides }\end{array}$ \\
\hline Dominantes & $\begin{array}{l}\text { Corumbataia cuestae } \\
\text { Trichomycterus sp. }\end{array}$ & Astyanax altiparanae & Imparfinis schubarti & Phalloceros caudimaculatus \\
\hline
\end{tabular}


Pelos critérios definidos acima, os grupos I, III e IV são bem caracterizados por espécies exclusivas, sendo seis listadas para o grupo I, três para o III e uma para o grupo I. Todos os grupos (I-V) são caracterizados por uma espécie dominante (duas no caso do grupo I) e por espécies constantes exclusivas aos grupos I, III e IV. Estes três últimos grupos estão bem caracterizados pelos três critérios (Tabela 24).

A Tabela 25 mostra a concordância entre os grupos encontrados nas análises conduzidas para ambas as estações. Nota-se que os grupos I, III e IV da estação chuvosa assemelham-se em maior ou menor grau aos grupos I, II e V da estação seca. O grupo II da estação chuvosa assemelha-se à soma dos grupos III e IV da estação seca. A tabela indica o caráter parcialmente dinâmico destas associações, pois a freqüência com que cada amostra ocorreu dentro do mesmo grupo em ambas as estações foi de cerca de 80 $\%$.

A Tabela 26 também trata do perfil dos agrupamentos obtidos, ilustrando as médias do número de espécies e de indivíduos de cada um dos grupos obtidos. Desta tabela, destacam-se o grupo II, na estação chuvosa, e o grupo III na estação seca, com diversidade e número de grupos tróficos mais elevados, e acima das médias dos demais grupos. Na estação seca, o grupo III destaca-se pelo número de indivíduos, mas trata-se de um valor inflacionado pela amostra 393, contendo 5.114 indivíduos (v. Discussão).

Deste ponto em diante, é assumido que ocorrem quatro agrupamentos em termos de similaridade entre as comunidades estudadas, ou seja, esta diversidade apresenta um padrão interno discreto, que pode ser verificada em termos de constituição e abundância de seus constituintes. O perfil destes agrupamentos em relação às variáveis do meio ambiente levantadas neste estudo são apresentadas nos itens 4.3 e 4.4 . 


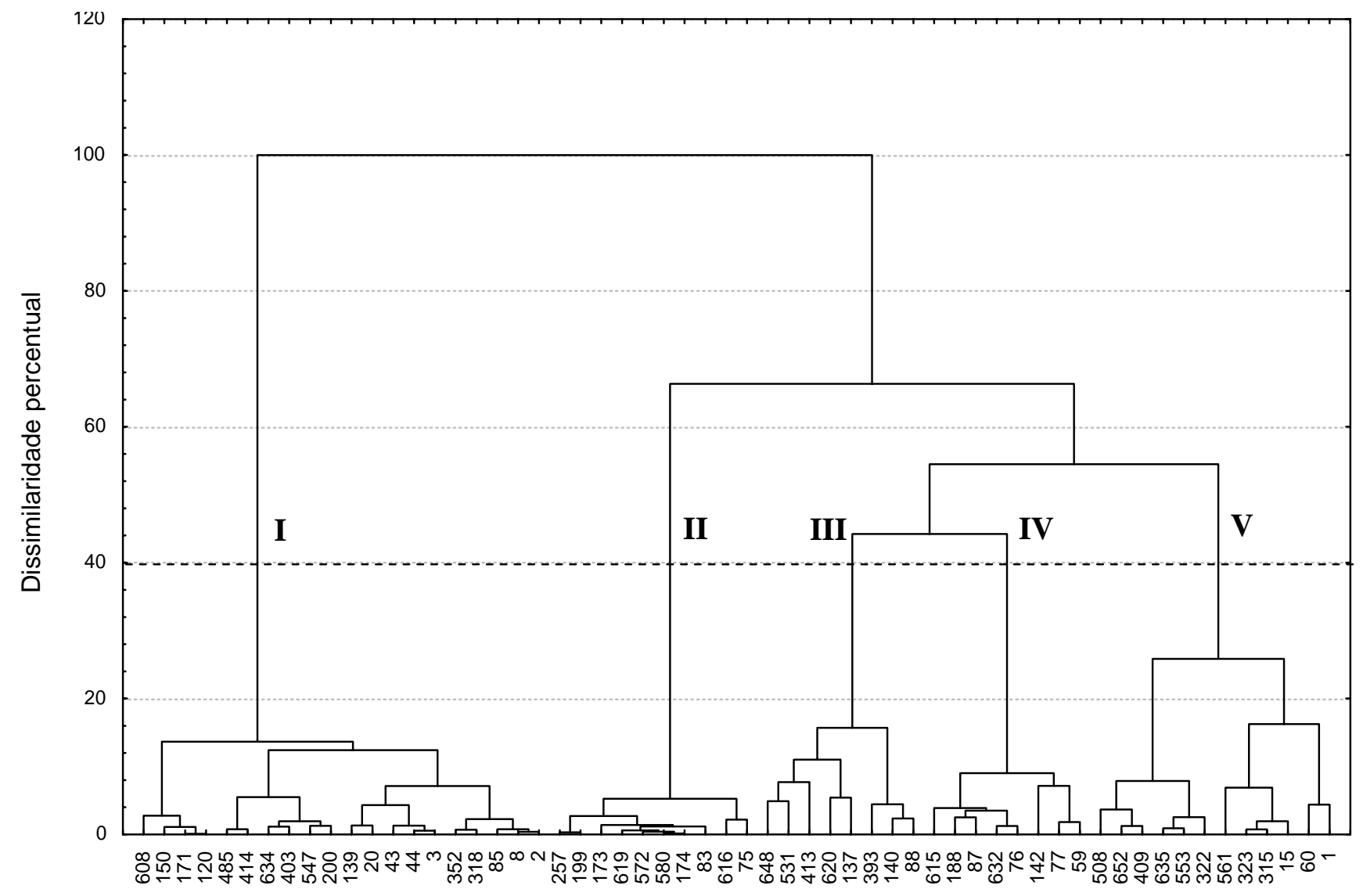

Figura 24 - Resultado da análise de agrupamento de 58 amostras de peixes de riachos (identificadas pelo ID da microbacia no eixo x) obtidas nas estações secas de 2003 e 2004, na Bacia do Rio Corumbataí, SP. Medida de dissimilaridade: recíproca do índice de Morisita-Horn. Método de ligação: Ward. Destacou-se o corte em 40 \% de dissimilaridade, e os grupos definidos por este corte (I, II, III, IV e V) 
Tabela 24. Espécies exclusivas, constantes e dominantes em cada um dos grupos contidos na Figura 24. Os grupos referem-se às 58 amostras obtidas nas estações secas de 2003 e 2004

\begin{tabular}{|c|c|c|c|c|c|}
\hline & I & II & III & IV & $\mathrm{V}$ \\
\hline Exclusivos & $\begin{array}{l}\text { Apareiodon ibitiensis } \\
\text { Astyanax sp. } 1 \\
\text { Characidium gomesi } \\
\text { Heptapteridae gen. n. sp. n. } \\
\text { Neoplecostomus paranensis }\end{array}$ & - & $\begin{array}{l}\text { Bryconamericus sp. } 2 \\
\text { Hyphessobrycon eques } \\
\text { Planaltina sp. }\end{array}$ & Serrapinnus sp. & - \\
\hline Constantes & $\begin{array}{l}\text { Astyanax paranae } \\
\text { Corumbataia cuestae } \\
\text { Hypostomus ancistroides } \\
\text { Trichomycterus sp. }\end{array}$ & $\begin{array}{l}\text { Astyanax paranae } \\
\text { Rhamdia cf. quelen } \\
\text { Imparfinis schubarti }\end{array}$ & $\begin{array}{l}\text { Astyanax paranae } \\
\text { Astyanax altiparanae } \\
\text { Astyanax aff. eigenmanniorum } \\
\text { Bryconamericus sp. } 1 \\
\text { Geophagus brasiliensis } \\
\text { Gymnotus cf. carapo } \\
\text { Hoplias malabaricus } \\
\text { Hypostomus ancistroides } \\
\text { Imparfinis schubarti } \\
\text { Rhamdia cf. quelen } \\
\text { Serrapinnus heterodon } \\
\text { Synbranchus marmoratus }\end{array}$ & $\begin{array}{l}\text { Astyanax paranae } \\
\text { Geophagus brasiliensis } \\
\text { Hypostomus ancistroides } \\
\text { Imparfinis schubarti } \\
\text { Poecilia reticulata }\end{array}$ & Astyanax paranae \\
\hline Dominantes & $\begin{array}{l}\text { Corumbataia cuestae } \\
\text { Trichomycterus sp. }\end{array}$ & Imparfinis schubarti & Serrapinnus heterodon & Poecilia reticulata & $\begin{array}{l}\text { Phalloceros } \\
\text { caudimaculatus }\end{array}$ \\
\hline
\end{tabular}


Tabela 25. Concordância entre os grupos obtidos através da análise de agrupamento realiza para o conjuntos de amostras obtidas nas estações chuvosas secas. As amostras que não encontram pares entre os grupos foram destacadas em negrito. É apresentado o número total de amostras (\# amostras), o número de amostras em comum entre os grupos (comum) e a porcentagem de comuns em relação ao total (\% comum)

\begin{tabular}{|c|c|c|c|c|c|c|c|c|c|}
\hline grupos & $\begin{array}{c}\text { I } \\
\text { chuva }\end{array}$ & $\begin{array}{c}\text { I } \\
\text { seca }\end{array}$ & $\begin{array}{c}\text { II } \\
\text { chuva }\end{array}$ & $\begin{array}{c}\text { III } \\
\text { seca }\end{array}$ & $\begin{array}{c}\text { IV } \\
\text { seca }\end{array}$ & $\begin{array}{c}\text { III } \\
\text { chuva }\end{array}$ & $\begin{array}{c}\text { II } \\
\text { seca }\end{array}$ & $\begin{array}{l}\text { IV } \\
\text { chuva }\end{array}$ & $\begin{array}{c}\mathrm{V} \\
\text { seca }\end{array}$ \\
\hline & 2 & 2 & 59 & 88 & 59 & 77 & 75 & 1 & 1 \\
\hline & 3 & 3 & 60 & 137 & 76 & 173 & 83 & 75 & 15 \\
\hline & 8 & 8 & 76 & 140 & 77 & 174 & 173 & 142 & 60 \\
\hline & 15 & 20 & 83 & 393 & 87 & 199 & 174 & 188 & 315 \\
\hline & 20 & 43 & 87 & 413 & 142 & 200 & 199 & 409 & 322 \\
\hline & 43 & 44 & 88 & 531 & 188 & 257 & 257 & 508 & 323 \\
\hline & 44 & 85 & 137 & 620 & 615 & 322 & 572 & 553 & 409 \\
\hline & 47 & 120 & 140 & 648 & 632 & 572 & 580 & 561 & 508 \\
\hline & 85 & 139 & 150 & & & 616 & 616 & 634 & 553 \\
\hline & 120 & 150 & 393 & & & 619 & 619 & 652 & 561 \\
\hline & 139 & 171 & 413 & & & & & & 635 \\
\hline & 171 & 200 & 531 & & & & & & 652 \\
\hline & 308 & 318 & 580 & & & & & & \\
\hline & 315 & 352 & 608 & & & & & & \\
\hline & 318 & 403 & 615 & & & & & & \\
\hline & 323 & 414 & 620 & & & & & & \\
\hline & 352 & 485 & 632 & & & & & & \\
\hline & 403 & 547 & 635 & & & & & & \\
\hline & 414 & 608 & 648 & & & & & & \\
\hline & 485 & 634 & & & & & & & \\
\hline & 547 & & & & & & & & \\
\hline \# amostras & 21 & 20 & 19 & 8 & 8 & 10 & 10 & 10 & 12 \\
\hline comum & - & 16 & - & - & 13 & - & 8 & - & 6 \\
\hline$\%$ comum & - & 76,2 & - & - & 68,4 & - & 80,0 & - & 50,0 \\
\hline
\end{tabular}


Tabela 26. Número total de amostras, média e desvio-padrão do número de indivíduos $(N)$, índice de Shannon ( $\left.H^{\prime}\right)$ e número de grupos tróficos $(G T)$ dos grupos obtidos nas análises de agrupamento realizadas para dois conjuntos de amostras de peixes de riachos (chuva e seca) na Bacia do Rio Corumbataí, SP

\begin{tabular}{llcccc}
\hline Estações & Grupos & $\begin{array}{c}\mathrm{n}^{\circ} \mathrm{de} \\
\text { amostras }\end{array}$ & $N$ & $H^{\prime}$ & $G T$ \\
\hline chuvosas & I & 21 & $403,48 \pm 270,57$ & $1,52 \pm 0,43$ & $3,24 \pm 0,44$ \\
& II & 19 & $539,58 \pm 378,68$ & $2,11 \pm 0,34$ & $5,11 \pm 0,88$ \\
& III & 10 & $450,70 \pm 376,02$ & $1,39 \pm 0,44$ & $4,00 \pm 0,94$ \\
& IV & 10 & $226,80 \pm 287,21$ & $1,38 \pm 0,66$ & $3,50 \pm 1,51$ \\
secas & I & 20 & $420,05 \pm 319,38$ & $1,41 \pm 0,48$ & $3,40 \pm 0,88$ \\
& II & 10 & $527,80 \pm 402,76$ & $1,19 \pm 0,46$ & $3,80 \pm 1,14$ \\
& III & 8 & $1.123,13 \pm$ & $2,08 \pm 0,47$ & $5,25 \pm 1,16$ \\
& IV & 8 & $363,75 \pm 255,26$ & $1,64 \pm 0,35$ & $4,50 \pm 0,76$ \\
& V & 12 & $227,67 \pm 212,87$ & $1,29 \pm 0,54$ & $3,00 \pm 1,13$ \\
\hline
\end{tabular}

\subsection{Comunidades de peixes de riachos e habitat}

\subsubsection{Uso e cobertura do solo}

\section{Cobertura dominante}

A Tabela 27 mostra o resumo das estatísticas (média e desvio padrão) dos grupos de amostras referentes às coberturas dominantes: canaviais, pastagens e matas nativas, nas estações chuvosas e secas de 2003 e 2004. 
Tabela 27. Número de amostras (\#), média e desvio padrão do número de indivíduos $(N)$, índice de diversidade de Shannon $\left(H^{\prime}\right)$ e número de grupos tróficos (GT) por amostra de peixes de riachos da Bacia do Rio Corumbataí, SP, tomadas nas estações chuvosas e secas dos anos 2003 e 2004

\begin{tabular}{lcccc}
\hline Estações & Descritorese & Canaviais & Pastagens & Matas nativas \\
\hline Chuvosas & $\#$ & 19 & 16 & 11 \\
& $N$ & $482,53 \pm 308,58$ & $523,69 \pm 452,73$ & $336,73 \pm 277,81$ \\
& $H^{\prime}$ & $1,63 \pm 0,63$ & $1,92 \pm 0,46$ & $1,53 \pm 0,40$ \\
& $G T$ & $4,21 \pm 1,13$ & $4,63 \pm 1,31$ & $3,36 \pm 0,92$ \\
Secas & & & & \\
& $H$ & 19 & 15 & 11 \\
& $N$ & $445,26 \pm 347,63$ & $777,40 \pm 1.238,06$ & $344,09 \pm 368,50$ \\
& $H^{\prime}$ & $1,36 \pm 0,59$ & $1,76 \pm 0,41$ & $1,44 \pm 0,38$ \\
& $G T$ & $3,84 \pm 1,26$ & $4,53 \pm 1,06$ & $3,27 \pm 1,01$ \\
\hline
\end{tabular}

Como a tabela mostra, há enorme variação entre os descritores considerando estes grupos. Os gráficos box-plot das Figuras 25 e 26 ilustram a distribuição destes descritores, considerando a mediana, a amplitude, e as distribuições de freqüências do segundo e terceiro quartis de cada um dos grupos considerados.

Uma análise de variância sobre cada uma dos descritores citados na Tabela 27 foi conduzida, considerando os conjuntos das amostras tomadas nas estações chuvosas e secas. A Tabela 28 mostra o resumo das estatísticas destes testes. 
A)

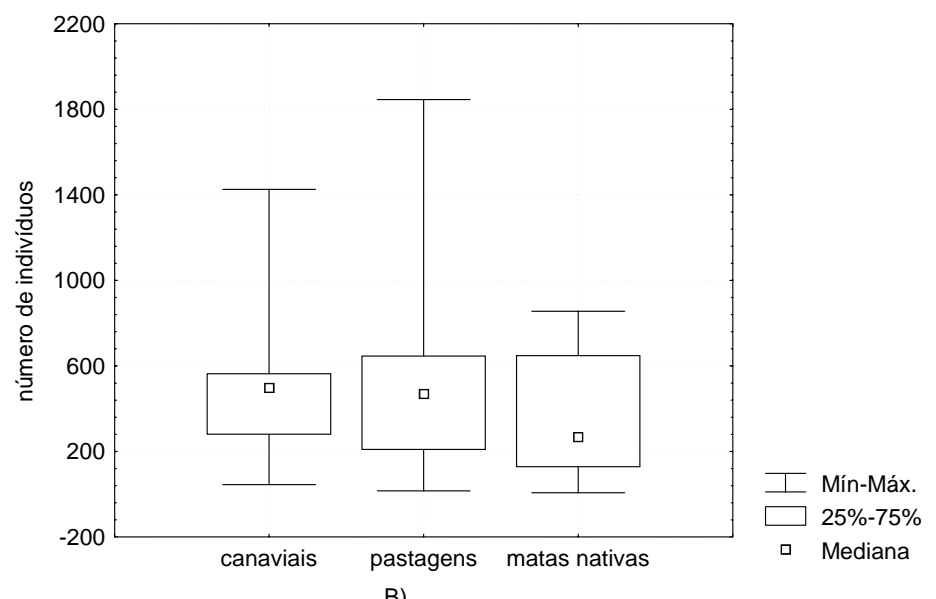

B)

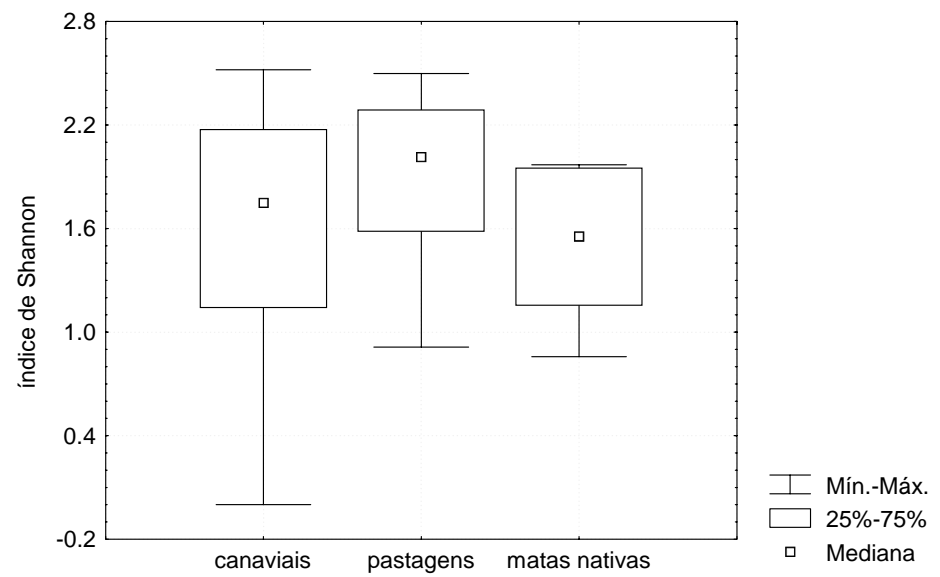

C)

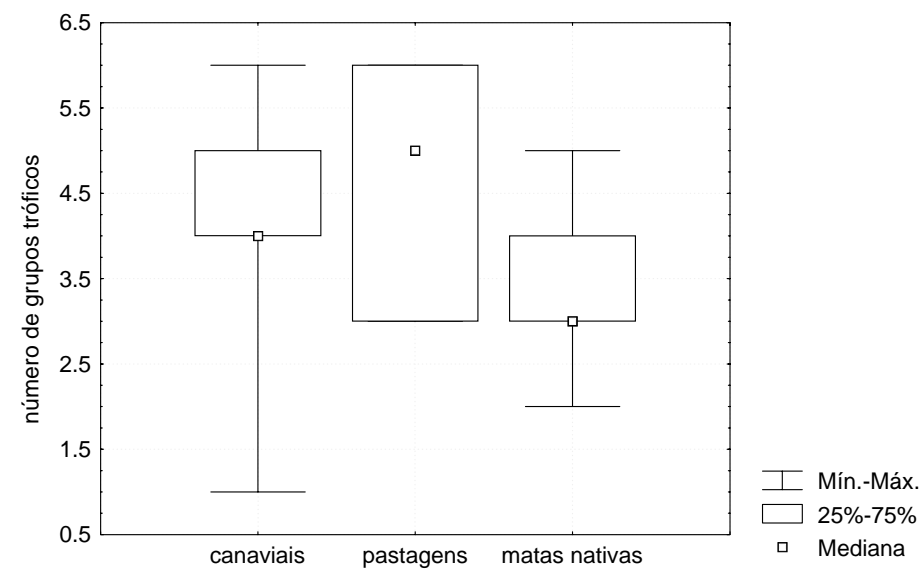

Figura 25 - Gráficos box-plot para as amostras das estações chuvosas, ilustrando a distribuição do número de indivíduos (A), índice de Shannon (B) e número de grupos tróficos $(\mathrm{C})$, referente à cobertura do solo dominante na microbacia (variável CD) 
A)
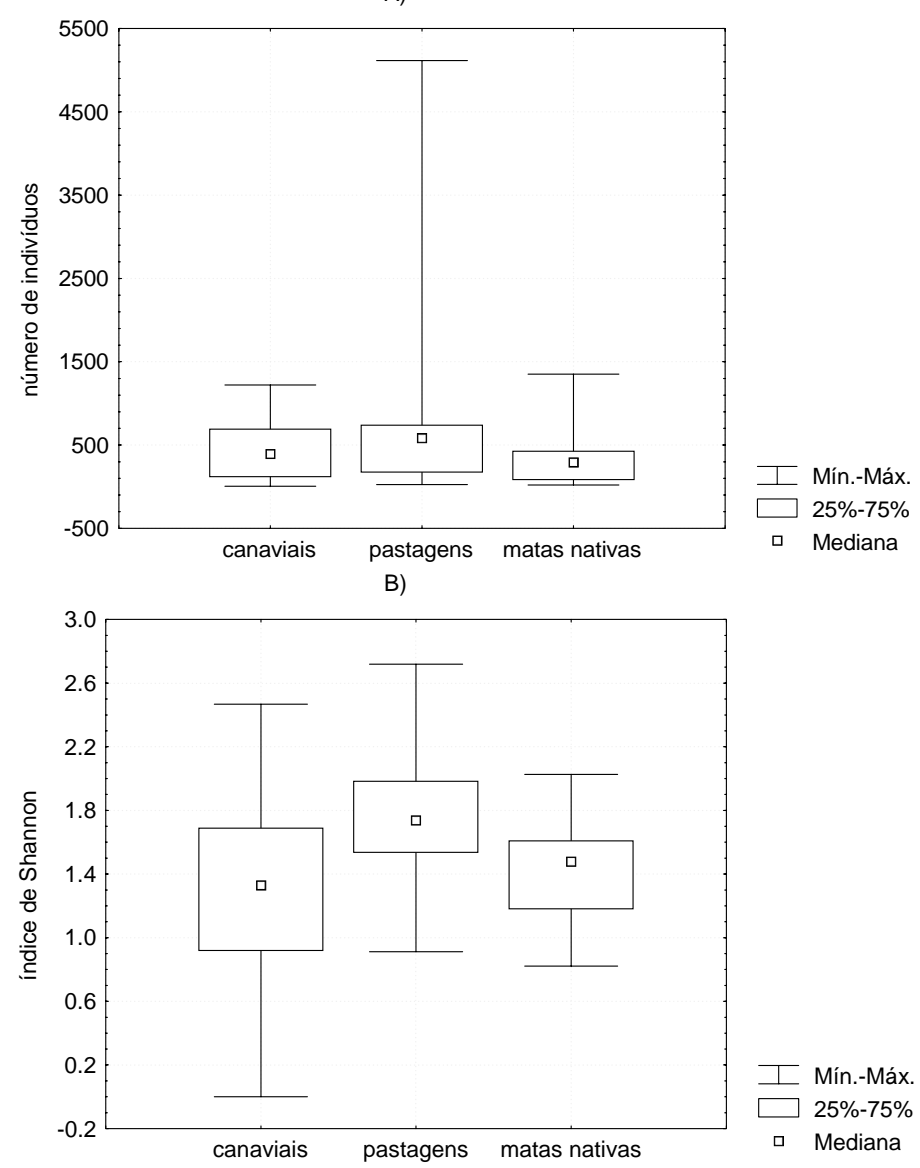

C)

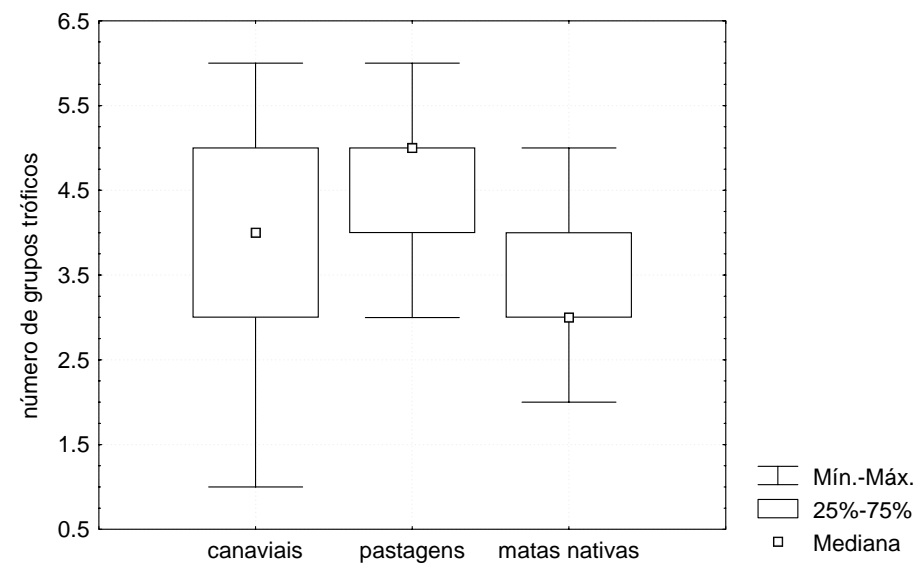

Figura 26 - Gráficos box-plot para as amostras das estações secas, ilustrando a distribuição do número de indivíduos (A), índice de Shannon (B) e número de grupos tróficos (C), referente à cobertura do solo dominante na microbacia (variável CD) 
Tabela 28. Resumo das estatísticas da análise de variância (tipo 1) para 46 e 45 amostras de peixes de riachos da Bacia do Rio Corumbataí, SP, coletadas nas estações chuvosas e secas de 2003 e 2004, respectivamente

\begin{tabular}{|c|c|c|c|c|c|c|c|c|c|}
\hline & & \multicolumn{3}{|c|}{ Cobertura dominante } & \multicolumn{3}{|c|}{ Erro } & \multirow[b]{2}{*}{$F$} & \multirow[b]{2}{*}{$p$} \\
\hline & & $\mathrm{gl}$ & SQ & QM & $\mathrm{gl}$ & SQ & QM & & \\
\hline \multirow{3}{*}{ 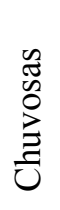 } & $N$ & 2 & $241.516,62$ & $120.758,31$ & 43 & $5.560 .152,36$ & $129.305,87$ & 0,93 & 0,40 \\
\hline & $H^{\prime}$ & 2 & 1,18 & 0,59 & 43 & 11,98 & 0,28 & 2,12 & 0,13 \\
\hline & $G T$ & 2 & 10,48 & 5,24 & 43 & 57,45 & 1,34 & 3,92 & 0,03 \\
\hline \multirow{3}{*}{ 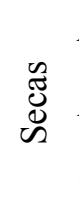 } & $N$ & 2 & $1.434 .642,12$ & $717.321,06$ & 42 & $24.992 .250,19$ & $595.053,58$ & 1,21 & 0,31 \\
\hline & $H^{\prime}$ & 2 & 1,44 & 0,72 & 42 & 10,09 & 0,24 & 2,99 & $\underline{0,06}$ \\
\hline & $G T$ & 2 & 10,36 & 5,18 & 42 & 54,44 & 1,30 & 4,00 & 0,03 \\
\hline
\end{tabular}

$\mathrm{gl}$ = graus de liberdade, $\mathrm{SQ}$, soma de quadrados, $\mathrm{QM}$ quadrados médios, $N=$ número de indivíduos, $H^{\prime}$ = índice de diversidade de Shannon e $G T$ = número de grupos tróficos. Valor em negrito: teste significativo, mas não há normalidade dos dados. Valor sublinhado: probabilidade marginalmente significante

Da Tabela 28, observa-se que não existem diferenças significativas entre as coberturas dominantes para a maior parte dos descritores, a não ser em relação ao número de grupos tróficos por amostra. Neste caso, o grupo das microbacias de matas nativas apresentam média significativamente menor que os demais grupos, conforme a Tabela 27. A variável GT não apresenta distribuição normal dos dados mas a versão não paramétrica do teste indica, do mesmo modo, diferenças significativas entre os grupos (Kruskal-Wallis ANOVA, $H=6,91,2 \mathrm{gl}, p=0,03(n=46)$ para as estações chuvosas e $H=7,50,2 \mathrm{gl}, p=0,02(n=45)$ para o conjunto das secas). Em relação ao índice de Shannon no conjunto e amostras das estações chuvosas, o valor é marginalmente significante. Aqui, do mesmo modo, o grupo de amostras em matas nativas são menos diversos, destacando-se as pastagens como as mais diversas. 
Note-se que para as versões paramétricas do teste (Tabela 28) o poder do teste para os descritores considerados é demasiado baixo (inferior a $46 \%$ ), indicando elevada probabilidade de se aceitar a hipótese de diferença de variâncias erroneamente.

Os resultados indicam que a cobertura dominante da microbacia parece influenciar a quantidade de grupos tróficos de peixes de riachos. Existem valores marginais de $p$ que indicam uma possível interação entre cobertura dominante do solo e diversidade das comunidades de peixes. Entretanto deve ser notado, em geral, uma baixa diferenciação entre os tratamentos considerados os descritores das comunidades. Algumas hipóteses foram levantadas, e serão apresentadas em detalhes na Discussão.

Vegetação ripária: pasto × matas nativas

O detalhamento da posição relativa das matas em relação aos canais da microbacia é tratado nesta seção. As Figuras 27 e 28 e a Tabela 29 indicam estatísticas básicas dos grupos de amostras obtidos nas duas estações em relação às microbacia de pasto e às microbacias com quantidade significativa ( $>55 \%$ em área) de mata nativa ao redor de seus canais, e a Tabela 30, os resultados dos testes de comparação de médias entre os dois grupos, nas duas estações. 


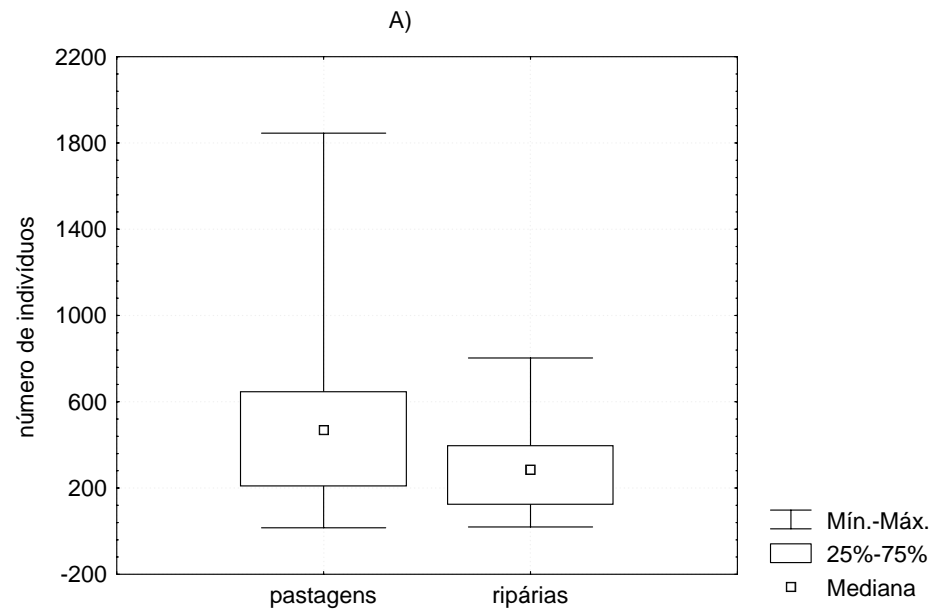

B)

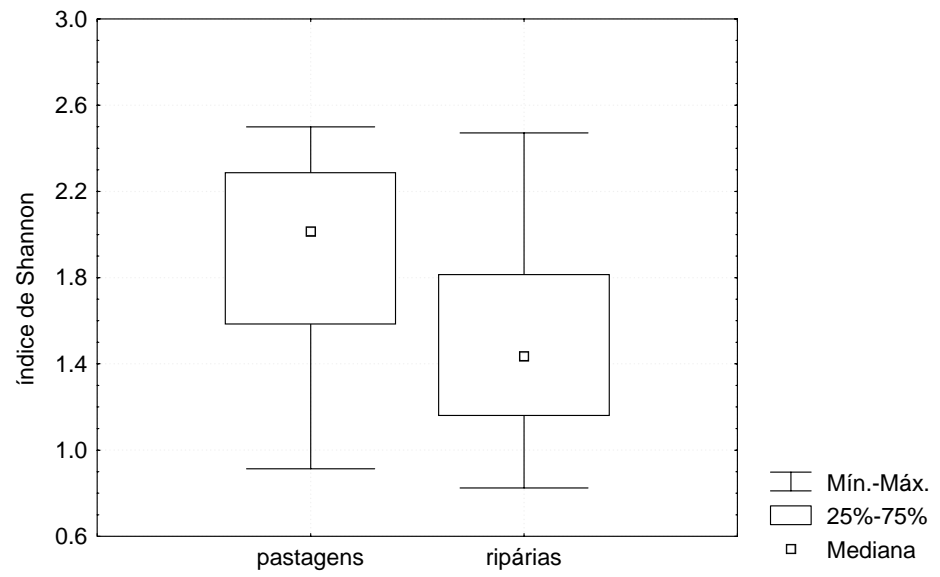

C)

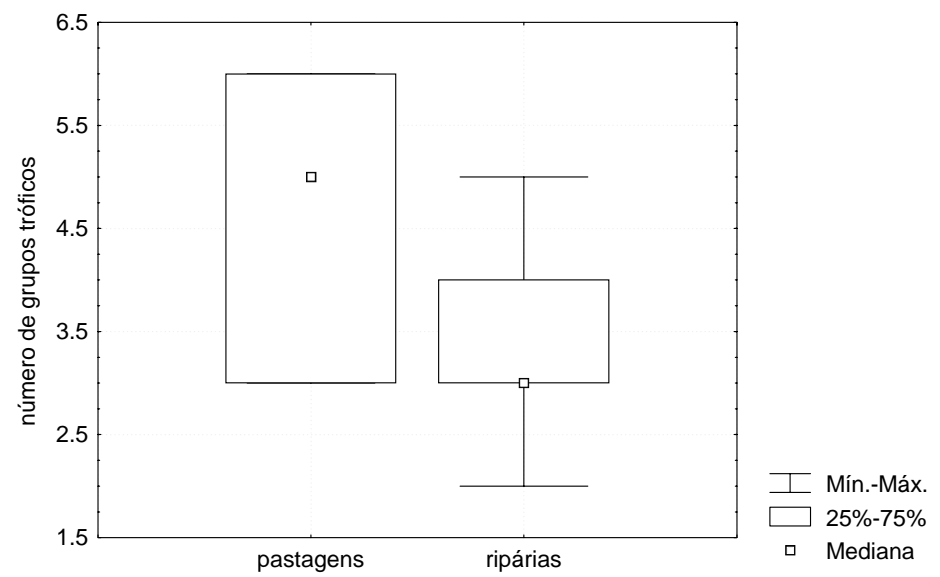

Figura 27 - Gráficos box-plot para o conjunto de amostras obtidas nas estações chuvosas, ilustrando a distribuição do número de indivíduos (A), índice de Shannon $(\mathrm{B})$ e número de grupos tróficos $(\mathrm{C})$ 


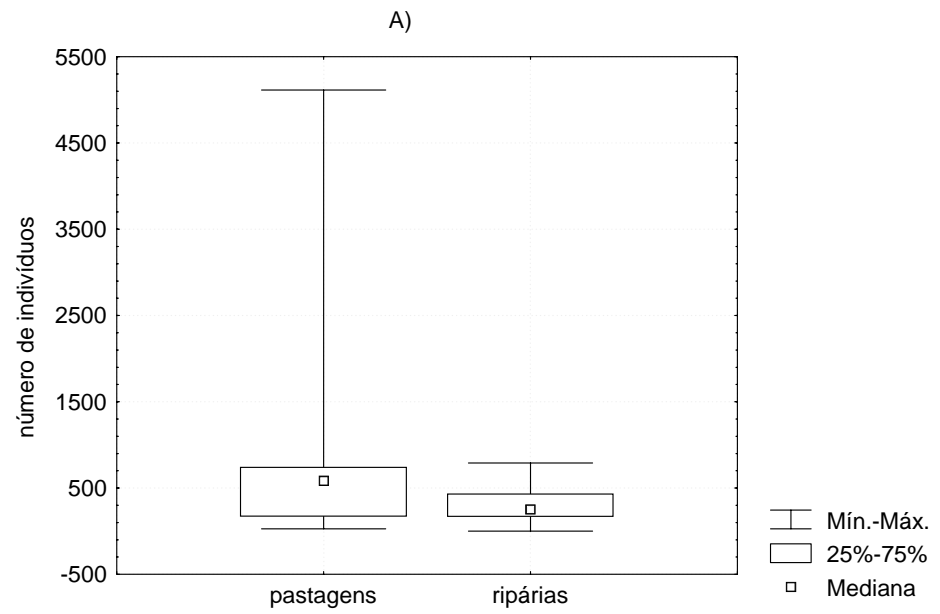

B)

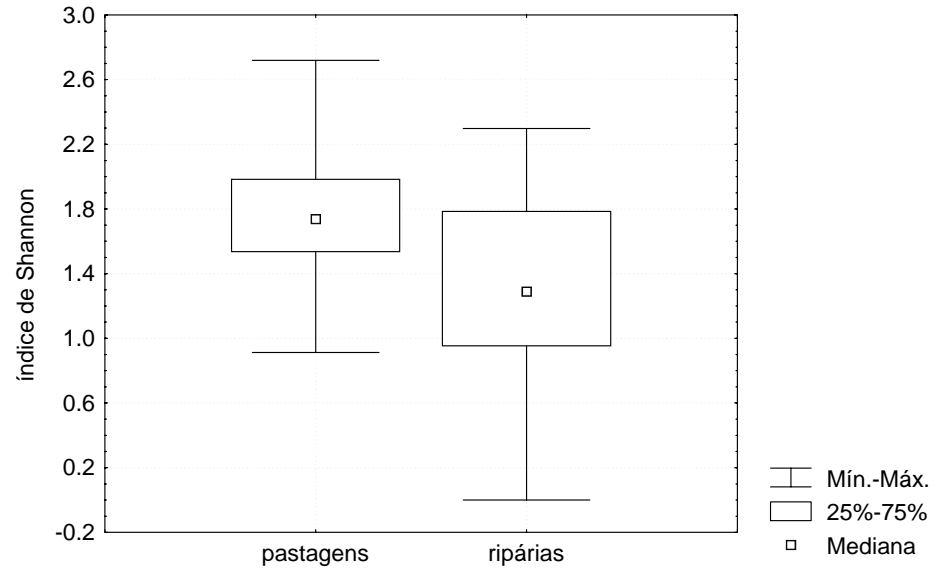

C)

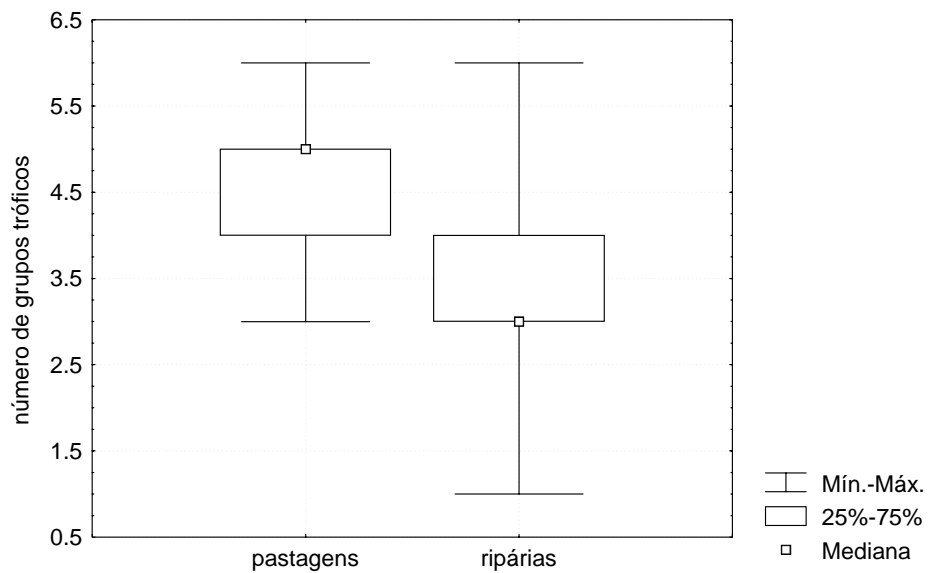

Figura 28 - Gráficos box-plot para o conjunto de amostras obtidas nas estações secas, ilustrando a distribuição do número de indivíduos (A), índice de Shannon (B) e número de grupos tróficos $(\mathrm{C})$ 
Tabela 29. Número de amostras (\#), média e desvio padrão do número de indivíduos $(N)$, do índice de diversidade de Shannon $\left(H^{\prime}\right)$, e número de grupos tróficos (GT) por amostra de peixes de riachos da Bacia do Rio Corumbataí, SP, tomadas na estações chuvosas e secas dos anos 2003 e 2004

\begin{tabular}{lccc}
\hline Estações & Descritores & Pastagens & Ripárias \\
\hline Chuvosas & $\#$ & 16 & 14 \\
& $N$ & $523,69 \pm 452,73$ & $303,50 \pm 223,20$ \\
& $H^{\prime}$ & $1,92 \pm 0,46$ & $1,53 \pm 0,54$ \\
& $G T$ & $4,63 \pm 1,31$ & $3,50 \pm 0,94$ \\
Secas & & & \\
& $\#$ & 15 & 13 \\
& $N$ & $777,40 \pm 1.238,06$ & $338,46 \pm 237,24$ \\
& $H$ & $1,76 \pm 0,41$ & $1,32 \pm 0,61$ \\
& $G T$ & $4,53 \pm 1,06$ & $3,31 \pm 1,18$ \\
\hline
\end{tabular}


Tabela 30. Resumo das estatísticas de análise do teste $t$ para comparação de descritores de riqueza e diversidade entre microbacias de pastagens e ripárias da Bacia do Rio Corumbataí, SP, amostrados durante as estações chuvosas e secas de 2003 e 2004

\begin{tabular}{ccccc}
\hline Estações & Descritores & $t$ & $\mathrm{gl}$ & $p$ \\
\hline Chuvosas & $N$ & 1,65 & 28 & 0,11 \\
& $H^{\prime}$ & 2,10 & 28 & $0,05^{*}$ \\
& $G T$ & 2,67 & 28 & $\mathbf{0 , 0 1}$ \\
\multirow{5}{*}{ Secas } & $N$ & 1,26 & 26 & 0,22 \\
& $H^{\prime}$ & 2,27 & 26 & $0,03^{*}$ \\
& $G T$ & 2,89 & 26 & $\mathbf{0 , 0 1}$ \\
\hline
\end{tabular}

$\mathrm{gl}=$ graus de liberdade. Valores de $p$ marcados com * são significativos a $5 \%$. Valor em negrito: teste significativo, mas não há normalidade dos dados. $N=$ número de indivíduos, $H^{\prime}=$ índice de diversidade de Shannon, $G T$ = número de grupos tróficos

As análises indicam diferenças significativas para os descritores $H^{\prime}$ e $G T$, em ambas as estações. O poder dos testes realizados sobre as variáveis é variado: menor que $30 \%$ para $N$ (ambas as estações), $36 \%$ e $42 \%$ para $H^{\prime}$ (estações chuvosas e secas), e entre $64 \%$ e $67 \%$ sobre a variável GT (estações chuvosas e secas, respectivamente). As demais variáveis apresentaram-se como significativas, porém não apresentaram normalidade dos dados. O teste $t$ é bastante robusto quanto a desvios de normalidade (Zar, 1999). Todavia, versões não-paramétricas do teste para o descritor GT também indicaram diferenças significantes das medianas da variável nos grupos pastagens e ripárias (Teste de Mann-Whitney, $U=57,50$ e $p=0,02$ para as estações chuvosas e $U=$ 42,50 e $p=0,01$ para as estações secas).

De modo geral, pode-se afirmar que as microbacias que apresentam matas no entorno dos canais estudados são menos diversas, tanto quanto ao índice de diversidade de Shannon quanto ao número de grupos tróficos presentes, em média, nestes riachos. 
A vegetação na área de preservação permanente: total de riachos amostrados

Um derivação desta análise foi testar DB (categoria de uso ou cobertura do solo dominante na APP) através de análise de variância. Entre as 60 microbacias amostradas, ocorreram apenas o predomínio de canaviais, pastagens e matas nativas. O número de microbacias com predomínio de canaviais na APP foi bastante baixo (Tabela 31, Figuras 29 e 30$)$.

Tratando estas análises de variâncias como testes relaxados, afirmam-se interações significativas entre DB e $H^{\prime}$ e $G T$ nas estações chuvosas e secas, embora os testes apresentem baixo poder (Tabela 32). Testes não paramétricos sobre GT também indicam diferenças significativas entre os tratamentos (Kruskal-Wallis ANOVA, $H=$ 11,76, $2 \mathrm{gl}, p<0,01(n=58)$ para as estações secas e $H=7,15,2 \mathrm{gl}, p=0,03(n=60)$ para o conjunto das chuvosas). Curiosamente, ao contrário dos indícios apresentados na Tabela 28, as microbacias que têm canaviais em sua APP mostraram-se as de menor diversidade $\left(H^{\prime}\right)$ e número de grupos tróficos $(G T)$ (pastagens $\times$ matas nativas iguais, em todas as comparações). Isto implica num fator extra a ser ponderado nas discussões: os atributos testados da estrutura das comunidades de peixes podem não estar necessariamente, ou inteiramente, relacionados à ocorrência de ambiente florestal ou agrícola nas APP. 
Tabela 31. Número de amostras (\#), média e desvio padrão do número de indivíduos $(N)$, índice de diversidade de Shannon $\left(H^{\prime}\right)$ e número de grupos tróficos (GT) por amostra de peixes de riachos da Bacia do Rio Corumbataí, SP, tomadas nas estações chuvosas e secas dos anos 2003 e 2004, em relação à cobertura dominante na zona ripária, variável DB

\begin{tabular}{lcccc}
\hline Estações & Descritoress & Canaviais & Pastagens & Matas nativas \\
\hline Chuvosas & $\#$ & 3 & 27 & 30 \\
& $N$ & $201,00 \pm 187,49$ & $476,04 \pm 372,99$ & $401,47 \pm 310,40$ \\
& $H^{\prime}$ & $1,08 \pm 1,09$ & $1,82 \pm 0,47$ & $1,58 \pm 0,51$ \\
& $G T$ & $2,67 \pm 2,08$ & $4,44 \pm 1,12$ & $3,73 \pm 1,01$ \\
Secas & $\#$ & 3 & 26 & 29 \\
& $N$ & $225,00 \pm 226,44$ & $626,54 \pm 967,79$ & $391,07 \pm 326,25$ \\
& $H$ & $0,60 \pm 0,53$ & $1,59 \pm 0,46$ & $1,45 \pm 0,53$ \\
& $H$ & $2,00 \pm 1,00$ & $4,31 \pm 1,05$ & $3,52 \pm 1,15$ \\
\hline
\end{tabular}


A)

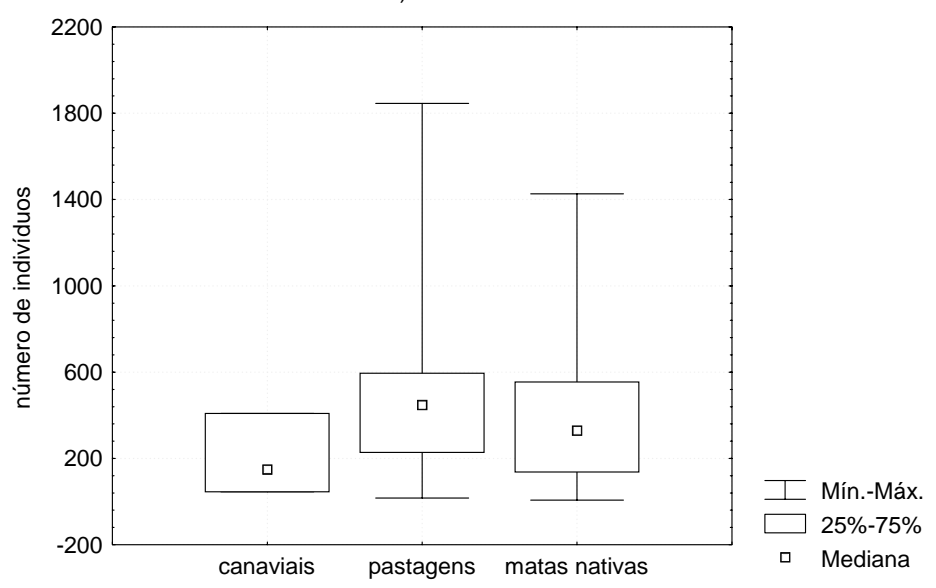

B)

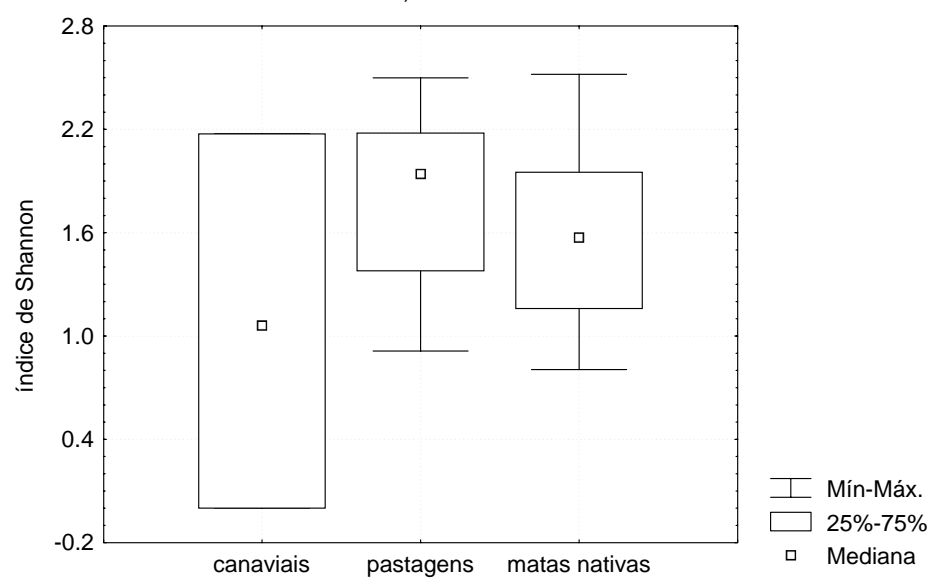

C)

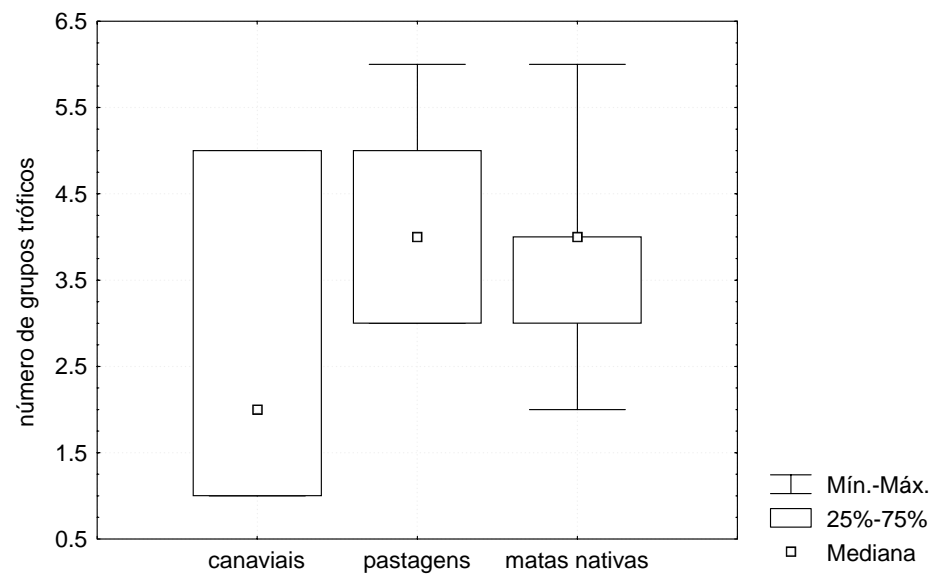

Figura 29 - Gráficos box-plot para o conjunto de amostras obtidas nas estações

chuvosas, ilustrando a distribuição do número de indivíduos (A), índice de Shannon $(B)$ e número de grupos tróficos $(C)$, em relação à variável DB 
A)

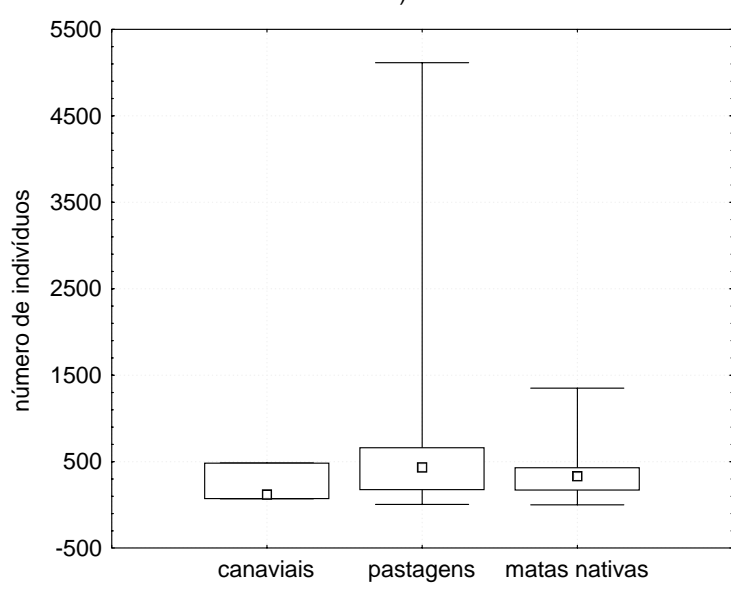

I Mín.-Máx $\square$ 25\%-75\%

B)

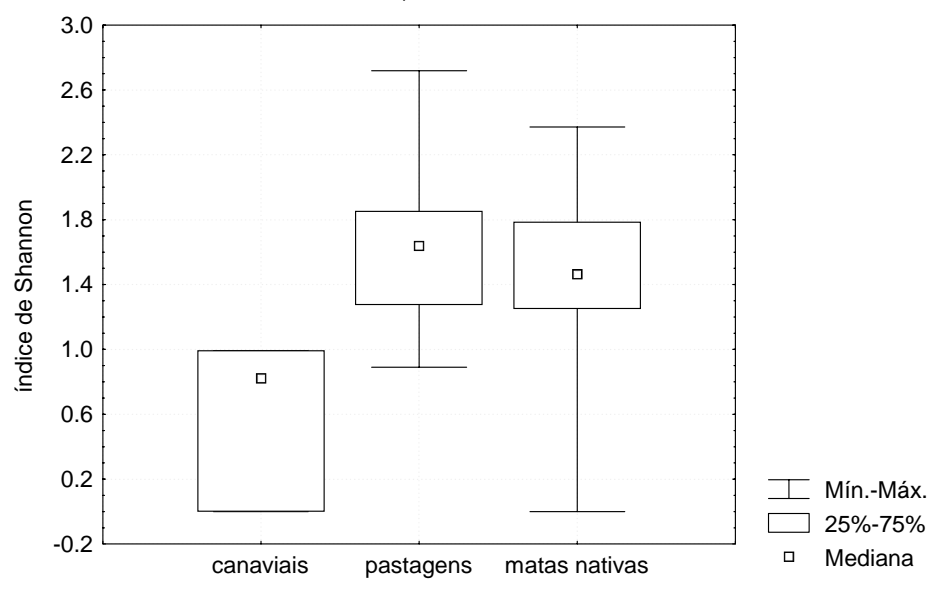

C)

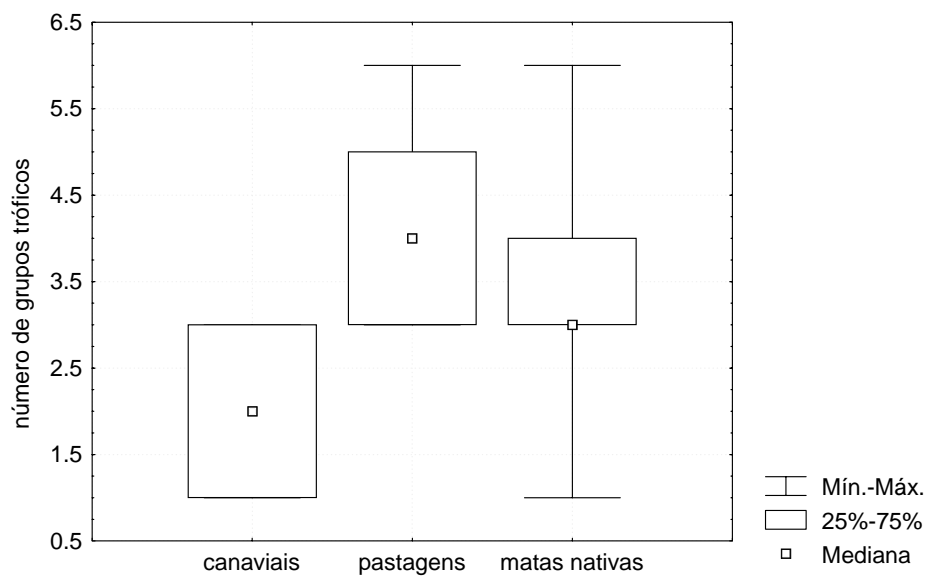

Figura 30 - Gráficos box-plot para o conjunto de amostras obtidas nas estações secas, ilustrando a distribuição do número de indivíduos (A), índice de Shannon (B) e número de grupos tróficos $(\mathrm{C})$, em relação à variável $\mathbf{D B}$ 
Tabela 32. Resumo das estatísticas da análise de variância (tipo 1) para 60 e 58 amostras de peixes de riachos da Bacia do Rio Corumbataí, SP, coletadas nas estações chuvosas e secas de 2003 e 2004, respectivamente, em relação à cobertura dominante na zona ripária, variável DB

\begin{tabular}{|c|c|c|c|c|c|c|c|c|c|}
\hline & & \multicolumn{3}{|c|}{ Cobertura dominante } & \multicolumn{3}{|c|}{ Erro } & \multirow[b]{2}{*}{$F$} & \multirow[b]{2}{*}{$p$} \\
\hline & & gl & SQ & QM & $\mathrm{gl}$ & SQ & QM & & \\
\hline \multirow{3}{*}{ 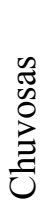 } & $N$ & 2 & $237.471,57$ & $118.735,79$ & 57 & 6.481.384, & $113.708,50$ & 1,04 & 0,36 \\
\hline & $H^{\prime}$ & 2 & 1.85 & 0.92 & 57 & 15,45 & 0,27 & 3,41 & $0,04 *$ \\
\hline & $G T$ & 2 & 12.80 & 6.40 & 57 & 71,20 & 1,25 & 5,12 & 0,01 \\
\hline \multirow{3}{*}{ 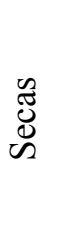 } & $N$ & 2 & $978.995,61$ & $489.497,80$ & 55 & $\begin{array}{c}26.498 .164 \\
,\end{array}$ & $481.784,81$ & 1,02 & 0,37 \\
\hline & $H^{\prime}$ & 2 & 2,65 & 1,32 & 55 & 13,69 & 0,25 & 5,32 & $0,01^{*}$ \\
\hline & $G T$ & 2 & 18,74 & 9,37 & 55 & 66,78 & 1,21 & 7,72 & 0,00 \\
\hline
\end{tabular}

$\mathrm{gl}=$ graus de liberdade, $\mathrm{SQ}$, soma de quadrados, $\mathrm{QM}$ quadrados médios, $N=$ número de indivíduos, $H^{\prime}$ = índice de diversidade de Shannon e $G T$ = número de grupos tróficos. Valor em negrito: teste significativo, mas sem normalidade dos dados. Valor marcado com asterisco: significantes a $5 \%$ e com normalidade dos dados

\section{Dominância de espécies e uso e cobertura do solo}

As duas sub-seções anteriores mostraram as diferenças entre as médias dos descritores de diversidade e abundância das microbacias agrupadas por cobertura do solo dominante na microbacia. Entretanto, tomadas as listas de ordenação de espécies em cada um dos quatro grupos considerados (cana, pasto, nativa e ripária), observa-se diferenças na importância das espécies em questão (Figuras 31, 32, 33 e 34).

A Tabela 33 compara as dez espécies mais importantes em termos de número de indivíduos em cada um dos grupos considerados, e o Anexo G mostra a lista completa das espécies acumuladas de cada um dos grupos em questão. Nota-se que destas, cinco são comuns aos quatro grupos, e quatro comuns a três. Ainda assim, a tabela indica que as microbacias de pastagem apresentam duas espécies exclusivas, Astyanax fasciatus e Serrapinnus heterodon, destacando-se das demais. Outras diferenças, entre espécies 
pouco menos abundantes, aparecem. Nota-se ainda que as microbacias de pastagem apresentaram um total de 52 espécies (e categorias) acumuladas, contra 42 nas microbacias em canaviais, 37 nas de predomínio de matas e 36 nas microbacias ripárias. Conta ainda com sete espécies exclusivas (três casos de identificação duvidosa). Entretanto, isto pode ser atribuído ao fato de que esta categoria de microbacia é a mais bem distribuída entre as sub-bacias e ocorre em diversas situações geológicas e de relevo. Isto pode favorecer o maior número de espécies, mesmo não sendo a categoria mais amostrada.

Nitidamente, as curvas de ordenação de pastagens e canaviais apresentam-se mais semelhantes entre si, tal como ocorre para a ordenação das microbacias de matas nativas e ripárias. Nas duas primeiras, há um decréscimo acentuado na importância das segunda e terceira espécies em ordem de importância, ao passo que esse decréscimo é menos rigoroso nas microbacias de maior porcentagem de ambiente florestal. As curvas de ordenação foram log-transformadas e ajustadas a um modelo linear. Os coeficiente de inclinação das retas $(b)$ obtidas foram dispostos na Tabela 34. A magnitude de $b$ pode ser relacionada diretamente à dominância das espécies mais abundantes. Deste modo, nota-se que o conjunto das comunidades de peixes que ocorrem nas microbacias ripárias são as que apresentam maior eqüitatividade - isto é, menor dominância - seguida do grupo das matas nativas, canaviais, e pastagens. A comparação entre as diferentes inclinações (Análise de Covariância), entretanto, indica que as diferenças não são significativas ( $F o b s=0,29$, menor que $\left.F c_{0,05(1), 3,159} \cong 2,67, p>0,25\right)$. 


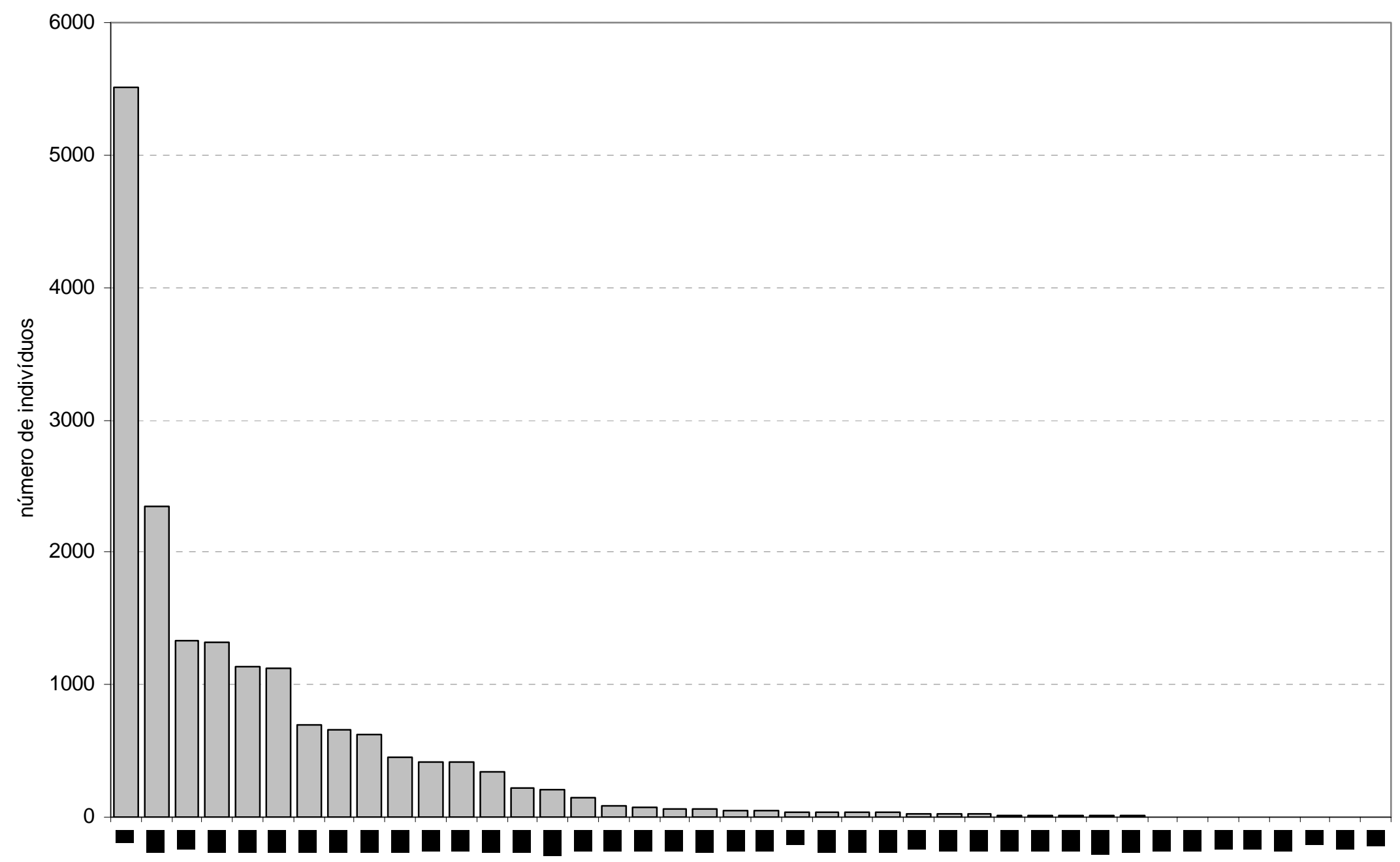

Figura 31 - Ranqueamento (ordenação) de espécies por importância em número de indivíduos de 38 amostras de peixes de riachos em microbacias de predomínio de canaviais, na Bacia do Rio Corumbataí, SP 


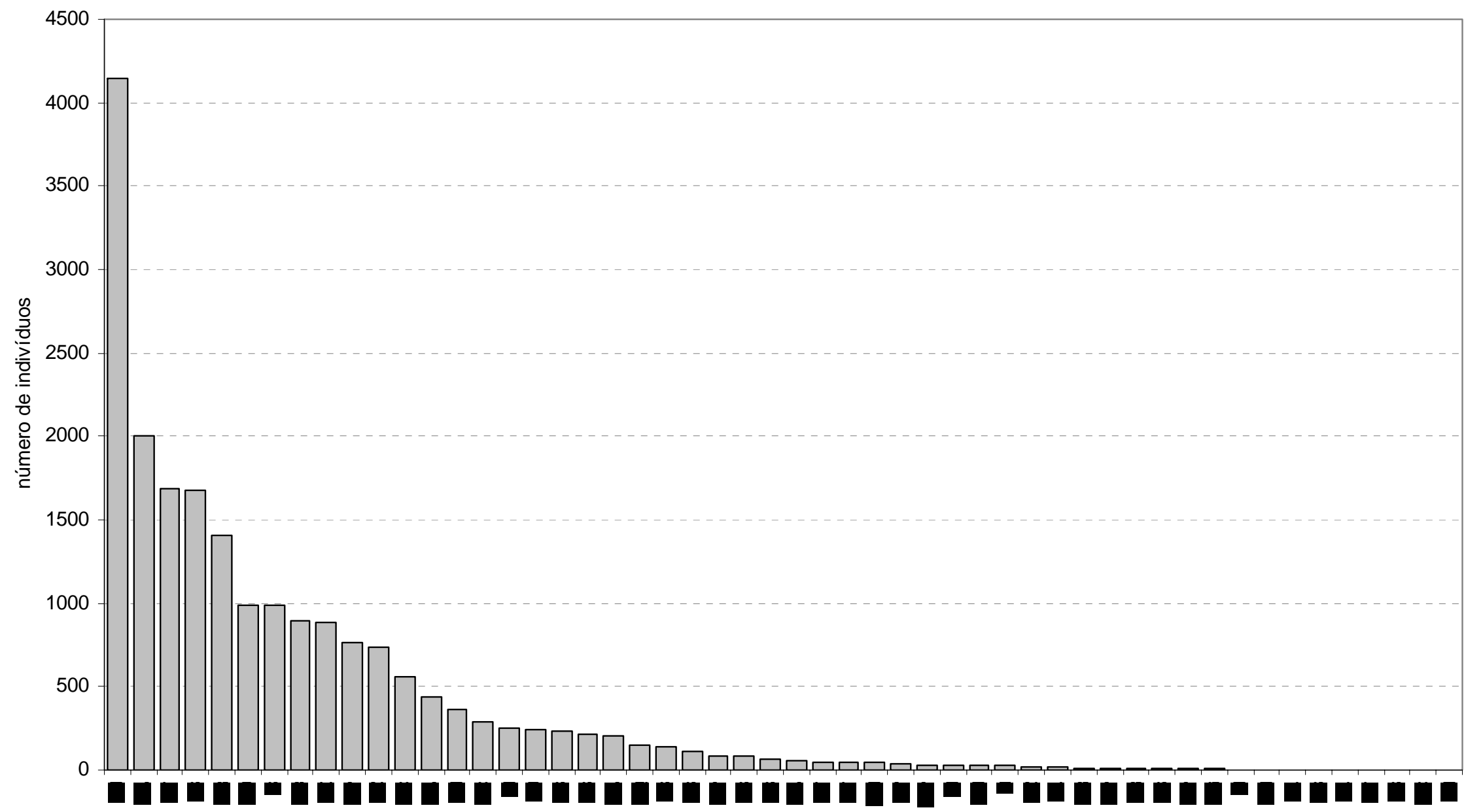

Figura 32 - Ranqueamento (ordenação) de espécies por importância em número de indivíduos de 31 amostras de peixes de riachos em microbacias de predomínio de pastagens, na Bacia do Rio Corumbataí, SP 


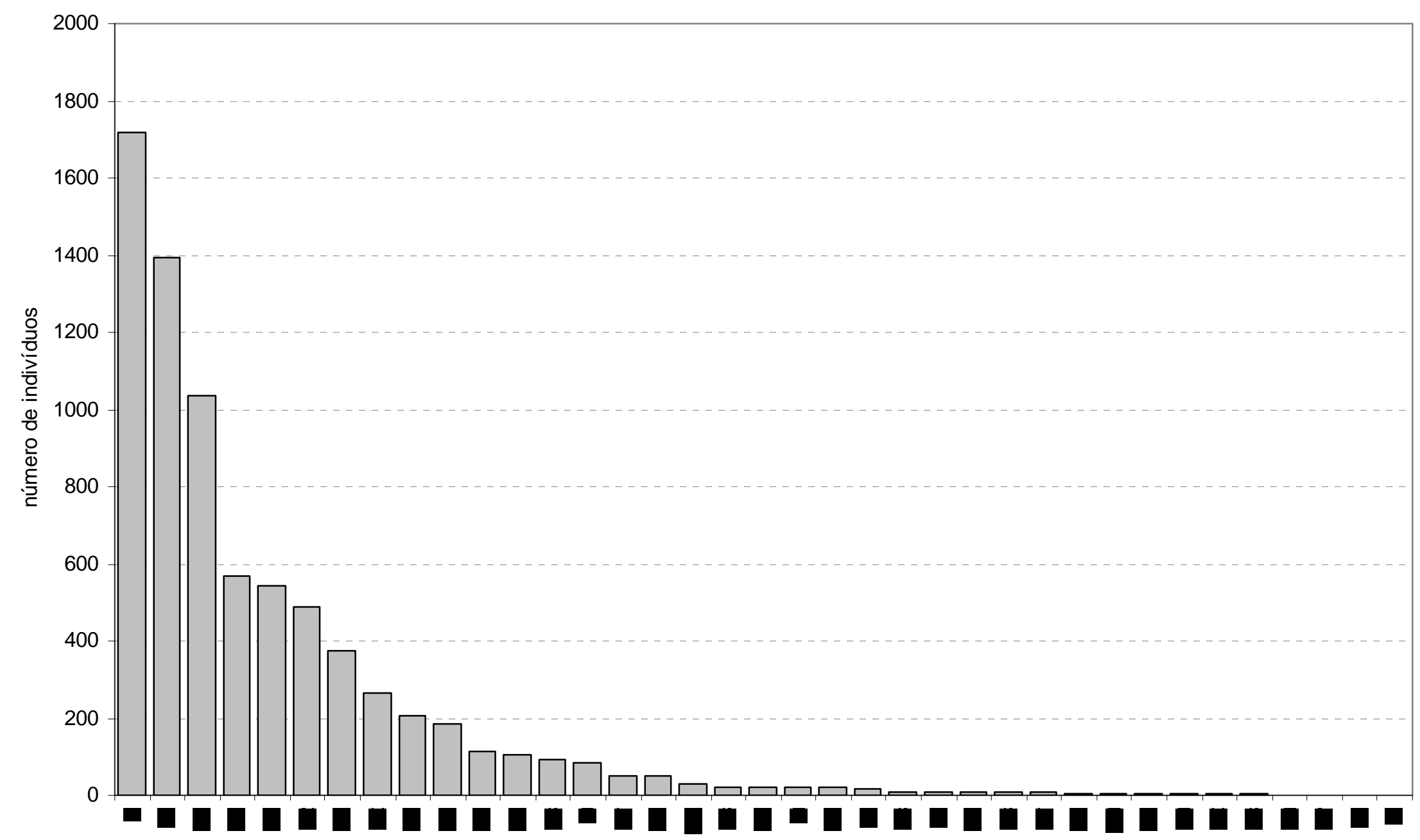

Figura 33 - Ranqueamento (ordenação) de espécies por importância em número de indivíduos de 22 amostras de peixes de riachos em microbacias de predomínio de matas nativas, na Bacia do Rio Corumbataí, SP 


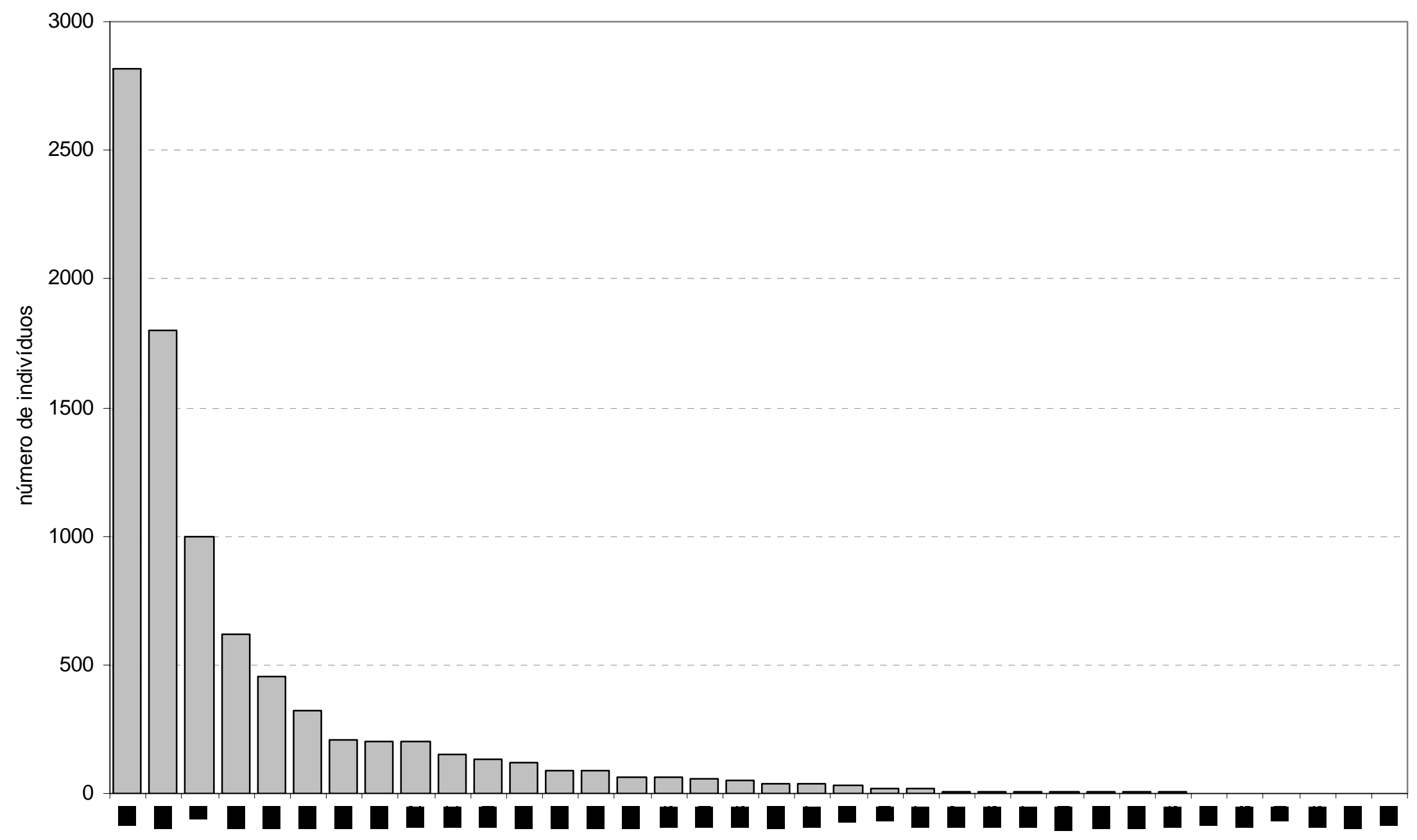

Figura 34 - Ranqueamento (ordenação) de espécies por importância em número de indivíduos de 27 amostras de peixes de riachos em microbacias ripárias, na Bacia do Rio Corumbataí, SP 
Tabela 33. Ranqueamento das dez espécies mais importantes por conjunto de amostras de peixes de riachos de microbacias de predomínio de pastagens, canaviais, matas nativas e ripárias. Amostras obtidas da Bacia do Rio Corumbataí, SP

\begin{tabular}{|c|c|c|c|c|}
\hline Posição & Canaviais & Pastagens & Matas nativas & Ripárias \\
\hline 1 & $\begin{array}{l}\text { Imparfinis } \\
\text { schubarti }\end{array}$ & $\begin{array}{l}\text { Serrapinnus } \\
\text { heterodon }\end{array}$ & $\begin{array}{l}\text { Imparfinis } \\
\text { schubarti }\end{array}$ & $\begin{array}{l}\text { Trichomycterus } \\
\text { sp. }\end{array}$ \\
\hline 2 & $\begin{array}{l}\text { Phalloceros } \\
\text { caudimaculatus }\end{array}$ & $\begin{array}{l}\text { Astyanax } \\
\text { altiparanae }\end{array}$ & $\begin{array}{l}\text { Trichomycterus } \\
\text { sp. }\end{array}$ & $\begin{array}{l}\text { Corumbataia } \\
\text { cuestae }\end{array}$ \\
\hline 3 & $\begin{array}{l}\text { Trichomycterus } \\
\text { sp. }\end{array}$ & $\begin{array}{l}\text { Astyanax } \\
\text { fasciatus }\end{array}$ & $\begin{array}{l}\text { Corumbataia } \\
\text { cuestae }\end{array}$ & $\begin{array}{l}\text { Imparfinis } \\
\text { schubarti }\end{array}$ \\
\hline 4 & $\begin{array}{l}\text { Astyanax } \\
\text { altiparanae }\end{array}$ & $\begin{array}{l}\text { Trichomycterus } \\
\text { sp. }\end{array}$ & $\begin{array}{l}\text { Astyanax } \\
\text { altiparanae }\end{array}$ & $\begin{array}{l}\text { Astyanax } \\
\text { paranae }\end{array}$ \\
\hline 5 & $\begin{array}{l}\text { Corumbataia } \\
\text { cuestae }\end{array}$ & $\begin{array}{l}\text { Poecilia } \\
\text { reticulata }\end{array}$ & $\begin{array}{l}\text { Phalloceros } \\
\text { caudimaculatus }\end{array}$ & $\begin{array}{l}\text { Poecilia } \\
\text { reticulata }\end{array}$ \\
\hline 6 & $\begin{array}{l}\text { Astyanax } \\
\text { paranae }\end{array}$ & $\begin{array}{l}\text { Corumbataia } \\
\text { cuestae }\end{array}$ & $\begin{array}{l}\text { Characidium } \\
\text { zebra }\end{array}$ & $\begin{array}{l}\text { Phalloceros } \\
\text { caudimaculatus }\end{array}$ \\
\hline 7 & $\begin{array}{l}\text { Poecilia } \\
\text { reticulata }\end{array}$ & $\begin{array}{l}\text { Imparfinis } \\
\text { schubarti }\end{array}$ & $\begin{array}{l}\text { Astyanax } \\
\text { paranae }\end{array}$ & $\begin{array}{l}\text { Astyanax } \\
\text { altiparanae }\end{array}$ \\
\hline 8 & $\begin{array}{l}\text { Hypostomus } \\
\text { ancistroides }\end{array}$ & $\begin{array}{l}\text { Geophagus } \\
\text { brasiliensis }\end{array}$ & $\begin{array}{l}\text { Astyanax } \\
\text { eigenmanniorum }\end{array}$ & $\begin{array}{l}\text { Hypostomus } \\
\text { ancistroides }\end{array}$ \\
\hline 9 & $\begin{array}{l}\text { Bryconamericus } \\
\text { sp. } 1\end{array}$ & $\begin{array}{l}\text { Astyanax } \\
\text { eigenmanniorum }\end{array}$ & $\begin{array}{l}\text { Bryconamericus } \\
\text { sp. } 1\end{array}$ & $\begin{array}{l}\text { Characidium } \\
\text { zebra }\end{array}$ \\
\hline 10 & $\begin{array}{l}\text { Geophagus } \\
\text { brasiliensis }\end{array}$ & $\begin{array}{l}\text { Astyanax } \\
\text { paranae }\end{array}$ & $\begin{array}{l}\text { Hypostomus } \\
\text { ancistroides }\end{array}$ & $\begin{array}{l}\text { Astyanax } \\
\text { eigenmanniorum }\end{array}$ \\
\hline
\end{tabular}

Tabela 34. Coeficientes de inclinação das retas (b) obtidas pela transformação logarítmica das curvas de ordenação por abundância de espécies, mostradas nas Figuras 31 a 34

\begin{tabular}{lc}
\hline Cobertura dominante & $b$ \\
\hline canaviais & -0.069 \\
pastagens & -0.059 \\
matas nativas & -0.073 \\
ripárias & -0.084 \\
\hline
\end{tabular}


A Figura 35 traz o resultado da análise de correspondência considerando todas as amostras pelas categorias estudadas. Nota-se, no primeiro componente, que as microbacias de pastagem estão fortemente segregadas das demais, enquanto que, pelo segundo componente, verifica-se separação entre as demais categorias. Esta análise visual reforça as Figuras 31 a 34 e a Tabela 28.

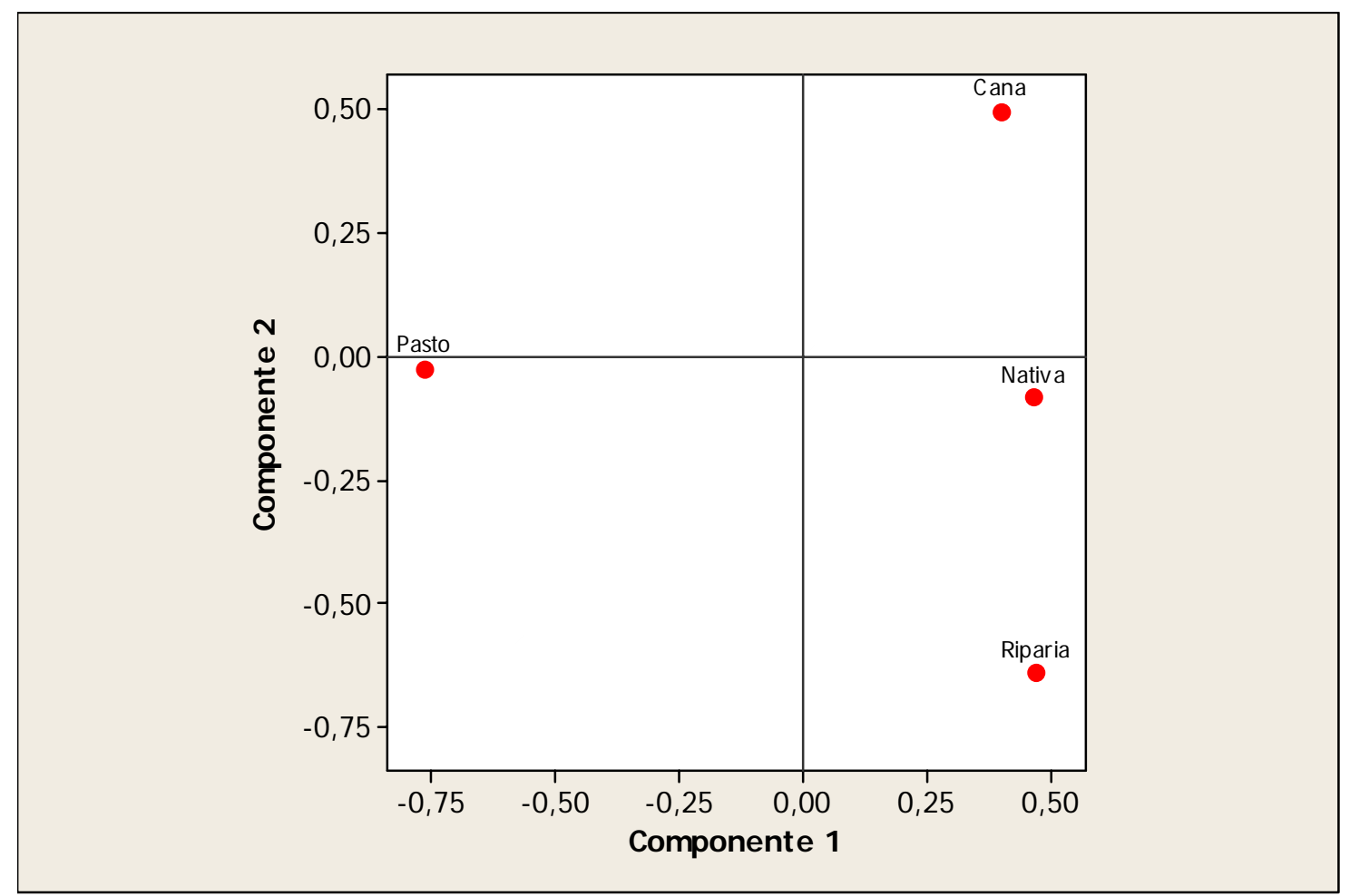

Figura 35 - Gráfico de análise de correspondência dos grupos de microbacias "pasto", "cana", "nativa" e "ripária", constituídos a partir das listas de abundâncias de 118 amostras de peixes de riachos amostrados entre 2003 e 2004 na Bacia do Rio Corumbataí, SP

\section{Uso e cobertura do solo e grupos tróficos}

O item 4.3.1 e 4.3.2 ilustrou que há interações significativas entre o número de grupos tróficos e a cobertura dominante na microbacia, e também, igualmente, em relação ao tipo de uso e cobertura da APP. As Figuras 36 e 37 ilustram como estão distribuídos os diferentes grupos tróficos em relação a estes grupos de microbacias. 
Quanto às quatro categorias destacadas neste estudo (microbacias de canaviais, pastagens, matas nativas e ripárias), parece haver grande diferenciação no número de indivíduos pertencentes ao grupo dos detritívoro-algívoros, bentófagos, onívoros e insetívoro (Figura 36). As diferenças são maiores entre as microbacias de pastagens e canaviais contra as microbacias de matas nativas e ripárias. Ocorre, por exemplo, maior quantidade de insetívoros e menor quantidade de onívoros nas microbacias onde há mais florestas.

Em relação à composição trófica em função do tipo de cobertura do solo na APP (Figura 37), notam-se padrões claros: o número de detritívoro-algívoros e insetívoros aumenta e o de onívoros decresce quando se consideram microbacias onde há canaviais, pastagens e matas nativas nas áreas de preservação permanente, respectivamente. Vale retomar que as microbacias com predomínio de canaviais na APP são apenas três. 

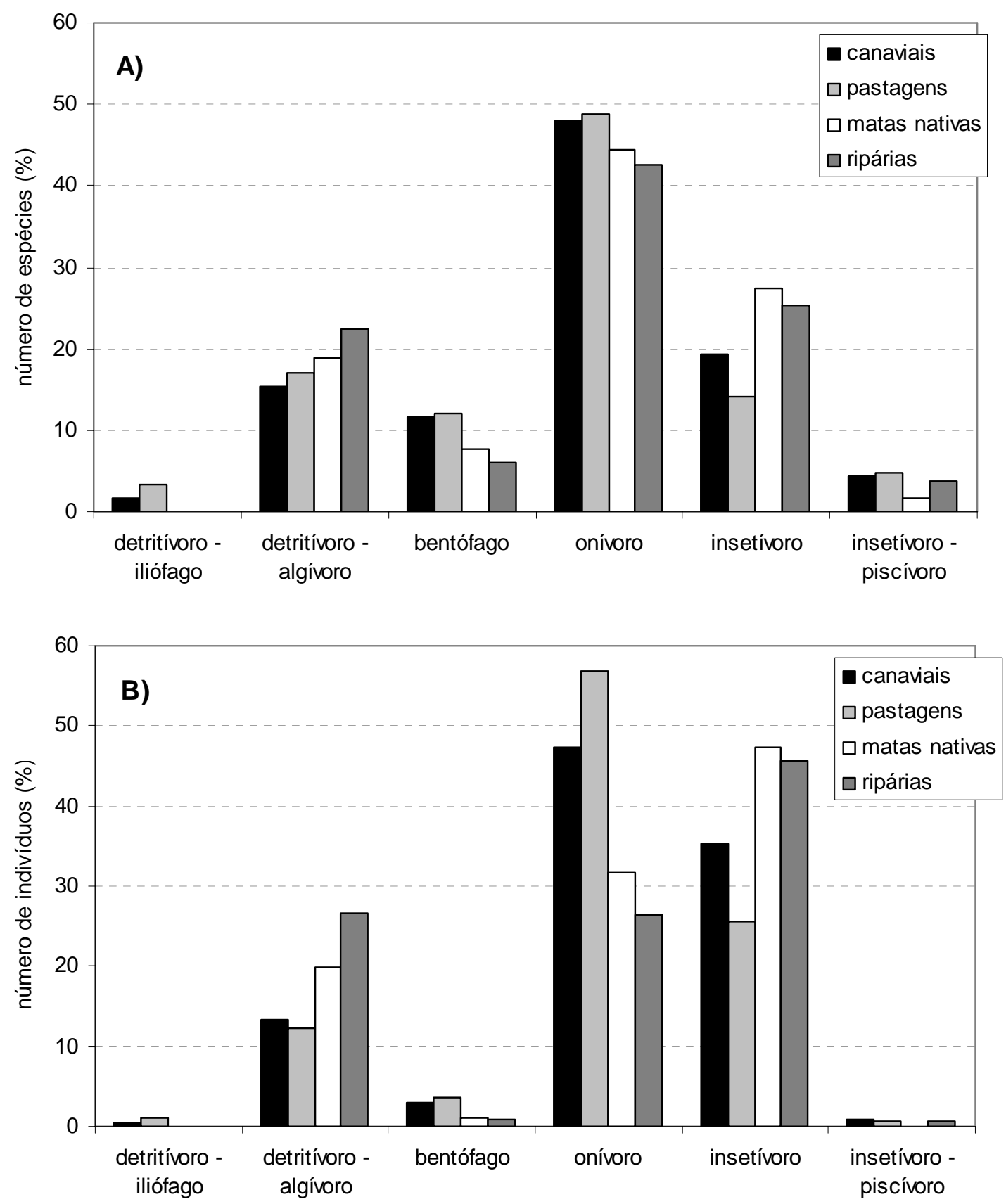

Figura 36 - Distribuição de freqüências percentuais de espécies (A) e indivíduos (B) por grupos tróficos em diferentes categorias de microbacias, separadas pelo predomínio do uso e uso e cobertura do solo na área total (canaviais e matas nativas) ou em sua APP ao longo da rede de drenagem (pastagens e ripárias). Total de 118 amostras 

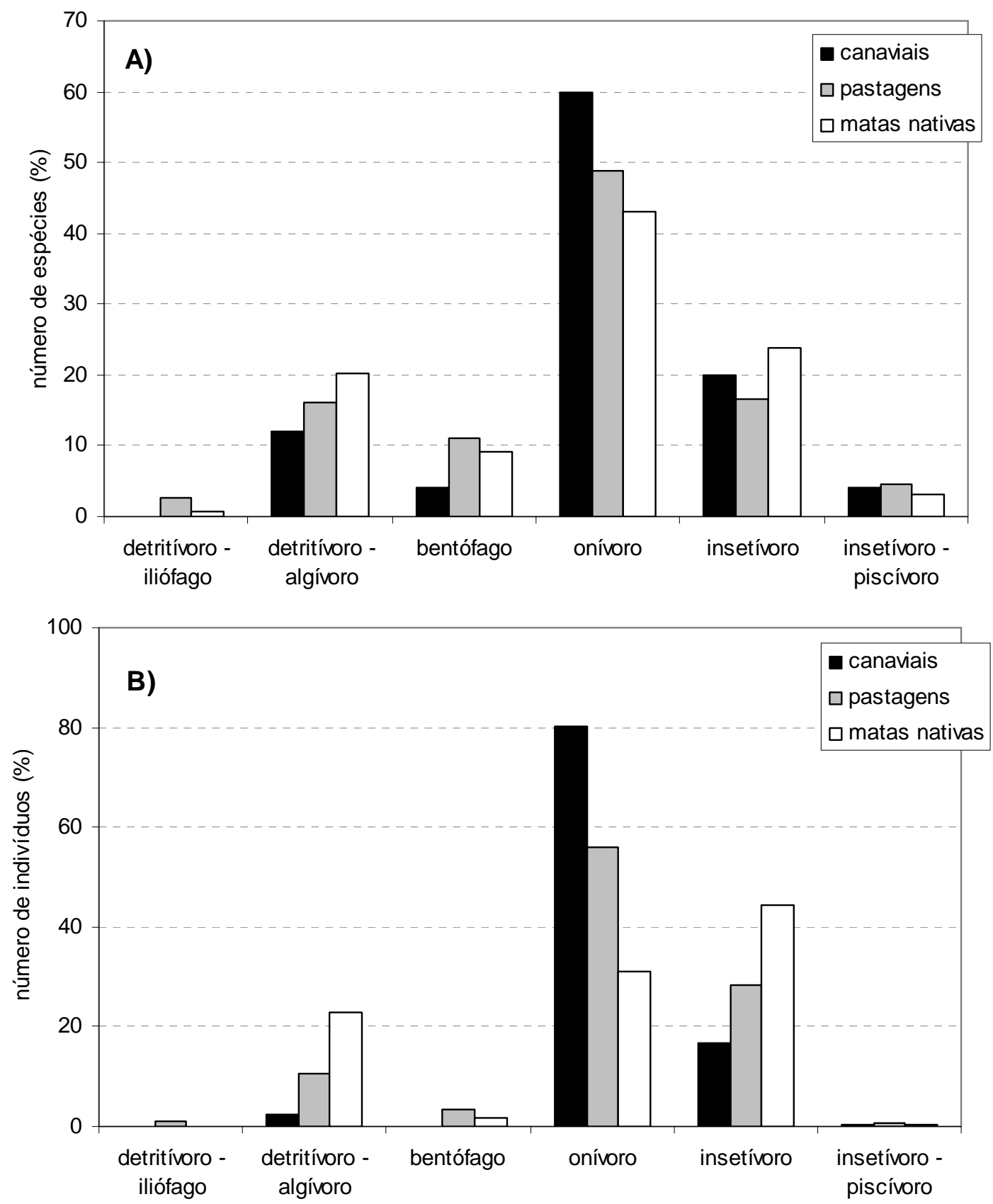

Figura 37 - Distribuição de freqüências percentuais de espécies (A) e indivíduos (B) por grupos tróficos em diferentes categorias de microbacias, separadas por critérios de uso e cobertura do solo em sua APP ao longo da rede de drenagem (variável DB). Total de 118 amostras 
Uso e cobertura do solo e a estrutura das comunidades

O cruzamento dos agrupamentos obtidos na análise conduzida no item 4.2.2 e o predomínio de uso e cobertura do solo também trazem resultados interessantes, uma vez que estes agrupamentos foram definidos com base na constituição específica de cada uma das amostras de peixes obtidas. As Tabelas 35 e 36 ilustram estas relações. As associações foram testadas por Qui-quadrado, admitindo a hipótese nula de freqüências esperadas iguais entre todas as categorias. Os valores resultantes de $p$ foram indicados nas Tabelas 35 e 36 . Ocorrem na Tabela 35 diversos valores de $p$ marginais e, na Tabela 36, um valor significante. Uma análise rápida destas tabelas indica que os padrões detectados não estão associados ao acaso com as categorias de uso e cobertura do solo. As comunidades do grupo I, por exemplo, parecem estar mais associadas às microbacias ripárias, por exemplo, embora o teste não apresente valor significativo de $p$.

Tabela 35. Número absoluto e porcentagem (entre parênteses) de amostras dos agrupamentos definidos na Figura 23 por classes de uso e cobertura do solo em microbacias da Bacia do Rio Corumbataí, SP

\begin{tabular}{lcccccc}
\hline Grupos & Canaviais & Pastagens & $\begin{array}{c}\text { Matas } \\
\text { nativas }\end{array}$ & Ripárias & Total & $p$ \\
\hline I & $2(9)$ & $5(24)$ & $4(19)$ & $\mathbf{1 0}(\mathbf{4 8 )}$ & 21 & 0,09 \\
II & $\mathbf{7 ( 3 7 )}$ & $\mathbf{8 ( 4 3 )}$ & $2(10)$ & $2(10)$ & 19 & 0,09 \\
III & $\mathbf{5 ( 5 0 )}$ & $0(0)$ & $\mathbf{4 ( 4 0 )}$ & $1(10)$ & 10 & 0,08 \\
IV & $\mathbf{5 ( 5 0 )}$ & $\mathbf{3 ( 3 0 )}$ & $1(10)$ & $1(10)$ & 10 & 0,22 \\
\hline
\end{tabular}

Os dados referem-se a 60 amostras obtidas nas estações chuvosas de 2003 e 2004. Em negrito: valores maiores que $30 \%$. Valores de $p$ relativos à análise de Qui-quadrado 
Tabela 36. Número absoluto e porcentagem (entre parênteses) de amostras dos agrupamentos definidos na Figura 24 por classes de uso e cobertura do solo em microbacias da Bacia do Rio Corumbataí, SP

\begin{tabular}{lcccccc}
\hline Grupos & Canaviais & Pastagens & Matas nativas & Ripárias & Total & $p$ \\
\hline I & $4(20)$ & $4(20)$ & $4(20)$ & $\mathbf{8}(\mathbf{4 0 )}$ & 20 & 0,49 \\
II* & $\mathbf{7 ( 7 0 )}$ & $0(0)$ & $\mathbf{3 ( 3 0 )}$ & $0(0)$ & 10 & $<0,00$ \\
III & $2(25)$ & $\mathbf{4 ( 5 0 )}$ & $1(13)$ & $1(13)$ & 8 & 0,39 \\
IV & $1(13)$ & $\mathbf{5 ( 6 3 )}$ & $1(13)$ & $1(13)$ & 8 & 0,11 \\
V & $\mathbf{5 ( 4 2 )}$ & $2(17)$ & $2(17)$ & $3(25)$ & 12 & 0,57 \\
\hline
\end{tabular}

Os dados referem-se a 60 amostras obtidas nas estações secas de 2003 e 2004. Em negrito: valores maiores que $30 \%$. Valores de $p$ relativos à análise de Qui-quadrado. Grupo marcado com *: freqüências significativamente distintas da distribuição uniforme, com $\alpha=0,05$

\subsubsection{Abundância e diversidade de comunidades e características do habitat}

Correlações com variáveis ambientais: abordagem univariada

Análises de correlação simples ( $r$ de Pearson) foram realizadas entre as diversas variáveis de habitat (contínuas e ordinais) e as variáveis-resposta $N, H^{\prime}$ e GT. Os resultados foram colocados no Anexo $\mathrm{H}$. Quanto às variáveis nominais descritivas (e a variável LP, ordinal), foram realizadas análises de variância, dispostas no Anexo I. As análises foram conduzidas sobre os conjuntos de amostras tomados nas estações secas e chuvosas.

Em todos os conjuntos de variáveis propostos no item 3.5.3 foram encontradas correlações significativas. Isto indica que, ao menos parte da variação de $N, H^{\prime}$ e $G T$ está correlacionado com fatores tão diversos quanto a posição relativa do ponto de amostragem, relevo da microbacia, do entorno do canal e da própria estrutura do canal (escala microgeográfica), química da água e uso e cobertura do solo (Tabela 37). Quanto às variáveis nominais, foram encontradas outras interações entre as variáveis descritivas e resposta (Tabela 37). Entretanto, como as microbacias não foram selecionadas para 
estas comparações, as análises são bastante desbalanceadas. Os resultados, portanto, devem ser vistos apenas como exploratórios.

Tabela 37. Lista de variáveis descritivas de habitat que apresentaram correlações $(r$ de Pearson) ou cuja análise de variância (ANOVA tipo I) categorizada pela variável (em itálico) foi significativa $(\alpha=0,05)$. Abreviações das variáveis descritivas como nas Tabelas 10, 11 e 15. Detalhes nos Anexos H e I

\begin{tabular}{|c|c|c|c|c|}
\hline & Categoria da variável & $N$ & $H^{\prime}$ & $G T$ \\
\hline \multirow{7}{*}{ 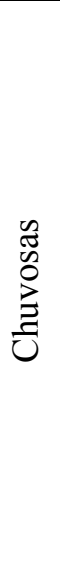 } & Posição e contexto da microbacia & - & HS, SH, DE & $\mathrm{DE}$ \\
\hline & Métrica de microbacia & - & $\mathrm{EL}, \mathrm{CI}$ & EL, EM, DG \\
\hline & Uso e cobertura do solo & UA & UP & $\begin{array}{l}\text { CP, UP, UM, AJ, } \\
\text { AM }\end{array}$ \\
\hline & Geologia e pedologia & - & $E R$ & - \\
\hline & Parâmetros físicos e químicos & & $\mathrm{NN}, \mathrm{KA}, \mathrm{OD}, \mathrm{TG}$ & $\mathrm{KA}, \mathrm{CO}, \mathrm{OD}, \mathrm{SA}$ \\
\hline & Métrica do segmento & - & $\mathrm{AB}, \mathrm{LP}, \mathrm{AP}, \mathrm{SO}$ & $\mathrm{AB}, \mathrm{LP}, \mathrm{CV}, \mathrm{SO}$ \\
\hline & Métrica do canal & $\mathrm{RP}, \mathrm{PM}, \mathrm{VC}, \mathrm{PA}$ & $\begin{array}{l}\text { PC, RP, PM, PX, } \\
\text { VP, VC, OV, MV, } \\
\text { VV }\end{array}$ & $\begin{array}{l}\text { RP, PF, PM, PX, } \\
\text { VP, VC, MV }\end{array}$ \\
\hline \multirow{7}{*}{$\begin{array}{l}\mathscr{\Xi} \\
\tilde{ల} \\
\tilde{\omega}\end{array}$} & Posição e contexto da microbacia & - & HS & $\mathrm{DE}$ \\
\hline & Métrica de microbacia & - & $\mathrm{CI}$ & - \\
\hline & Uso e cobertura do solo & - & - & $\mathrm{CP}, \mathrm{UM}, \mathrm{AJ}$ \\
\hline & Geologia e pedologia & - & $E R, T S$ & - \\
\hline & Parâmetros físicos e químicos & - & SA, TG & $\mathrm{AZ}, \mathrm{TU}$ \\
\hline & Métrica do segmento & & $\mathrm{CV}, \mathrm{AP}, \mathrm{SO}$ & $\mathrm{CV}, \mathrm{AP}, \mathrm{SO}$ \\
\hline & Métrica do canal & MS & $\begin{array}{l}\text { VE, VP, LM, PX, } \\
\text { AC, PA }\end{array}$ & $\begin{array}{l}\text { VE, QT, PX, VP, } \\
\text { VC, PA, PU, OV }\end{array}$ \\
\hline
\end{tabular}

$N$ = número de indivíduos, $H^{\prime}=$ índice de diversidade de Shannon e $G T=$ número de grupos tróficos. Número de amostras: de 60 e 58 riachos, tomadas nas estações chuvosas e secas de 2003 e 2004, respectivamente

Diversidade de peixes e variáveis ambientais: abordagem multivariada 
Nas Tabelas 38, 39 e 40, a seguir, são apresentados os resumos das estatísticas do modelo de regressão múltipla para as amostras da estação chuvosa. Das 69 variáveis descritivas (contínuas e ordinais) mensuradas para cada microbacia, foram testadas 24 das mais correlacionadas (com coeficiente de correlação $r$ de Pearson $>0,3$ ) ao índice de diversidade de Shannon $\left(H^{\prime}\right)$. Após o processo de otimização do modelo, oito variáveis foram qualificadas como altamente significativas. São elas: DE (diferença de elevação entre o ponto de coleta e um tributário de quarta ordem à jusante); CI (circularidade da microbacia); NN (concentração de nitrogênio amoniacal); KA (concentração de potássio), PC (relação entre unidades de poços e corredeiras e run); RP (relação entre áreas de poços e corredeiras e run); PM (profundidade média); e LP (largura média da planície de inundação). As variáveis $\mathrm{DE}, \mathrm{CI}$ e RP são relacionadas inversamente ao índice $H^{\prime}$. As oito variáveis não são correlacionadas entre si.

A Tabela 38 indica que o modelo explica cerca de $49 \%$ da variação de $H^{\prime}$ em função das oito variáveis destacadas. Trata-se de um valor relativamente alto, dada a enorme complexidade de fatores que podem atuar na determinação da diversidade local, afora a própria sazonalidade (a amostra é composta de duas estações chuvosas). O modelo é altamente significativo, com um valor de $p$ para $R_{a j}^{2}$ virtualmente igual a zero (Tabela 39).

Tabela 38. Resumo do modelo de regressão múltipla sobre a variável $H^{\prime}$, considerando como preditores uma constante e oito, a partir de 60 amostras de peixes de riachos da Bacia do Rio Corumbataí, tomadas nas estações chuvosas de 2003 e 2004

\begin{tabular}{ccccc}
\hline Modelo: Chuva & $R$ & $R^{2}$ & $R_{a j}^{2}$ & $\begin{array}{c}\text { Erro padrão da } \\
\text { estimativa }\end{array}$ \\
\hline- & 0,7500 & 0,5620 & 0,4930 & 0,3855 \\
\hline
\end{tabular}

Variáveis descritivas: DE, CI, KA, NN, PC, RP, PM e LP 
Tabela 39. Resultados da Análise de Variância (ANOVA) sobre o modelo de regressão resumido na Tabela 38

\begin{tabular}{lccccc}
\hline Modelo: Chuva & $\begin{array}{c}\text { Soma de } \\
\text { quadrados }\end{array}$ & $\begin{array}{c}\text { Graus de } \\
\text { liberdade }\end{array}$ & $\begin{array}{c}\text { Quadrados } \\
\text { médios }\end{array}$ & $F$ & $p$ \\
\hline Regressão & 9,725 & 8 & 1,216 & 8,182 & 0,000 \\
Resíduo & 7,577 & 51 & 0,149 & & \\
Total & 17,303 & 59 & & & \\
\hline
\end{tabular}

Tabela 40. Valores dos coeficientes do modelo de regressão descrito na Tabela 38, não-estandardizados, estandardizados $(\Omega)$ e respectivos valores de $t$ e sua probabilidade associada

\begin{tabular}{lccccc}
\hline $\begin{array}{l}\text { Modelo: } \\
\text { chuva }\end{array}$ & Coeficientes não estandardizados & $\begin{array}{c}\text { Coeficientes } \\
\text { estandardizados }\end{array}$ & & \\
& $b$ & erro- padrão & $\beta$ & $t$ & $p$ \\
\hline Constante & 1,100 & 0,296 & & 3,717 & 0,001 \\
DE & $-0,006$ & 0,002 & $-0,317$ & $-3,010$ & 0,040 \\
CI & $-0,642$ & 0,389 & $-0,177$ & $-1,754$ & 0,085 \\
NN & 0,642 & 0,238 & 0,299 & 2,694 & 0,010 \\
KA & 0,009 & 0,051 & 0,163 & 1,540 & 0,130 \\
PC & 0,680 & 0,266 & 0,280 & 2,555 & 0,014 \\
RP & $-0,398$ & 0,211 & $-0,269$ & $-1,886$ & 0,065 \\
PM & 0,007 & 0,006 & 0,346 & 2,920 & 0,005 \\
LP & 0,135 & 0,074 & 0,191 & 1,826 & 0,074 \\
\hline
\end{tabular}

A Tabela 40 indica que há diversas variáveis influenciando a determinação de $H^{\prime}$, considerados os valores de $\beta$. O modelo parece ser relativamente menos inflacionado 
ou deflacionado pelas variáveis CI, KA e LP. Nota-se, também que variáveis oriundas de diversos níveis de organização estão presentes no modelo, desde variáveis de forma e métrica das microbacia (DE, CI), química da água (NN, KA), métricas do canal (PC, RP, PM) e métricas do segmento de amostragem (LP).

O modelo de regressão múltipla do conjunto de amostras obtidas na seca tem seu resumo, análise de variância e valores de coeficientes dispostos nas Tabelas 41, 42 e 43. Foi testado um número igual de variáveis que para o modelo da estação chuvosa, mas apenas três variáveis contribuíram para o modelo: CI (circularidade da microbacia), SO (sombreamento do canal) e VP (variância da profundidade do canal), sendo que as duas primeiras variáveis influenciam negativamente o índice de diversidade $H^{\prime}$. As variáveis não são correlacionadas entre si.

Este modelo, entretanto, explica cerca de $35 \%$ da variação das três variáveis se mostra altamente significativo para este valor. Ainda se trata de um valor alto quando se considera que cerca de 70 variáveis foram testadas (individualmente) quanto à sua correlação com o índice de diversidade.

Tabela 41. Resumo do modelo de regressão múltipla sobre a variável H’, considerando como preditores uma constante as variáveis descritivas CI, SO e VP, a partir de 58 amostras de peixes de riachos da Bacia do Rio Corumbataí, tomadas nas estiagens de 2003 e 2004

\begin{tabular}{ccccc}
\hline Modelo: Seca & $R$ & $R^{2}$ & $R_{a j}^{2}$ & $\begin{array}{c}\text { Erro padrão da } \\
\text { estimativa }\end{array}$ \\
\hline- & 0,621 & 0,386 & 0,352 & 0,431 \\
\hline
\end{tabular}


Tabela 42. Resultados da Análise de Variância (ANOVA) sobre o modelo de regressão resumido na Tabela 41

\begin{tabular}{lccccc}
\hline Modelo: Seca & $\begin{array}{c}\text { Soma de } \\
\text { quadrados }\end{array}$ & $\begin{array}{c}\text { Graus de } \\
\text { liberdade }\end{array}$ & $\begin{array}{c}\text { Quadrados } \\
\text { médios }\end{array}$ & $F$ & $p$ \\
\hline Regressão & 6,306 & 3 & 2,102 & 11,317 & 0,000 \\
Resíduo & 10,029 & 54 & 0,186 & & \\
Total & 16,335 & 57 & & & \\
\hline
\end{tabular}

Tabela 43. Valores dos coeficientes do modelo de regressão descrito na Tabela 41, não-estandardizados, estandardizados $(ß)$ e respectivos valores de $t$ e sua probabilidade associada

\begin{tabular}{lccccc}
\hline $\begin{array}{l}\text { Modelo: } \\
\text { Seca }\end{array}$ & Coeficientes não estandardizados & $\begin{array}{c}\text { Coeficientes } \\
\text { estandardizados }\end{array}$ & & \\
& $b$ & erro- padrão & $\beta$ & $t$ & $p$ \\
\hline Constante & 1,882 & 0,266 & & 7,072 & 0,000 \\
CI & $-0,765$ & 0,440 & $-0,198$ & $-1,736$ & 0,088 \\
SO & $-0,007$ & 0,003 & $-0,299$ & $-2,406$ & 0,020 \\
VP & 0,005 & 0,002 & 0,309 & 2,500 & 0,015 \\
\hline
\end{tabular}

Comparando os valores dos coeficientes estandardizados da Tabela 43, observase, respectivamente, maior peso da variável SO e VP, negativa e positivamente. Ambas as variáveis não aparecem como bons descritores para a diversidade na época da chuva.

\subsubsection{Similaridade das comunidades e características do habitat}

Os agrupamentos obtidos nas análises do item 4.2.2 foram comparados às diversas variáveis ambientais mensuradas neste estudo, de modo análogo ao citado no 
item 4.3.1. O objetivo neste ponto é o de formar um perfil dos agrupamentos, de onde se pode levantar hipóteses sobre os fatores influenciando a composição específica destes grupos. Os resultados das análises são extensos, e foram colocados no Anexo J. A Tabela 44 ilustra, resumidamente, as relações estatisticamente significativas entre os agrupamentos e variáveis ambientais.

Tabela 44. Resumo das variáveis descritivas do meio ambiente estatisticamente significativas (ANOVA tipo I, $\alpha=0,05$ ) em relação aos agrupamentos obtidos através da análise de cluster nas estações chuvosas e secas de 2003 e 2004 (Figuras 23 e 24). Detalhes no Anexo J

\begin{tabular}{lll}
\hline Categorias das variáveis & Chuvosas & Secas \\
\hline Posição e contexto da microbacia & HS & HS \\
Métrica de microbacia & EL, EM, DG, CI & EL, EM, DG, CI \\
Uso e cobertura do solo & $\begin{array}{l}\text { CP, DC, UC, UP, UM, } \\
\text { AJ, AM }\end{array}$ & UC, UP, UR, AJ, AM \\
Geológicas e pedológicas & - & - \\
Parâmetros físicos e químicos & AT, KA, CA, DU, CN & AZ, OD \\
Métricas de segmento & IS & SO \\
Métricas de canal & RP, PM, PX, VC, MV & VE, PX, VP, VC \\
\hline
\end{tabular}

A complexidade da estrutura das comunidades de peixes amostradas pode ser ordenadas em um espaço estatístico reduzido, ao mesmo tempo em que são delineadas correlações entre estas ordenações e as dimensões estatísticas criadas. Para tanto, foi utilizada a análise de escalonamento multidimensional não-métrico (NMDS).

O Anexo K mostra os gráficos de estresse (isto é, a "taxa de erro" global da ordenação) em função do número de dimensões da ordenação (scree-plots) dos dois conjuntos de amostras. A partir do exame destes gráficos, optou-se por trabalhar com apenas três dimensões como uma solução de compromisso entre a representação didática 
desta ordenação e sua validade estatística, conforme proposto por Kruskal \& Wish (1978).

As Figuras 38 a 43 apresentam os gráficos de ordenação das comunidades de peixes em função das três dimensões escolhidas para esta análise. Nos gráficos foram delineados também os agrupamentos obtidos nas análises ilustrada no item 4.2.2. Tratase de uma representação redundante que, no entanto, ilustra a convergência de padrões observados por meio de análises distintas. Além disto, nas figuras foram incluídas as correlações significativas entre as dimensões (um, dois e três) e variáveis ambientais contínuas. Foram citadas até cinco correlações positivas e cinco negativas para cada dimensão considerada. Estas variáveis foram escolhidas de um grupo maior (Anexo L), após a inspeção da matriz de correlação entre todas variáveis significativamente relacionadas às dimensões. Elas podem ser observadas ao longo dos eixos dos gráficos das Figuras 38-43. As figuras ilustram também, com setas, os pontos que não foram ordenados próximos aos agrupamento obtidos na análise de cluster. Apresentam-se, em média, sete destes pontos por cada figura.

Quanto à análise do grupo de amostras das estações chuvosas (Figuras 38-40), observa-se boa separação dos quatro agrupamentos considerados entre as dimensões 1 e 2 (Figura 38) e entre as dimensões 1 e 3 (Figura 39). A ordenação das amostras pelas dimensões 2 e 3 (Figura 40) não apresenta boa separação dos grupos. A análise mostra que os grupos, representando comunidades mais similares entre si podem ser diferenciadas pela dimensão 1 (grupos I e IV contra grupos II e III) e pelas dimensões 2 (grupos I e II contra grupos III e IV) e 3, parcialmente (grupos I, II e III contra grupo IV). Considerando as correlações associadas à dimensão 1, observa-se que, por exemplo, os grupos II e III ocorrem em áreas mais baixas e menos declivosas (variável EM e DG), com largura da planície de inundação maior (LP). Neste grupo há maiores teores de potássio na água (KA), que te, condutividade mais elevada $(\mathrm{CN})$. Os canais tem maior profundidade média (PM), maior área em poços (RP), menor velocidade média (VM), e são menos sombreados (SO). Ocorrem maior porcentagem de mata nas microbacias (UM) do que os grupos I e IV. A dimensão 2 indica que os grupos I e II ocorrem em rios em microbacias de menor porcentagem de canaviais (UC) e maior de pastagens (UP) em 
suas microbacias. A dimensão 3 correlaciona-se bem às microbacias de predomínio de pastagens (UP), além de separar canais de maior complexidade de padrões de fluxo (PU) com grande porcentagem de areia no leito (PA) e teor de oxigênio dissolvido (OD).

Deve-se ressaltar que, tal como nos resultados obtidos nas análise conduzidas no item 4.3.2, aparecem correlações entre as dimensões das ordenações e variáveis descritivas de habitas representando características muito distintas do meio ambiente, desde a conformação geomorfológica, uso e cobertura do solo, química da água e aspectos próprios da morfologia do canal. Aqui, entretanto, fica clara a importância do uso da terra em termo de porcentagens de pastagens, canaviais e pastagens. As correlações destas variáveis com as dimensões das Figuras 38, 39 e 40 foram destacadas. 


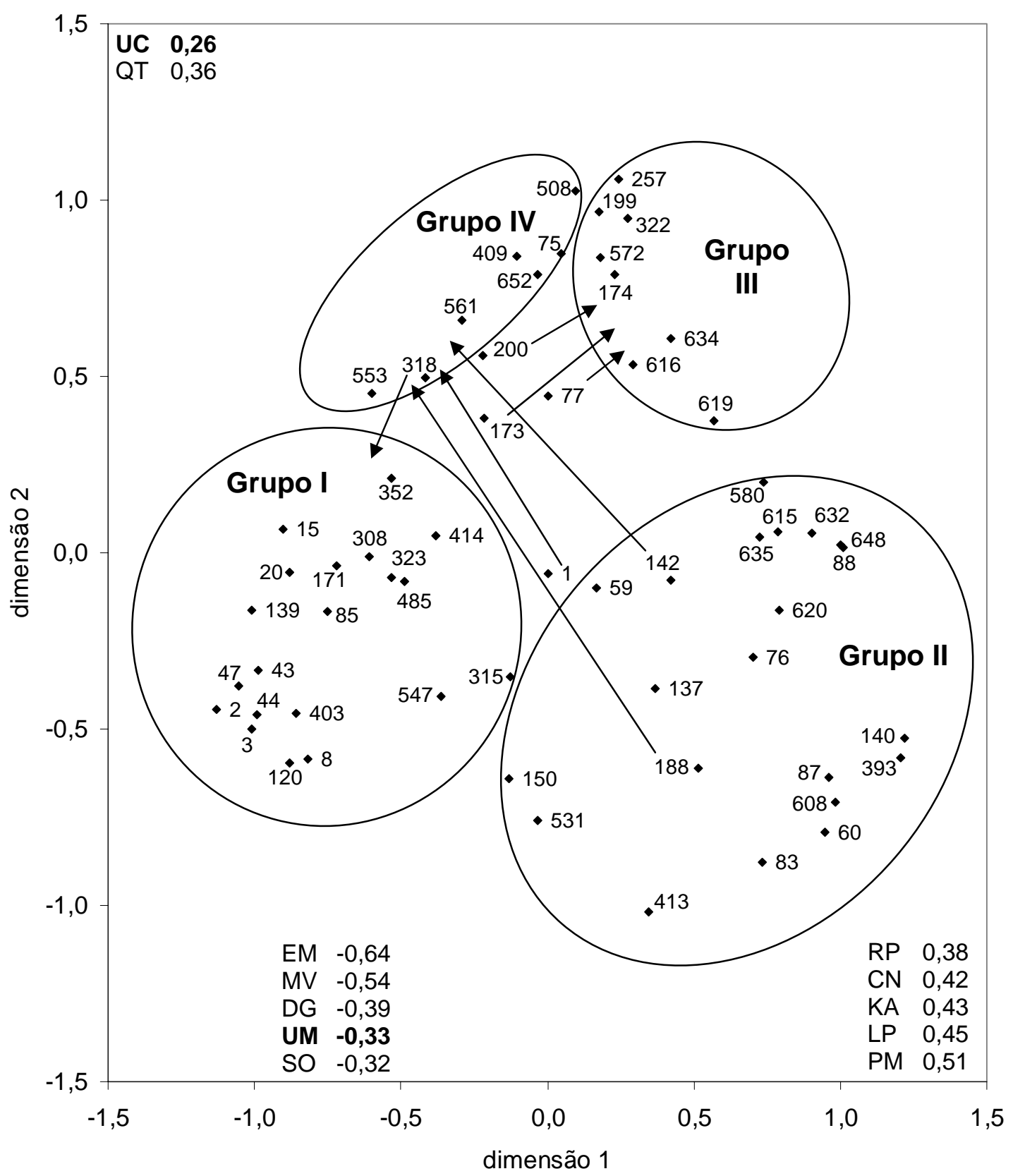

Figura 38 - Ordenação por escalonamento multidimensional não métrico (NMDS) de 60 amostras de peixes de riachos da Bacia do Rio Corumbataí, SP, obtidas nas estações chuvosas de 2003 e 2004. São ilustrados agrupamentos obtidos por análise de cluster (Figura 23) e correlações das dimensões com variáveis de habitat. Dimensão 1 × Dimensão 2 


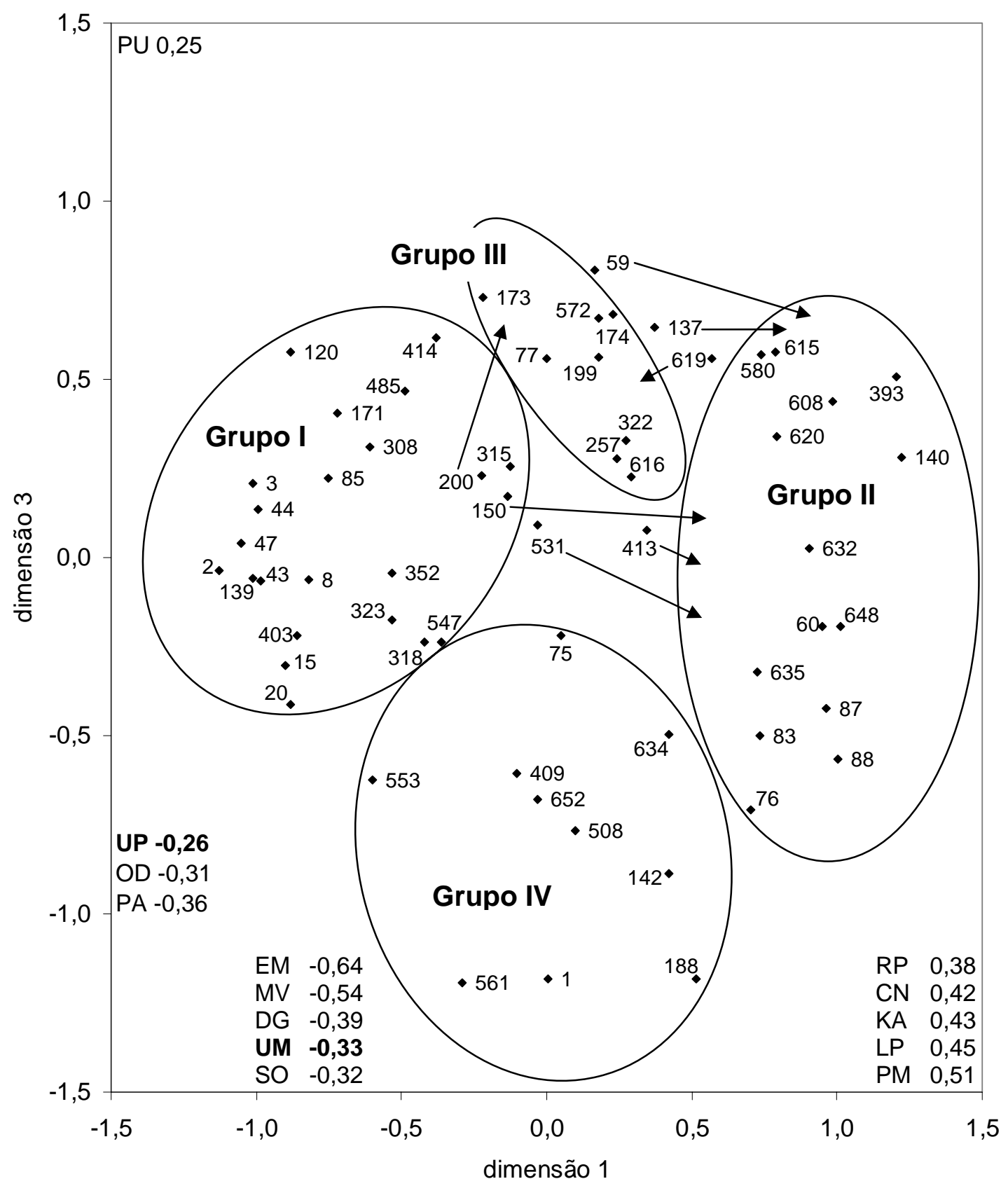

Figura 39 - Ordenação por escalonamento multidimensional não métrico (NMDS) de 60 amostras de peixes de riachos da Bacia do Rio Corumbataí, SP, obtidas nas estações chuvosas de 2003 e 2004. São ilustrados agrupamentos obtidos pela análise de agrupamento (Figura 23) e correlações das dimensões com variáveis de habitat. Dimensão 1 × Dimensão 3 


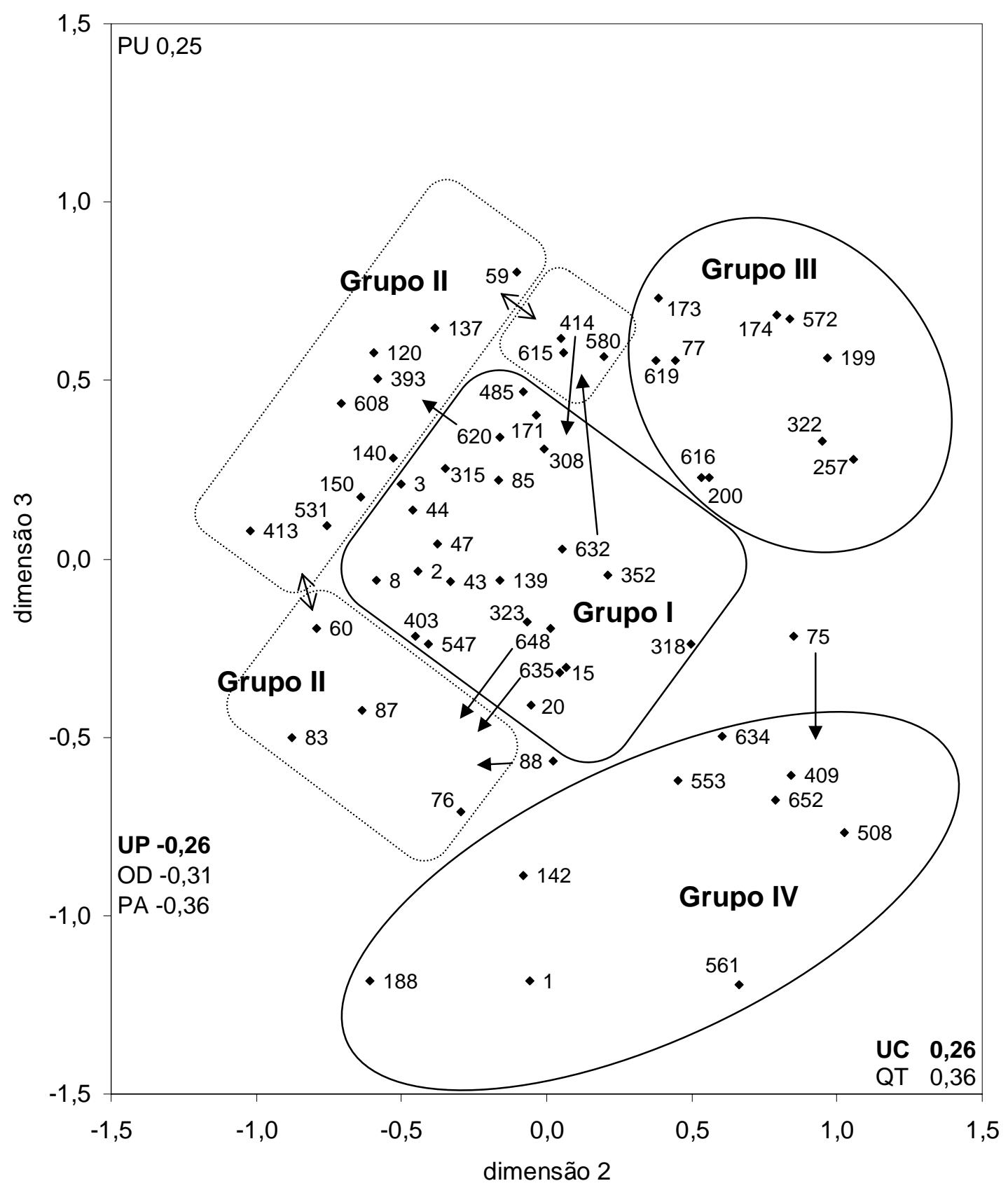

Figura 40 - Ordenação por escalonamento multidimensional não métrico (NMDS) de 60 amostras de peixes de riachos da Bacia do Rio Corumbataí, SP, obtidas nas estações chuvosas de 2003 e 2004. São ilustrados agrupamentos obtidos por análise de cluster (Figura 23) e correlações das dimensões com variáveis de habitat. Dimensão 2 × Dimensão 3 
Similar ao discutido sobre as Figuras 38-40, é possível observar separação dos cinco grupos obtidos pela análise do item 4.2.2 através as ordenações propostas nas Figuras 41 a 43, isto é, através das dimensões 1, 2 e 3, para as amostras de peixes nas estações de secas. A dimensão 1, por exemplo, separa parcialmente os grupos: I, II+V e III+IV. A dimensão 2 é efetiva em diferenciar dois grande blocos, entre os grupos III e V (e I, parcialmente) e os grupos II e IV. Já a dimensão 3 separa os blocos compostos pelos grupos I e IV (e III, parcialmente) dos grupos II e V.

A dimensão 1 mostra, similar aos resultados da análise para o conjunto de amostras das estações chuvosas, correlação das variáveis EM, indicando que nos grupos III e IV ocorrem amostras tomadas de áreas baixas, em oposição (especialmente) ao grupo I. Destaque-se a variável DE, indicando que os grupos à esquerda desta dimensão destacam-se (grupo I, especialmente) contém amostras de pontos amostrados muito elevados em relação a rios maiores. Também são apresentadas correlações desta dimensão com diversas variáveis descrevendo aspectos do canal (RP, PM, VP e MV), destacando que os grupos III e IV aparecem em canais com mais poços, mais profundos, de maior volume, e menor velocidade média. A dimensão indica também diferenciação nos teores de potássio (KA), magnésio $\mathrm{MG}$ ), oxigênio dissolvido (OD) na água dos canais ao longo deste eixo. Ocorrem, também, à esquerda desta dimensão, pontos coletados de sub-bacias de maior porcentagem de matas nativas. A dimensão 2 assemelha-se à mesma dimensão da análise anterior: as amostram aparecem separadas por sua porcentagem de canaviais (UC) e pastagens (UP) em microbacias, além do teor de potássio (KA) e oxigênio (OD). Deste modo, por exemplo, observa-se que esta ordenação separa as amostras obtidas em dimensões que se relacionam com características do uso, sendo os agrupamentos II e IV (e I, parcialmente) com maior porcentagem de canaviais e, indiretamente pela baixa porcentagem de pastagens, as de predomínio de matas nativas. A dimensão 3 indica por suas correlações que os grupos II, III e V apresentam-se com maior porcentagem de canaviais (UC) e menor de pastagens (UP) em suas microbacias, são bastante sombreados (SO) e com muitos troncos (QT). Também pode ser destacada a variável AM na dimensão 3, que somada à sua correlação com a dimensão 1, destaca comunidades de riachos das sub-bacias mais florestadas, na 
porção superior esquerda da Figura 42. A Figura 43, da mesma forma, soma duas dimensões correlacionadas à porcentagem de uso por pastagens e canaviais nas microbacias (destacadas nas Figuras 41, 42 e 43). Note-se que, aparte os grupos que se destacam pela quantidade de microbacias com predomínio de pastagens e canaviais, o grupo I, localizado na porção central desta ordenação apresenta bom número de microbacias de predomínio de matas nativas e "ripárias". A Figura 40 apresenta, da mesma forma, o grupo I localizado na porção central das ordenações pelas dimensões 2 e 3, que apresentam correlações com o uso por pastagens e canaviais em microbacias. Assim, a análise por NMDS é capaz de evidenciar padrões da relação entre a composição específica das amostras e as variáveis do uso e cobertura do solo. 


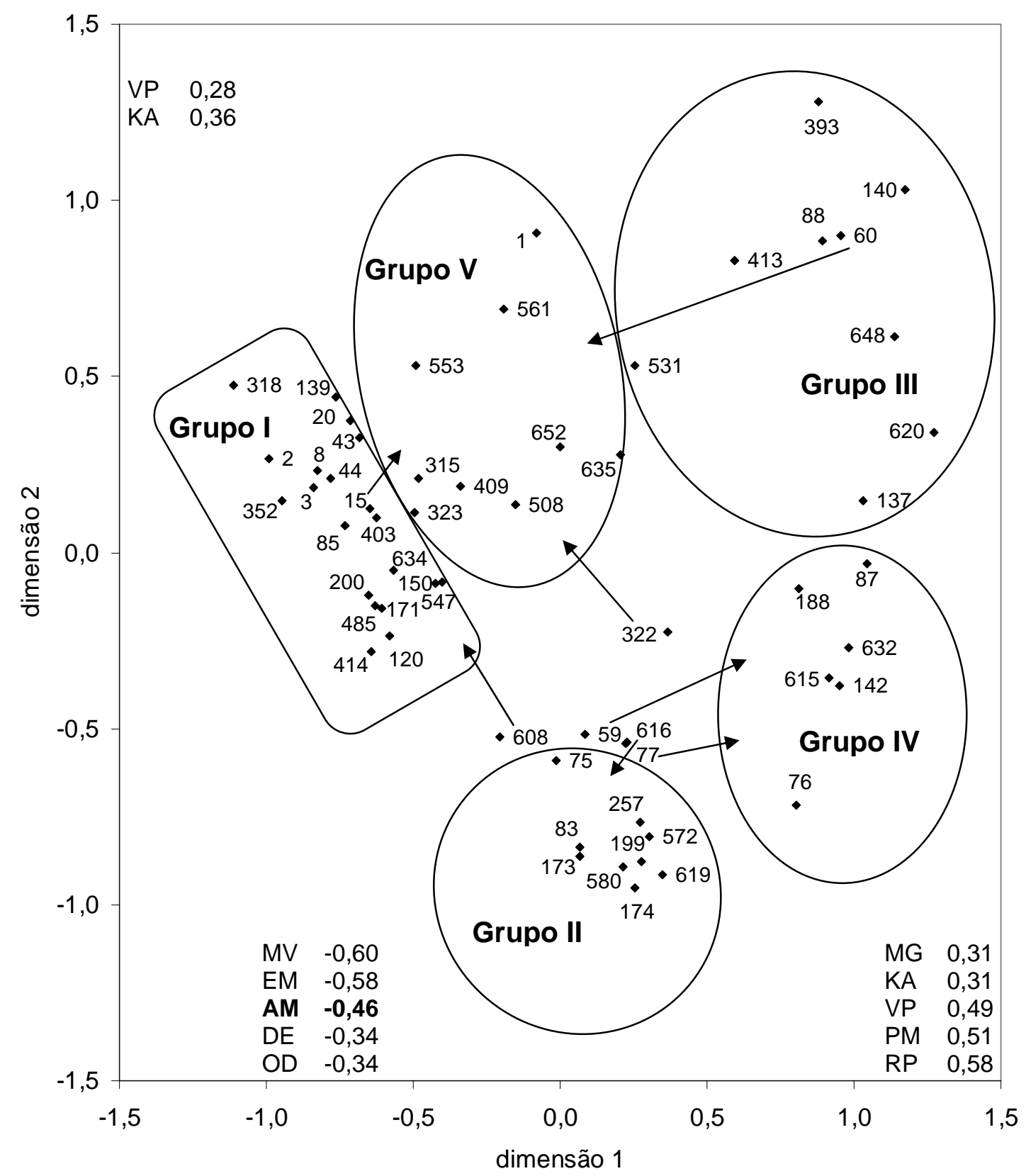

Figura 41 - Ordenação por escalonamento multidimensional não métrico (NMDS) de 58 amostras de peixes de riachos da Bacia do Rio Corumbataí, SP, obtidas nas estações secas de 2003 e 2004. São ilustrados agrupamentos obtidos por análise de cluster (Figura 24) e correlações das dimensões com variáveis de habitat. Dimensão 1 × Dimensão 2 


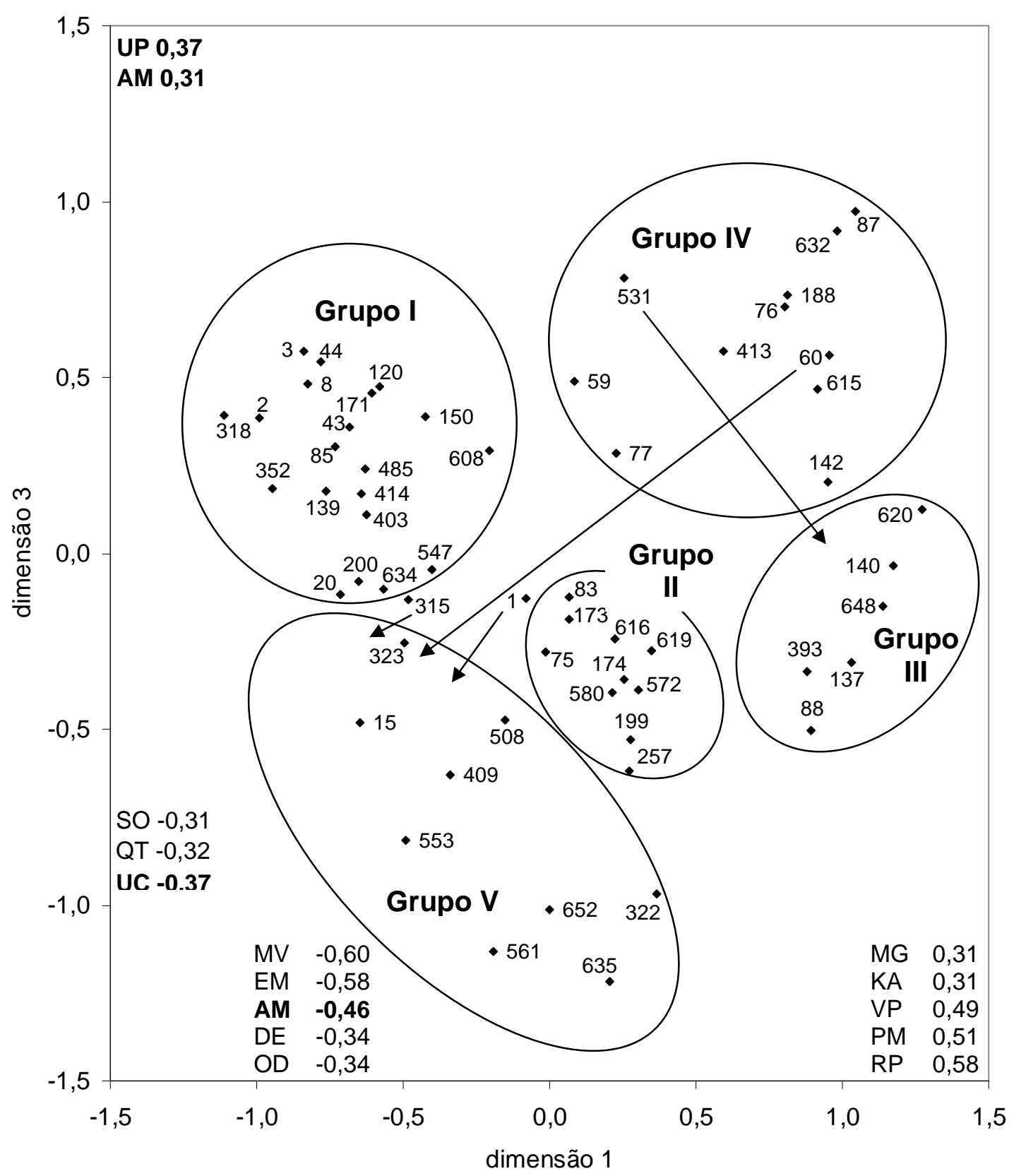

Figura 42 - Ordenação por escalonamento multidimensional não métrico (NMDS) de 58 amostras de peixes de riachos da Bacia do Rio Corumbataí, SP, obtidas nas estações secas de 2003 e 2004. São ilustrados agrupamentos obtidos por análise de cluster (Figura 24) e correlações das dimensões com variáveis de habitat. Dimensão 1 × Dimensão 3 


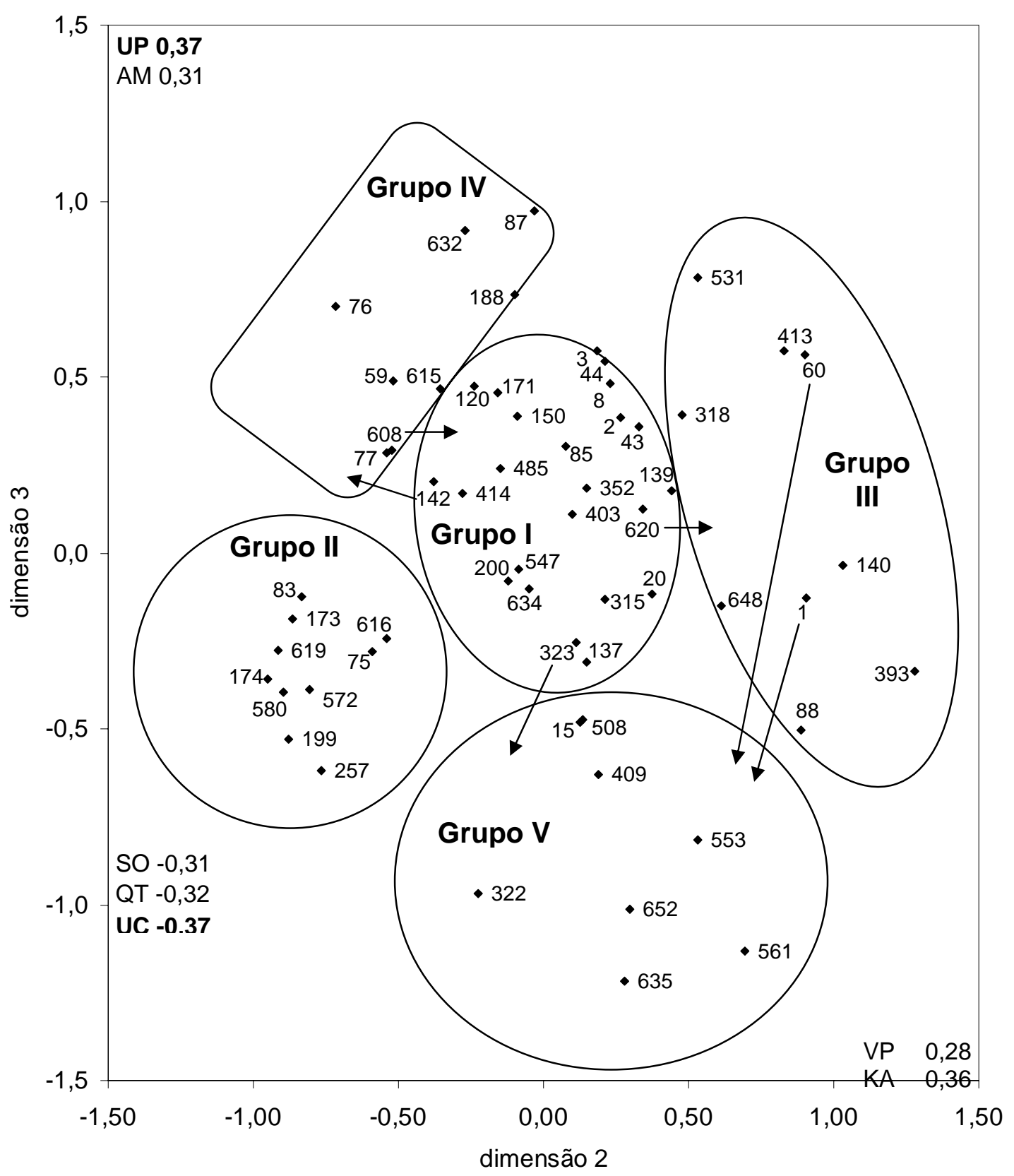

Figura 43 - Ordenação por escalonamento multidimensional não métrico (NMDS) de 58 amostras de peixes de riachos da Bacia do Rio Corumbataí, SP, obtidas nas estações secas de 2003 e 2004. São ilustrados agrupamentos obtidos por análise de cluster (Figura 24) e correlações das dimensões com variáveis de habitat. Dimensão 2 × Dimensão 3 


\subsubsection{Relações entre abundância, diversidade e estrutura das comunidades: um resumo}

De modo didático, através da Tabela 45 e buscando resultados das diversas análises (itens 4.3.5, 4.4.1, 4.4.2 e 4.4.3), foram relacionadas duas variáveis, elevação média (EM) e declividade geral (DG) das microbacias de cada agrupamento, como maneira de esquematizar dois dos principais eixos de variação na estrutura destas comunidades, a partir das quais foram produzidos dois esquemas didáticos nas Figuras 44 e 45 . O assunto será retomado na discussão, mas cabe citar que diversas variáveis descrevendo aspectos variados das microbacias amostradas apresentam covariação significativa a estas duas variáveis. Os resultados foram obtidas por técnicas variadas, conforme explicações nas Tabelas 37 e 44 e no item 4.3.2 do texto.

Tabela 45. Comparação de variáveis ambientais significativamente correlacionadas com descritores de abundância $(N)$, diversidade ( $H^{\prime}$ e $\left.G T\right)$ e similaridade de comunidades de peixes de riachos da Bacia do Rio Corumbataí

\begin{tabular}{|c|c|c|c|c|c|c|c|c|}
\hline Categorias & Variável & corr. $N$ & corr. $H^{\prime}$ & corr. GT & $R M H^{\prime}$ & Grupos & NMDS & $n$ \\
\hline \multirow{3}{*}{$\begin{array}{l}\text { Posição e } \\
\text { contexto da } \\
\text { microbacia }\end{array}$} & HS & & & & & $\times$ & $\times$ & 2 \\
\hline & SH & & $x$ & & & & & 1 \\
\hline & $\mathrm{DE}$ & & & & $\times$ & & $x$ & 2 \\
\hline \multirow{4}{*}{$\begin{array}{l}\text { Métrica de } \\
\text { microbacia }\end{array}$} & $\mathbf{E L}^{*}$ & & $x$ & $x$ & & x & & 3 \\
\hline & EM* & & & $x$ & & $\times$ & $x$ & 3 \\
\hline & DG & & & $x$ & & $\times$ & $x$ & 3 \\
\hline & CI & & $\times$ & & $\times$ & $\times$ & $x$ & 4 \\
\hline \multirow{8}{*}{$\begin{array}{l}\text { Uso e cobertura } \\
\text { do solo }\end{array}$} & UA & $x$ & & & & & & 1 \\
\hline & UC & & & & & & $x$ & 1 \\
\hline & UP & & $\times$ & $x$ & & & $x$ & 3 \\
\hline & UM & & & $x$ & & & $x$ & 2 \\
\hline & UF & & & & & & $x$ & 1 \\
\hline & $\mathrm{AM}$ & & & $x$ & & & $\times$ & 2 \\
\hline & $\mathrm{AJ}$ & & & $\times$ & & & & 1 \\
\hline & $\mathrm{CP}$ & & & $x$ & & & & 1 \\
\hline \multirow{2}{*}{$\begin{array}{l}\text { Geológicas e } \\
\text { pedológicas }\end{array}$} & ER & & $x$ & & & & & 1 \\
\hline & TS & & $x$ & & & & & 1 \\
\hline
\end{tabular}


Tabela 45. Comparação de variáveis ambientais significativamente correlacionadas com descritores de abundância $(N)$, diversidade $\left(H^{\prime}\right.$ e $\left.G T\right)$ e similaridade de comunidades de peixes de riachos da Bacia do Rio Corumbataí

\begin{tabular}{|c|c|c|c|c|c|c|c|c|}
\hline Categorias & Variável & corr. $N$ & corr. $H^{\prime}$ & corr. GT & $\mathrm{RM} H^{\prime}$ & Grupos & NMDS & $\mathrm{n}$ \\
\hline \multirow{13}{*}{$\begin{array}{l}\text { Parâmetros físicos } \\
\text { e químicos da } \\
\text { água }\end{array}$} & KA & & $\times$ & $\times$ & $x$ & $\times$ & $x$ & 5 \\
\hline & MG & & & & & & $x$ & 1 \\
\hline & $\mathrm{CN}$ & & & & & & $x$ & 1 \\
\hline & PH & & & & & & $x$ & 1 \\
\hline & OD & & $x$ & $x$ & & & $x$ & 3 \\
\hline & $\mathrm{CO}$ & & & $x$ & & & & 1 \\
\hline & SA & & & $x$ & & & & 1 \\
\hline & TG & & $x$ & & & & & 1 \\
\hline & $\mathrm{AT}$ & & & & & $x$ & & 1 \\
\hline & $\mathrm{AZ}$ & & & & & $x$ & & 1 \\
\hline & DU & & & & & $x$ & & 1 \\
\hline & CA & & & & & $x$ & & 1 \\
\hline & TU & & $x$ & & & & & 1 \\
\hline \multirow{6}{*}{$\begin{array}{l}\text { Métricas de } \\
\text { segmento }\end{array}$} & LP & & $x$ & $x$ & $x$ & & $x$ & 4 \\
\hline & SO & & $x$ & $x$ & $x$ & $x$ & $x$ & 5 \\
\hline & IS & & & & & $x$ & & 1 \\
\hline & $\mathrm{AB}$ & & $x$ & $x$ & & & & 2 \\
\hline & AP & & $x$ & & & & & 1 \\
\hline & $\mathrm{CV}$ & & & $x$ & & & & 1 \\
\hline \multirow[t]{14}{*}{ Métricas de canal } & PM & $x$ & & & $x$ & $x$ & $x$ & 4 \\
\hline & PX & & $x$ & $x$ & & $x$ & & 3 \\
\hline & $\mathrm{VC}$ & & & & & $x$ & & 1 \\
\hline & LM & & $x$ & & & & & 1 \\
\hline & $\mathrm{AC}$ & & $x$ & & & & & 1 \\
\hline & RP & $x$ & & & $x$ & $x$ & $x$ & 4 \\
\hline & PA & $x$ & & $x$ & & & $x$ & 3 \\
\hline & MV & & & & & $x$ & $x$ & 2 \\
\hline & QT & & & $x$ & & & $x$ & 2 \\
\hline & VP & & $x$ & $x$ & $x$ & $x$ & $x$ & 5 \\
\hline & PU & & & $x$ & & & $x$ & 2 \\
\hline & VE & & $x$ & $x$ & & $x$ & & 3 \\
\hline & OV & & & $x$ & & & & 1 \\
\hline & MS & $x$ & & & & & & 1 \\
\hline Totais & 50 & 5 & 19 & 23 & 8 & 19 & 24 & 50 \\
\hline
\end{tabular}

$n$ = número de vezes que a variável foi considerada significativa. Em negrito: variáveis que apareceram mais de três vezes. Variáveis marcadas com*: altamente correlacionadas ( $r$ de Pearson $=0,91)$. corr. $=$ correlação simples, $\mathrm{RM}=$ regressão múltipla, grupos $=$ análise de agrupamento e NMDS = escalonamento multidimensional não métrico. 
$\mathrm{Na}$ Figura 44, foram alocados os quatro agrupamentos de espécies (note-se a correspondência entre os grupos gerados nas análises dos conjuntos de amostras das estações chuvosas e secas, Tabela 25), considerando especialmente as variáveis EL (altamente correlacionada a EM) e DG. Foram citados, para os grupos I e II, algumas espécies exclusivas, e para todos os grupos, espécies dominantes, considerando os resultados obtidos em ambas estações (Tabelas 23 e 24). Neste diagrama, foram representadas variáveis ambientais (destacadas na Tabela 45), que foram associadas aos eixos da figura, indicando correlações positivas (setas) aos agrupamentos. A variável PA não foi incluída, pois não guarda relação precisa aos eixo de variação da figura. Foram incluídas as variáveis UC e UM, a fim de destacar aspectos relacionados ao uso do solo.

A Figura 45 detalha as associações de espécies (grupos), à altitude e à declividade média da microbacia. Podem ser categorizadas como: comunidades de altitudes elevadas (acima de 750 metros) e declividade acentuada (grupo I), comunidades ocorrendo em altitudes medianas (entre 700 e 650 metros) e com declividades acentuadas (grupo IV) ou brandas (grupo III) ou comunidades de peixes ocorrendo em baixas altitudes, menos de 650 metros e em terrenos bastante planos (grupo II). 


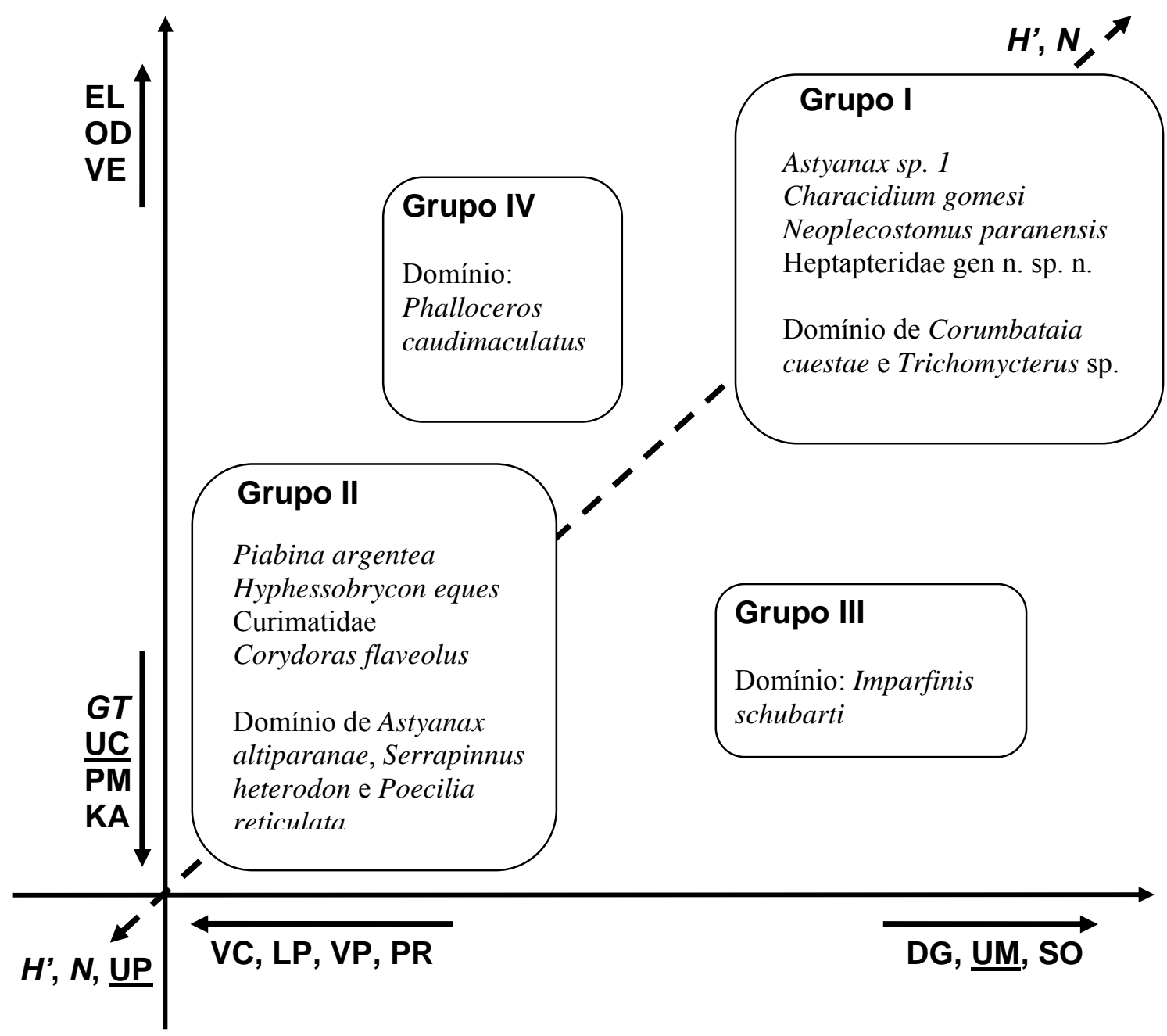

Figura 44 - Diagrama esquemático ilustrando relações entre eixos de variação de variáveis descritivas da diversidade e abundância de peixes de riachos (não há proporcionalidade dos eixos), e variáveis ambientais (selecionadas). Detalhes no texto 


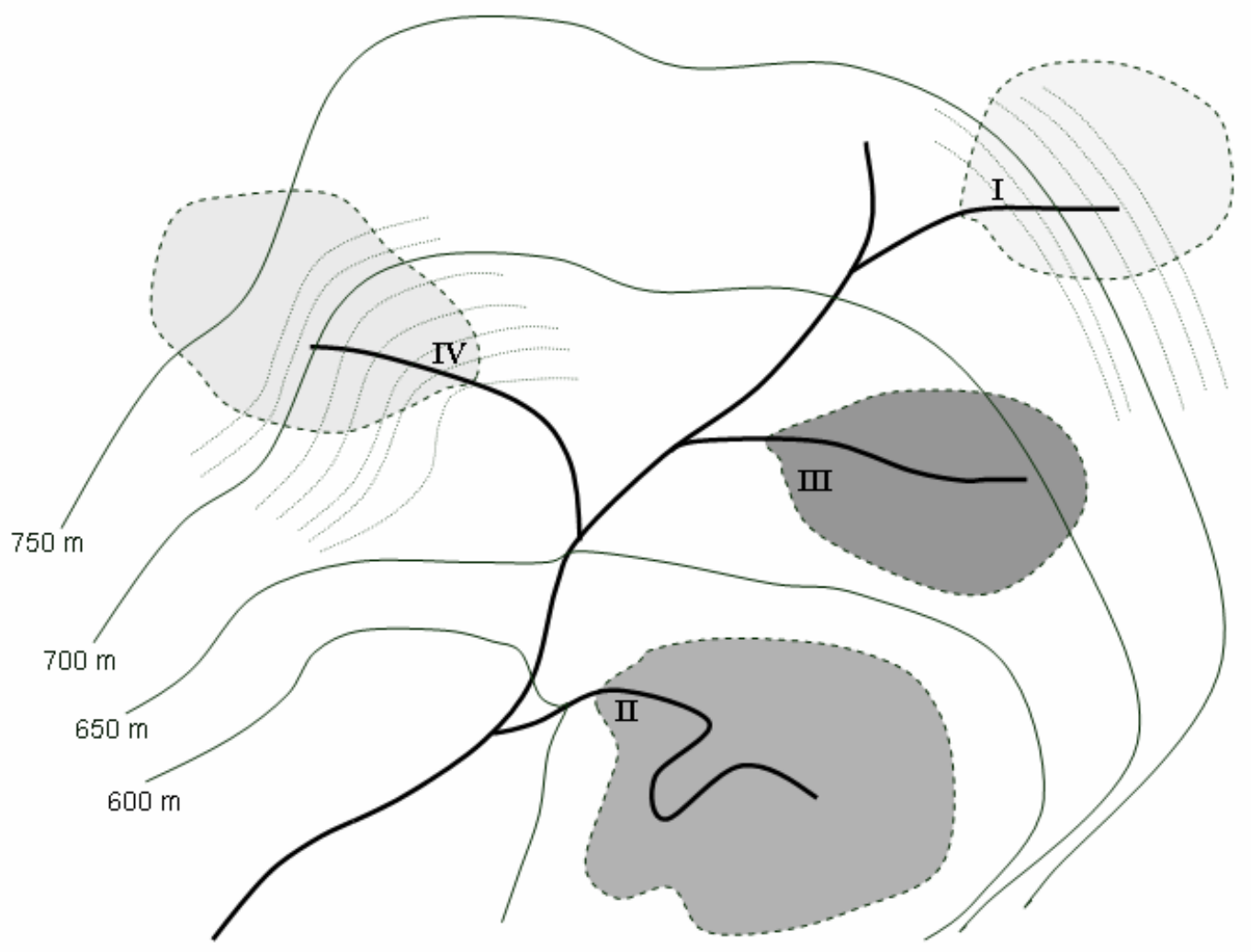

Figura 45 - Diagrama esquemático ilustrando a posição relativa dos agrupamentos (I, II, III e IV) obtidos nas análises ilustradas na Figura 23 e 24 (atentar para correspondência entre grupos), em função de elevação média e declividade geral das microbacias. As linhas claras indicam curvas de nível eqüidistantes. A linha mais escura indica a drenagem de uma sub-bacia contendo as diferentes categorias ilustradas

\subsection{Padrões geográficos de diversidade de peixes de riachos na Bacia do Rio Corumbataí}

\subsubsection{Diferenciação das comunidades entre riachos}

A Tabela 46 ilustra o índice de diversidade beta de Whittaker $\left(B_{W}\right)$ calculado para as seis sub-bacias estudadas neste trabalho e para o total de amostras obtidas da Bacia do 
Rio Corumbataí. O objetivo, neste ponto, é verificar a diversidade entre os ambientes (i.e., riachos) de cada sub-bacia, de onde se pode inferir possíveis efeitos do uso do solo em um nível da escala espacial maior do que o da microbacia. A análise é, entretanto, exploratória. Note-se que o índice $B_{W}$ não está diretamente relacionado ao número de espécies acumuladas ou a média de espécies por riacho por sub-bacia, nem tampouco ao tamanho da amostra. Destaca-se, na tabela a sub-bacia do Alto Corumbataí e a do Rio da Cabeça, respectivamente com o maior e o menor valor do índice. Há indícios fracos de que o índice esteja correlacionado à porcentagem de matas nativas da sub-bacia (Figura 46). Note-se que esta porcentagem é virtualmente a recíproca da porcentagem de terras com uso agrícola.

O índice correlaciona-se positivamente à variância da elevação dos pontos amostrais por sub-bacia $(r=0,82, p=0,04)$. Este último resultado relaciona-se à Figura 44, que ilustra a importância da variação de altitude e declividade na diferenciação da estrutura de comunidades de peixes.

Tabela 46. Número de rios amostrados $\left(n_{\text {rios }}\right)$, número de espécies acumuladas $\left(S_{\text {total }}\right)$, número médio de espécies $\left(S_{\text {médio }}\right)$ e índice de diversidade beta de Whittaker $\left(B_{W}\right)$, relativos a comunidades de peixes da Bacia do Rio Corumbataí, SP

\begin{tabular}{lcccc}
\hline Bacias & $n_{\text {rios }}$ & $S_{\text {total }}$ & $S_{\text {médio }}$ & $B_{W}$ \\
\hline Alto Corumbataí & 12 & 35 & 11 & 2.18 \\
Baixo Corumbataí & 12 & 38 & 17 & 1.24 \\
Rio da Cabeça & 8 & 24 & 13 & 0.85 \\
Médio Corumbataí & 6 & 35 & 16 & 1.19 \\
Passa-Cinco & 12 & 38 & 14 & 1.71 \\
Ribeirão Claro & 10 & 32 & 12 & 1.67 \\
Rio Corumbataí & 60 & 54 & 11 & 3.91 \\
\hline
\end{tabular}




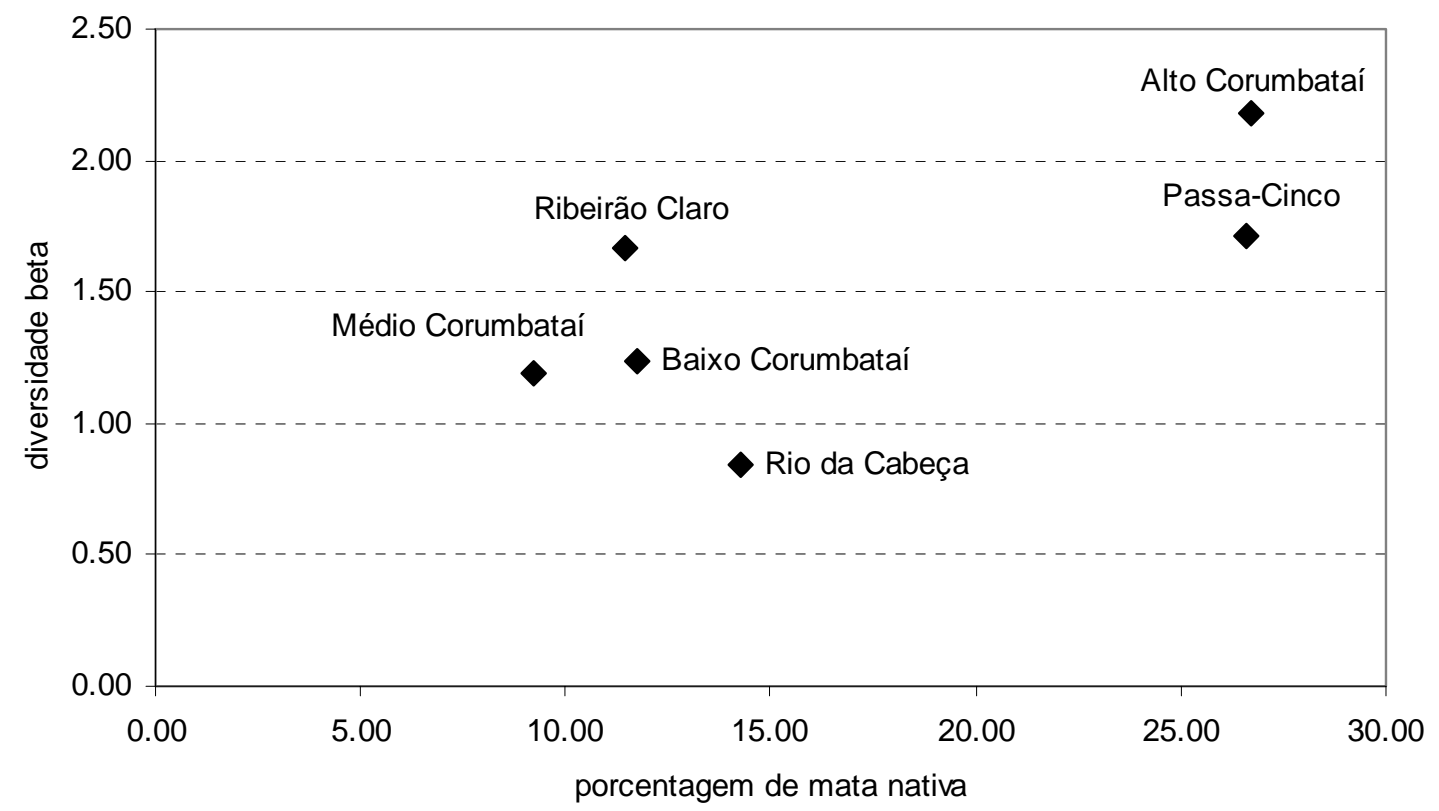

Figura 46 - Índice de diversidade beta de Whittaker por sub-bacias da Bacia do Rio Corumbataí e sua respectiva porcentagens em matas nativas. O coeficiente de correlação de Pearson é igual a 0,71 , não significante $(p=0,12)$

\subsubsection{Padrões geográficos nas comunidades de peixes}

As Figuras 47 a 49 ilustram a distribuição dos estados das variáveis descritivas $N, H^{\prime}$ e $G T$ em cada microbacia considerando sua disposição espacial na Bacia do Rio Corumbataí. Quanto ao número de indivíduos, não há padrões claros entre as sub-bacias. Em relação ao índice de diversidade de Shannon, destaca-se a sub-bacia do Baixo Corumbataí, a porção média da sub-bacia do Rio Passa-Cinco e a porção mais à montante da sub-bacia do Médio Corumbataí. Esta última também apresenta concentração elevada de riachos com grande número de grupos tróficos, tal como parte da sub-bacia do Rio da Cabeça. Grosso modo, os índices indicando diversidade ( $H^{\prime}$ e GT) ocorreram em regiões mais planas da Bacia do Rio Corumbataí, isto é, em locais relativamente afastados das cuestas. Nestes locais foram amostrados riachos de volume elevado, representando os canais do grupo II ilustrados na Figura 44. 


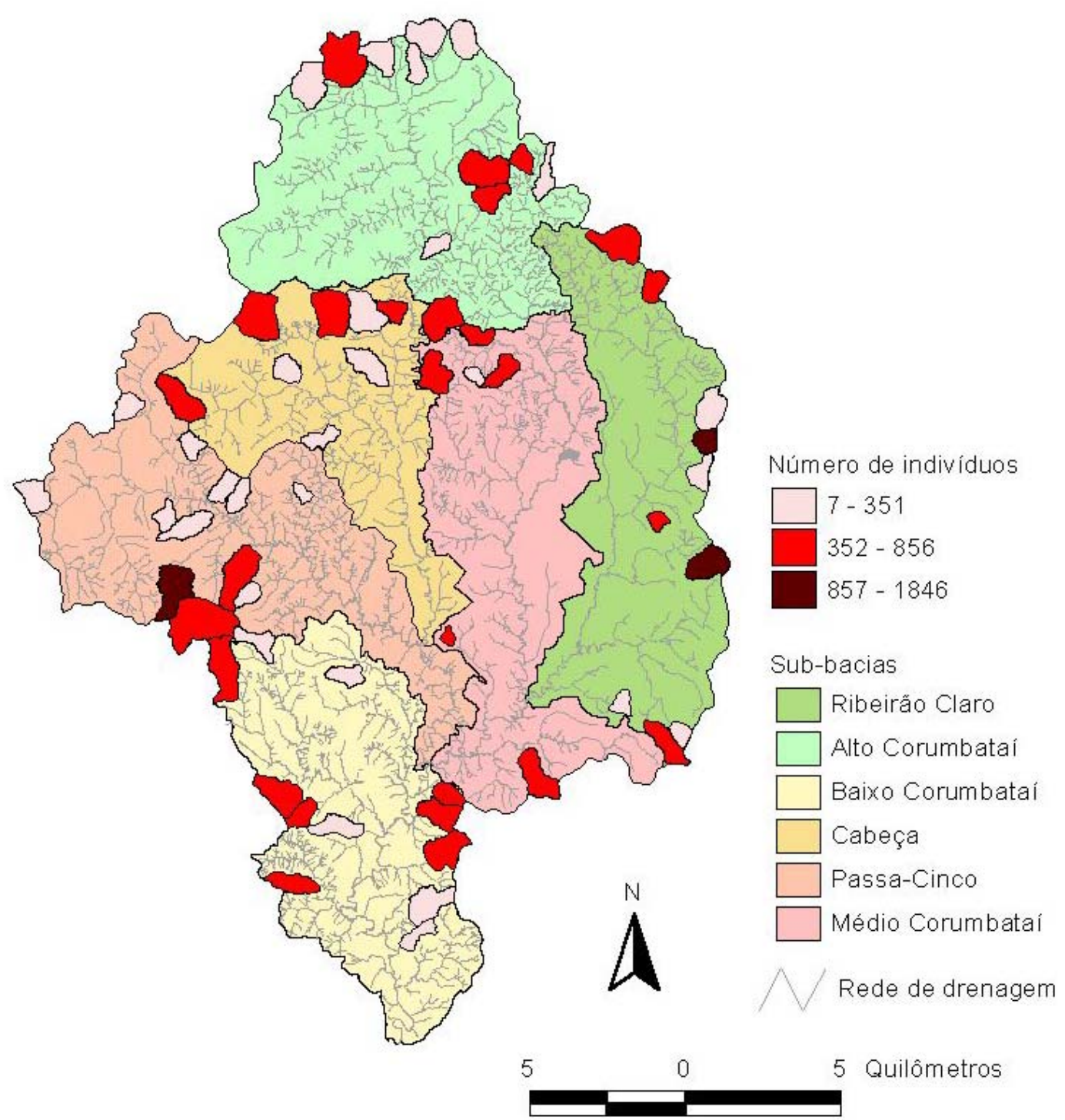

Figura 47 - Número de indivíduos por microbacias amostradas na Bacia do Rio Corumbataí, SP, destacando-se as sub-bacias a compõe. Os dados referem-se apenas às coletas efetuadas nas estações chuvosas de 2003 e 2004 


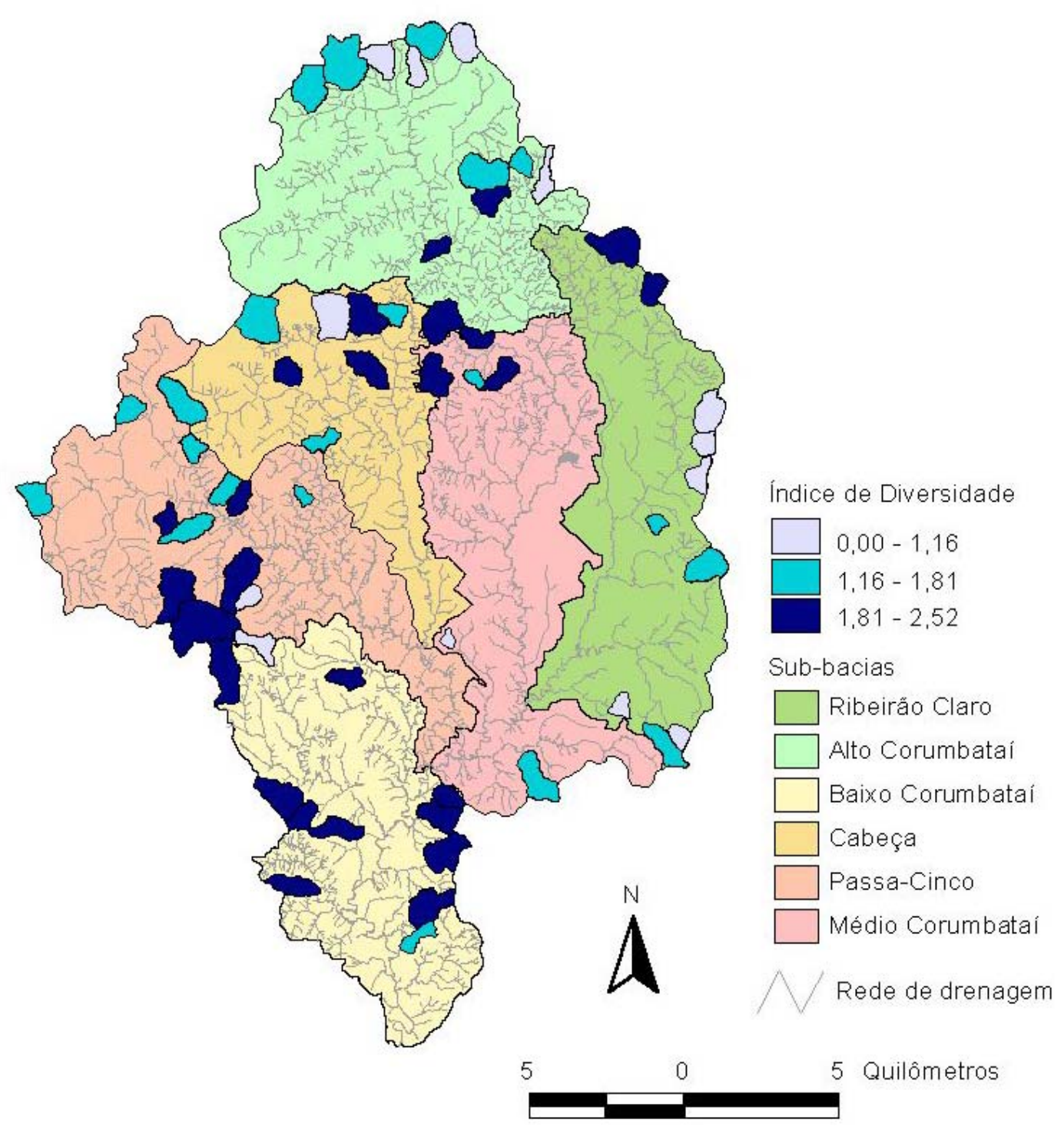

Figura 48 - Índice de diversidade de Shannon por microbacias amostradas na Bacia do Rio Corumbataí, SP, destacando-se as sub-bacias a compõe. Os dados referem-se apenas às coletas efetuadas nas estações chuvosas de 2003 e 2004 


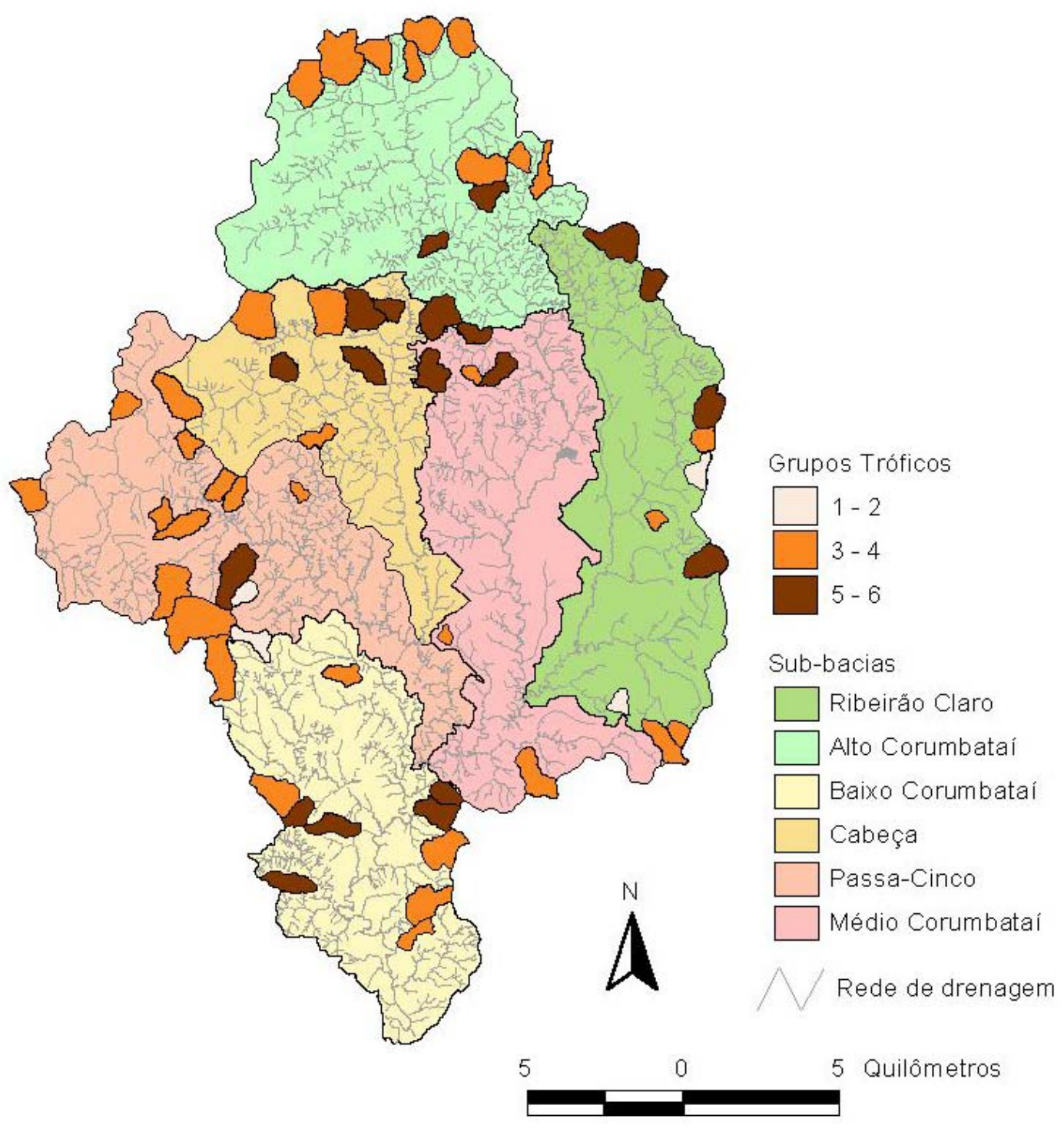

Figura 49 - Número de grupos tróficos por microbacias amostradas na Bacia do Rio Corumbataí, SP, destacando-se as sub-bacias a compõe. Os dados referem-se apenas à totalidade de amostras efetuadas nos anos de 2003 e 2004 


\subsection{Esforço de coleta e curvas de acumulação de espécies}

Estas análises tiveram como objetivo avaliar a representatividade da amostragem realizada neste estudo em termos do número de espécies de riachos da Bacia do Rio Corumbataí coletadas.

$\mathrm{Na}$ Tabela 47 é mostrado o número de espécies (total e acumulado) e de indivíduos totais coletados em cada campanha de amostragem. Nota-se que, grosso modo, na terceira campanha foi atingido o número máximo de espécies neste levantamento, não ocorrendo nenhuma espécie nova na quarta campanha. Como o número de amostras não foi constante ao longo das campanhas, estas informações devem ser vistas com cautela.

Tabela 47. Número de espécies $(S)$ total e acumulado, e de indivíduos $(N)$ de peixes amostrados em quatro campanhas de coletas na Bacia do Rio Corumbataí, Estado de São Paulo

\begin{tabular}{lcccc}
\hline Campanhas & $\begin{array}{c}\text { Número de } \\
\text { amostras }\end{array}$ & total & acumulado & $N$ \\
\hline Chuva 2003 & 25 & 40 & 40 & 10.593 \\
Seca 2003 & 38 & 46 & 48 & 21.518 \\
Chuva 2004 & 35 & 45 & 51 & 14.907 \\
Chuva 2004 & 20 & 34 & 51 & 6.788 \\
Total & 118 & 51 & 51 & 53.806 \\
\hline
\end{tabular}

Em uma análise mais detalhadas através do software EstimateS 7.00 (Colwell, 2004) foram obtidos os estimadores de Jacknife e Bootstrap para o conjunto de amostras das estações chuvosas e secas, que foram comparados ao total de espécies observadas para este mesmo conjunto. A partir da série de dados aleatoriezados da acumulação de espécies em função do número de amostras, ajustou-se uma função do tipo: $y=a\left(b-e^{-}\right.$ 
${ }^{\mathrm{cx}}$ ) através do software Curve Expert 1.3 (Hyams, 2003), a fim de se obter o valor assintótico da função quando x (número de amostras) igualava $10^{30}$. Este valor, denominado $S a$, também foi utilizado como um estimador da riqueza total de espécies do conjunto de amostras. A Tabela 48 mostra o valor obtido destes estimadores, e o percentual de espécies obtidas $\left(\% S_{o b s}\right)$ em relação a estes estimadores.

A Figura 50 mostra a curva de acumulação de espécies coletadas em função do número de amostras. Na legenda, foram citadas as equações correspondentes.

Tabela 48. Número de espécies observadas (Sobs) e estimadores de riqueza total de espécies pelo método de Jacknife, Bootstrap e valor máximo estimado a partir da função assintótica conforme as equações da Figura 50 (Sa). São mostrados os valores percentuais de espécies obtidas em relação a estes estimadores (\% Sobs)

\begin{tabular}{ccccc}
\hline & Sobs & Jacknife & Bootstrap & Sa \\
\hline Chuva & 51 & 57 & 54 & 52 \\
\% Sobs & - & 89.6 & 95.0 & 97.5 \\
Seca & 47 & 51 & 50 & 48 \\
$\%$ Sobs & - & 92.1 & 94.3 & 97.2 \\
\hline
\end{tabular}

Em resumo, a análise mostra que o esforço amostral empregado foi bastante satisfatório, seja para o conjunto das amostras obtida nas chuvas, seja para o conjunto de amostras obtida nas secas. Pela Figura 50, nota-se que o esforço de coleta empregado encontra-se já no "patamar" das curvas de acumulação de espécie, próximo à assíntota. Observaram-se pelo menos 89,6 \% das espécies estimadas pelo método de Jacknife na estação chuvosa e no máximo $97,5 \%$ das espécies estimadas pela função assintótica descrita na Figura 50. Note-se que o estimador Jacknife tende a produzir sobreestimativas do número total de espécies, especialmente quando o tamanho da amostra é pequeno. É possível afirmar com razoável dose de certeza que os riachos da Bacia do Rio Corumbataí abrigam, no seu conjunto, algo entre 52 e 54 espécies, considerando microbacias de tamanho equivalente às estudadas no presente estudo. 


\section{A) Chuvas: 60 amostras}

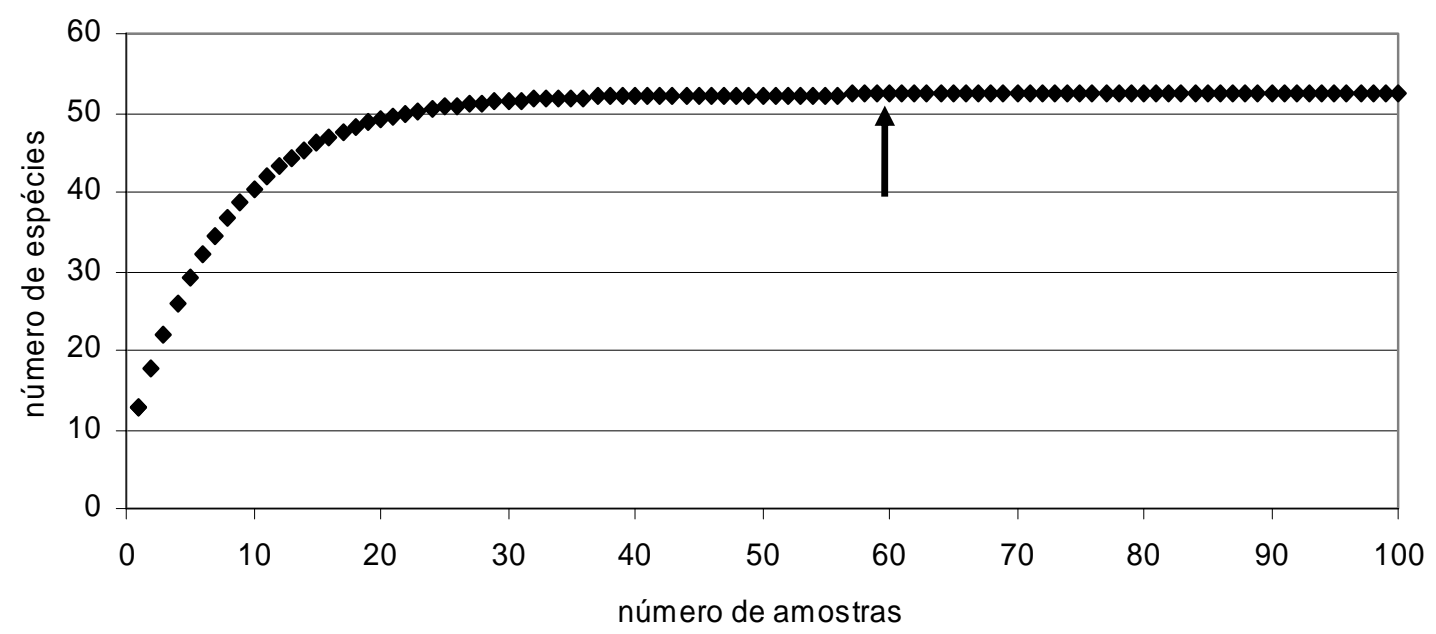

B) Secas: 58 amostras

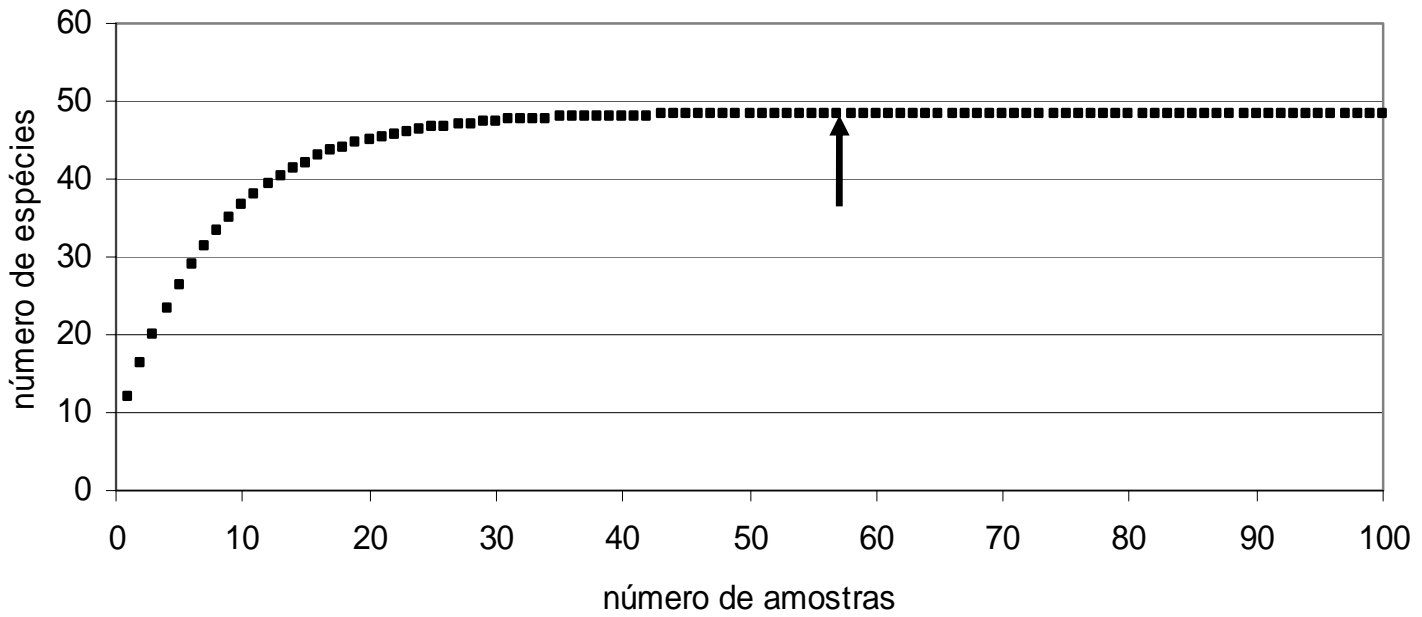

Figura 50 - Curvas de acumulação de espécies em função do número de amostras estimadas para o conjunto de amostras tomada na estações chuvosas (A) e secas (B) de 2003 e 2004, em riachos da bacia do Rio Corumbataí, SP. As curvas seguem as equações: A) $y=44,97\left(1,16-e^{-0,13 x}\right)$, com $r=0,99$ e B) $y$ $=41,31\left(1,17-e^{-0,12 x}\right)$, com $r=0,99$. As setas indicam o ponto da curva correspondente ao esforço amostral empregado 


\subsection{Efeitos da amostragem nas comunidades}

A Tabela 49 ilustra o resultado dos testes $t$-pareados conduzidos sobre os pares de amostras sobre uma mesma microbacias (diferença entre primeira e segunda coleta). Não foram observadas diferenças nas médias dos diferentes descritores de diversidade estudados, embora em relação ao número de indivíduos, pode-se citar o valor de $p=$ 0,12 .

Estes testes, entretanto, levam em consideração apenas a (diferença na) média dos descritores. Uma análise paralela, ilustrando a distribuição de freqüência das diferenças no número de espécies entre as coletas em uma mesma microbacia (Figura 51) revela que em cerca de $36 \%$ dos pares de amostras houve redução de uma a quatro espécies. A maior parte das variações entretanto, referem-se a diferenças entre estações secas e chuvosas. Ocorreu, tipicamente, redução no número de espécies quando a primeira coleta se deu numa estação chuvosa, e aumento do número de espécies quando a primeira coleta foi efetuada na estação seca. Um caso extremo de redução de espécies (-11 espécies) ocorreu em uma microbacia que sofreu uma enchente catastrófica que assoreou totalmente o canal amostrado.

Tabela 49. Resultados dos testes t-pareados sobre as variáveis-resposta N, H' e GT. Cada análise levou em consideração um medidas tomadas na primeira (anterior) e segunda (posterior) coleta em cada microbacia, constituindo, assim, 58 pares de amostras

\begin{tabular}{lccccc}
\hline & Média \pm Desvio- & $n$ & $t$ & $\mathrm{gl}$ & $p$ \\
\hline$N$ (posterior) & $406,59 \pm 356,21$ & & & & \\
$N$ (anterior) & $511,67 \pm 684,32$ & 58 & $-1,57$ & 57 & 0,12 \\
$H^{\prime}$ (posterior) & $1,56 \pm 0,56$ & & & & \\
$H^{\prime}$ (anterior) & $1,58 \pm 0,54$ & 58 & $-0,34$ & 57 & 0,73 \\
$G T$ (posterior) & $3,83 \pm 1,26$ & & & & \\
$G T$ (anterior) & $3,83 \pm 1,19$ & 58 & $3,4 \times 10^{-18}$ & 47 & 1,00 \\
\hline
\end{tabular}




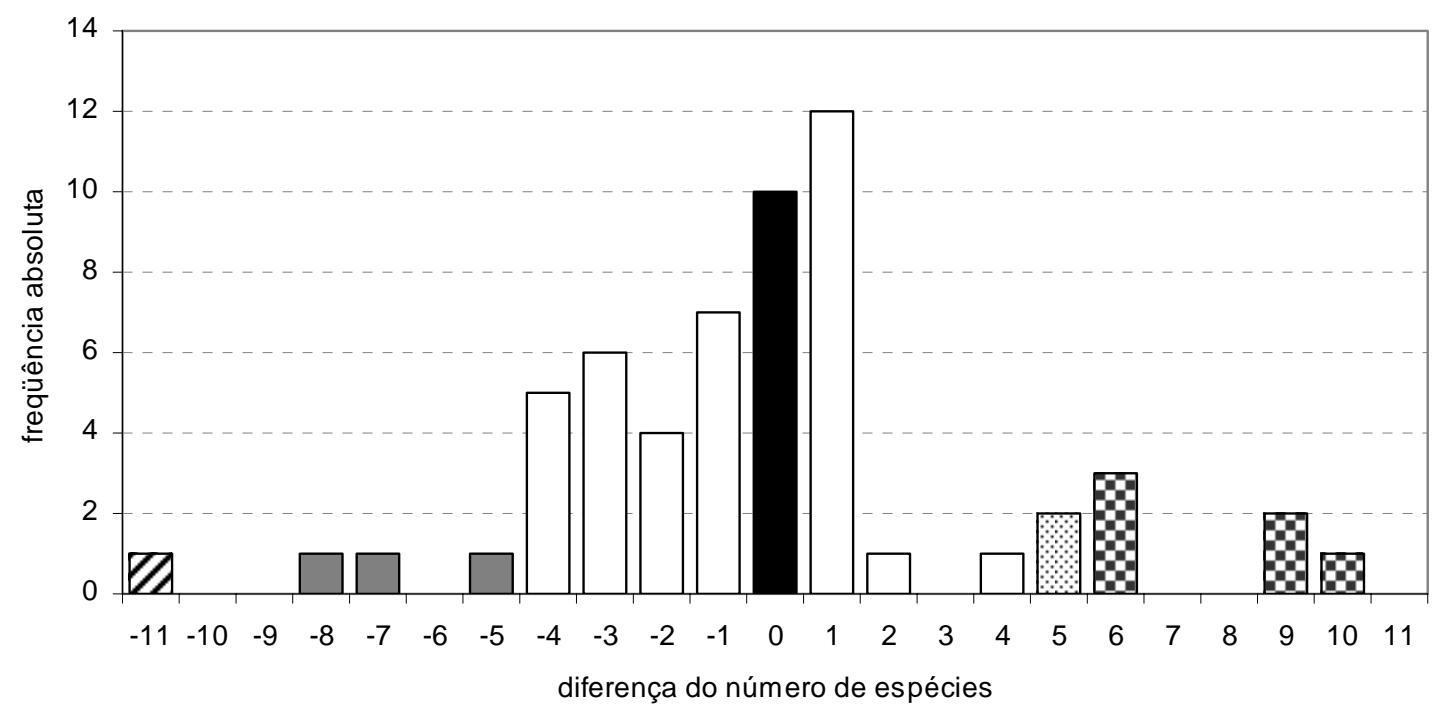

Figura 51 - Distribuição de freqüência das diferenças do número de espécies de peixes de riachos amostradas entre a segunda e a primeira coleta em uma mesma microbacia ( $n=58$ riachos), na Bacia do Rio Corumbataí. A barra preta indica ausência de diferença. As barras quadriculadas e em cinza escuro indicam diferenças relacionadas à primeira ou segunda coleta ocorridas nas estações secas e chuvosas, respectivamente. A barra pontilhada indica um caso para cada combinação de estações. A barra tracejada indica um caso onde ocorreu uma enchente catastrófica

A Figura 51 indica a necessidade de avaliar possíveis diferenças entre a estação chuvosa e seca. De fato, análises similares às da Tabela 49 indicam que há diferença significativa no índice de Shannon, sendo as amostras tomadas na estação seca menos diversas do que aquelas tomadas na estação chuvosa (teste $t$-pareado, com $t=3,84, \mathrm{gl}=$ $57, n=58, p<0,001)$. Quanto ao número de grupos tróficos, a probabilidade de a diferença ser devidas às estações é apenas marginal (teste $t$-pareado, com $t=1,81, \mathrm{gl}=$ $57, n=58, p=0,07)$. Não foram encontradas diferenças quanto ao número de indivíduos. Análises similares comparando os conjuntos de amostras tomados nos anos de 2003 e 2004 não revelaram quaisquer diferenças significativas, embora para o índice 
de diversidade de Shannon a probabilidade seja marginal, indicando que as amostras tomadas em 2003 são, em média, menos diversas do que aquelas tomadas em 2004 (teste $t$-pareado, com $t=-1,70, \mathrm{gl}=19, n=20, p=0,10)$. 


\section{DISCUSSÃO}

\subsection{Composição e estrutura das comunidades}

As comunidades de peixes amostradas neste estudo apresentam número de espécies, composição em número de famílias e ordens similares a diversos estudos realizados na região sudeste do Brasil, seja na bacia do Alto Rio Paraná (Castro \& Casatti, 1997; Casatti et al., 2001; Castro et al., 2003), Alto Rio São Francisco (Casatti \& Castro, 1998) ou entre as drenagens do Leste (Costa, 1987; Esteves \& Lobón-Cerviá, 2001; Gerhard et al., 2004). O padrão de distribuição entre ordens segue o da região Neotropical, com largo predomínio de Characiformes e Siluriformes, seguidos dos Gymnotiformes e Perciformes (Lowe-McConnell, 1987). Na maior parte das amostras, há predomínio dos Characiformes - notadamente Tetragonopterinae - onde os canais apresentam maior volume em relação ao perímetro do leito, sendo suplantados pelos Siluriformes quando a relação entre volume e perímetro é pequena, um padrão também recorrente em comunidades de peixes de riachos.

As amostras tomadas no presente estudo mostraram um número de espécies característico de riachos de cabeceiras de primeira a terceira ordens, aproximadamente entre uma e 26 espécies (média $=11,26$ ). Em um estudo bastante comparável, Castro et al. (2003) registraram entre cinco e 24 espécies, (média $=11$ ) para um conjunto de amostras de 17 segmentos de 100 metros de extensão de riachos da Bacia do Rio Paranapanema. Estes riachos apresentavam cobertura vegetal do entorno entre pastagens, fragmentos de matas nativas e culturas anuais, mas baseando-se nas fotografias daquele trabalho, aparentam ser trechos, na média, mais preservados do que os estudados no presente trabalho. Contrariamente ao verificado aqui, Castro et al. (op. 
cit.) atribuem o valor máximo de riqueza encontrada em seu estudo ao fato de que aquele rio está bastante próximo à foz de um rio de maior porte, e também por estar inserido em um fragmento de mata de cerca de 900 hectares. No presente, há uma fraca relação (negativa) entre tamanho de fragmento florestal (na microbacia) e riqueza de espécies, entretanto, foi encontrada relação significativa (negativa) com a distância entre os trechos amostrados e tributários de ordem maior ou igual a quatro. Em resumo, o número médio de espécies encontradas é compatível ao verificado para riachos próximos ao limite entre as regiões Tropical e Sub-Tropical da região Neotropical. O que não é explicitado, na maior parte destes estudos, é o estado atual e o histórico de degradação ou fragmentação da vegetação nativa destes locais. Seria este número médio próximo daquele encontrado em sistemas íntegros?

No presente estudo foram detectados quatro agrupamentos de espécies pelos riachos, sendo um deles bastante diferenciado dos demais. Não se trata de determinar que se tratam de associações determinísticas, interativas, ou mantidas por interações bióticas entre as espécies. É assumido, meramente, que se tratam de associações de espécies coexistentes por seleção individual de cada indivíduo das diferentes populações amostradas.

Trata-se de um número razoável de sustentar (como hipótese de comunidades ou agrupamentos de espécies discretos), e uma vez que os riachos aqui estudados apresentam tamanho bastante regular entre si, pode-se falar em quatro tipos de comunidades de peixes de riachos da Bacia do Corumbataí. Há uma distinção entre comunidades em riachos ocorrendo em áreas de altitude elevada e declividade acentuada (Grupo I e, possivelmente, IV), e outras, ocorrendo em riachos desenvolvendo-se em regiões mais planas, mais baixas. Aparentemente, trata-se de um padrão recorrente, observado por exemplo em comunidades de peixes da Carolina do Norte (Scott, 2001), da Virgínia do Oeste (Snyder et al., 2003), e em riachos bastante preservados da região sul do Estado de São Paulo (Gerhard et al., 2004). Também é possível correlacionar estes dois agrupamentos às duas classes de relevo citadas por Koffler (v. Área de Estudo). 
É possível também que a diferenciação entre estes agrupamentos possa manter relações com morfologias específicas de canais (cf. classificação de Hawkins et al., 1987, por exemplo), tipos de solo e/ou associações a tipos de uso e cobertura do solo, incluindo formações vegetais nativas não diferenciadas no presente estudo (cf. Rodrigues, 1999). Parte destas associações podem ser observadas nas figuras ilustrando a análise de NMDS. Vale notar que no presente estudo não foram realizadas análises visando detectar morfologias discretas de canais, que podem indicar conjuntos de características ambientais semelhantes, determinada primordialmente por fatores como relevo, que determina, em parte, as diferentes formas de uso de solo para atividade humanas.

\subsection{Uso e cobertura do solo e comunidades de peixes}

A forma como o uso e a cobertura do solo pode afetar as comunidades de peixes de riachos foi abordada de diferentes maneiras, seja pela cobertura dominante na microbacia (variável CD), seja pela comparação entre o predomínio de pastagens ou matas nativas na zona ripária (comparação entre microbacias de pastagens $\times$ ripárias) ou pelo tipo de vegetação predominante nesta zona (variável DB, que inclui os canaviais). Também foram realizadas análises sobre a porcentagem de cada cobertura na microbacia, além do índice de dominância entre os diferentes tipos de coberturas. De forma geral, foi constatado que as interações são mais fortes entre indicadores de diversidade em termos de espécies ( $\left.H^{\prime}\right)$ e de grupos tróficos $(G T)$ e a vegetação na zona ripária, embora tenham sido encontradas diferenças menos marcantes para as mesmas variáveis em relação a $\mathrm{CD}$.

Deve ser ressaltado que na aplicação das análises de variância (ANOVA), foi constatado a ocorrência de baixo poder dos testes, o que afeta a taxa de erro tipo II. Este erro pode ser definido como a probabilidade de rejeitar a hipótese de diferenças reais (= aceitar hipótese nula) nos casos em que há uma diferença real entre os tratamentos (= hipótese nula é falsa). Este não é um problema no caso da variável GT, onde foi aceita a hipótese alternativa de diferenças significativas entre as coberturas dominantes. Há, sim, 
problemas em relação a $N$ e $H^{\prime}$. Neste caso, é possível que os resultados obtidos neste estudo sejam interpretados como: "O uso do solo não interfere na abundância e na diversidade de peixes de riachos". Estas considerações podem ter implicações práticas em políticas envolvendo o manejo do uso do solo em áreas agrícolas, com relação aos sistemas lóticos. Neste caso, é mais prejudicial afirmar que não existem diferenças na riqueza de espécies entre rios drenando microbacias cobertas com mata nativa e rios drenando microbacias cobertas por canaviais, do que afirmar falsamente que estas diferenças existem (erro do tipo I). Incorrer no erro do tipo II significa sugerir que não importa o tipo de uso do solo, que a riqueza de espécies de peixes não será afetada, quando isto é, na realidade, falso (Caughley \& Sinclair, 1994).

Deve ser destacado que a aceitação da hipótese nula se deve à maior variabilidade intragrupos (grupos: microbacias de predomínio de canaviais, pastagens e matas nativas) em relação à variabilidade entre grupos, a respeito do estado das variáveis descritivas de diversidade e abundância. É necessário buscar as possíveis origens destas fontes de variação. Assim, a seguir, foram tecidas algumas considerações sobre esta questão:

1. A variável CD não caracteriza adequadamente as microbacias pela dominância de cada um dos tratamentos testados. Isto é, nesta escala de análise, CD variou entre $38,1 \%$ a $89,0 \%$ de cobertura por canaviais nas microbacias categorizadas como "canaviais", entre 43,7 \% e 90,5\% de cobertura de pastagens nas categorizadas como "pastagens" e entre $37,9 \%$ a $66,5 \%$ de matas nativas naquelas cunhadas como "nativas". Uma vez que o estudo trata de uma interação indireta (meio terrestre $\times$ aquático), este é um fator crucial para as comparações pretendidas neste estudo. $\mathrm{O}$ baixo poder dos testes calculados indica, justamente, elevada variabilidade intragrupos. Estes números refletem, também, o grau de fragmentação da paisagem da bacia.

Isto é, segundo esta hipótese, não seriam encontradas diferenças (médias) nos descritores (entre os grupos), pois não existe diferenciação efetiva entre as microbacias capaz de produzir efeitos significativos na riqueza, na diversidade ou na abundância de peixes de riachos. Todas as microbacias estudadas apresentaram-se como um mosaico 
complexo de formas de uso do solo e cobertura e, neste caso, devem oferecer condições (médias) similares de manutenção das espécies no habitat aquático.

2. Interação entre uso do solo e geologia, relevo e localização das microbacias. Isto é verificado prontamente analisando-se o mapa de uso do solo. Desta forma, certos tipos de uso do solo só ocorrem em determinadas configurações destes (e outros) fatores. Por exemplo, foi observado que as microbacias de predomínio de mata tendem a ocorrer somente nas regiões de maior declividade geral. Resultado similares foram encontrados para o embasamento geológico predominante da microbacia (ER) e largura da planície de inundação no entorno do trecho amostrado (LP), por exemplo. Trata-se de um fenômeno de covariação dos estados ou processos dos ecossistemas, difícil de ser resolvido em trabalhos de campo em ecologia. O número elevado de amostras tomado neste estudo visou, em parte, evitar que estes efeitos fossem demasiados influentes nas análises finais. A alternativa seria tomar um número menor de riachos mais similares entre si, por exemplo, em determinadas classes de relevo ou tipos de solo. Esta aproximação no entanto, implica em obter conclusões válidas somente para estas condições.

3. Violações gerais dos pressupostos da ANOVA tipo 1 (efeitos randômicos), como a necessidade da escolha randômica de unidades amostrais e a independência de réplicas (autocorrelação espacial), não foram respeitadas neste estudo. No entanto, análises sobre a variância de descritores categóricos, se consideradas de forma relaxadas (cf. Sokal \& Rohlf, 1999) podem ser boas indicadoras da estrutura de dados complexos, orientando análises subseqüentes mais pormenorizadas, ou direcionadas ao estudo de fenômenos do funcionamento dos sistemas lóticos.

Parte dos problemas levantados em relação ao estudo da variável CD também devem ser ponderadas em relação à comparação entre as microbacias de pastagens e ripárias (hipóteses 1 e 2, ao menos). Não foi possível, por exemplo, determinar que as APPs das microbacias denominadas "pastagens" e "ripárias" apresentassem exclusivamente pasto e matas nativas, respectivamente. Isto também se apresenta como um ruído nas análises. Porém, neste caso, foram encontradas interações significativas entre a vegetação na zona ripária e $H^{\prime}$ e $G T$, além de $N$ na estação chuvosa, 
marginalmente. Ainda assim, as análises sobre o poder do teste revelaram que a probabilidade de ocorrência de erro do tipo II, neste caso, são relativamente baixas (ca. $35 \%$ ). Ainda que os resultados obtidos devam ser vistos com cautela, a forma de interação entre o tipo de vegetação na APP (ambiente florestal $\times$ pastagens) e os indicadores de diversidade estudados era, em parte esperada. Afinal, a retirada da mata proporciona maior insolação no canal, com implicações diretas na produtividade primária dos trechos dos canais amostrados (Allan, 1996). Trata-se, portanto, de uma quebra da continuidade de processos do ecossistema lótico, conforme o modelo de Vanotte et al. (1980). Este processo pode ser visualizado também a partir da hipótese de homogeneização dos ambientes lóticos, conforme discutido abaixo.

Particularmente interessantes foram os resultados obtidos em relação à variável DB), ainda que eles devam ser vistos com reservas, devido ao reduzido número de microbacias com predomínio de canaviais na APP $(n=3)$. De fato, das 19 microbacias estudadas com predomínio de canaviais, 11 (57,9 \%) apresentam predomínio de pastagens na APP, seis $(31,6 \%)$ apresentam matas nativas e apenas duas $(10,5 \%)$ apresentaram predomínio de canaviais (a terceira microbacia com predomínio de canaviais na APP é uma microbacia de predomínio total de matas nativas). Note-se que as pastagens representam a cobertura dominante $(56,5 \%)$ nas áreas de preservação permanente na Bacia do Rio Corumbataí (Projeto Corumbataí, 2001). É possível que a cana, uma cultura de manejo intensivo, com aplicação considerável de defensivos agrícolas traga efeitos adversos às comunidades lóticas quando cultivada muito próximo ao canal. As práticas pecuárias na região, a despeito da elevada tecnologia do agronegócio canavieiro, são bastante antiquadas em relação ao praticado no restante do Estado de São Paulo. Assim, encontram-se muitas pastagens não manejadas, provavelmente com baixa freqüência de manejo de pragas ou aplicação de corretivos e adubação do solo.

Um recente artigo publicado na revista Visão Agrícola traz dados somente do meio terrestre ao discutir os efeitos do cultivo da cana de açúcar na diversidade de grupos de vertebrados e invertebrados (Rossetto, 2004; citando dados da EMBRAPA). Segundo estes dados, não são encontradas diferenças significativas entre a riqueza de 
espécies em canaviais e outros tipos de atividades agropecuárias. Enfim, pelo delineamento aplicado no presente estudo, fica em aberto a questão da interação entre canaviais nas APP's ao longo dos rios e diversidade de peixes, sendo requisitado um estudo focado no teste desta hipótese.

O presente estudo, até este ponto, entra em desacordo direto com aqueles publicados pelo grupo do pesquisador Gene Helfman, da Universidade da Georgia, EUA. Este grupo tem realizado estudos sobre o efeito da retirada das matas e a diversidade de peixes dos estados da Carolina do Norte e Tennessee, sempre verificando relações significativas e negativas entre as variáveis (Harding et al., 1998; Jones et al., 1999; Scott, 2001). O que deve ser ponderado entre estes estudos e o presente é o histórico e a duração da degradação ambiental da área em questão. É provável que, em um primeiro momento após o desmatamento ocorra a maior variação de um estado a outro, com perda acentuada de espécies sensíveis. Após este impacto inicial, um novo ponto de equilíbrio dinâmico deve ser atingido em termos de, por exemplo, variações microgeográficas de relevo, qualidade da água, regimes de temperatura da água. Este processo por levar até décadas para se completar (Fitzgerald et al., 1998; McCleary et al., 2004), mas resulta em seleção de espécies adaptadas à estas novas condições (Simon et al., 1995; Scott et al., 2001).

\subsection{Grupos tróficos}

O uso e cobertura do solo teve efeitos aparentes na quantidade de grupos tróficos encontrados entre as categorias de microbacias consideradas. As microbacias de predomínio de pastagens destacaram-se. A maior discrepância envolve o grupo dos insetívoros e dos detritívoro-iliófagos. O primeiro grupo é dos mais abundantes em número de espécies e indivíduos, ocorrendo em todas as classes de microbacias, enquanto os segundos estão ausentes nas microbacias com matas nativas, seja por predomínio em sua área total ou em sua zona ripária.

Os insetívoros são peixes que se alimentam tipicamente de (formas imaturas de) insetos aquáticos, tão mais abundantes em riachos relativamente preservados, em cujo 
leito predominam substratos consolidados (rochosos) e/ou abundância de troncos caídos de árvores (Allan, 1996). Neste estudo os insetívoros encontrados foram alguns tetragonopeteríneos como Hyphessobrycon eques, Piabina argentea, o glandulocaudíneo Planaltina sp., os crenuquídeos Characidium zebra e C. gomesi, o ciclídeo Cichlasoma facetum, e os siluriformes tricomicterídeos Trichomycterus sp. e heptapterídeos Imparfinis schubarti, Cetopsorhamdia iheringi, Pimelodella sp. e o Heptapteridae gen. n. sp. n.. Duas destas espécies, I. schubarti e C. zebra, são abundantes, amplamente distribuídas e de importância em termos de biomassa. I. schubarti é também das espécies mais abundantes em microbacias de predomínio de canaviais, pastagens, matas nativas e ripárias, enquanto C. zebra aparece como espécie dominante apenas nas duas últimas categorias. Todos os demais insetívoros, sempre de ocorrência limitada a poucos riachos, não estão, da mesma forma, associados à riachos de maior cobertura por matas nativas, seja em área total, seja na zona ripária. Exceção seja mencionada para $C$. gomesi. Uma vez que os insetívoros são usualmente considerados como indicadores de integridade nos índices de integridade biótica (v. Karr \& Chu, 1999, para uma revisão), estes resultados apontam, de forma preliminar, que estas considerações sejam tomadas com cautela.

Em relação aos detritívoro-iliófagos, as três espécies de curimatídeos foram incluídas nesta categoria. Ocorreram sempre em riachos onde havia um desenvolvimento acentuado de poços, determinando canais de volume elevado, não confinados, em áreas de baixa declividade. Ocasionalmente ocorreram com relativa abundância $(>10$ indivíduos por amostra). Por se tratarem de espécies de hábitos relativamente especializados é possível que exista elevada correlação entre canais com grande quantidade de poços profundos e bolsões de matéria orgânica em estado avançado de decomposição, que constituem o lodo que é a base da alimentação destas espécies. Notese que estes bolsões podem ser favorecidos também pelo desmatamento, que favorece a produtividade primária do sistema nestes pontos na forma de tufos de algas e macrófitas que, uma vez mortas, tendem a se acumular nos mesmos poços onde cresceram. Assim, a ligação desmatamento-pastagem parece direta, já que é nestas áreas de declividade pouco acentuada que o desmatamento é mais intenso. Entretanto, há que se lembrar que 
os grande poços são mais comuns em canais de ordem superior a três, isto é, em ribeirões e rios. É postulado, portanto, que a relativa baixa densidade com que ocorreram estas espécies possa indicar que os locais amostrados no presente estudo representem limites de distribuição destas espécies, fator a ser ponderado nas discussões sobre a estrutura de comunidades (Matthews, 1998).

De qualquer forma, este estudo não tem como objetivo testar as respostas individuais de espécies às diversas características ambientais mensuradas. Foi realizada apenas uma análise simples sobre o número de grupos tróficos. A análise deve prosseguir, no futuro, detalhando a estrutura das comunidades por sua diversidade e similaridade em termos de grupos tróficos. Esta abordagem trófica pode ser analisada por virtualmente todas as técnicas apresentadas neste trabalho.

\subsection{Estrutura das comunidades}

Não foram detectadas diferenças claras nos padrões de dominância de espécies por abundância, a partir da comparação das inclinações das curvas de ordenação logtransformadas das diferentes categorias de microbacias consideradas. Entretanto, ocorreram mudanças na composição e na ordem das espécies mais abundantes, notadamente entre as microbacias onde predominam as matas nativas na zona ripária (microbacias ripárias). As análises sobre as curvas log-transformadas tratam de uma resposta média das comunidades locais, que foram somadas a fim de se obter os ranqueamentos ora apresentados, e podem ser cunhadas como "pseudocomunidades". Isto é, não pode ser admitido plenamente que cada comunidade de peixes reaja de modo idêntico à forma de uso e cobertura do solo, independente de outros fatores ambientais.

Outra maneira de analisar a estrutura das comunidades é através da similaridade entre pares de amostras, através de índices. As interações entre a similaridade e o uso e a cobertura do solo foram analisadas por métodos de ordenação baseados nestes índices, e foram indicadas interações entre aspectos do uso e cobertura do solo e as formas como as comunidades são estruturadas. 


\subsection{Espécies exóticas}

Outro aspecto a ser considerado, inflacionando a lista de espécies de uma localidade, é a presença de invasores, exóticos ou nativos. Note-se que ocorreu maior número de espécies não-nativas nas microbacias de pastagens: quatro, contra três nas microbacias de predomínio de canaviais, e duas para os grupos remanescentes, matas nativas e ripárias. Ainda que estes números não sejam expressivos, nem indiquem diferenças claras entre estes grupos, deve-se observar a presença de espécies como Tilapia rendalli e Oreochromis niloticus com máxima cautela, pois ocorreram até mesmo em riachos tão pequenos quanto os aqui estudados. Ressalte-se que ambas aparecem no catálogo virtual FishBase como pragas (pests), tendo sido relatados problemas causados em diversos países onde foram introduzidas (Froese \& Pauly, 2004).

\subsection{Diversidade de peixes e fatores ambientais}

Há uma considerável redundância nas diversas análises realizadas entre descritores de abundância e diversidade ( $N, H^{\prime}$ e $\left.G T\right)$ e fatores ambientais (análises de correlação, análise de regressão múltipla) e entre a similaridade das comunidades (análise de agrupamento, NMDS) e estes mesmos fatores. O emprego de abordagens analíticas variadas, neste caso com resultados congruentes, reforça o potencial efeito de variáveis selecionadas na determinação da diversidade e estrutura de comunidades de peixes de riachos da Bacia do Rio Corumbataí.

Correlação não implica em relação causal, isto é, há a possibilidade de que variáveis selecionadas como significativas na determinação de diversidade ou estrutura não serem biologicamente plausíveis. Neste sentido, foram discutidas especialmente as 13 variáveis destacadas na Tabela 45, que representam aquelas que foram repetidamente encontradas como significativas entre as diversas análises estatísticas.

Os resultados das diversas análises estatísticas apontam como importantes na determinação da diversidade de peixes de riachos, variáveis relativas à morfologia dos 
canais e química da água, densidade da vegetação ripária e relevo no entorno dos canais, uso e cobertura do solo, características de relevo e conformação das microbacias e aspectos relativos à posição relativa do ponto de amostragem e rios de maior porte. Assim como no presente, diversos trabalhos enfatizaram a influência de fatores diversos, isoladamente ou em conjunto, na diversidade e estrutura de comunidades de peixes de riachos (Lotrich, 1973; Gorman \& Karr, 1978; Angermeier \& Karr, 1984; Schlosser, 1982; Roth et al., 1996; Vadas \& Orth, 2000; Brown, 2000, Marsh-Matthews \& Matthews, 2001; Esteves \& Lobón-Cerviá, 2001; Zorn et al., 2002; entre outros). Entretanto, o modo ou a força com que os fatores correspondendo a diferentes níveis da escala espacial ou temporal atuam na determinação da diversidade de uma comunidade local variam entre regiões geográficas, o que é modulado também por atividades antrópicas ao longo destas (Angermeier \& Winston, 1998).

Aspectos do relevo (altitude do ponto de coleta, altitude média da microbacia e declividade geral da microbacia) e forma da microbacia (circularidade) apresentaram relações com a diversidade e estrutura das comunidades. Foram detectados agrupamentos característicos de espécies que devem corresponder à comunidades formadas por espécies que respondem de forma diferente a elevação (altitude) e declividade. A elevação e a declividade correlacionam-se negativamente aos índices de diversidade (e à biomassa total, v. Anexo H), mas também estão relacionadas à diferenciação de agrupamentos discretos de espécies. Isto indica que áreas muito declivosas e elevadas representam ambientes extremos aos peixes (refletido na baixa diversificação de grupos tróficos e espécies) mas que aí são encontradas espécies características destes ambientes. A declividade da microbacia, se traduzida diretamente à declividade média dos canais, condiciona fortemente a morfologia dos canais, incluindo o tipo de material dominante no leito dos rios.

O índice de "circularidade" de microbacias aparece correlacionado negativamente ao índice de diversidade. Este índice de forma de uma microbacia correlaciona-se diretamente com a intensidade dos picos de vazão no vertedouro da microbacia, de modo que quanto mais próximo de um círculo perfeito, mais elevados serão as enchentes que passam por ali. É possível, assim, que a forma da microbacia 
regule, em parte, a diversidade de peixes, impondo regimes de estresse diferenciados às populações que habitam trechos em microbacias com diferentes formas. Esta informação é importante na discussão que segue, mais abaixo, sobre a dinâmica de comunidades de peixes em ambientes lóticos de cabeceiras.

A largura da planície de inundação guarda relações diretas com a morfologia dos canais, determinando-a. É, por outro lado, resultado das condições do relevo (e, portanto, geologia, clima, vegetação) da microbacia. Têm implicações profundas no funcionamento dos sistemas lóticos, que podem ser compreendidos, pela largura da planície de inundação, determinando unidades funcionais de canais (Montgomery, 1988). Os canais menos confinados apresentam também maior porcentagem de ambientes deposicionais (influenciado a relação entre áreas de poços e corredeiras e o volume dos canais, portanto), os poços. Isto tem implicações no tempo de residência da matéria orgânica e água, regimes de temperatura e de enchentes. Ficou demonstrado que os agrupamentos I e II podem ser diferenciados fortemente pela declividade da microbacia, pela altitude no ponto de coleta e pela largura da planície de inundação. Isto pode indicar, por exemplo, porque as espécies dominantes do agrupamento II são pelágicas (ou demersais), enquanto que no grupo I, temos duas espécies bentônicas como dominantes, além de outras espécies exclusivas bentônicas, como Characidium gomesi, Neoplecostomus paranensis e o Heptapteridae gen. n. sp. n.

O sombreamento proporcionado por árvores sobre o canal relaciona-se indiretamente a largura da planície de inundação. Note-se como a variável relaciona-se com os diferentes tipos de uso do solo, com as implicações óbvias do relevo local. Está inversamente relacionado à presença de pastagens, pois é nos vales muito encaixados que o desmatamento não prosseguiu ou que permitiu que a floresta se recompusesse, apresentando-se em estados variados de regeneração.

A variável RP mede a proporção de área de poços em relação às áreas de corredeiras e run. Há indícios de que quanto maior a quantidade de poços, maior a diversidade e a abundância, com implicações na ocorrência de espécies adaptadas a estas condições, conforme discutido acima. Note-se que a quantidade de poços tende a igualar a quantidade de corredeiras em canais de morfologia com alternância típica (e completa) 
entre poços e corredeiras, o que tende a ocorrer em canais não confinados (planícies de inundação bem desenvolvidas), de menor gradiente (menor declividade geral). Outras variáveis representam a forma ou a estrutura do canal (profundidade média e variância da profundidade do canal), seja em sua constituição da vegetação emergente no canal, seja em termos do grau de assoreamento do leito (porcentagem de areia no leito). A variância da profundidade do canal, está fortemente correlacionada com a profundidade média e o volume do canal, mas tem um componente que indica a heterogeneidade ambiental em termos de tipos de (meso)habitats de maior ou menor profundidade. Maior variabilidade de profundidades pode indicar diversidade de micro-habitats, o que favorece a ocupação de espécies distintas em um mesmo segmento. Diversos tipos de vegetação pendente nos canais foram relatadas nestes estudo, variando entre raízes de árvores próximas ao canal até ramos de lírio-do-brejo (Hedychium coronarium). Tratase, assim, arriscado traçar uma relação precisa entre esta variável e a estrutura das comunidades, a despeito dela correlacionar-se à diversidade das comunidades.

A porcentagem de areia no leito do canal no trecho amostrado é uma das indicadoras do grau de assoreamento no local. De fato, a presença de grande quantidade de areia no leito correlaciona-se negativamente a indicadores de diversidade (somente na estação seca, entretanto) e à capacidade de suporte do sistema (em termos do número de indivíduos e biomassa total), com implicações na estruturação de algumas comunidades. A porcentagem de areia, entretanto, mostrou baixa relação com tipos específicos de uso do solo. Trata-se de um assunto passível de ser estudado em detalhes no futuro, pois muitos dos riachos desta região encontram-se absolutamente assoreados.

Duas variáveis relativas a parâmetros físicos e químicos da água apresentaram relações significativas com a diversidade de peixes: concentração de oxigênio e potássio dissolvidos na água. Vale ressaltar que não foram encontradas concentrações de oxigênio muito baixas (isto é, em termos de limites de tolerância fisiológica) nas amostras tomadas neste estudo. Ainda assim, este parâmetro correlaciona-se fortemente a condições fisiográficas locais, além do relevo, por um efeito indireto com a temperatura. É possível, outrossim que algumas espécies tenham preferências bastante definidas por águas com certo teor de oxigênio. Assim, observa-se a diferenciação das 
comunidades dos grupos I e II, associada à variação de OD. Em relação aos teores de potássio, fortemente relacionados aos indicadores de diversidade e também à estrutura das comunidades, é possível que, haja concordância às práticas agropecuárias em áreas mais planas, mais baixas, com maior porcentagem de pastagens e canaviais. Note-se que a concentração de potássio (juntamente com o sombreamento sobre o canal) pode viabilizar um aumento na diversidade através do aumento na produtividade do ecossistema, seja diretamente, no caso dos nutrientes, como indiretamente, no caso do sombreamento dos canais.

Há, certamente, diversos eixos de transformação induzidos pela conversão da paisagem natural em pastagens ou monoculturas de cana-de-açúcar não detalhadas presentemente. Estes eixos podem ter gerado os extremos observados em riqueza de espécies observadas, entre uma e 26. Por exemplo, este estudo evitou amostrar canais extremamente assoreados, onde o canal não era sequer definido. Entretanto, diversos canais em graus menores de assoreamento foram amostrados, sendo verificado baixo número de espécies e indivíduos, irrespectivo ao tipo de cobertura vegetal dominante na microbacia ou extensão de matas nas APPs. Isto é, há interações entre tipos de rochamatriz e solos na microbacia, uso e ocupação do solo, hidrologia e relevo, que são capazes de gerar condições extremamente adversas aos peixes. As Figuras 44 e 45 ilustram, parcialmente, as maneiras como diversas variáveis descritivas de habitat interagem. $\mathrm{O}$ uso e a cobertura do solo não são, desta forma, independentes de fatores condicionantes do relevo e geologia do terreno, por exemplo.

Assim, se o desmatamento condiciona certos tipos de morfologias de canais, também aspectos das rochas e do relevo local podem direcionar um canal ou segmento de canal em rotas diversas, seja para o assoreamento (transitório ou não) ou erosão (i.e., formação de poços), seja influenciando a dinâmica de suprimento de água e matéria orgânica. É o que resume o conceito de Domínios de Processos: na (escala da) paisagem, padrões sistemáticos de processos de distúrbios exercem influências distintas nos ecossistemas lóticos e ripários, que são condicionados por padrões de vegetação e formas fisiográficas (Montgomery, 1999). Isto implica que os processos de alteração no ecossistema lótico devem ser entendidos através de um conhecimento detalhado do 
relevo e geologia local e tipos de vegetação associadas. No caso deste estudo, apenas análises preliminares foram conduzidas. Entretanto, é necessário maior detalhamento quanto à morfologia própria dos canais sob diferentes condições de relevo e, portanto, forma de uso do solo. Somente desta forma será possível inferir adequadamente sobre as formas que as atividades antrópicas alteram a abundância, diversidade e estrutura de comunidades de peixes de riachos.

\subsection{Fragmentação e degradação das florestas nativas e peixes de riacho}

Parte da pequena diferenciação nos indicadores de diversidade e abundância de peixes entre as coberturas vegetais dominantes pode ser devida à qualidade de conservação dos fragmentos de matas nativas encontrados e à estrutura da paisagem da Bacia do Rio Corumbataí. Da mesma forma, esta linha de argumentação implica em hipóteses sobre os motivos das microbacia de predomínio de matas nativas apresentarem menos espécies e menor diversidade do que as demais categorias.

A paisagem da Bacia se apresenta intensamente fragmentada, seja pelo cultivo da cana-de-açúcar, seja pelo planejamento inadequado do uso do solo (Valente \& Vettorazzi, 2002; Cavalli et al., 2001), e intensamente degradada (Rodrigues, 1999). Contribuindo para o atual grau de degradação e fragmentação está, logicamente, o tempo de ocupação da região: pelo menos 200 anos desde os primeiros povoamentos ou cidades (Dean, 1977) e quase 100 anos extensivamente (Victor, 1975).

É possível que o longo histórico de desmatamento e uso da terra tenham causado extinções locais (Bacia do Rio Corumbataí), porém estas informações não são acessíveis. Existem poucos levantamentos detalhados na região e mesmo os esforços existentes são de pouco mais de 40 anos atrás. Não é arriscado supor que casos de extinção (entre os peixes da região do Médio Tietê, por exemplo) possam ter ocorrido e que a ictiofauna atual seja ao menos parcialmente simplificada de um grupo maior de espécies. 
No contexto deste trabalho é importante citar o tamanho reduzido dos fragmentos florestais: a média não ultrapassa 6,4 hectares em todas as sub-bacias, pouquíssimos com área superior a 85 hectares, sejam eles de cerrado ou dos diferentes tipos de matas nativas (Valente 2001). A integridade das matas merece destaque, como observado em campo, por exemplo: a microbacia 572, a que apresentou maior porcentagem de mata, $63 \%$, possui, na realidade, um fragmento extensamente alterado, com alta densidade de lianas não lenhosas, muitas clareiras, elevada incidência de poucas espécies heliófitas e pioneiras (observações pessoais).

Além disto, é freqüente a presença de gado bovino no interior de muitos dos fragmentos onde se amostraram os riachos, com conseqüências drásticas sobre o seu sub-bosque e, notadamente, junto aos corpos d'água (v. Trimble \& Mendel 1995, para uma revisão). Neste sentido, a microbacia 318, com 110 hectares, apresenta $91 \%$ de sua APP constituída por mata, mas seu riacho está intensamente assoreado, com 98,5\% do substrato constituído por areia, e profundidade média igual a 3,7 cm (variância 3,7 cm), ainda assim medidos durante a estação chuvosa, isto é, com nível pouco acima ao de base.

Assim, na média, é possível que as microbacias denominadas "nativas" não sejam capazes de suportar uma associação de espécies de peixes característica de ambientes florestais, seja porque os fragmentos de mata não têm tamanho suficiente para constituir uma floresta, seja porque esta mata não é capaz de oferecer recursos às espécies que, desta forma, não poderiam sobreviver na ausência de um conjunto de características proporcionada pelos ambientes florestais. Note-se que não foram detectadas espécies exclusivas de microbacias de predomínio de matas nativas. Em termos de associações florestais, por exemplo, seria possível supor que associações diferenciadas de espécies de peixes ocorressem originalmente nas Florestas Ripárias e nas Florestas Paludosas descritas por Rodrigues (1999).

Dentre as amostras tomadas neste estudo, cerca de três microbacias foram amostradas dentro de fragmentos de Floresta Paludosa, formação evidenciada pela ocorrência da palmeira Geonoma brevispatha (Rodrigues 1999), da samambaia-açú (Ciathea sp.) e da arácea costela-de-adão (Monstera sp.), comuns no sub-bosque desta 
formação. É possível que as florestas ocorrendo em áreas de várzea (junto com varjões), isto é, em planícies de inundação mais ou menos bem desenvolvidas (da ordem de dezenas de metros) podem ter sido preferencialmente desmatadas e drenadas para o cultivo de arroz, por exemplo. Neste caso, esta fisionomia pode ter sido uma das mais alteradas. As Florestas Ripárias, formação que ocorre em extensões variáveis ao longo dos canais fluviais pode ter sido relativamente menos degradadas quando ocorrendo em áreas mais declivosas e como corredores mais estreitos, como é o caso nos rios de cabeceira (Naiman, 1992). Neste estudo, diversos trechos de riachos escolhidos para amostragem ocorreram em vales confinados, freqüentemente com corredores de mata bem constituída. Foram observadas aí espécies características das Florestas Ripárias, como o ingá (Inga affinis), o guanandi (Calophyllum brasiliensis) e a sangra d'água (Croton urucurana), entre outras.

Estas formações, ocorrendo em situações de relevo e solo distintas, poderiam conter associações de peixes características não mais detectáveis, dado o grau de fragmentação e degradação de cada uma delas. Assim, por exemplo, nos locais de ocorrência de matas paludosas encontrou-se apenas associações de Astyanax paranae, Imparfinis schubarti, Hypostomus ancistroides, sendo este último substituído por Corumbataia cuestae e/ou Trichomycterus sp. em locais de maior declividade. Tratamse, portanto, de espécies comuns nas amostras coletadas, não exclusivas a esta formação.

A sugestão é de que, na hipótese de ocorrência de extinções de espécies de peixes (em nível da Bacia do Rio Corumbataí), aquelas mais dependentes de recursos exclusivos das matas, e também sensíveis a alterações físicas e químicas no habitat, que seriam proporcionadas em uma qualidade distinta das observadas atualmente, neste estudo. É razoável supor que o conjunto amostrado de espécies seja um selecionado préadaptado às condições dos ambientes lóticos em agroecossistemas.

\subsection{Homogeneização de habitat}

Scott \& Helfman (2001) apontam que paisagens muito alteradas podem causar homogeneização entre agrupamentos de peixes, por exemplo, entre espécies adaptadas a 
rios de planície e a rios de cabeceiras, em maior declividade. Neste caso, o desmatamento de uma bacia hidrográfica pode transformar segmentos de riachos de cabeceira - ambientes oligotróficos, de águas frias e sedimento grosseiro e consolidado em segmentos similares a rios de terras mais baixas - eutróficos, de produtividade elevada, temperaturas mais alta, e sedimentos finos. Isto permite que espécies adaptadas a rios de planície invadam trechos mais à montante. A homogeneização é um exemplo dos efeitos das alterações no funcionamento do ecossistema lótico como um contínuo (Vannotte et al., 1980), onde segmentos típicos de cabeceiras passam a se comportar como trechos de terras mais baixas. É aí que a produtividade autóctone é maior que a alóctone (produção > respiração), favorecida pela ausência de sombreamento da mata ripária, aumento da quantidade de nutrientes disponíveis via sedimentos (Lowrance et al., 1991) e elevação da temperatura da água devido ao aporte de energia solar no trecho.

$\mathrm{Na}$ ocorrência de homogeneização, a ictiofauna pode apresentar inflação do número de espécies localmente (diversidade alfa) e, ainda assim, ocorrer perda de diversidade beta, isto é, na diversificação entre ambientes de uma mesma região (Magurran, 1988). Note-se que foi encontrada uma elevada correlação positiva (mas não significativa) entre a porcentagem de matas nativas nas sub-bacias e o índice de diversidade beta. $\mathrm{O}$ resultado sugere a hipótese de que áreas menos alteradas guardam maior diversificação entre ambientes, o que pode determinar também, diferenciação entre associações de espécies, isto é, maior diversidade beta.

Índices, sejam eles simples como o número de espécies ou complexos, como os índices de integridade biótica, podem ter sua análise complicada por este fator. É preciso, portanto, conhecer aspectos detalhados da biologia das espécies analisadas como, por exemplo, tolerância à sedimentação, tolerância ao estresse térmico, preferência de habitats em condições naturais. É possível que para a maior parte das espécies de peixes da região do Médio Tietê estas informações jamais possam ser resgatadas, já que não é mais possível encontrar áreas-controle, não alteradas, para realizar comparações efetivas.

Deve ser citado ainda que, dentro do universo de riachos estudados, todos deveriam apresentar canais amplamente sombreados por Mata Ripária bem constituída, 
já que nenhum dos canais apresentou largura média superior a três ou quatro metros (em todos os casos em que a largura média foi superior a este valor, os canais estavam extensivamente assoreados). Desta forma, originalmente, todos os sistemas amostrados deveriam ser oligotróficos, com regimes de temperatura, aporte de água e matéria orgânica, e morfologia de canais amplamente controlados pelo ambiente florestal. Ainda, maior número de grupos tróficos e diversidade foi encontrada em trechos degradados (por pastagens, na ausência de mata na zona ripária), e a maior diferenciação diz respeito a grupos funcionais (provavelmente) próprios de segmentos de rios maiores, não sombreados, onde a produtividade tende a ser maior do que nos trechos de cabeceiras. É bastante plausível supor que o fenômeno de homogeneização de fauna tenha ocorrido na área estudada. Estes são fatos suficientes para fomentar um estudo dirigido à ocorrência da homogeneização da ictiofauna de sistemas lóticos, apesar de não ocorrerem sistemas bem preservados para se estudar a distribuição das espécies da região em um estado mais próximo ao original.

\subsection{Comunidades de peixes de riachos como conjuntos de espécies pré-adaptas aos estresse físico e químico}

Parte da pequena diferenciação entre os descritores de abundância, diversidade e estrutura das comunidades entre os tipos de cobertura vegetal estudados pode ser um efeito direto da biologia das espécies de peixes de cabeceiras (ordem 1-3), ou que ocorrem também em cabeceiras. Isto é, seriam espécies altamente adaptadas a fortes distúrbios físicos e químicos, com populações altamente resilientes e dotadas de mecanismos diversos de recolonização de ambientes de elevado gradiente.

É uma hipótese proposta por Schlosser (1990), baseada em atributos da história natural de peixes de cabeceiras do meio-oeste norte-americano. As comunidades de peixes nestes locais seriam mais variáveis temporalmente, dificultando a distinção entre efeitos dos impactos naturais dos antropogênicos (pontuais). O trabalho de Bretschko (1995), sobre dinâmica temporal de ecótonos terra/água na dimensão longitudinal dos rios também assegura que as espécies habitando áreas de cabeceira deverão ser mais 
adaptadas ao estresse hidráulico e ao caráter de mosaico (irregular) de distribuição de manchas de habitat.

Por outro lado, em rios de baixada (de ordem 5 ou maior), a previsibilidade dos pulsos de inundação podem ser responsáveis por maior estabilidade nas comunidades, que podem, então, ser estruturadas também por fatores bióticos (Allan, 1996). É nestes rios, também, que pode ocorrer maior diversificação das espécies de peixes (Ward \& Tockner, 2003). Neste sentido, Cetra (2003), encontrou relações positivas entre a qualidade da mata ripária e o número de espécies amostradas em trechos do Rio PassaCinco e do Ribeirão Claro, também na Bacia do Passa-Cinco.

Informações circunstanciais obtidas ao longo deste estudo indicam que, de fato, parte dos riachos amostrados apresentou elevada variabilidade (que pode ser verificada, no futuro, por testes estatísticos, comparando-se sítios mais ou menos alterados), especialmente entre a estação seca de 2003 e a chuvosa de 2004, quando diversos riachos amostrados sofreram enchentes catastróficas que atingiram toda a planície de inundação destes locais. Esta dinâmica, entretanto, pode e deve estar acentuada pelo uso da terra nestes locais. Schlosser (1990) indica que mais estudos de longo prazo são necessários a fim de se detectar a amplitude de variação na estrutura de comunidades de peixes de cabeceiras em riachos alterados e naturais.

Outro indicador de variabilidade nas comunidades é oferecido pela própria comparação dos resultados das análises estatísticas considerando o conjunto de amostras das estações secas e chuvosas. Temos, por exemplo, o caso das análise de regressão múltipla. O modelo construído para a estação chuvosa incluiu oito variáveis explicando cerca de 49 \% da variação dos dados, ao contrário do modelo construído para a estação seca, que contou com apenas três variáveis determinando $35 \%$ da variação da diversidade medida pelo índice de Shannon. Isto indica que no período da estiagem menos fatores são (claramente) dominantes na determinação da diversidade de peixes. Durante as chuvas, variáveis ligadas ao volume do canal e à profundidade aparecem como importantes na determinação de $H^{\prime}$.

Nesta linha, também pode ser citados os movimentos sazonais das espécies, é possível que movimentos de cardumes de algumas espécies (Astyanax altiparanae é a 
mais significativa) possa alterar consistentemente a estrutura das comunidades. Essa movimentação pode ser mediada por alterações hidrológicas nos canais, por exemplo, com aumento de vazão dos mesmos, denotada pelo aumento significativo da profundidade média (PM), área (AC) e volume (VC) dos trechos amostrados na estação chuvosa (testes $t$ pareados, com valores de $t$ variando entre 5,09 (PM), 3,44 (AC) e 6,50 (VC), todos com $n=57$ amostras, 56 graus de liberdade e $p<0,001)$. Neste caso, também, as espécies que realizam estes movimento são as de hábito pelágico, como as espécies do gênero Astyanax, tipicamente influenciadas por habitats pouco mais profundos e, eventualmente, a profundidade média.

Assim, elevada variabilidade temporal no volume e qualidade de habitat devem determinar profundamente a variabilidade na estrutura e composição das comunidades. Trata-se de uma questão não abordada neste estudo, mas de elevada relevância na conservação de espécies destes riachos em agroecossistemas.

\subsection{Uso do solo e hidrologia: perda de cabeceiras}

O Projeto Corumbataí (2001) discute dados sobre a hidrologia do Rio Corumbataí nos últimos 30 anos, indicando redução significativa de vazão média no período. Foi detectado pelo autor que pequenas drenagens na região do Médio Corumbataí encontram-se totalmente secas, o que pode ser devido ao rebaixamento da calha do próprio rio entre a cidade de Corumbataí e cerca de $20 \mathrm{~km}$ à montante da cidade de Rio Claro, projeto realizado pela CESP por volta de 1968. Diversos informações de caráter anedótico (a partir de proprietários, moradores da região há mais de 20-30 anos) indicam a redução da quantidade de água em pequeno córregos drenando áreas diversas das sub-bacias do Alto Corumbataí, Rio da Cabeça e Passa-Cinco.

Parte da redução de vazão observada no Rio Corumbataí é devida ao maior escoamento superficial, atestado pelo aumento gradual da turbidez no mesmo período (Projeto Corumbataí, 2001). Entre as causas do aumento no escoamento superficial podem ser citados a retirada progressiva das matas e o incremento da pecuária na região 
(compactação do solo), além do uso inadequado do solo, diagnosticado por Cavalli et al. (2001), por exemplo.

Faria \& Marques (1999) detalham os processos de desaparecimento de pequenos rios de cabeceira em áreas agrícolas, incluindo áreas de cultivo de cana-de-açúcar no Estado do Espírito Santo. Segundo estes autores, o processo de desmatamento (em rios de primeira ordem) age de duas formas: rebaixando o lençol freático e favorecendo o entulhamento por sedimento no fundo dos vales. Note-se que, devido à impermeabilização (efetuada, por exemplo, pelo pisoteio do gado ou máquinas agrícolas), a maior parte da água escoa superficialmente que, diminuindo a recarga do lençol freático, favorece a ocorrência de picos de vazão. Desta forma, há concentração temporal do deflúvio, e migração à jusante das nascentes, às vezes por quilômetros.

É possível, assim, que a redução de vazão e, conseqüentemente alteração da dinâmica hidrológica nas pequenas bacias (associada à intensa sedimentação em diversas áreas) cause redução progressiva de habitats, isto é, redução do volume total do canal e redução da freqüência de poços por unidade de comprimento do canal. Isto também pode ser precipitado diretamente pelo desmatamento, já que é a mata ripária que fornece estrutura para a formação de poços nos riachos de cabeceira (Bisson \& Montgomery, 1996; Dahlström \& Nilsson, 2004).

Esta redução de habitat disponível pode deslocar as espécies pertencentes a guilda de peixes que utilizam poços, restando aquelas mais associadas ao substrato, bentônicas ou bento-pelágicas. Este é um assunto que merece detalhamento, e deve ter como base o conhecimento detalhado do uso de (micro) habitat pelas espécies de peixes da região. Efetivamente, haveria um "rebaixamento" dos limites de ocupação de certas espécies, que deveriam ocupar, assim, trechos de riachos onde ocorram poços de maneira significativa.

\subsection{Considerações finais}

Os modo como o uso e a cobertura do solo foram conduzidos e são manejados em agroecossistemas como o da Bacia do Rio Corumbataí produziram e produzem 
efeitos variados na abundância, diversidade e estrutura de comunidades de peixes de riachos. Não é possível, por outro lado, estabelecer uma linha divisória entre ambientes degradados e não degradados, tal é o grau de deterioração dos remanescentes florestais da região.

A forma como o terreno foi ocupado e o desmatamento processado impede que conclusões categóricas sejam realizadas. Isto porque o foi detectado que o principal eixo de variação entre abundância, diversidade e estrutura de comunidades está fortemente relacionado ao relevo e à altitude e, daí, a diversas características associadas a estes dois fatores. E, da mesma forma, o uso e cobertura do solo segue este mesmo eixo de diferenciação. Maior abundância e diversidade foi verificada entre os largos e volumosos canais de baixadas, não confinados, especialmente associados a pastagens, nas regiões do alto Médio Corumbataí, Baixo Corumbataí e Ribeirão Claro. Entretanto, é nestes segmento de canais que ocorreu maior alteração, especialmente na zona ripária. É aí, portanto, que a modificação do funcionamento do sistema lótico de oligotrófico a eutrófico pode ter condicionado a ocorrência de homogeneização, tendo sua diversidade local inflacionada por espécies (e grupos tróficos) próprios de ribeirões ou rios. Deve ser novamente ressaltado que nenhum dos canais estudados deveria receber insolação direta em condições naturais, portanto, as modificações no caráter produtivo destes riachos se deve às alterações antrópicas.

$\mathrm{Na}$ outra extremidade deste eixo apresentam-se os riachos confinados, em áreas de altitude mais elevada e mais declivosas, com maior ou menor extensão de Mata Ripária, em geral, mal preservada e, muitas vezes, com canais assoreados. As associações de espécies são, provavelmente, mais próprias de pequenos riachos de cabeceira, com diversidade de espécies relativamente elevada, mas com estrutura trófica menos diversificada. É nestes sistemas que os processos de degradação da mata, com implicações em sua dinâmica hidrológica podem ter levado ao desaparecimento de espécies dependentes do conjunto de recursos proporcionados pela mata, resultando em empobrecimento da ictiofauna.

Considerada a possibilidade de ocorrência dos processos de rebaixamento das cabeceiras e homogeneização de fauna, é possível lançar a hipótese de que as 
comunidades de peixes de riachos da Bacia do Rio Corumbataí estão sendo governadas por efeitos causados por distúrbios antrópicos ocorrendo em áreas à montante e à jusante de seu local de ocorrência.

\subsection{Perspectivas para estudos futuros}

Até este ponto, diversas questões foram levantadas, mas a diversidade e quantidade de informações coligidas ao longo deste estudo não foram totalmente organizadas até o presente. Assim, ficam diversas possibilidades para estudos futuros, novos, ou como aprofundamentos das análises aqui iniciadas. Podem ser citados:

1. Detalhamentos da interação entre uso da terra e diversidade de peixes de riachos. Há possibilidade de se analisar os dados obtidos no presente trabalho em relação à configuração dos elementos da paisagem dentro de cada microbacia de predomínio de pastagens. Há evidências consideráveis de que a disposição diferencial de um fragmento de mata em uma microbacia produza diferentes impactos no sistema lótico, em relação ao ponto de ocorrência de distúrbios (S. Ferraz, 2004). Outra aproximação trata de avaliar a interação uso da terra $\times$ diversidade de peixes a partir do conjunto de dados coletados, mas orientada por uma sub-divisão em blocos de riachos ocorrendo nas diversas situações de relevo, por exemplo, categorizadas pela largura de planície de inundação;

2. A abordagem sobre grupos tróficos deve ser detalhada. A análise deve seguir ao se computar também a diversidade ( $H^{\prime}$, por exemplo) e a estrutura (análise de agrupamento) das comunidades por grupos tróficos, que será relacionada ao uso e cobertura do solo. Também são necessários estudos detalhados visando compreender a produtividade do sistema lótico e a oferta de recursos alimentares do meio terrestre sob microbacias que apresentam usos e coberturas vegetais variadas;

3. Foram discutidos três fenômenos relacionados ao funcionamento dos sistemas lóticos: 1. Dinâmica temporal na estrutura das comunidades ou populações de peixes, agravadas ou não por atividades antrópicas, 2. Homogeneização da ictiofauna por alterações na continuidade natural dos riachos e, 3. Perda de cabeceiras por alterações na 
dinâmica hidrológica de microbacias. Todas as hipótese são relevantes, e pouco exploradas pela comunidade científica até o presente. Para serem testadas, é possível lançar mão do método comparativo, mas um conhecimento aprofundado de aspectos da biologia (dieta, comportamento alimentar, modos de reprodução, área domiciliar e de vida e preferências e uso do habitat) das espécies é urgente e necessário;

4. Algumas coletas e peixes foram realizadas na região da Bacia do Rio Corumbataí desde há cerca de 40-60 anos por pesquisadores de instituições de pesquisa do Estado de São Paulo. A existência de bases de dados aerofotogramétricos a partir da década de 50 ou 60 do século XX possibilita interessantes estudos comparativos sobre a interação entre ocorrência de espécies e características do uso e cobertura do solo;

5. Estudos sobre a fragmentação da rede hidrográfica da Bacia do Rio Corumbataí. É considerado que a bacia em estudo é extensamente fragmentada por ações antrópicas e que este processo é outra fonte de impacto às populações de peixes de riachos e ribeirões. A questão pode ser abordada ao ser verificada a correlação entre áreas com diferentes graus de fragmentação e padrões de diversidade alfa e beta, ou padrões de ocorrência de espécies.

6. Modelagem preditiva visando detectar padrões de distribuição baseados em conceitos de nicho ecológico, utilizando-se de dados de presença e ausência das espécies amostradas e variáveis (atributos) ambientais da bacia, à exemplo do estudo efetuado por K. Ferraz (2004). Os resultados permitirão levantar questões e elaborar hipóteses ecológicas que poderão ser testadas através de levantamentos rápidos no campo, utilizando o processo de tomadas de decisão em ações de manejo, zoneamento ambiental e/ou recuperação de áreas prioritárias à conservação. 


\section{CONCLUSÕES}

Em relação aos objetivos listados na Introdução deste trabalho, pode-se concluir que:

1. As comunidades de peixes de riachos amostradas apresentaram-se estruturadas em quatro (cinco na estação seca) agrupamentos. Todos podem ser relacionados a condições ambientais diversas, porém há uma diferenciação bastante marcada em função do relevo (altitude e declividade) e um conjunto de fatores que apresenta covariação com a conformação do terreno;

2. Foram detectadas interações significativas entre descritores de diversidade (de espécies e grupos tróficos) e uso do solo na microbacia. A maior diferenciação ocorre entre as microbacias de predomínio de pastagens e de matas nativas, mas a interação é mais forte quando se considera a presença de ambiente florestal ou agrícola nas zonas ripárias das microbacias. Menor diversidade foi encontrada nos ambientes florestais. Em geral, as análises sofreram de baixo poder estatístico, o que pode ser relacionado a alta variabilidade entre as microbacias, irrespectivo ao tipo de uso ou cobertura do solo. A forma de uso da terra não independe de fatores diversos como o relevo e o tipo de solo. Foi lançada a hipótese de que os riachos ocorrendo em áreas mais altas e mais declivosas sofrem com a perda de espécies devido à degradação do ambiente florestal, e que em riachos ocorrendo em áreas mais baixas e planas - as mais alteradas - há ganho de espécies características de ribeirões e rios, devido à ocorrência de homogeneização entre estes ambientes.

3. A diversidade e abundância de peixes mostrou-se influenciada por fatores tão diversos quanto a conformação do relevo do ponto de amostragem e da microbacia, a posição relativa do ponto de amostragem a tributários de maior 
ordem, química da água, estrutura da vegetação ripária e morfologia do canal. Há elevada covariação entre diversos destes fatores e o relevo, na forma de elevação e declividade. O relevo influencia, por sua vez, a ocorrência, a riqueza, a diversidade de peixes de riachos; e

4. Não foram encontrados padrões claros na diversidade (de espécies e grupos tróficos) e abundância de peixes em relação às sub-bacias do Rio Corumbataí. Entretanto, há indícios de que a diversidade de espécies entre os riachos esteja diretamente correlacionada à porcentagem de ambientes florestais nativos nas sub-bacias, notadamente Passa-Cinco e Alto Corumbataí. Entretanto, a diversidade beta está correlacionada significativamente à variação altitudinal dos pontos amostrados em cada sub-bacia. 
ANEXOS 
Anexo A. Data de amostragem de 60 microbacias da Bacia do Rio Corumbataí, de acordo com a cobertura predominante do solo. Quatro campanhas são consideradas, entre os anos de 2003 e 2004, nas estações seca e chuvosa. $n=$ número de vezes que cada microbacia foi amostrada

\begin{tabular}{|c|c|c|c|c|c|c|}
\hline & \multicolumn{3}{|c|}{2003} & \multicolumn{2}{|c|}{2004} & \multirow[b]{2}{*}{$n$} \\
\hline & ID & chuvosa & seca & chuvosa & seca & \\
\hline \multirow[t]{19}{*}{ cana } & 75 & & & $19-\mathrm{fev}$ & 7-jul & 2 \\
\hline & 83 & & & 27-jan & 24-jun & 2 \\
\hline & 85 & & & 27-mar & 6-jun & 2 \\
\hline & 120 & & & 23-jan & 5-jul & 2 \\
\hline & 174 & & & $17-\mathrm{fev}$ & 29-jul & 2 \\
\hline & 199 & & & 2-abr & 28-jul & 2 \\
\hline & 322 & 20-mar & 17-jul & & & 2 \\
\hline & 531 & & 16-jul & 28-jan & & 2 \\
\hline & 553 & 2-abr & 20-ago & & & 2 \\
\hline & 561 & & & 31-mar & 30-jul & 2 \\
\hline & 580 & & & $1-\mathrm{abr}$ & 26-jul & 2 \\
\hline & 608 & & 2-out & 9-mar & & 2 \\
\hline & 616 & $15-\mathrm{fev}$ & 26-jul & & & 2 \\
\hline & 619 & $13-\mathrm{fev}$ & 23-jul & & & 2 \\
\hline & 620 & 5 -fev & 31-jul & & & 2 \\
\hline & 632 & 4-fev & 25 -jul & & & 2 \\
\hline & 634 & 6-fev & & & 8-jul & 2 \\
\hline & 635 & & 1-out & 12-mar & & 2 \\
\hline & 652 & 7-fev & & & 14-jul & 2 \\
\hline \multirow[t]{11}{*}{ nativa } & 20 & & 26-set & 3-mar & & 2 \\
\hline & 44 & 26-mar & 8-ago & & & 2 \\
\hline & 173 & & 22 -set & 10-mar & & 2 \\
\hline & 200 & $26-\mathrm{fev}$ & 29-ago & & & 2 \\
\hline & 257 & & & $12-\mathrm{fev}$ & 27-jul & 2 \\
\hline & 323 & $28-\mathrm{fev}$ & 18-jul & & & 2 \\
\hline & 409 & & & 25-mar & 29-jun & 2 \\
\hline & 485 & $21-\mathrm{fev}$ & 27-ago & & & 2 \\
\hline & 572 & 25-mar & 29-jul & & & 2 \\
\hline & 615 & $11-\mathrm{fev}$ & 22-jul & & & 2 \\
\hline & 648 & & 5 -set & 6-fev & & 2 \\
\hline
\end{tabular}


Anexo A. Data de amostragem de 60 microbacias da Bacia do Rio Corumbataí, de acordo com a cobertura predominante do solo. Quatro campanhas são consideradas, entre os anos de 2003 e 2004, nas estações seca e chuvosa. $n=$ número de vezes que cada microbacia foi amostrada

\begin{tabular}{|c|c|c|c|c|c|c|}
\hline & \multirow[b]{2}{*}{ ID } & \multicolumn{2}{|c|}{2003} & \multicolumn{2}{|c|}{2004} & \multirow[b]{2}{*}{$n$} \\
\hline & & chuvosa & seca & chuvosa & seca & \\
\hline \multirow[t]{16}{*}{ pasto } & 1 & & 9 -set & 31-jan & & 2 \\
\hline & 43 & & & 30-jan & 28-jun & 2 \\
\hline & 47 & 24-mar & & & - & 1 \\
\hline & 59 & & 18 -set & 11-mar & & 2 \\
\hline & 60 & & 16 -set & $9-f e v$ & & 2 \\
\hline & 76 & & & 22-jan & 15-jul & 2 \\
\hline & 87 & & 25 -set & 6 e 8 -mar & & 2 \\
\hline & 88 & & 11 -set & 10-fev & & 2 \\
\hline & 140 & & 17 -set & $11-\mathrm{fev}$ & & 2 \\
\hline & 142 & & & 24-mar & $16-7$ & 2 \\
\hline & 188 & & & 23-mar & 23-jul & 2 \\
\hline & 393 & & 23 -set & 2-mar & & 2 \\
\hline & 403 & $27-\mathrm{fev}$ & 19-ago & & & 2 \\
\hline & 413 & $20-\mathrm{fev}$ & 4-set & & & 2 \\
\hline & 414 & $22-\mathrm{fev}$ & 1-ago & & & 2 \\
\hline & 547 & & & 3-fev & 1-jul & 2 \\
\hline \multirow[t]{14}{*}{ ripária } & 2 & 21-mar & 6-ago & & & 2 \\
\hline & 3 & $3-a b r$ & 7-ago & & & 2 \\
\hline & 8 & & & $5-\mathrm{fev}$ & 2-jul & 2 \\
\hline & 15 & & & 21-jan & 25-jun & 2 \\
\hline & 77 & & 24-set & 18-mar & & 2 \\
\hline & 137 & $1-a b r$ & 26-ago & & & 2 \\
\hline & 139 & & & 4-fev & 22-jul & 2 \\
\hline & 150 & & 27 -set & $18-\mathrm{fev}$ & & 2 \\
\hline & 171 & 12-mar & 30-jul & & & 2 \\
\hline & 308 & 18-mar & & & - & 1 \\
\hline & 315 & $14-\mathrm{fev}$ & 28-ago & & & 2 \\
\hline & 318 & & 8-out & 16-mar & & 2 \\
\hline & 352 & $24-\mathrm{fev}$ & 21-ago & & & 2 \\
\hline & 508 & & 12 -set & 17-mar & & 2 \\
\hline total & - & 25 & 38 & 35 & 20 & 118 \\
\hline inéditos & - & 25 & 17 & 18 & 0 & - \\
\hline
\end{tabular}


Anexo B. Planilhas de Campo

Código: Nome da Localidade: Data:

Nome do Rio:

Nome da Bacia:

Município:

Coordenadas (inicial/final):

Fotos:

Cobertura do solo predominante:

Condição da vegetação ripária:

Largura planície de inundação (aprox.) - 3 valores:

Tipo de canal:

Canal: reto $\square$ sinuoso $\square$ Seqüência de habitats: alternada $\square$ complexa $\square$ ausente $\square$ Gradiente: grande $\square$ médio $\square$ pequeno $\square$

Vegetação Ripária (até 10 medidas, transecção de 30 metros perpendicular ao canal) Categorias: 1 - pastagem, 2 - pasto sujo (até 1,5 m), 3 - capoeira (herbáceo predomina), 4 secundária inicial (arbóreo-arbustivo predomina), 5 - secundária tardia.

\begin{tabular}{|c|c|c|c|}
\hline metro & margem & margem & observações \\
\hline 0 & & & \\
\hline 15 & & & \\
\hline 30 & & & \\
\hline 45 & & & \\
\hline 75 & & & \\
\hline 90 & & & \\
\hline 105 & & & \\
\hline 120 & & & \\
\hline 135 & & & \\
\hline 150 & & & \\
\hline
\end{tabular}

Observações: 
Características de habitat

Folha:

Código: Local:

Data:

\begin{tabular}{|c|c|c|c|c|c|c|c|c|c|c|c|c|c|}
\hline \multirow{2}{*}{ metro } & \multirow{2}{*}{ tipo } & \multirow{2}{*}{ área } & \multicolumn{2}{|c|}{ tronco submerso } & \multicolumn{2}{|c|}{ vegetação pendente } & \multicolumn{2}{|c|}{ pacotes de folhas } & \multicolumn{2}{|c|}{ barranco } & \multirow{2}{*}{$\begin{array}{c}\text { Sombra } \\
\%\end{array}$} & \multirow{2}{*}{$\begin{array}{l}\mathrm{V} \\
\text { média }\end{array}$} & \multirow{2}{*}{$\begin{array}{c}\mathrm{n}^{\mathrm{0}} \\
\text { árvores }\end{array}$} \\
\hline & & & tipo & área & tipo & área & presente & área & presente & abrigo & & & \\
\hline & $\begin{array}{c}\text { C R } \\
\text { P } \\
\text { Log } \\
\text { Jam } \\
\text { Salto }\end{array}$ & & $\begin{array}{c}\text { Tronco } \\
\text { Galhada } \\
\text { LOD }\end{array}$ & & $\begin{array}{ll}\text { Erva } & \text { Grama } \\
\text { Lírio } & \text { Bambu } \\
\text { Raiz } & \text { Outros }\end{array}$ & & $\begin{array}{l}\text { Folhas } \\
\text { Algas } \\
\text { Outros }\end{array}$ & & $\square$ & $\square$ & & & \\
\hline & $\begin{array}{l}\text { C R } \\
\text { P } \\
\text { Log } \\
\text { Jam } \\
\text { Salto }\end{array}$ & & $\begin{array}{c}\text { Tronco } \\
\text { Galhada } \\
\text { LOD }\end{array}$ & & $\begin{array}{ll}\text { Erva } & \text { Grama } \\
\text { Lírio } & \text { Bambu } \\
\text { Raiz } & \text { Outros }\end{array}$ & & $\begin{array}{l}\text { Folhas } \\
\text { Algas } \\
\text { Outros }\end{array}$ & & $\square$ & $\square$ & & & \\
\hline & $\begin{array}{l}\text { C R } \\
\text { P } \\
\text { Log } \\
\text { Jam } \\
\text { Salto }\end{array}$ & & $\begin{array}{c}\text { Tronco } \\
\text { Galhada } \\
\text { LOD }\end{array}$ & & $\begin{array}{ll}\text { Erva } & \text { Grama } \\
\text { Lírio } & \text { Bambu } \\
\text { Raiz } & \text { Outros } \\
\end{array}$ & & $\begin{array}{l}\text { Folhas } \\
\text { Algas } \\
\text { Outros }\end{array}$ & & $\square$ & $\square$ & & & \\
\hline & $\begin{array}{l}\text { C R } \\
\text { P } \\
\text { Log } \\
\text { Jam } \\
\text { Salto }\end{array}$ & & $\begin{array}{c}\text { Tronco } \\
\text { Galhada } \\
\text { LOD }\end{array}$ & & $\begin{array}{ll}\text { Erva } & \text { Grama } \\
\text { Lírio } & \text { Bambu } \\
\text { Raiz } & \text { Outros }\end{array}$ & & $\begin{array}{l}\text { Folhas } \\
\text { Algas } \\
\text { Outros }\end{array}$ & & $\square$ & $\square$ & & & \\
\hline & $\begin{array}{c}\text { C R } \\
\text { P } \\
\text { Log } \\
\text { Jam } \\
\text { Salto }\end{array}$ & & $\begin{array}{c}\text { Tronco } \\
\text { Galhada } \\
\text { LOD }\end{array}$ & & $\begin{array}{ll}\text { Erva } & \text { Grama } \\
\text { Lírio } & \text { Bambu } \\
\text { Raiz } & \text { Outros } \\
\end{array}$ & & $\begin{array}{l}\text { Folhas } \\
\text { Algas } \\
\text { Outros }\end{array}$ & & $\square$ & $\square$ & & & \\
\hline
\end{tabular}


Métricas do canal

Folha:

Código:

Local:

Data:

Intervalo nas medidas transversais:

metros. Intervalo entre profundidades:

$\mathrm{cm}$

\begin{tabular}{|c|c|c|c|c|c|c|c|c|c|c|c|c|c|c|c|c|c|c|c|c|c|c|}
\hline \multirow{2}{*}{$\mathrm{n}^{\circ}$} & \multirow{2}{*}{$\begin{array}{c}\text { largu } \\
\text { ra }\end{array}$} & \multicolumn{4}{|c|}{1} & \multicolumn{4}{|c|}{2} & \multicolumn{4}{|c|}{3} & \multicolumn{4}{|c|}{4} & \multicolumn{4}{|c|}{5} & \multirow{2}{*}{$\begin{array}{c}\text { obser } \\
\text { vaçõe } \\
\text { s }\end{array}$} \\
\hline & & $P$ & $S$ & V & $F$ & $P$ & $\mathrm{~s}$ & $\mathrm{~V}$ & $F$ & $\mathrm{P}$ & $S$ & V & $F$ & $P$ & $S$ & V & $F$ & $P$ & $\mathrm{~s}$ & V & $F$ & \\
\hline 1 & & & & & & & & & & & & & & & & & & & & & & \\
\hline 2 & & & & & & & & & & & & & & & & & & & & & & \\
\hline 3 & & & & & & & & & & & & & & & & & & & & & & \\
\hline 4 & & & & & & & & & & & & & & & & & & & & & & \\
\hline 5 & & & & & & & & & & & & & & & & & & & & & & \\
\hline 6 & & & & & & & & & & & & & & & & & & & & & & \\
\hline 7 & & & & & & & & & & & & & & & & & & & & & & \\
\hline 8 & & & & & & & & & & & & & & & & & & & & & & \\
\hline 9 & & & & & & & & & & & & & & & & & & & & & & \\
\hline 10 & & & & & & & & & & & & & & & & & & & & & & \\
\hline 11 & & & & & & & & & & & & & & & & & & & & & & \\
\hline 12 & & & & & & & & & & & & & & & & & & & & & & \\
\hline 13 & & & & & & & & & & & & & & & & & & & & & & \\
\hline 14 & & & & & & & & & & & & & & & & & & & & & & \\
\hline 15 & & & & & & & & & & & & & & & & & & & & & & \\
\hline 16 & & & & & & & & & & & & & & & & & & & & & & \\
\hline 17 & & & & & & & & & & & & & & & & & & & & & & \\
\hline 18 & & & & & & & & & & & & & & & & & & & & & & \\
\hline 19 & & & & & & & & & & & & & & & & & & & & & & \\
\hline 20 & & & & & & & & & & & & & & & & & & & & & & \\
\hline 21 & & & & & & & & & & & & & & & & & & & & & & \\
\hline 22 & & & & & & & & & & & & & & & & & & & & & & \\
\hline 23 & & & & & & & & & & & & & & & & & & & & & & \\
\hline 24 & & & & & & & & & & & & & & & & & & & & & & \\
\hline 25 & & & & & & & & & & & & & & & & & & & & & & \\
\hline
\end{tabular}

P - profundidade, S - substrato, V - velocidade, F - fluxo. 1 - rocha matriz, 2 bloco, 3 - matacão, 4 - seixo, 5 - cascalho, 6 - areia, 7 - silte, 8 - mat. vegetal, 9 tronco e 10 - outros 


\section{Parâmetros Físico-Químicos}

Código: Nome da Localidade:

Data:

Altitude (para calibração):

m. Temperatura do ar (12:00):

Medidas de Temperatura, Oxigênio Dissolvido (à "meia-água") e Condutividade (superfície). Habitat: poço, 'run' ou corredeira. Profundidade e fluxo estimados.

\begin{tabular}{|c|c|c|c|c|c|c|}
\hline $\begin{array}{c}\text { Medida } \\
\text { número }\end{array}$ & T & OD & Saturação. & Habitat & Velocidade & Prof. \\
\hline 1 & & & & & & \\
\hline 2 & & & & & & \\
\hline 3 & & & & & & \\
\hline 4 & & & & & & \\
\hline 5 & & & & & & \\
\hline
\end{tabular}

Amostragem de intensidade luminosa (lux) Leituras tomadas entre 11:00 e 13:00, da jusante para a montante

\begin{tabular}{|c|c|c|c|}
\hline metro & leitura & metro & leitura \\
\hline 0 & & 80 & \\
\hline 5 & & 85 & \\
\hline 10 & & 90 & \\
\hline 15 & & 95 & \\
\hline 20 & & 100 & \\
\hline 25 & & 105 & \\
\hline 30 & & 110 & \\
\hline 35 & & 115 & \\
\hline 40 & & 120 & \\
\hline 45 & & 125 & \\
\hline 50 & & 130 & \\
\hline 55 & & 135 & \\
\hline 60 & & 140 & \\
\hline 65 & & 145 & \\
\hline 70 & & 150 & \\
\hline 75 & & externa- & \\
\hline
\end{tabular}

Observações: 
Tipo de Substrato: lançamentos de quadrado

Código: Local:

Data:

1 - matriz, 2 - bloco, 3 - matacão, 4 - seixo, 5 - cascalho, 6 - areia, 7 - silte, 8 - mat. vegetal, 9 - tronco e 10 - outros

\begin{tabular}{|c|c|c|c|c|c|c|c|c|c|c|c|c|}
\hline \multirow{2}{*}{$\begin{array}{l}\text { lança- } \\
\text { mento }\end{array}$} & \multirow{2}{*}{ metro $n^{0}$} & \multicolumn{10}{|c|}{ porcentagens das categorias de substrato } & \multirow{2}{*}{ habitat } \\
\hline & & 1 & 2 & 3 & 4 & 5 & 6 & 7 & 8 & 9 & 10 & \\
\hline \multicolumn{13}{|l|}{1} \\
\hline \multicolumn{13}{|l|}{2} \\
\hline \multicolumn{13}{|l|}{3} \\
\hline \multicolumn{13}{|l|}{4} \\
\hline \multicolumn{13}{|l|}{5} \\
\hline \multicolumn{13}{|l|}{6} \\
\hline \multicolumn{13}{|l|}{7} \\
\hline \multicolumn{13}{|l|}{8} \\
\hline \multicolumn{13}{|l|}{9} \\
\hline \multicolumn{13}{|l|}{10} \\
\hline \multicolumn{13}{|l|}{11} \\
\hline \multicolumn{13}{|l|}{12} \\
\hline \multicolumn{13}{|l|}{13} \\
\hline \multicolumn{13}{|l|}{14} \\
\hline \multicolumn{13}{|l|}{15} \\
\hline \multicolumn{13}{|l|}{16} \\
\hline \multicolumn{13}{|l|}{17} \\
\hline \multicolumn{13}{|l|}{18} \\
\hline \multicolumn{13}{|l|}{19} \\
\hline \multicolumn{13}{|l|}{20} \\
\hline \multicolumn{13}{|l|}{21} \\
\hline \multicolumn{13}{|l|}{22} \\
\hline \multicolumn{13}{|l|}{23} \\
\hline 24 & & & & & & & & & & & & \\
\hline 25 & & & & & & & & & & & & \\
\hline 26 & & & & & & & & & & & & \\
\hline 27 & & & & & & & & & & & & \\
\hline 28 & & & & & & & & & & & & \\
\hline 29 & & & & & & & & & & & & \\
\hline 30 & & & & & & & & & & & & \\
\hline
\end{tabular}


Anexo C.1. Características das variáveis descritivas das microbacias, código, nome e explicação, unidade, tipo, método se mensuração, e número de categorias (\# categorias)

\begin{tabular}{|c|c|c|c|c|c|c|}
\hline \# & categoria & código & nome da variável & tipo & $\begin{array}{l}\text { contínua } \\
\text { ou discreta }\end{array}$ & \# categorias \\
\hline 1 & posicionais & sub & sub-bacia a que pertence a microbacia & nominal & - & 6 \\
\hline 2 & e contexto & HS & ordenação de Horton-Strahler & proporcional & discreta & - \\
\hline 3 & & SH & ordenação de Shreve & proporcional & discreta & - \\
\hline 4 & & DL & ligação-jusante & proporcional & discreta & - \\
\hline 5 & & $\mathrm{DE}$ & diferença de elevação & categórica & discreta & - \\
\hline 6 & & DQ & distância a um rio de ordem maior & proporcional & contínua & - \\
\hline 7 & & EL & elevação sobre o nível do mar & proporcional & contínua & - \\
\hline 8 & microbacia & AR & área da microbacia & proporcional & contínua & - \\
\hline 9 & & EM & elevação média & proporcional & contínua & - \\
\hline 10 & & DG & declividade geral & proporcional & contínua & - \\
\hline 11 & & $\mathrm{CI}$ & índice de circularidade & proporcional & contínua & - \\
\hline 12 & & $\mathrm{DD}$ & densidade de drenagem & proporcional & contínua & - \\
\hline 13 & & OR & orientação da microbacia & nominal & contínua & 8 \\
\hline 14 & uso na & $\mathrm{CD}$ & cobertura dominante & nominal & discreta & 10 \\
\hline 15 & microbacia & $\mathrm{CP}$ & porcentagem da cobertura dominante & proporcional & contínua & - \\
\hline 16 & & DC & índice de dominância de cobertura & proporcional & contínua & - \\
\hline 17 & & $\mathrm{UC}$ & uso em porcentagem de cana & proporcional & contínua & - \\
\hline 18 & & UP & uso em porcentagem de pasto & proporcional & contínua & - \\
\hline 19 & & UE & uso em porcentagem de plantada & proporcional & contínua & - \\
\hline 20 & & UM & uso em porcentagem de nativa & proporcional & contínua & - \\
\hline 21 & & UF & uso em porcentagem de fruticultura & proporcional & contínua & - \\
\hline 22 & & UA & uso em porcentagem de anual & proporcional & contínua & - \\
\hline 23 & & UI & uso em porcentagem de mineração & proporcional & contínua & - \\
\hline 24 & & UR & $\begin{array}{l}\text { uso em porcentagem de rede } \\
\text { hidrográfica }\end{array}$ & proporcional & contínua & - \\
\hline 25 & & UV & uso em porcentagem de malha & proporcional & contínua & - \\
\hline
\end{tabular}


Anexo C.1. Características das variáveis descritivas das microbacias, código, nome e explicação, unidade, tipo, método se mensuração, e número de categorias (\# categorias)

\begin{tabular}{|c|c|c|c|c|c|c|}
\hline \# & categoria & código & nome da variável & tipo & $\begin{array}{l}\text { contínua } \\
\text { ou discreta }\end{array}$ & \# categorias \\
\hline 26 & & UU & uso em porcentagem de urbana & proporcional & contínua & - \\
\hline 27 & & DB & cobertura vegetal dominante buffer 30 & proporcional & contínua & - \\
\hline 28 & & AJ & área de mata à jusante e à montante & proporcional & contínua & - \\
\hline 29 & & $\mathrm{AM}$ & área de mata da sub-bacia & proporcional & contínua & - \\
\hline 29 & geológica & ER & embasamento rochoso & nominal & discreta & 11 \\
\hline 30 & & TS & tipo de solo & nominal & discreta & 41 \\
\hline 30 & química e & AT & alcalinidade total & proporcional & contínua & - \\
\hline 31 & física da & $\mathrm{NN}$ & N-NH3 & proporcional & contínua & - \\
\hline 32 & água & NI & nitrato & proporcional & contínua & - \\
\hline 33 & & PT & fósforo total & proporcional & contínua & - \\
\hline 34 & & KA & potássio total & proporcional & contínua & - \\
\hline 35 & & $\mathrm{CA}$ & cálcio total & proporcional & contínua & - \\
\hline 36 & & MG & magnésio total & proporcional & contínua & - \\
\hline 37 & & SE & sedimentos em suspensão totais & proporcional & contínua & - \\
\hline 38 & & AA & acidez total & proporcional & contínua & - \\
\hline 39 & & DU & dureza & proporcional & contínua & - \\
\hline 40 & & $\mathrm{CO}$ & gás carbônico & proporcional & contínua & - \\
\hline 41 & & $\mathrm{CR}$ & cor aparente & proporcional & contínua & - \\
\hline 42 & & $\mathrm{TU}$ & turbidez & proporcional & contínua & - \\
\hline 43 & & $\mathrm{CN}$ & condutividade & proporcional & contínua & - \\
\hline 44 & & $\mathrm{pH}$ & potencial hidrogeniônico & proporcional & contínua & - \\
\hline 45 & & OD & oxigênio dissolvido & proporcional & contínua & - \\
\hline 46 & & SA & saturação de oxigênio & proporcional & contínua & - \\
\hline 47 & & TG & temperatura em graus & intervalar & contínua & - \\
\hline
\end{tabular}


Anexo C.1. Características das variáveis descritivas das microbacias, código, nome e explicação, unidade, tipo, método se mensuração, e número de categorias (\# categorias)

\begin{tabular}{|c|c|c|c|c|c|c|}
\hline \# & categoria & código & nome da variável & tipo & $\begin{array}{l}\text { contínua } \\
\text { ou discreta }\end{array}$ & \# categorias \\
\hline 48 & & LP & largura da planície de inundação & proporcional & contínua & - \\
\hline 49 & & DR & declividade do trecho de 150 metros & proporcional & contínua & - \\
\hline 50 & & $\mathrm{AB}$ & altura média de barrancas & proporcional & contínua & - \\
\hline 51 & & $\mathrm{CV}$ & $\begin{array}{l}\text { cobertura vegetal estimada no buffer } \\
30\end{array}$ & proporcional & contínua & - \\
\hline 52 & & AP & número de árvores pendentes & proporcional & discreta & - \\
\hline 53 & & $\mathrm{SO}$ & sombreamento de canal por unidade & proporcional & contínua & - \\
\hline 54 & & IS & insolação & proporcional & discreta & - \\
\hline 55 & $\begin{array}{l}\text { métricas } \\
\text { de }\end{array}$ & NU & $\begin{array}{l}\text { número de unidades de habitat } \\
(\mathrm{P}, \mathrm{R}, \mathrm{C})\end{array}$ & proporcional & discreta & - \\
\hline 56 & canal & $\mathrm{PC}$ & $\begin{array}{l}\text { relação poço/corredeira } \\
\text { (unidade/unidade) }\end{array}$ & proporcional & contínua & - \\
\hline 57 & & $\mathrm{RP}$ & relação poço/corredeira (área/área) & proporcional & contínua & - \\
\hline 58 & & QT & área projetada de troncos & proporcional & contínua & - \\
\hline 59 & & VE & área de vegetação pendente & proporcional & contínua & - \\
\hline 60 & & $\mathrm{PF}$ & área de pacote de materiais orgânicos & proporcional & contínua & - \\
\hline 61 & & UB & unidades com abrigos de barranco & proporcional & discreta & - \\
\hline 62 & & $\mathrm{VM}$ & $\begin{array}{l}\text { velocidade média estimada, por } \\
\text { unidade }\end{array}$ & categórica & discreta & 5 \\
\hline 63 & & LM & largura média de canal & proporcional & contínua & - \\
\hline 64 & & PM & profundidade média do canal & proporcional & contínua & - \\
\hline 65 & & VP & variância da profundidade de canal & proporcional & contínua & - \\
\hline 66 & & $\mathrm{AC}$ & área do canal & proporcional & contínua & - \\
\hline 67 & & $\mathrm{VC}$ & volume do canal & proporcional & contínua & - \\
\hline 68 & & DS & índice de diversidade de substrato & proporcional & contínua & - \\
\hline 69 & & MS & moda de substrato & nominal & discreta & 10 \\
\hline 70 & & $\mathrm{PA}$ & porcentagem de areia & proporcional & contínua & - \\
\hline 71 & & $\mathrm{OV}$ & moda de velocidade & categórica & discreta & 5 \\
\hline 72 & & MV & média de velocidade & proporcional & contínua & - \\
\hline 73 & & VV & variância da velocidade & proporcional & contínua & - \\
\hline 74 & & PU & proporção de fluxos diferentes de 0 & proporcional & discreta & - \\
\hline
\end{tabular}


Anexo C.2. Chaves para as categorias das variáveis nominais e ordinais listadas nos Anexos C1

\begin{tabular}{|c|c|c|}
\hline Variável & Código & Explicação \\
\hline \multirow[t]{6}{*}{ sub } & $\mathrm{ac}$ & Alto Corumbataí \\
\hline & $\mathrm{rc}$ & Ribeirão Claro \\
\hline & ca & Rio da Cabeça \\
\hline & $\mathrm{pc}$ & Passa-Cinco \\
\hline & $\mathrm{mc}$ & Médio Corumbataí \\
\hline & $\mathrm{bc}$ & Baixo Corumbataí \\
\hline \multirow[t]{8}{*}{ OR } & 1 & norte \\
\hline & 2 & nordeste \\
\hline & 3 & leste \\
\hline & 4 & sudeste \\
\hline & 5 & sul \\
\hline & 6 & sudoeste \\
\hline & 7 & oeste \\
\hline & 8 & noroeste \\
\hline \multirow[t]{10}{*}{ CD e DB } & 1 & cana \\
\hline & 2 & pasto \\
\hline & 3 & eucalipto \\
\hline & 4 & matas nativas \\
\hline & 5 & fruticultura \\
\hline & 6 & cultura anual \\
\hline & 7 & mineração \\
\hline & 8 & rede hidrográfica \\
\hline & 9 & malha viária \\
\hline & 10 & área urbana \\
\hline \multirow[t]{3}{*}{ LP } & 1 & fortemente confinado: largura média da planície $<2$ x largura média do canal \\
\hline & 2 & confinado: largura da planície $=2-4$ vezes largura média do canal \\
\hline & 3 & não confinado: largura da planície $>4$ vezes largura média do canal \\
\hline \multirow[t]{5}{*}{$\mathrm{CV}$} & 1 & pasto limpo, manejado \\
\hline & 2 & pasto sujo, não manejado \\
\hline & 3 & capoeira \\
\hline & 4 & secundária inicial \\
\hline & 5 & secundária tardia \\
\hline
\end{tabular}


Anexo C.2. Chaves para as categorias das variáveis nominais e ordinais listadas nos Anexos C1

\begin{tabular}{|c|c|c|}
\hline Variável & Código & Explicação \\
\hline \multirow{10}{*}{ MS } & 1 & rocha-matriz \\
\hline & 2 & bloco \\
\hline & 3 & matacão \\
\hline & 4 & seixo \\
\hline & 5 & cascalho \\
\hline & 6 & areia \\
\hline & 7 & silte \\
\hline & 8 & matéria orgânica \\
\hline & 9 & troncos \\
\hline & 10 & outros \\
\hline \multirow[t]{5}{*}{ OV } & 0 & água com movimento imperceptível, estagnada \\
\hline & 1 & água com movimento perceptível, porém sem alterações na superfície \\
\hline & 2 & superfície da água alterada, mas pouca ondulação, menor que $0,5 \mathrm{~cm}$ \\
\hline & 3 & superfície da água bastante alterada, maior que $0,5 \mathrm{~cm}$ \\
\hline & 4 & água revolta, branca, com bolhas de ar, mesmo fora de saltos \\
\hline \multirow[t]{11}{*}{ ER } & 1 & Formação Botucatu \\
\hline & 2 & Formação Serra-Geral \\
\hline & 3 & Formação Pirambóia \\
\hline & 4 & Formação Corumbataí \\
\hline & 5 & Formação Itaqueri \\
\hline & 6 & Formação Rio Claro \\
\hline & 7 & Formação Irati \\
\hline & 8 & Formação Tatuí \\
\hline & 9 & Grupo Itararé \\
\hline & 10 & Coberturas não diferenciadas \\
\hline & 11 & Depósitos Aluvionais \\
\hline
\end{tabular}

Obs: Não foi possível obter, até a data de conclusão deste trabalho, as codificação para as categorias de tipos de do solo, variável TS 
Anexo D.1. Valores (ou estados) mensurados das 60 microbacias estudadas. No presente anexo (D.1), tratam-se de variáveis que não se alteram entre as estações pois foram calculadas a partir de uma mesma base de dados cartográficos

\begin{tabular}{|c|c|c|c|c|c|c|c|c|c|c|c|c|c|}
\hline ID & sub & AR & $\mathrm{HS}$ & SH & $\mathrm{DL}$ & $\mathrm{DE}$ & DQ & EL & EM & DG & DD & CI & OR \\
\hline 1 & $\mathrm{ac}$ & 458,12 & 3 & 8 & 9 & 111 & 4850 & 760 & 885,64 & 8,89 & 1,80 & 0,71 & 5 \\
\hline 2 & $\mathrm{ac}$ & 367,24 & 2 & 2 & 12 & 111 & 5350 & 760 & 813,49 & 3,04 & 0,68 & 0,78 & 5 \\
\hline 3 & $\mathrm{ac}$ & 366,00 & 3 & 6 & 9 & 62 & 2350 & 722 & 883,47 & 10,83 & 2,04 & 0,48 & 5 \\
\hline 8 & $\mathrm{ac}$ & 810,96 & 3 & 8 & 10 & 20 & 2700 & 720 & 904,52 & 6,36 & 1,62 & 0,59 & 5 \\
\hline 15 & $\mathrm{ac}$ & 257,56 & 2 & 3 & 15 & 51 & 1700 & 700 & 797,71 & 11,28 & 1,65 & 0,42 & 5 \\
\hline 20 & $\mathrm{ac}$ & 517,36 & 3 & 6 & 9 & 60 & 1250 & 760 & 874,72 & 6,16 & 1,43 & 0,65 & 5 \\
\hline 43 & ac & 613,84 & 3 & 11 & 26 & 20 & 650 & 660 & 728,07 & 3,32 & 2,30 & 0,52 & 7 \\
\hline 44 & $\mathrm{ac}$ & 202,28 & 2 & 4 & 8 & 52 & 750 & 692 & 869,10 & 15,86 & 2,00 & 0,66 & 5 \\
\hline 47 & $\mathrm{ac}$ & 278,16 & 2 & 6 & 22 & 0 & 50 & 640 & 769,68 & 9,43 & 2,63 & 0,29 & 5 \\
\hline 59 & $\mathrm{ac}$ & 308,84 & 2 & 8 & 9 & 20 & 2550 & 620 & 687,79 & 5,71 & 1,95 & 0,52 & 6 \\
\hline 60 & $\mathrm{ac}$ & 196,08 & 2 & 6 & 204 & 0 & 150 & 600 & 642,75 & 9,86 & 2,55 & 0,46 & 2 \\
\hline 75 & $\mathrm{rc}$ & 592,16 & 3 & 8 & 11 & 22 & 2800 & 662 & 717,52 & 3,08 & 1,50 & 0,58 & 5 \\
\hline 76 & $\mathrm{rc}$ & 271,32 & 2 & 7 & 9 & 20 & 1750 & 660 & 710,75 & 4,19 & 2,10 & 0,68 & 7 \\
\hline 77 & $\mathrm{ca}$ & 217,48 & 2 & 3 & 13 & 20 & 3400 & 640 & 724,92 & 8,12 & 1,48 & 0,41 & 3 \\
\hline 83 & $\mathrm{ca}$ & 522,52 & 2 & 8 & 11 & 0 & 1650 & 620 & 770,65 & 6,69 & 1,19 & 0,51 & 4 \\
\hline 85 & $\mathrm{ca}$ & 701,80 & 3 & 10 & 14 & 29 & 750 & 669 & 815,47 & 5,18 & 0,81 & 0,74 & 4 \\
\hline 87 & $\mathrm{ac}$ & 533,72 & 3 & 10 & 15 & 20 & 3000 & 600 & 667,26 & 3,06 & 1,72 & 0,50 & 2 \\
\hline 88 & $\mathrm{mc}$ & 221,40 & 3 & 7 & 29 & 0 & 150 & 600 & 628,54 & 2,62 & 2,24 & 0,39 & 4 \\
\hline 120 & $\mathrm{ca}$ & 629,60 & 3 & 8 & 51 & 11 & 600 & 631 & 780,85 & 6,30 & 1,08 & 0,64 & 5 \\
\hline 137 & $\mathrm{ca}$ & 415,16 & 3 & 10 & 44 & 13 & 350 & 620 & 673,90 & 5,32 & 2,04 & 0,38 & 4 \\
\hline 139 & $\mathrm{mc}$ & 113,20 & 2 & 3 & 4 & 20 & 2750 & 620 & 671,26 & 5,52 & 1,82 & 0,53 & 1 \\
\hline 140 & $\mathrm{mc}$ & 285,04 & 2 & 6 & 35 & 0 & 450 & 580 & 627,24 & 4,02 & 1,84 & 0,35 & 2 \\
\hline 142 & $\mathrm{ca}$ & 258,56 & 2 & 3 & 47 & 0 & 200 & 620 & 695,49 & 8,27 & 1,28 & 0,58 & 5 \\
\hline 150 & $\mathrm{mc}$ & 435,76 & 3 & 9 & 14 & 33 & 6200 & 613 & 671,29 & 2,85 & 1,80 & 0,40 & 5 \\
\hline 171 & $\mathrm{ca}$ & 537,04 & 2 & 9 & 12 & 0 & 1100 & 660 & 723,01 & 7,99 & 1,30 & 0,39 & 4 \\
\hline 173 & $\mathrm{pc}$ & 254,68 & 2 & 4 & 5 & 40 & 700 & 680 & 728,76 & 3,43 & 0,85 & 0,72 & 3 \\
\hline 174 & $\mathrm{rc}$ & 423,92 & 2 & 4 & 6 & 20 & 1500 & 620 & 672,22 & 5,28 & 1,49 & 0,70 & 6 \\
\hline 188 & $\mathrm{ca}$ & 228,88 & 3 & 8 & 9 & 40 & 2100 & 640 & 664,98 & 3,69 & 2,42 & 0,36 & 2 \\
\hline 199 & $\mathrm{rc}$ & 214,92 & 2 & 2 & 139 & 0 & 750 & 600 & 675,40 & 5,64 & 0,95 & 0,83 & 7 \\
\hline 200 & $\mathrm{pc}$ & 205,20 & 3 & 14 & 19 & 15 & 300 & 655 & 688,72 & 4,01 & 3,21 & 0,39 & 5 \\
\hline 257 & $\mathrm{rc}$ & 256,52 & 1 & 1 & 141 & 0 & 500 & 600 & 655,10 & 7,71 & 0,50 & 0,58 & 6 \\
\hline 308 & $\mathrm{pc}$ & 254,88 & 3 & 5 & 166 & 0 & 50 & 600 & 731,46 & 15,27 & 1,90 & 0,42 & 6 \\
\hline 315 & $\mathrm{pc}$ & 235,16 & 3 & 4 & 174 & 0 & 140 & 600 & 734,07 & 13,36 & 1,61 & 0,45 & 6 \\
\hline 318 & $\mathrm{pc}$ & 110,08 & 2 & 6 & 7 & 1 & 400 & 601 & 660,98 & 6,29 & 3,62 & 0,60 & 4 \\
\hline 322 & $\mathrm{rc}$ & 125,48 & 1 & 1 & 3 & 21 & 1300 & 601 & 641,74 & 4,40 & 1,03 & 0,71 & 1 \\
\hline 323 & $\mathrm{pc}$ & 198,68 & 1 & 1 & 96 & 28 & 600 & 660 & 752,03 & 15,59 & 0,87 & 0,38 & 1 \\
\hline 352 & $\mathrm{pc}$ & 385,08 & 2 & 3 & 4 & 20 & 450 & 620 & 744,34 & 10,40 & 1,08 & 0,31 & 2 \\
\hline 393 & $\mathrm{rc}$ & 450,44 & 3 & 6 & 7 & 13 & 1200 & 633 & 678,40 & 4,14 & 1,86 & 0,64 & 3 \\
\hline 403 & $\mathrm{pc}$ & 346,72 & 3 & 6 & 8 & 11 & 550 & 751 & 896,08 & 5,92 & 1,98 & 0,70 & 4 \\
\hline 409 & $\mathrm{pc}$ & 193,84 & 2 & 2 & 3 & 60 & 5400 & 620 & 703,77 & 17,18 & 1,22 & 0,50 & 2 \\
\hline 413 & $\mathrm{pc}$ & 631,52 & 2 & 4 & 215 & 1 & 450 & 584 & 688,28 & 8,94 & 1,36 & 0,35 & 1 \\
\hline 414 & $\mathrm{pc}$ & 603,80 & 3 & 6 & 8 & 83 & 3850 & 703 & 923,02 & 7,69 & 1,33 & 0,43 & 1 \\
\hline 485 & $\mathrm{pc}$ & 1042,96 & 3 & 12 & 14 & 101 & 4750 & 721 & 943,54 & 6,42 & 1,63 & 0,59 & 2 \\
\hline 508 & $\mathrm{bc}$ & 294,76 & 2 & 6 & 8 & 20 & 1150 & 600 & 702,95 & 11,69 & 1,75 & 0,27 & 4 \\
\hline 531 & $b c$ & 249,92 & 2 & 3 & 9 & 40 & 7350 & 560 & 602,64 & 3,39 & 1,18 & 0,43 & 2 \\
\hline 547 & $\mathrm{bc}$ & 631,08 & 3 & 11 & 18 & 0 & 250 & 580 & 709,91 & 9,24 & 2,14 & 0,43 & 4 \\
\hline 553 & $\mathrm{mc}$ & 81,04 & 2 & 2 & 5 & 74 & 6900 & 589 & 599,48 & 1,80 & 1,35 & 0,79 & 5 \\
\hline 561 & $\mathrm{rc}$ & 157,72 & 2 & 2 & 4 & 60 & 5300 & 620 & 657,96 & 4,49 & 1,52 & 0,68 & 7 \\
\hline 572 & $\mathrm{rc}$ & 172,68 & 1 & 1 & 4 & 100 & 6850 & 660 & 741,68 & 6,49 & 0,86 & 0,75 & 8 \\
\hline
\end{tabular}


Anexo D.1. Valores (ou estados) mensurados das 60 microbacias estudadas. No presente anexo (D.1), tratam-se de variáveis que não se alteram entre as estações pois foram calculadas a partir de uma mesma base de dados cartográficos

\begin{tabular}{cccccccccccccc}
\hline ID & sub & AR & HS & SH & DL & DE & DQ & EL & EM & DG & DD & CI & OR \\
\hline 580 & rc & 389,32 & 1 & 1 & 3 & 67 & 6300 & 627 & 729,42 & 3,80 & 0,95 & 0,40 & 8 \\
608 & mc & 496,92 & 2 & 3 & 22 & 30 & 2950 & 530 & 596,03 & 2,58 & 0,92 & 0,50 & 8 \\
615 & bc & 233,72 & 2 & 3 & 4 & 0 & 400 & 500 & 573,24 & 5,27 & 1,63 & 0,72 & 3 \\
616 & bc & 520,84 & 3 & 7 & 41 & 0 & 200 & 540 & 573,03 & 2,08 & 1,27 & 0,61 & 8 \\
619 & $\mathrm{bc}$ & 243,52 & 1 & 1 & 2 & 29 & 2200 & 540 & 574,40 & 1,60 & 0,99 & 0,65 & 2 \\
620 & $\mathrm{bc}$ & 389,08 & 2 & 3 & 4 & 0 & 350 & 500 & 576,65 & 4,04 & 1,54 & 0,48 & 7 \\
632 & $\mathrm{bc}$ & 352,80 & 2 & 2 & 5 & 40 & 3950 & 520 & 553,66 & 1,85 & 1,22 & 0,45 & 3 \\
634 & $\mathrm{bc}$ & 495,52 & 2 & 5 & 8 & 29 & 3100 & 520 & 596,68 & 3,21 & 1,32 & 0,62 & 6 \\
635 & $\mathrm{bc}$ & 346,40 & 3 & 24 & 96 & 0 & 600 & 500 & 542,48 & 2,19 & 4,17 & 0,48 & 3 \\
648 & $\mathrm{bc}$ & 493,88 & 2 & 4 & 5 & 20 & 2250 & 500 & 558,76 & 3,24 & 1,03 & 0,46 & 6 \\
652 & $\mathrm{bc}$ & 220,16 & 2 & 6 & 1945 & 3 & 400 & 483 & 550,11 & 3,46 & 2,32 & 0,43 & 6 \\
\hline
\end{tabular}


Anexo D.2. Valores (ou estados) mensurados das 60 microbacias estudadas, com as variáveis do uso e cobertura do solo.

\begin{tabular}{|c|c|c|c|c|c|c|c|c|c|c|c|c|c|c|c|c|c|c|}
\hline ID & CD & $\mathrm{CP}$ & DC & UC & UP & UE & UM & UF & UA & UI & UR & UV & UU & DB & AJ & $\mathrm{AM}$ & ER & TS \\
\hline 1 & 2 & 63,2 & 0,51 & 0,0 & 63,2 & 0,0 & 33,6 & 0,0 & 0,0 & 0,0 & 3,1 & 0,0 & 0,0 & 2 & 5,52 & 26,72 & 10 & 49 \\
\hline 2 & 4 & 49,8 & 0,40 & 0,0 & 49,8 & 0,0 & 10,4 & 37,7 & 0,0 & 0,0 & 1,2 & 0,9 & 0,0 & 3 & 4,04 & 26,72 & 10 & 7 \\
\hline 3 & 4 & 59,4 & 0,48 & 0,0 & 59,4 & 0,4 & 35,5 & 0,0 & 0,0 & 0,0 & 3,7 & 1,1 & 0,0 & 3 & 3,80 & 26,72 & 2 & 49 \\
\hline 8 & 4 & 52,6 & 0,38 & 0,0 & 52,6 & 15,9 & 27,9 & 0,0 & 0,0 & 0,0 & 2,8 & 0,7 & 0,0 & 3 & 4,04 & 26,72 & 2 & 16 \\
\hline 15 & 4 & 46,5 & 0,41 & 0,0 & 46,5 & 5,7 & 43,7 & 0,0 & 0,0 & 0,0 & 2,9 & 0,9 & 0,3 & 3 & 4,28 & 26,72 & 10 & 23 \\
\hline 20 & 3 & 56,5 & 0,48 & 0,0 & 40,2 & 0,0 & 56,5 & 0,0 & 0,0 & 0,0 & 2,5 & 0,8 & 0,0 & 3 & 6,96 & 26,72 & 1 & 37 \\
\hline 43 & 2 & 53,5 & 0,39 & 0,0 & 53,5 & 14,4 & 27,8 & 0,0 & 0,0 & 0,0 & 4,0 & 0,4 & 0,0 & 2 & 5,52 & 26,72 & 10 & 12 \\
\hline 44 & 3 & 64,2 & 0,50 & 0,0 & 29,0 & 2,9 & 64,2 & 0,0 & 0,0 & 0,0 & 3,4 & 0,6 & 0,0 & 3 & 5,00 & 26,72 & 1 & 48 \\
\hline 47 & 2 & 44,6 & 0,32 & 31,9 & 44,6 & 5,3 & 13,7 & 0,0 & 0,0 & 0,0 & 4,5 & 0,0 & 0,0 & 2 & 0,32 & 26,72 & 4 & 12 \\
\hline 59 & 2 & 80,9 & 0,67 & 0,0 & 80,9 & 2,3 & 12,3 & 0,0 & 0,0 & 0,0 & 3,2 & 1,3 & 0,0 & 2 & 0,24 & 26,72 & 3 & 12 \\
\hline 60 & 2 & 90,5 & 0,82 & 0,0 & 90,5 & 0,0 & 1,2 & 2,6 & 0,0 & 0,0 & 4,2 & 1,5 & 0,0 & 2 & 0,00 & 26,72 & 3 & 12 \\
\hline 75 & 1 & 38,1 & 0,26 & 38,1 & 18,5 & 16,2 & 23,7 & 0,0 & 0,0 & 0,0 & 2,5 & 1,0 & 0,0 & 3 & 3,68 & 11,44 & 3 & 23 \\
\hline 76 & 2 & 76,8 & 0,61 & 5,6 & 76,8 & 0,3 & 13,8 & 0,0 & 0,0 & 0,0 & 3,4 & 0,1 & 0,0 & 2 & 1,12 & 11,44 & 3 & 38 \\
\hline 77 & 4 & 49,7 & 0,36 & 20,3 & 49,7 & 0,0 & 27,6 & 0,0 & 0,0 & 0,0 & 2,4 & 0,0 & 0,0 & 3 & 2,76 & 14,29 & 3 & 12 \\
\hline 83 & 1 & 59,3 & 0,42 & 59,3 & 20,1 & 0,5 & 17,8 & 0,0 & 0,0 & 0,0 & 1,9 & 0,4 & 0,0 & 2 & 0,36 & 14,29 & 1 & 7 \\
\hline 85 & 1 & 39,4 & 0,28 & 39,4 & 6,2 & 12,1 & 8,3 & 31,9 & 0,0 & 0,0 & 1,3 & 0,8 & 0,0 & 3 & 7,00 & 14,29 & 1 & 7 \\
\hline 87 & 2 & 75,0 & 0,59 & 3,1 & 75,0 & 4,3 & 14,6 & 0,0 & 0,1 & 0,0 & 2,9 & 0,1 & 0,0 & 2 & 0,16 & 26,72 & 3 & 12 \\
\hline 88 & 2 & 89,2 & 0,80 & 0,0 & 89,2 & 0,0 & 3,8 & 0,0 & 1,4 & 0,0 & 3,4 & 2,2 & 0,0 & 2 & 0,64 & 9,2 & 4 & 12 \\
\hline 120 & 1 & 56,7 & 0,39 & 56,7 & 9,9 & 3,5 & 23,2 & 3,1 & 0,0 & 0,0 & 2,0 & 1,5 & 0,1 & 3 & 2,20 & 14,29 & 1 & 7 \\
\hline 137 & 4 & 62,4 & 0,45 & 9,4 & 62,4 & 0,3 & 23,1 & 0,0 & 0,0 & 0,0 & 3,3 & 1,4 & 0,0 & 3 & 4,96 & 14,29 & 3 & 12 \\
\hline 139 & 4 & 82,4 & 0,70 & 0,0 & 82,4 & 0,0 & 13,4 & 0,0 & 1,5 & 0,0 & 2,2 & 0,5 & 0,0 & 3 & 0,00 & 9,2 & 3 & 12 \\
\hline 140 & 2 & 81,3 & 0,67 & 0,0 & 81,3 & 0,0 & 10,4 & 0,0 & 2,6 & 0,0 & 3,2 & 2,5 & 0,0 & 2 & 1,24 & 9,2 & 4 & 12 \\
\hline 142 & 2 & 66,7 & 0,49 & 13,9 & 66,7 & 1,7 & 15,7 & 0,0 & 0,0 & 0,0 & 2,0 & 0,0 & 0,0 & 2 & 0,00 & 14,29 & 3 & 54 \\
\hline 150 & 4 & 34,5 & 0,28 & 7,7 & 34,5 & 32,3 & 21,9 & 0,0 & 0,0 & 0,0 & 2,8 & 0,8 & 0,0 & 3 & 6,40 & 9,2 & 3 & 12 \\
\hline 171 & 4 & 54,0 & 0,37 & 0,0 & 54,0 & 11,0 & 23,8 & 0,0 & 0,0 & 0,0 & 2,2 & 2,6 & 6,4 & 3 & 4,28 & 14,29 & 1 & 7 \\
\hline 173 & 3 & 66,5 & 0,49 & 0,0 & 8,6 & 66,5 & 20,7 & 0,0 & 0,0 & 0,0 & 0,0 & 4,2 & 0,0 & 3 & 10,2 & 26,62 & 1 & 46 \\
\hline 174 & 1 & 56,7 & 0,40 & 56,7 & 24,0 & 0,1 & 11,6 & 0,0 & 4,8 & 0,0 & 2,5 & 0,3 & 0,0 & 2 & 0,00 & 11,44 & 4 & 47 \\
\hline 188 & 2 & 76,0 & 0,62 & 0,0 & 76,0 & 0,0 & 18,8 & 0,0 & 0,0 & 0,0 & 4,2 & 1,0 & 0,0 & 2 & 0,68 & 14,29 & 3 & 40 \\
\hline 199 & 1 & 45,9 & 0,31 & 45,9 & 12,2 & 0,1 & 25,9 & 0,0 & 14,1 & 0,0 & 1,7 & 0,0 & 0,0 & 3 & 2,36 & 11,44 & 2 & 47 \\
\hline 200 & 3 & 47,5 & 0,42 & 0,0 & 43,5 & 3,0 & 47,5 & 0,0 & 0,0 & 0,0 & 5,3 & 0,6 & 0,0 & 3 & 4,56 & 26,62 & 3 & 7 \\
\hline 257 & 3 & 54,6 & 0,45 & 38,7 & 4,2 & 1,0 & 54,6 & 0,0 & 0,0 & 0,0 & 0,7 & 0,8 & 0,0 & 1 & 2,80 & 11,44 & 2 & 29 \\
\hline 308 & 4 & 59,1 & 0,46 & 0,0 & 59,1 & 4,3 & 33,3 & 0,0 & 0,1 & 0,0 & 3,1 & 0,0 & 0,0 & 3 & 5,40 & 26,62 & 3 & 48 \\
\hline 315 & 4 & 54,9 & 0,40 & 0,0 & 54,9 & 4,6 & 31,1 & 0,0 & 6,1 & 0,0 & 2,8 & 0,5 & 0,0 & 3 & 3,52 & 26,62 & 3 & 40 \\
\hline 318 & 4 & 52,9 & 0,44 & 0,0 & 52,9 & 0,8 & 40,2 & 0,0 & 0,0 & 0,0 & 5,9 & 0,3 & 0,0 & 3 & 13,8 & 26,62 & 3 & 40 \\
\hline 322 & 1 & 89,0 & 0,80 & 89,0 & 6,3 & 0,0 & 0,5 & 0,0 & 0,0 & 0,0 & 1,6 & 2,6 & 0,0 & 2 & 0,00 & 11,44 & 2 & 14 \\
\hline 323 & 3 & 47,8 & 0,41 & 0,0 & 41,4 & 9,2 & 47,8 & 0,0 & 0,0 & 0,0 & 1,5 & 0,1 & 0,0 & 3 & 2,08 & 26,62 & 3 & 46 \\
\hline 352 & 4 & 51,1 & 0,45 & 0,0 & 51,1 & 2,9 & 43,8 & 0,0 & 0,0 & 0,0 & 2,2 & 0,0 & 0,0 & 3 & 2,88 & 26,62 & 3 & 46 \\
\hline 393 & 2 & 65,3 & 0,48 & 16,4 & 65,3 & 0,0 & 15,2 & 0,0 & 0,0 & 0,0 & 3,1 & 0,0 & 0,0 & 2 & 0,48 & 11,44 & 2 & 12 \\
\hline 403 & 2 & 60,4 & 0,41 & 9,3 & 60,4 & 9,9 & 16,4 & 0,0 & 0,0 & 0,0 & 3,4 & 0,6 & 0,0 & 2 & 0,00 & 26,62 & 5 & 9 \\
\hline 409 & 3 & 54,7 & 0,44 & 6,6 & 36,6 & 0,0 & 54,7 & 0,0 & 0,0 & 0,0 & 2,1 & 0,0 & 0,0 & 3 & 4,08 & 26,62 & 3 & 46 \\
\hline 413 & 2 & 62,0 & 0,45 & 17,5 & 62,0 & 0,0 & 18,2 & 0,0 & 0,0 & 0,0 & 2,3 & 0,0 & 0,0 & 2 & 0,04 & 26,62 & 3 & 46 \\
\hline 414 & 2 & 47,5 & 0,32 & 10,6 & 47,5 & 12,1 & 26,9 & 0,0 & 0,0 & 0,0 & 2,3 & 0,7 & 0,0 & 2 & 0,24 & 26,62 & 5 & 37 \\
\hline 485 & 3 & 37,1 & 0,30 & 14,4 & 36,0 & 8,4 & 37,1 & 0,0 & 0,0 & 0,0 & 2,7 & 1,4 & 0,0 & 3 & 6,08 & 26,62 & 5 & 37 \\
\hline 508 & 4 & 43,8 & 0,35 & 16,3 & 43,8 & 0,0 & 36,3 & 0,0 & 0,0 & 0,0 & 2,6 & 1,0 & 0,0 & 3 & 1,92 & 11,74 & 3 & 46 \\
\hline 531 & 1 & 78,2 & 0,64 & 78,2 & 16,3 & 0,0 & 2,3 & 0,0 & 0,0 & 0,0 & 2,1 & 1,1 & 0,0 & 2 & 3,60 & 11,74 & 7 & 41 \\
\hline 547 & 2 & 43,7 & 0,33 & 30,2 & 43,7 & 0,0 & 22,5 & 0,0 & 0,0 & 0,0 & 3,4 & 0,2 & 0,0 & 2 & 2,20 & 11,74 & 3 & 12 \\
\hline 553 & 1 & 66,8 & 0,51 & 66,8 & 24,9 & 0,0 & 6,3 & 0,0 & 0,0 & 0,0 & 2,1 & 0,0 & 0,0 & 2 & 1,84 & 9,2 & 6 & 35 \\
\hline 561 & 1 & 77,4 & 0,62 & 77,4 & 15,3 & 0,0 & 0,3 & 0,0 & 0,0 & 0,0 & 4,1 & 2,9 & 0,0 & 1 & 0,24 & 11,44 & 2 & 29 \\
\hline 572 & 3 & 63,4 & 0,47 & 13,7 & 22,6 & 0,0 & 63,4 & 0,0 & 0,0 & 0,0 & 0,0 & 0,3 & 0,0 & 3 & 3,20 & 11,44 & 3 & 1 \\
\hline
\end{tabular}


Anexo D.2. Valores (ou estados) mensurados das 60 microbacias estudadas, com as variáveis do uso e cobertura do solo.

\begin{tabular}{ccccccccccccccccccc}
\hline ID & CD & CP & DC & UC & UP & UE & UM & UF & UA & UI & UR & UV & UU & DB & AJ & AM & ER & TS \\
\hline 580 & 1 & 78,9 & 0,64 & 78,9 & 13,3 & 0,0 & 6,1 & 0,0 & 0,0 & 0,0 & 1,7 & 0,0 & 0,0 & 2 & 0,00 & 11,44 & 3 & 1 \\
608 & 1 & 70,4 & 0,56 & 70,4 & 25,0 & 0,0 & 1,8 & 0,0 & 0,0 & 0,0 & 1,6 & 1,2 & 0,0 & 2 & 1,00 & 9,2 & 4 & 43 \\
615 & 3 & 43,6 & 0,39 & 43,3 & 9,1 & 0,0 & 43,6 & 0,0 & 0,0 & 0,0 & 2,5 & 1,5 & 0,0 & 3 & 0,00 & 11,74 & 9 & 50 \\
616 & 1 & 57,4 & 0,42 & 57,4 & 29,1 & 0,0 & 1,4 & 0,0 & 0,0 & 0,0 & 2,1 & 2,7 & 7,3 & 2 & 0,04 & 11,74 & 4 & 12 \\
619 & 1 & 65,4 & 0,49 & 65,4 & 24,4 & 0,0 & 0,2 & 0,0 & 0,0 & 0,0 & 1,8 & 2,0 & 6,2 & 2 & 0,00 & 11,74 & 4 & 17 \\
620 & 1 & 45,2 & 0,34 & 45,2 & 27,3 & 0,0 & 24,3 & 0,0 & 0,0 & 0,0 & 2,5 & 0,8 & 0,0 & 3 & 0,00 & 11,74 & 9 & 50 \\
632 & 1 & 61,3 & 0,48 & 61,3 & 32,4 & 0,0 & 2,6 & 0,0 & 0,0 & 0,0 & 2,1 & 1,6 & 0,0 & 2 & 0,00 & 11,74 & 4 & 12 \\
634 & 1 & 42,1 & 0,29 & 42,1 & 24,6 & 8,7 & 21,3 & 0,0 & 0,0 & 0,0 & 2,2 & 1,0 & 0,0 & 3 & 0,08 & 11,74 & 6 & 50 \\
635 & 1 & 64,6 & 0,49 & 64,6 & 26,4 & 0,0 & 1,5 & 0,0 & 0,0 & 0,0 & 7,0 & 0,5 & 0,0 & 1 & 2,60 & 11,74 & 4 & 26 \\
648 & 3 & 51,3 & 0,37 & 22,7 & 22,5 & 0,7 & 51,3 & 0,0 & 0,0 & 0,0 & 1,8 & 1,0 & 0,0 & 3 & 4,72 & 11,74 & 9 & 50 \\
652 & 1 & 43,0 & 0,34 & 43,0 & 35,7 & 0,0 & 15,4 & 0,0 & 0,0 & 0,0 & 3,7 & 2,3 & 0,0 & 2 & 1,52 & 11,74 & 4 & 50 \\
\hline
\end{tabular}

Anexo D.3. Valores (ou estados) mensurados das 60 microbacias estudadas, com as variáveis dos parâmetros químicos e físicos da água nas estações chuvosas

\begin{tabular}{|c|c|c|c|c|c|c|c|c|c|c|c|c|c|c|c|c|c|c|}
\hline ID & AT & NN & NI & PT & KA & CA & MG & SE & $\mathrm{AZ}$ & DU & $\mathrm{CO}$ & CR & TU & $\mathrm{CN}$ & $\mathrm{pH}$ & OD & SA & TG \\
\hline 1 & 11,00 & 0,30 & 1,00 & 0,02 & 0,80 & 2,10 & 1,20 & 14,00 & 2,50 & 10,00 & 1,40 & 60,00 & 12,00 & 0,06 & 7,10 & 7,52 & - & 24,34 \\
\hline 2 & 4,00 & 0,30 & - & 0,02 & 1,00 & 1,00 & 0,40 & 25,00 & 9,40 & 4,10 & 1,30 & 34,00 & 12,00 & 0,06 & 6,70 & 7,94 & - & 21,90 \\
\hline 3 & 10,60 & 0,30 & - & 0,03 & 2,30 & 1,70 & 1,10 & 19,00 & 24,80 & 8,60 & 3,40 & 8,00 & 2,00 & 0,06 & 6,70 & 8,40 & - & 21,01 \\
\hline 8 & 17,80 & 0,20 & 1,50 & 0,04 & 1,90 & 2,20 & 1,20 & 8,00 & 4,50 & 10,60 & 3,60 & 97,00 & 23,00 & 0,06 & 6,90 & 7,87 & 91,24 & 22,64 \\
\hline 15 & 9,60 & 0,40 & 4,20 & 0,10 & 0,90 & 1,80 & 0,80 & 21,30 & 21,80 & 7,80 & 4,90 & 47,00 & 14,00 & 0,06 & 6,50 & 7,53 & - & 20,98 \\
\hline 20 & 12,00 & 0,30 & 0,20 & 0,02 & 1,70 & 1,60 & 1,00 & 16,70 & 27,80 & 7,90 & 9,60 & 80,00 & 63,00 & 0,06 & 6,30 & 6,37 & - & 21,93 \\
\hline 43 & 8,40 & 0,20 & 3,10 & 0,03 & 0,90 & 1,30 & 0,70 & 99,70 & 6,50 & 6,10 & 3,40 & 92,00 & 25,00 & 0,06 & 6,60 & 8,26 & - & 21,70 \\
\hline 44 & 17,00 & 0,40 & - & 0,03 & 1,00 & 3,10 & 1,40 & 9,00 & 16,40 & 13,50 & 1,40 & 52,00 & 14,00 & 0,08 & 7,30 & 8,60 & - & 20,12 \\
\hline 47 & 18,80 & 0,30 & - & 0,06 & 1,50 & 4,10 & 1,90 & 27,00 & 23,80 & 17,90 & 1,50 & 132,0 & 32,00 & 0,07 & 7,30 & 8,16 & - & 22,18 \\
\hline 59 & 19,00 & 0,30 & 2,00 & 0,04 & 2,50 & 3,70 & 1,10 & 8,70 & 8,90 & 14,00 & 3,80 & 92,00 & 18,00 & 0,07 & 6,90 & 7,04 & 85,12 & 25,06 \\
\hline 60 & 30,20 & 0,30 & 0,50 & 0,04 & 3,40 & 8,50 & 1,70 & 19,70 & 8,40 & 28,20 & 3,10 & 198,0 & 38,00 & 0,10 & 7,20 & 8,20 & 94,48 & 21,84 \\
\hline 75 & 9,80 & 0,30 & 1,10 & 0,04 & 1,20 & 2,00 & 0,60 & 16,70 & 6,90 & 7,30 & 3,90 & 126,0 & 50,00 & 0,06 & 6,60 & 8,16 & 96,28 & 23,56 \\
\hline 76 & 60,60 & 0,40 & 4,20 & 0,10 & 2,80 & 16,00 & 5,00 & 29,70 & 14,90 & 60,20 & 1,20 & 56,00 & 11,00 & 0,12 & 7,90 & 8,26 & - & 21,72 \\
\hline 77 & 19,00 & 0,20 & 0,40 & 0,04 & 1,20 & 4,50 & 1,30 & 21,70 & 5,50 & 16,50 & 3,00 & 355,0 & 390,0 & 0,12 & 7,00 & 7,93 & 91,46 & 22,42 \\
\hline 83 & 16,20 & 0,20 & 0,30 & 0,04 & 0,90 & 3,50 & 1,00 & 23,30 & 14,90 & 12,80 & 4,10 & 113,0 & 171,0 & 0,06 & 6,80 & 7,80 & - & 21,80 \\
\hline 85 & 8,00 & 0,10 & 1,70 & 0,06 & 0,50 & 2,00 & 0,80 & 26,70 & 1,50 & 8,10 & 1,60 & 126,0 & 38,00 & 0,05 & 6,90 & 8,39 & 94,12 & 21,00 \\
\hline 87 & 29,80 & 0,30 & 0,60 & 0,08 & 2,20 & 7,40 & 2,20 & 18,70 & 10,90 & 27,70 & 4,80 & 128,0 & 25,00 & 0,10 & 7,00 & 8,35 & 97,58 & 23,16 \\
\hline 88 & 46,00 & 0,20 & 0,90 & 0,10 & 4,40 & 8,80 & 2,70 & 26,00 & 9,90 & 32,90 & 1,50 & 142,0 & 29,00 & 0,10 & 7,70 & 8,37 & 95,80 & 21,80 \\
\hline 120 & 18,00 & 0,30 & 0,60 & 0,02 & 0,70 & 2,80 & 0,90 & 5,30 & 19,90 & 10,50 & 2,90 & 28,00 & 6,00 & 0,05 & 7,00 & 8,07 & - & 21,58 \\
\hline 137 & 16,20 & 0,60 & - & 0,04 & 1,80 & 3,00 & 1,00 & 16,30 & 76,90 & 11,60 & 10,30 & 85,00 & 17,00 & 0,07 & 6,40 & 4,50 & - & 20,79 \\
\hline 139 & 17,80 & 0,30 & 1,40 & 0,09 & 2,30 & 4,30 & 1,20 & 2868,3 & 5,00 & 15,70 & 1,80 & 126,0 & 29,00 & 0,08 & 7,20 & 7,56 & - & 25,62 \\
\hline 140 & 42,00 & 0,10 & 0,60 & 0,04 & 3,70 & 8,70 & 3,30 & 14,00 & 17,40 & 35,50 & 6,70 & 113,0 & 33,00 & 0,11 & 7,00 & 3,27 & 41,66 & 22,36 \\
\hline 142 & 34,80 & 0,30 & 0,50 & 0,03 & 1,40 & 7,40 & 2,70 & 36,00 & 13,90 & 29,40 & 3,50 & 112,0 & 20,00 & 0,08 & 7,20 & 8,65 & 98,04 & 21,36 \\
\hline 150 & 8,60 & 0,20 & 4,40 & 0,04 & 2,10 & 2,50 & 0,80 & 18,70 & 7,40 & 9,60 & 3,50 & 113,0 & 44,00 & 0,07 & 6,60 & 8,54 & 96,58 & 21,36 \\
\hline 171 & 9,40 & 0,30 & - & 0,04 & 1,30 & 1,20 & 0,80 & 130,0 & 7,90 & 6,30 & 3,80 & 40,00 & 17,00 & 0,06 & 6,60 & 7,85 & - & 22,86 \\
\hline 173 & 15,00 & 0,30 & 0,20 & 0,03 & 1,50 & 1,50 & 0,90 & 25,00 & 19,90 & 7,40 & 15,10 & 11,00 & 18,00 & 0,07 & 6,20 & 6,89 & 80,76 & 23,22 \\
\hline 174 & 11,00 & 0,20 & 5,20 & 0,08 & 1,60 & 1,70 & 1,60 & 12,30 & 9,90 & 10,90 & 5,60 & 202,0 & 38,00 & 0,07 & 6,50 & 8,24 & 94,56 & 21,70 \\
\hline 188 & 23,20 & 0,20 & 0,80 & 0,05 & 2,20 & 5,70 & 2,10 & 28,30 & 5,00 & 23,00 & 3,70 & 144,0 & 86,00 & 0,07 & 7,00 & 8,62 & 96,58 & 20,94 \\
\hline 199 & 33,20 & 0,30 & 0,50 & 0,05 & 1,10 & 5,70 & 2,30 & 7,30 & 4,00 & 23,70 & 1,70 & 102,0 & 36,00 & 0,09 & 7,50 & 8,06 & 88,52 & 19,96 \\
\hline 200 & 9,20 & 0,20 & - & 0,04 & 1,00 & 1,30 & 0,80 & 53,00 & 6,00 & 6,60 & 3,70 & 170,0 & 31,00 & 0,05 & 6,60 & 7,06 & - & 25,55 \\
\hline
\end{tabular}


Anexo D.3. Valores (ou estados) mensurados das 60 microbacias estudadas, com as variáveis dos parâmetros químicos e físicos da água nas estações chuvosas

\begin{tabular}{|c|c|c|c|c|c|c|c|c|c|c|c|c|c|c|c|c|c|c|}
\hline ID & AT & $\mathrm{NN}$ & NI & PT & KA & $\mathrm{CA}$ & MG & SE & $\mathrm{AZ}$ & DU & $\mathrm{CO}$ & CR & $\mathrm{TU}$ & $\mathrm{CN}$ & $\mathrm{pH}$ & OD & SA & TG \\
\hline 257 & 15,60 & 0,20 & 0,90 & 0,08 & 0,50 & 2,60 & 1,60 & 23,00 & 6,90 & 12,90 & 4,00 & 151,0 & 30,00 & 0,07 & 6,80 & 8,48 & 95,66 & 21,24 \\
\hline 308 & 9,60 & 0,30 & - & 0,02 & 1,60 & 2,00 & 1,10 & 16,00 & 12,90 & 9,50 & 1,20 & 1,00 & 4,00 & 0,07 & 7,10 & 8,07 & - & 20,71 \\
\hline 315 & 14,40 & 1,10 & - & 0,05 & 2,00 & 2,70 & 1,20 & 30,70 & 5,00 & 11,80 & 0,90 & 100,0 & 23,00 & 0,06 & 7,40 & 7,82 & - & 21,40 \\
\hline 318 & 12,00 & 0,30 & 1,40 & 0,13 & 2,10 & 3,10 & 0,70 & 281,7 & 5,00 & 10,40 & 3,80 & 56,00 & 104,0 & 0,07 & 6,70 & 8,51 & 94,96 & 20,84 \\
\hline 322 & 18,00 & 0,20 & - & 0,05 & 0,60 & 3,90 & 1,60 & 56,00 & 7,90 & 16,40 & 3,60 & 88,00 & 25,00 & 0,07 & 6,90 & 7,77 & - & 21,38 \\
\hline 323 & 32,00 & 0,10 & - & 0,03 & 1,60 & 6,10 & 3,60 & 20,70 & 8,40 & 30,00 & 1,30 & 191,0 & 42,00 & 0,08 & 7,60 & 8,03 & - & 22,55 \\
\hline 352 & 19,20 & 0,10 & - & 0,05 & 1,50 & 3,10 & 1,70 & 35,30 & 11,90 & 14,60 & 1,20 & 163,0 & 36,00 & 0,06 & 7,40 & 7,38 & - & 26,34 \\
\hline 393 & 55,00 & 0,30 & 1,20 & 0,05 & 2,10 & 8,90 & 4,10 & 26,30 & 24,80 & 39,00 & 8,80 & 47,00 & 36,00 & 0,11 & 7,00 & 6,89 & 77,54 & 21,30 \\
\hline 403 & 14,20 & 0,20 & - & 0,03 & 1,40 & 2,20 & 1,20 & 31,30 & 10,40 & 10,50 & 1,80 & 194,0 & 53,00 & 0,05 & 7,10 & 7,70 & - & 25,40 \\
\hline 409 & 37,00 & 0,30 & 1,00 & 0,13 & 3,50 & 7,20 & 4,00 & 1188 & 6,00 & 34,30 & 4,70 & 186,0 & 396,0 & 0,09 & 7,10 & 8,27 & 94,94 & 22,10 \\
\hline 413 & 18,20 & 0,60 & - & 0,03 & 0,70 & 3,20 & 1,70 & 16,30 & 7,40 & 14,90 & 7,80 & 77,00 & 15,00 & 0,07 & 6,60 & 7,19 & - & 23,60 \\
\hline 414 & 17,40 & 1,00 & - & 0,07 & 0,40 & 3,20 & 1,30 & 27,70 & 15,40 & 13,30 & 1,10 & 87,00 & 21,00 & 0,06 & 7,40 & 7,80 & - & 24,39 \\
\hline 485 & 14,40 & 0,90 & - & 0,05 & 0,50 & 2,60 & 0,90 & 9,70 & 5,50 & 10,20 & 1,00 & 44,00 & 8,00 & 0,06 & 7,40 & 7,87 & - & 23,37 \\
\hline 508 & 22,60 & 0,30 & 2,10 & 0,20 & 2,70 & 6,20 & 2,70 & 629,7 & 9,90 & 26,50 & 3,60 & 355,0 & 314,0 & 0,08 & 7,00 & 7,90 & 95,12 & 24,64 \\
\hline 531 & 30,80 & 0,20 & 3,10 & 0,08 & 1,00 & 5,70 & 4,40 & 20,00 & 10,40 & 32,10 & 3,90 & 121,0 & 44,00 & 0,08 & 7,10 & 7,94 & - & 22,14 \\
\hline 547 & 11,20 & 0,20 & 3,00 & 0,56 & 2,00 & 2,80 & 1,10 & 523,7 & 7,90 & 11,50 & 2,80 & 3125 , & 1275 , & 0,07 & 6,80 & 7,54 & - & 23,66 \\
\hline 553 & 6,60 & 0,50 & - & 0,04 & 0,20 & 0,60 & 0,30 & 33,30 & 40,20 & 2,80 & 10,60 & 54,00 & 17,00 & 0,05 & 6,00 & 7,18 & - & 20,96 \\
\hline 561 & 13,00 & 0,30 & 0,90 & 0,03 & 0,70 & 2,30 & 1,20 & 5,30 & 3,00 & 10,70 & 2,60 & 99,00 & 21,00 & 0,06 & 6,90 & 8,79 & 95,08 & 19,16 \\
\hline 572 & 53,80 & 0,30 & - & 0,04 & 1,70 & 10,40 & 3,70 & 34,70 & 19,40 & 41,00 & 1,70 & 79,00 & 13,00 & 0,11 & 7,70 & 7,27 & - & 21,15 \\
\hline 580 & 20,00 & 0,10 & 4,30 & 0,03 & 0,10 & 5,00 & 2,40 & 7,30 & 2,50 & 22,20 & 1,30 & 19,00 & 6,00 & 0,10 & 7,40 & 8,52 & 94,84 & 20,64 \\
\hline 608 & 38,60 & 0,40 & 0,80 & 0,05 & 1,60 & 32,80 & 36,70 & 23,70 & 11,40 & 233,0 & 1,60 & 6,00 & 12,00 & 0,40 & 7,60 & 8,25 & 93,90 & 21,70 \\
\hline 615 & 71,80 & 0,70 & - & 0,02 & 3,00 & 13,30 & 7,30 & 22,00 & 12,90 & 63,10 & 9,10 & 59,00 & 15,00 & 0,14 & 7,10 & 6,99 & - & 23,48 \\
\hline 616 & 17,40 & 0,30 & - & 0,44 & 2,20 & 3,40 & 1,30 & 99,70 & 9,40 & 13,50 & 2,80 & 550,0 & 256,0 & 0,07 & 7,00 & 6,74 & - & 22,14 \\
\hline 619 & 29,20 & 1,00 & - & 0,07 & 1,80 & 5,70 & 1,70 & 39,30 & 21,30 & 21,20 & 5,90 & 227,0 & 50,00 & 0,08 & 6,90 & 5,56 & - & 24,78 \\
\hline 620 & 46,00 & 1,30 & - & 0,03 & 2,60 & 9,70 & 4,20 & 18,70 & 16,90 & 41,50 & 9,30 & 67,00 & 16,00 & 0,13 & 6,90 & 5,27 & - & 22,76 \\
\hline 632 & 27,00 & 0,70 & - & 0,06 & 1,80 & 5,50 & 2,10 & 39,30 & 10,90 & 22,40 & 3,40 & 148,0 & 29,00 & 0,09 & 7,10 & 7,19 & - & 27,64 \\
\hline 634 & 52,00 & 0,50 & - & 0,04 & 6,00 & 14,30 & 4,00 & 4,00 & 6,50 & 51,90 & 2,10 & 32,00 & 9,00 & 0,17 & 7,60 & 8,05 & - & 22,41 \\
\hline 635 & 100,0 & 0,30 & 1,40 & 0,04 & 4,40 & 20,40 & 6,00 & 6,70 & 8,40 & 75,70 & 2,00 & 29,00 & 5,00 & 0,19 & 7,90 & 7,80 & 90,46 & 22,78 \\
\hline 648 & 141,0 & 0,20 & 0,30 & 0,05 & 2,80 & 45,50 & 25,60 & 11,00 & 1,00 & 219,0 & 1,10 & 59,00 & 15,00 & 0,35 & 8,30 & 7,82 & 90,74 & 22,80 \\
\hline 652 & 212,0 & 0,50 & - & 0,06 & 2,10 & 48,50 & 36,50 & 6,30 & 4,00 & 271,0 & 2,10 & 18,00 & 6,00 & 0,40 & 8,20 & 7,19 & - & 22,93 \\
\hline
\end{tabular}

Anexo D.3. Valores (ou estados) mensurados das 60 microbacias estudadas, com as variáveis dos parâmetros químicos e físicos da água nas estações secas

\begin{tabular}{crrrrrrrrrrrrrrrrrrr}
\hline ID & \multicolumn{1}{c}{ AT } & NN & \multicolumn{1}{l}{ NI } & PT & KA & CA & MG & \multicolumn{1}{l}{ SE } & AZ & DU & CO & \multicolumn{1}{l}{ CR } & \multicolumn{1}{c}{ TU } & CN & pH & OD & SA & TG \\
\hline 1 & 10,60 & 0,20 & 2,00 & 0,01 & 0,80 & 1,20 & 0,80 & 11,00 & 7,40 & 6,10 & 2,70 & 14,00 & 3,00 & 0,06 & 6,80 & 8,40 & - & 19,82 \\
2 & 3,40 & 0,20 & - & 0,03 & 0,40 & 0,80 & 0,30 & 19,30 & 3,00 & 3,30 & 1,70 & 1,00 & 10,00 & 0,04 & 6,50 & 8,54 & - & 18,58 \\
3 & 7,80 & 0,30 & - & 0,02 & 2,40 & 1,60 & 1,10 & 5,30 & 4,50 & 8,60 & 2,00 & 6,00 & 8,00 & 0,05 & 6,80 & 8,64 & - & 20,06 \\
8 & 12,60 & 0,20 & 1,40 & 0,04 & 1,30 & 2,00 & 1,00 & 17,00 & 3,00 & 9,00 & 2,30 & 77,00 & 15,00 & 0,04 & 7,00 & 8,80 & 91,30 & 17,18 \\
15 & 7,20 & 0,20 & 3,50 & 0,01 & 1,00 & 1,40 & 0,80 & 13,30 & 2,00 & 6,70 & 2,20 & 25,00 & 5,00 & 0,05 & 6,70 & 8,89 & 91,94 & 17,00 \\
20 & 12,20 & 0,30 & 0,20 & 0,01 & 1,00 & 2,00 & 1,10 & 16,00 & 6,00 & 9,30 & 6,20 & 15,00 & 13,00 & 0,06 & 6,50 & 7,21 & - & 19,00 \\
43 & 6,20 & 0,20 & 3,70 & 0,02 & 1,10 & 1,10 & 0,60 & 163,30 & 1,50 & 5,30 & 2,40 & 31,00 & 8,00 & 0,04 & 6,60 & 8,85 & 94,06 & 18,30 \\
44 & 12,00 & 0,40 & - & 0,09 & 1,30 & 2,70 & 1,40 & 29,70 & 2,00 & 12,20 & 1,00 & 154,00 & 49,00 & 0,05 & 7,30 & 8,67 & - & 19,08 \\
59 & 17,80 & 0,40 & 1,90 & 0,03 & 2,00 & 3,00 & 0,90 & 10,00 & 9,90 & 11,20 & 3,60 & 11,00 & 9,00 & 0,06 & 6,90 & 8,69 & - & 18,82 \\
60 & 42,00 & 0,30 & 0,40 & 0,03 & 5,60 & 8,00 & 2,50 & 15,30 & 2,50 & 30,20 & 0,80 & 34,00 & 6,00 & 0,10 & 7,90 & 8,74 & - & 18,86 \\
75 & 10,00 & 0,20 & 1,30 & 0,03 & 1,10 & 1,90 & 0,50 & 137,00 & 4,00 & 6,90 & 4,00 & 47,00 & 13,00 & 0,04 & 6,60 & 9,12 & 97,70 & 18,72
\end{tabular}


Anexo D.3. Valores (ou estados) mensurados das 60 microbacias estudadas, com as variáveis dos parâmetros químicos e físicos da água nas estações secas

\begin{tabular}{|c|c|c|c|c|c|c|c|c|c|c|c|c|c|c|c|c|c|c|}
\hline ID & AT & $\mathrm{NN}$ & NI & PT & KA & $\mathrm{CA}$ & MG & SE & $\mathrm{AZ}$ & DU & $\mathrm{CO}$ & $\mathrm{CR}$ & $\mathrm{TU}$ & $\mathrm{CN}$ & $\mathrm{pH}$ & OD & SA & $\mathrm{TG}$ \\
\hline 76 & 84,00 & 0,20 & 4,40 & 0,04 & 3,00 & 16,60 & 6,20 & 15,00 & 3,00 & 66,90 & 2,10 & 40,00 & 8,00 & 0,14 & 7,80 & 9,01 & 90,90 & 15,80 \\
\hline 77 & 15,80 & 0,20 & 0,40 & 0,03 & 1,50 & 4,10 & 0,90 & 16,00 & 10,40 & 14,10 & 1,00 & 3,00 & 11,00 & 0,07 & 7,40 & 8,64 & - & 19,90 \\
\hline 83 & 18,60 & 0,20 & 0,40 & 0,02 & 1,10 & 3,60 & 1,20 & 20,70 & 1,00 & 14,10 & 1,70 & 54,00 & 11,00 & 0,06 & 7,30 & 9,57 & 94,78 & 14,88 \\
\hline 85 & 7,60 & 0,20 & 1,00 & 0,02 & 0,20 & 1,30 & 0,50 & 40,70 & 3,50 & 5,30 & 2,20 & 3,00 & 3,00 & 0,04 & 6,80 & 8,44 & 91,76 & 19,30 \\
\hline 87 & 107,80 & 0,20 & 0,20 & 0,02 & 4,60 & 15,20 & 4,90 & 9,30 & 6,50 & 58,00 & 2,70 & 26,00 & 19,00 & 0,16 & 7,80 & 7,44 & - & 24,06 \\
\hline 88 & 80,60 & 0,30 & 0,60 & 0,02 & 7,60 & 19,00 & 5,20 & 18,30 & 1,00 & 68,50 & 1,00 & 47,00 & 11,00 & 0,15 & 8,10 & 7,67 & - & 19,76 \\
\hline 120 & 13,80 & 0,20 & 1,50 & 0,02 & 0,60 & 2,70 & 0,90 & 13,00 & 3,50 & 10,30 & 3,10 & 11,00 & 2,00 & 0,04 & 6,90 & 8,95 & 93,52 & 17,30 \\
\hline 137 & 12,40 & 0,30 & 2,80 & 0,04 & 3,00 & 3,40 & 1,00 & 8,00 & 10,90 & 12,40 & 7,90 & 43,00 & 8,00 & 0,06 & 6,40 & 5,07 & - & 15,94 \\
\hline 139 & 20,60 & 0,20 & 2,80 & 0,05 & 2,00 & 4,70 & 1,30 & 120,30 & 1,50 & 17,00 & 2,10 & 63,00 & 15,00 & 0,05 & 7,20 & 9,23 & 92,84 & 15,70 \\
\hline 140 & 60,20 & 0,50 & 0,80 & 0,03 & 8,00 & 12,60 & 4,50 & 23,30 & 12,40 & 49,70 & 7,70 & 73,00 & 19,00 & 0,13 & 7,10 & 5,53 & - & 24,52 \\
\hline 142 & 39,00 & 0,20 & 0,30 & 0,03 & 1,60 & 7,70 & 2,70 & 20,30 & 1,50 & 30,30 & 3,00 & 120,00 & 24,00 & 0,07 & 7,30 & 8,81 & 92,98 & 17,90 \\
\hline 150 & 10,60 & 0,40 & 3,80 & 0,02 & 2,20 & 2,80 & 0,70 & 19,70 & 5,00 & 9,80 & 2,70 & 19,00 & 17,00 & 0,06 & 6,80 & 8,39 & - & 19,30 \\
\hline 171 & 9,80 & 0,20 & - & 0,03 & 1,30 & 1,10 & 0,70 & 5,30 & 3,00 & 5,70 & 2,00 & 18,00 & 51,00 & 0,04 & 6,90 & 8,51 & - & 19,30 \\
\hline 173 & 8,00 & 0,40 & 0,20 & 0,03 & 1,80 & 0,90 & 0,70 & 7,00 & 20,40 & 4,90 & 8,10 & 19,00 & 21,00 & 0,05 & 6,20 & 8,09 & - & 20,52 \\
\hline 174 & 12,40 & 0,30 & 5,20 & 0,05 & 1,20 & 1,50 & 1,60 & 10,00 & 4,00 & 10,50 & 4,00 & 121,00 & 22,00 & 0,05 & 6,70 & 10,09 & 93,30 & 11,82 \\
\hline 188 & 30,60 & 0,20 & 0,80 & 0,04 & 2,10 & 6,00 & 2,10 & 14,30 & 2,00 & 23,60 & 3,70 & 146,00 & 29,00 & 0,06 & 7,10 & 9,23 & 89,86 & 14,10 \\
\hline 199 & 34,80 & 0,20 & 1,20 & 0,04 & 1,10 & 5,30 & 2,30 & 23,30 & 5,50 & 22,70 & 3,50 & 74,00 & 19,00 & 0,06 & 7,20 & 9,66 & 91,78 & 13,06 \\
\hline 200 & 8,80 & 0,20 & 1,20 & 0,04 & 1,40 & 1,40 & 0,80 & 49,00 & 4,00 & 6,90 & 2,20 & 73,00 & 22,00 & 0,04 & 6,80 & 8,70 & - & 17,84 \\
\hline 257 & 17,60 & 0,20 & 1,40 & 0,04 & 0,40 & 2,70 & 1,80 & 29,00 & 2,00 & 14,10 & 3,20 & 77,00 & 17,00 & 0,05 & 6,90 & 10,19 & 95,58 & 12,66 \\
\hline 315 & 12,00 & 0,30 & 4,40 & 0,04 & 2,60 & 4,00 & 1,20 & 16,00 & 2,00 & 14,90 & 1,20 & 15,00 & 3,00 & 0,06 & 7,20 & 8,97 & - & 15,32 \\
\hline 318 & 30,20 & 0,30 & 1,00 & 0,05 & 7,10 & 4,40 & 1,40 & 37,30 & 8,40 & 16,60 & 1,20 & 96,00 & 53,00 & 0,08 & 7,60 & 7,95 & - & 19,96 \\
\hline 322 & 16,60 & 0,30 & - & 0,03 & 0,90 & 3,60 & 1,40 & 25,70 & 6,00 & 14,80 & 2,70 & 7,00 & 51,00 & 0,05 & 7,00 & 9,12 & - & 17,12 \\
\hline 323 & 33,20 & 0,20 & - & 0,03 & 3,00 & 5,50 & 3,00 & & 4,00 & 25,90 & 2,10 & 13,00 & 7,00 & 0,06 & 7,40 & 9,27 & - & 14,30 \\
\hline 352 & 11,60 & 0,20 & - & 0,03 & 1,40 & 2,10 & 1,20 & 16,00 & 1,00 & 10,10 & 0,90 & 11,00 & 15,00 & 0,05 & 7,30 & 9,19 & - & 15,80 \\
\hline 393 & 85,80 & 0,30 & 1,10 & 0,04 & 2,50 & 15,30 & 5,00 & 32,30 & 14,90 & 58,50 & 10,90 & 34,00 & 9,00 & 0,14 & 7,10 & 6,07 & - & 17,80 \\
\hline 403 & 10,80 & 0,20 & - & 0,03 & 1,30 & 2,30 & 1,10 & 4,70 & 1,00 & 10,00 & 0,90 & 5,00 & 11,00 & 0,05 & 7,30 & 8,86 & - & 20,48 \\
\hline 409 & 20,40 & 0,20 & 2,20 & 0,04 & 2,70 & 4,00 & 2,70 & 238,70 & 3,50 & 21,30 & 2,90 & 167,00 & 49,00 & 0,07 & 7,00 & 8,61 & 90,08 & 17,50 \\
\hline 413 & 11,60 & 0,20 & 2,00 & 0,02 & 2,60 & 2,10 & 1,50 & 8,30 & 11,90 & 11,30 & 2,30 & 24,00 & 5,00 & 0,06 & 6,90 & 8,86 & - & 17,64 \\
\hline 414 & 18,00 & 0,30 & - & 0,09 & 1,30 & 3,30 & 1,20 & 14,30 & 3,00 & 13,20 & 0,90 & 11,00 & 41,00 & 0,05 & 7,60 & 8,78 & - & 21,30 \\
\hline 485 & 14,00 & 0,20 & 0,40 & 0,04 & 1,00 & 3,50 & 1,30 & 5,70 & 2,50 & 14,20 & 0,90 & 13,00 & 4,00 & 0,06 & 7,40 & 9,36 & - & 16,04 \\
\hline 508 & 12,00 & 0,20 & 4,20 & 0,02 & 3,40 & 3,10 & 1,50 & 18,00 & 2,00 & 13,70 & 1,90 & 41,00 & 10,00 & 0,06 & 7,00 & 9,02 & - & 17,36 \\
\hline 531 & 35,60 & 0,20 & - & 0,02 & 0,60 & 6,00 & 5,70 & 14,30 & 7,90 & 38,50 & 1,10 & 2,00 & 3,00 & 0,07 & 7,70 & 9,07 & - & 15,60 \\
\hline 547 & 14,00 & 0,20 & 2,30 & 0,03 & 1,50 & 3,10 & 1,10 & 155,70 & 2,50 & 12,10 & 2,80 & 66,00 & 15,00 & 0,05 & 6,90 & 9,10 & 96,40 & 18,16 \\
\hline 553 & 3,60 & 0,20 & - & 0,03 & 0,20 & 0,60 & 0,30 & 9,30 & 0,50 & 2,70 & 3,60 & 7,00 & 13,00 & 0,04 & 6,20 & 8,73 & - & 13,50 \\
\hline 561 & 13,40 & 0,30 & 1,70 & 0,03 & 0,70 & 2,00 & 1,30 & 5,70 & 3,50 & 10,20 & 2,90 & 35,00 & 11,00 & 0,05 & 6,90 & 9,57 & 92,70 & 13,08 \\
\hline 572 & 56,20 & 0,30 & - & 0,05 & 2,40 & 10,10 & 3,90 & 4,30 & 2,00 & 41,10 & 1,80 & 24,00 & 66,00 & 0,10 & 7,70 & 7,11 & - & 19,72 \\
\hline 580 & 20,20 & 0,20 & 2,60 & 0,02 & 0,40 & 4,00 & 2,10 & 5,70 & 1,50 & 18,60 & 1,50 & 10,00 & 4,00 & 0,06 & 7,30 & 9,72 & 94,94 & 13,32 \\
\hline 608 & 98,80 & 0,40 & 0,60 & 0,01 & 3,00 & 30,30 & 21,10 & 8,30 & 2,50 & 162,50 & 2,00 & 33,00 & 9,00 & 0,33 & 7,90 & 6,25 & - & 19,56 \\
\hline 615 & 50,40 & 1,20 & - & 0,02 & 2,80 & 7,10 & 4,30 & 12,00 & 37,70 & 35,40 & 32,10 & 20,00 & 22,00 & 0,10 & 6,40 & 6,34 & - & 17,12 \\
\hline 616 & 29,40 & 0,30 & - & 0,02 & 1,50 & 6,20 & 1,80 & 11,00 & 3,50 & 23,10 & 3,70 & 47,00 & 11,00 & 0,07 & 7,10 & 9,24 & - & 18,44 \\
\hline 619 & 28,80 & 0,20 & - & 0,03 & 1,60 & 5,10 & 1,60 & 21,70 & 3,00 & 19,40 & 2,30 & 65,00 & 15,00 & 0,07 & 7,30 & 8,40 & - & 16,38 \\
\hline 620 & 43,40 & 0,30 & - & 0,02 & 2,70 & 9,90 & 4,90 & 15,00 & 6,00 & 44,90 & 4,40 & 13,00 & 47,00 & 0,11 & 7,20 & 6,70 & - & 17,04 \\
\hline 632 & 40,80 & 0,20 & - & 0,63 & 1,60 & 7,30 & 2,70 & 28,30 & 2,00 & 29,50 & 1,00 & 130,00 & 28,00 & 0,08 & 7,80 & 9,14 & - & 15,88 \\
\hline 634 & 45,00 & 0,20 & 10,00 & 0,02 & 8,00 & 18,00 & 5,00 & 20,00 & 3,50 & 65,70 & 2,00 & 8,00 & 2,00 & 0,15 & 7,60 & 9,42 & 99,62 & 17,46 \\
\hline 635 & 251,40 & 0,30 & 0,40 & 0,02 & 5,70 & 46,30 & 13,30 & 29,70 & 5,50 & 170,20 & 4,00 & 108,00 & 57,00 & 0,37 & 8,00 & 2,51 & - & 18,33 \\
\hline 648 & 249,60 & 0,40 & 0,60 & 0,02 & 3,80 & 64,70 & 43,50 & 7,30 & 4,00 & 340,60 & 3,20 & 22,00 & 5,00 & 0,45 & 8,10 & 7,34 & - & 15,98 \\
\hline 652 & 223,00 & 0,20 & 2,50 & 0,05 & 3,10 & 36,00 & 23,50 & 17,00 & 0,50 & 186,40 & 2,00 & 25,00 & 8,00 & 0,31 & 8,30 & 8,60 & 86,76 & 15,78 \\
\hline
\end{tabular}


Anexo D.4. Valores (ou estados) mensurados das 60 microbacias estudadas, com as variáveis sobre as características do segmento do riacho de amostragem de peixes nas estações chuvosas

\begin{tabular}{|c|c|c|c|c|c|c|c|c|}
\hline ID & DR & BM & $\mathrm{AB}$ & LP & $\mathrm{CV}$ & AP & SO & IS \\
\hline 1 & - & - & - & 3 & 2 & 0 & 0,00 & 127.867 \\
\hline 2 & - & - & - & 1 & 4 & 236 & 68,20 & - \\
\hline 3 & - & - & - & 2 & 4 & 83 & 35,33 & - \\
\hline 8 & 1,73 & 7,97 & 98,57 & 2 & 3 & 56 & 27,13 & 50.957 \\
\hline 15 & 1,42 & 2,89 & 134,29 & 2 & 5 & 159 & 1,58 & 4.209 \\
\hline 20 & - & - & - & 3 & 3 & 1 & 2,87 & 26.400 \\
\hline 43 & 0,79 & 4,36 & 134,29 & 2 & 4 & 168 & 69,00 & 8.395 \\
\hline 44 & - & & - & 1 & 5 & 72 & 1,00 & - \\
\hline 47 & - & & - & 2 & 1 & 67 & 37,20 & - \\
\hline 59 & - & 22,31 & 3,50 & 2 & 1 & 0 & 0,00 & 106.133 \\
\hline 60 & - & 15,36 & 210,00 & 3 & 2 & 7 & 2,00 & 128.167 \\
\hline 75 & 0,26 & 8,67 & 83,57 & 3 & 2 & 66 & 4,93 & 89.160 \\
\hline 76 & 0,14 & 8,11 & 57,14 & 3 & 2 & 35 & 8,40 & 22.780 \\
\hline 77 & - & - & - & 1 & 3 & 31 & 9,00 & 80.140 \\
\hline 83 & 0,29 & 5,87 & 27,14 & 2 & 2 & 7 & 0,00 & 15.680 \\
\hline 85 & 1,31 & 7,90 & 170,00 & 1 & 5 & 0 & 40,28 & 25.733 \\
\hline 87 & - & 13,91 & 180,00 & 3 & 1 & 6 & 0,00 & 32.523 \\
\hline 88 & - & 19,43 & 220,00 & 3 & 1 & 0 & 0,00 & 134.675 \\
\hline 120 & 0,42 & 8,91 & 135,71 & 3 & 1 & 21 & 12,47 & 54.417 \\
\hline 137 & - & - & - & 3 & 2 & 12 & 17,27 & - \\
\hline 139 & 0,78 & 4,14 & 87,86 & 1 & 4 & 35 & 9,53 & 52.327 \\
\hline 140 & - & 4,82 & 33,33 & 3 & 1 & 0 & 0,00 & 141.600 \\
\hline 142 & 0,77 & 8,00 & 125,83 & 3 & 1 & 5 & 14,33 & 67.989 \\
\hline 150 & - & 10,34 & 160,00 & 3 & 5 & 46 & 34,60 & 22.210 \\
\hline 171 & - & - & - & 1 & 4 & 119 & 63,60 & - \\
\hline 173 & - & - & - & 2 & 5 & 106 & 47,87 & 35.706 \\
\hline 174 & 2,78 & 2,92 & 66,67 & 2 & 4 & 116 & 49,47 & 19.392 \\
\hline 188 & 1,16 & 12,17 & 160,71 & 2 & 1 & 1 & 1,60 & 125.600 \\
\hline 199 & 1,01 & 4,26 & 75,71 & 2 & 4 & 91 & 55,13 & 6.548 \\
\hline 200 & - & - & - & 1 & 4 & 77 & 26,20 & - \\
\hline 257 & 0,87 & 4,17 & 112,86 & 2 & 5 & 113 & 48,67 & 3.846 \\
\hline 308 & - & 0,00 & 0,00 & 1 & 5 & 136 & 61,60 & - \\
\hline 315 & 2,12 & - & - & 1 & 5 & - & 58,20 & - \\
\hline 318 & - & - & - & 1 & 4 & 0 & 60,00 & 12.294 \\
\hline 322 & - & - & - & 2 & 3 & 73 & 19,93 & - \\
\hline 323 & - & - & - & 2 & 5 & 107 & 60,87 & - \\
\hline 352 & - & - & - & 2 & 4 & 50 & 55,53 & - \\
\hline 393 & - & 7,34 & 90,00 & 3 & 2 & 17 & 7,93 & 57.527 \\
\hline 403 & - & - & - & 2 & 1 & 1 & 0,53 & - \\
\hline 409 & 1,15 & 3,94 & 75,00 & 2 & 5 & 126 & 32,67 & 17.108 \\
\hline 413 & - & - & - & 2 & 1 & 1 & 0,00 & - \\
\hline 414 & - & - & - & 3 & 1 & 0 & 0,00 & - \\
\hline
\end{tabular}


Anexo D.4. Valores (ou estados) mensurados das 60 microbacias estudadas, com as variáveis sobre as características do segmento do riacho de amostragem de peixes nas estações chuvosas

\begin{tabular}{ccccccccc}
\hline ID & DR & BM & AB & LP & CV & AP & SO & IS \\
\hline 485 & - & - & - & 3 & 4 & 42 & 20,20 & - \\
508 & - & 14,61 & 120,00 & 2 & 1 & 26 & 0,00 & 87.790 \\
531 & 1,63 & 4,57 & 70,00 & 2 & 3 & 80 & 35,80 & 32.743 \\
547 & 1,08 & 10,30 & 122,86 & 3 & 2 & 79 & 16,60 & 15.067 \\
553 & - & & 71,67 & 2 & 5 & 143 & 63,67 & - \\
561 & 0,85 & 0,00 & 0,00 & 1 & 3 & 0 & 61,26 & 3.003 \\
572 & - & - & - & 2 & 5 & 115 & 39,29 & - \\
580 & 1,77 & 0,00 & 0,00 & 1 & 2 & 20 & 26,40 & 52.532 \\
608 & - & 4,24 & 150,00 & 3 & 2 & 149 & 50,80 & 15.100 \\
615 & 1,49 & 6,20 & 180,00 & 1 & 3 & - & 46,47 & - \\
616 & 0,39 & 7,83 & 269,29 & 3 & 1 & 18 & 9,73 & - \\
619 & 1,13 & 2,81 & 87,86 & 3 & 1 & - & 14,87 & - \\
620 & 1,19 & 9,35 & 174,17 & 3 & 2 & - & 0,00 & - \\
632 & 0,73 & 7,17 & 222,14 & 3 & 2 & - & 19,40 & - \\
634 & 1,01 & 16,91 & 108,57 & 2 & 1 & - & 0,00 & - \\
635 & 0,38 & 5,53 & 141,43 & 3 & 3 & 33 & 11,00 & 33.903 \\
648 & 0,57 & 6,91 & 185,00 & 3 & 4 & 157 & 55,93 & 2.941 \\
652 & 0,83 & 3,46 & 147,14 & 3 & 4 & - & 31,67 & - \\
\hline
\end{tabular}

Anexo D.4. Valores (ou estados) mensurados das 60 microbacias estudadas, com as variáveis sobre as características do segmento do riacho de amostragem de peixes nas estações secas

\begin{tabular}{ccccccccc}
\hline ID & DR & BM & AB & LP & CV & AP & SO & IS \\
\hline 1 & - & - & - & 3 & 2 & 0 & 0,00 & - \\
2 & - & - & - & 1 & 4 & 239 & 54,00 & - \\
3 & - & - & - & 2 & 4 & 115 & 26,47 & - \\
8 & 1,73 & 7,97 & 98,57 & 2 & 3 & 62 & 21,60 & 23.041 \\
15 & 1,42 & 2,89 & 134,29 & 2 & 5 & 197 & 55,07 & 2.749 \\
20 & - & - & - & 3 & 3 & 0 & 35,07 & - \\
43 & 0,79 & 4,36 & 134,29 & 2 & 4 & 212 & 62,80 & 3.668 \\
44 & - & 0,00 & - & 1 & 5 & 56 & 20,07 & - \\
59 & - & 0,00 & - & 2 & 1 & 0 & 0,00 & - \\
60 & - & 22,31 & 3,50 & 2 & 1 & 5 & 0,00 & - \\
75 & - & 15,36 & 210,00 & 3 & 2 & 56 & 1,47 & 53.944 \\
76 & 0,26 & 8,67 & 83,57 & 3 & 2 & 47 & 4,73 & 93.687 \\
77 & 0,14 & 8,11 & 57,14 & 3 & 2 & 17 & 5,47 & - \\
83 & - & - & - & 1 & 3 & 7 & 0,00 & 75.289 \\
85 & 0,29 & 5,87 & 27,14 & 2 & 2 & 139 & 31,60 & 9.768
\end{tabular}


Anexo D.4. Valores (ou estados) mensurados das 60 microbacias estudadas, com as variáveis sobre as características do segmento do riacho de amostragem de peixes nas estações secas

\begin{tabular}{|c|c|c|c|c|c|c|c|c|}
\hline ID & DR & $\mathrm{BM}$ & $\mathrm{AB}$ & LP & $\mathrm{CV}$ & AP & SO & IS \\
\hline 87 & 1,31 & 7,90 & 170,00 & 1 & 5 & 0 & 0,00 & - \\
\hline 88 & - & 13,91 & 180,00 & 3 & 1 & 0 & 0,00 & - \\
\hline 120 & - & 19,43 & 220,00 & 3 & 1 & 31 & 9,00 & 36.312 \\
\hline 137 & 0,42 & 8,91 & 135,71 & 3 & 1 & 17 & 1,80 & - \\
\hline 139 & - & - & - & 3 & 2 & 0 & 0,00 & 38.586 \\
\hline 140 & 0,78 & 4,14 & 87,86 & 1 & 4 & 0 & 0,00 & - \\
\hline 142 & - & 4,82 & 33,33 & 3 & 1 & 4 & 12,00 & 44.064 \\
\hline 150 & 0,77 & 8,00 & 125,83 & 3 & 1 & 56 & 18,33 & - \\
\hline 171 & - & 10,34 & 160,00 & 3 & 5 & 142 & 59,40 & - \\
\hline 173 & - & - & - & 1 & 4 & 119 & 58,20 & - \\
\hline 174 & - & - & - & 2 & 5 & 116 & 49,67 & 6.327 \\
\hline 188 & 2,78 & 2,92 & 66,67 & 2 & 4 & 1 & 1,33 & 86.888 \\
\hline 199 & 1,16 & 12,17 & 160,71 & 2 & 1 & 90 & 43,27 & 1.318 \\
\hline 200 & 1,01 & 4,26 & 75,71 & 2 & 4 & 58 & 0,20 & - \\
\hline 257 & - & - & - & 1 & 4 & 87 & 64,80 & 394,3226 \\
\hline 315 & 0,87 & 4,17 & 112,86 & 2 & 5 & 147 & 16,20 & - \\
\hline 318 & - & 0,00 & 0,00 & 1 & 5 & 2 & 27,27 & - \\
\hline 322 & 2,12 & - & - & 1 & 5 & 56 & 10,20 & - \\
\hline 323 & - & - & - & 1 & 4 & 87 & 45,40 & - \\
\hline 352 & - & - & - & 2 & 3 & 240 & 18,40 & - \\
\hline 393 & - & - & - & 2 & 5 & 19 & 4,60 & - \\
\hline 403 & - & - & - & 2 & 4 & 3 & 3,00 & - \\
\hline 409 & - & 7,34 & 90,00 & 3 & 2 & 94 & 26,67 & 1.230 \\
\hline 413 & - & - & - & 2 & 1 & 0 & 0,00 & - \\
\hline 414 & 1,15 & 3,94 & 75,00 & 2 & 5 & 2 & 0,00 & - \\
\hline 485 & - & - & - & 2 & 1 & 56 & 3,07 & - \\
\hline 508 & - & - & - & 3 & 1 & 21 & 1,20 & - \\
\hline 531 & - & - & - & 3 & 4 & 54 & 40,40 & - \\
\hline 547 & - & 14,61 & 120,00 & 2 & 1 & 46 & 12,33 & 52.734 \\
\hline 553 & 1,63 & 4,57 & 70,00 & 2 & 3 & 55 & 58,47 & - \\
\hline 561 & 1,08 & 10,30 & 122,86 & 3 & 2 & 86 & 59,93 & 1.723 \\
\hline 572 & - & 0 & 71,67 & 2 & 5 & 106 & 46,28 & - \\
\hline 580 & 0,85 & 0,00 & 0,00 & 1 & 3 & 15 & 37,20 & 26.607 \\
\hline 608 & - & - & - & 2 & 5 & 94 & 31,60 & - \\
\hline 615 & 1,77 & 0,00 & 0,00 & 1 & 2 & 47 & 40,60 & - \\
\hline 616 & - & 4,24 & 150,00 & 3 & 2 & 30 & 2,60 & - \\
\hline 619 & 1,49 & 6,20 & 180,00 & 1 & 3 & 28 & 18,33 & - \\
\hline 620 & 0,39 & 7,83 & 269,29 & 3 & 1 & 12 & 0,00 & - \\
\hline 632 & 1,13 & 2,81 & 87,86 & 3 & 1 & 28 & 7,20 & - \\
\hline 634 & 1,19 & 9,35 & 174,17 & 3 & 2 & 0 & 0,00 & 68.300 \\
\hline 635 & 0,73 & 7,17 & 222,14 & 3 & 2 & $?$ & $?$ & - \\
\hline 648 & 1,01 & 16,91 & 108,57 & 2 & 1 & 130 & 24,20 & - \\
\hline 652 & 0,38 & 5,53 & 141,43 & 3 & 3 & 100 & 49,40 & 8.302 \\
\hline
\end{tabular}


Anexo D.5. Valores (ou estados) mensurados das 60 microbacias estudadas, com as variáveis sobre as métricas de canal nas estações chuvosas

\begin{tabular}{|c|c|c|c|c|c|c|c|c|c|}
\hline ID & $\mathrm{NU}$ & $\mathrm{PC}$ & $\mathrm{RP}$ & QT & $\mathrm{VE}$ & PF & UB & $\mathrm{VM}$ & LM \\
\hline 1 & 11 & 0,57 & 0,54 & 0,00 & 31,50 & 7,75 & 36,36 & 1,64 & 261,33 \\
\hline 2 & 11 & 0,10 & 0,03 & 9,75 & 42,40 & 5,70 & 90,91 & 2,14 & 123,16 \\
\hline 3 & 13 & 0,63 & 0,54 & 2,85 & 8,70 & 0,00 & 69,23 & 2,15 & 327,50 \\
\hline 8 & 12 & 0,20 & 0,15 & 1,35 & 38,30 & 1,00 & 83,33 & 2,25 & 323,29 \\
\hline 15 & 17 & 0,13 & 0,05 & 21,30 & 8,50 & 1,65 & 94,12 & 2,19 & 127,32 \\
\hline 20 & 14 & 0,08 & 0,35 & 0,00 & 74,00 & 40,00 & 42,86 & 1,86 & 196,97 \\
\hline 43 & 12 & 0,00 & 0,00 & 8,00 & 13,90 & 0,50 & 66,67 & 2,25 & 229,47 \\
\hline 44 & 15 & 0,88 & 0,72 & 5,25 & 24,50 & 6,35 & 80,00 & 2,13 & 234,61 \\
\hline 47 & 15 & 0,15 & 0,03 & 1,10 & 103,75 & 9,95 & 60,00 & 2,29 & 281,37 \\
\hline 59 & 13 & 0,44 & 0,70 & 0,75 & 94,70 & 0,00 & 15,38 & 1,69 & 278,97 \\
\hline 60 & 16 & 0,33 & 0,52 & 1,00 & 22,05 & 19,50 & 50,00 & 1,81 & 180,66 \\
\hline 75 & 17 & 0,55 & 0,28 & 3,10 & 23,85 & 9,25 & 76,47 & 1,76 & 249,23 \\
\hline 76 & 10 & 0,25 & 0,13 & 2,75 & 13,65 & 1,25 & 20,00 & 1,55 & 316,72 \\
\hline 77 & 13 & 0,18 & 0,15 & 4,25 & 138,00 & 70,00 & 46,15 & 1,77 & 276,35 \\
\hline 83 & 8 & 0,14 & 0,08 & 0,00 & 51,75 & 0,00 & 0,00 & 2,25 & 359,74 \\
\hline 85 & 13 & 0,18 & 0,05 & 7,85 & 15,90 & 3,35 & 76,92 & 2,00 & 352,31 \\
\hline 87 & 14 & 0,56 & 0,20 & 1,00 & 39,95 & 34,00 & 71,43 & 1,67 & 294,47 \\
\hline 88 & 16 & 0,14 & 0,69 & 0,00 & 140,90 & 160,20 & 0,00 & 1,38 & 345,93 \\
\hline 120 & 8 & 0,00 & 0,00 & 0,75 & 23,50 & 0,00 & 62,50 & 2,63 & 206,58 \\
\hline 137 & 13 & 0,44 & 0,70 & 1,35 & 62,3 & 0,00 & 92,31 & 1,38 & 110,13 \\
\hline 139 & 7 & 0,00 & 0,00 & 3,75 & 29,70 & 1,60 & 14,29 & 2,13 & 229,59 \\
\hline 140 & 15 & 0,50 & 0,28 & 0,00 & 44,95 & 49,15 & 66,67 & 1,27 & 314,29 \\
\hline 142 & 8 & 0,14 & 0,01 & 0,25 & 21,90 & 1,25 & 12,50 & 2,38 & 233,83 \\
\hline 150 & 8 & 0,33 & 0,15 & 3,00 & 19,35 & 2,00 & 50,00 & 1,88 & 280,26 \\
\hline 171 & 15 & 0,15 & 0,05 & 17,50 & 68,25 & 4,00 & 73,33 & 2,07 & 156,97 \\
\hline 173 & 10 & 0,43 & 0,02 & 2,75 & 42,90 & 12,00 & 100,00 & 1,78 & 158,68 \\
\hline 174 & 24 & 0,20 & 0,22 & 12,40 & 16,00 & 2,30 & 58,33 & 1,79 & 196,99 \\
\hline 188 & 14 & 0,17 & 0,12 & 0,00 & 108,50 & 16,40 & 14,29 & 1,64 & 393,82 \\
\hline 199 & 12 & 0,20 & 0,11 & 4,40 & 14,60 & 7,35 & 58,33 & 1,69 & 178,16 \\
\hline 200 & 10 & 1,00 & 0,09 & 15,25 & 13,90 & 0,00 & 70,00 & 1,80 & 205,00 \\
\hline 257 & 12 & 0,20 & 0,07 & 10,10 & 138,20 & 2,00 & 100,00 & 1,75 & 184,34 \\
\hline 308 & 32 & 0,23 & 0,18 & 10,95 & 6,50 & 13,90 & 37,50 & 1,94 & 179,21 \\
\hline 315 & 15 & 0,15 & 0,07 & 1,10 & 1,85 & 6,50 & 20,00 & 1,93 & 267,05 \\
\hline 318 & 1 & 0,00 & 0,00 & 5,00 & 750,00 & 2,00 & 0,00 & 3,00 & 295,26 \\
\hline 322 & 19 & 0,36 & 0,26 & 1,50 & 20,75 & 2,35 & 52,63 & 1,47 & 111,97 \\
\hline 323 & 26 & 0,24 & 0,17 & 13,70 & 11,95 & 7,20 & 65,38 & 1,46 & 155,79 \\
\hline 352 & 9 & 0,00 & 0,00 & 7,60 & 5,75 & 3,50 & 11,11 & 2,33 & 331,32 \\
\hline 393 & 12 & 0,33 & 1,36 & 0,00 & 32,90 & 0,00 & 58,33 & 1,67 & 232,04 \\
\hline 403 & 15 & 0,36 & 0,08 & 1,50 & 9,25 & 0,00 & 46,67 & 2,20 & 268,16 \\
\hline 409 & 5 & 0,00 & 0,00 & 6,00 & 42,85 & 0,00 & 100,00 & 2,40 & 461,18 \\
\hline 413 & 16 & 0,45 & 0,39 & 0,00 & 126,50 & 0,00 & 62,50 & 1,50 & 288,42 \\
\hline 414 & 5 & 0,67 & 0,04 & 0,00 & 33,75 & 0,00 & 20,00 & 2,60 & 498,08 \\
\hline 485 & 11 & 0,57 & 0,15 & 7,00 & 6,05 & 0,50 & 90,91 & 2,27 & 388,42 \\
\hline 508 & 1 & 0,00 & 0,00 & 3,00 & 300,00 & 1,00 & 0,00 & 2,00 & 721,05 \\
\hline 531 & 18 & 0,13 & 0,10 & 3,75 & 19,90 & 0,00 & 83,33 & 2,67 & 259,47 \\
\hline 547 & 10 & 0,00 & 0,06 & 3,10 & 19,20 & 0,00 & 50,00 & 2,67 & 325,13 \\
\hline 553 & 28 & 0,56 & 0,49 & 10,10 & 11,55 & 3,10 & 92,31 & 1,46 & 135,68 \\
\hline 561 & 17 & 0,13 & 0,05 & 12,25 & 3,70 & 7,75 & 29,41 & 1,63 & 165,00 \\
\hline 572 & 20 & 0,18 & 0,12 & 21,35 & 95,05 & 13,00 & 50,00 & 1,40 & 142,30 \\
\hline 580 & 10 & 0,25 & 0,04 & 2,50 & 65,30 & 0,00 & 70,00 & 2,33 & 179,49 \\
\hline 608 & 17 & 0,31 & 0,23 & 7,00 & 24,60 & 1,30 & 100,00 & 2,18 & 212,37 \\
\hline
\end{tabular}


Anexo D.5. Valores (ou estados) mensurados das 60 microbacias estudadas, com as variáveis sobre as métricas de canal nas estações chuvosas

\begin{tabular}{cccccccccc}
\hline ID & NU & PC & RP & QT & VE & PF & UB & VM & LM \\
\hline 615 & 25 & 0,47 & 0,82 & 14,50 & 20,50 & 3,50 & 44,00 & 1,00 & 193,16 \\
616 & 14 & 0,27 & 0,19 & 3,00 & 10,70 & 0,00 & 35,71 & 1,29 & 229,62 \\
619 & 20 & 0,43 & 0,92 & 0,00 & 26,50 & 0,00 & 10,00 & 1,25 & 144,08 \\
620 & 19 & 0,58 & 2,06 & 1,00 & 55,10 & 11,10 & 10,53 & - & 221,82 \\
632 & 18 & 0,29 & 0,46 & 3,00 & 35,50 & 0,00 & 55,56 & - & 191,31 \\
634 & 21 & 0,05 & 0,24 & 46,75 & 0,25 & - & - & - & 124,92 \\
635 & 9 & 0,29 & 0,05 & 20,75 & 17,25 & 1,70 & 77,78 & 1,56 & 184,74 \\
648 & 20 & 0,54 & 0,22 & 12,25 & 6,15 & 51,85 & 95,00 & 1,65 & 275,54 \\
652 & 31 & 0,41 & 0,64 & 9,50 & 8,25 & 0,75 & 35,29 & 1,12 & 113,97 \\
\hline
\end{tabular}

Anexo D.5. Valores (ou estados) mensurados das 60 microbacias estudadas, com as variáveis sobre as métricas de canal nas estações secas

\begin{tabular}{|c|c|c|c|c|c|c|c|c|c|}
\hline ID & $\mathrm{NU}$ & $\mathrm{PC}$ & $\mathrm{RP}$ & QT & VE & PF & UB & VM & LM \\
\hline 1 & 11 & 0,57 & 0,40 & 0,25 & 78,50 & 0,00 & 18,18 & 1,64 & 202,97 \\
\hline 2 & 11 & 0,00 & 0,00 & 7,75 & 6,45 & 4,50 & 100,00 & 2,42 & 130,26 \\
\hline 3 & 16 & 0,33 & 0,37 & 2,30 & 22,60 & 18,10 & 68,75 & 2,33 & 325,27 \\
\hline 8 & 10 & 0,25 & 0,16 & 3,00 & 20,60 & 10,75 & 70,00 & 2,50 & 327,76 \\
\hline 15 & 23 & 0,21 & 0,13 & 14,40 & 16,25 & 8,15 & 86,96 & 2,13 & 124,87 \\
\hline 20 & 3 & 0,50 & 0,00 & 2,00 & 89,75 & 3,00 & 66,67 & 1,67 & 120,00 \\
\hline 43 & 10 & 0,00 & 0,00 & 10,50 & 16,60 & 4,00 & 70,00 & 2,20 & 218,16 \\
\hline 44 & 17 & 0,55 & 0,50 & 2,90 & 15,35 & 13,00 & 70,59 & 2,07 & 230,26 \\
\hline 59 & 13 & 0,44 & 0,18 & 0,00 & 97,20 & 22,00 & 23,08 & 2,00 & 204,36 \\
\hline 60 & 15 & 0,36 & 0,39 & 1,10 & 55,50 & 48,00 & 20,00 & 1,27 & 165,05 \\
\hline 75 & 10 & 0,11 & 0,17 & 3,20 & 24,65 & 88,60 & 50,00 & 1,82 & 504,08 \\
\hline 76 & 13 & 0,30 & 0,23 & 4,60 & 9,15 & 4,95 & 15,38 & 1,36 & 231,45 \\
\hline 77 & 15 & 0,36 & 0,14 & 0,70 & 113,75 & 5,25 & 13,33 & 1,40 & 206,18 \\
\hline 83 & 4 & 0,00 & 0,00 & 0,00 & 28,50 & 0,00 & 0,00 & 2,00 & 326,84 \\
\hline 85 & 14 & 0,27 & 0,07 & 10,25 & 16,70 & 17,15 & 71,43 & 2,00 & 332,76 \\
\hline 87 & 16 & 0,33 & 2,00 & 0,00 & 76,70 & 5,95 & 25,00 & 1,29 & 126,18 \\
\hline 88 & 11 & 0,22 & 0,49 & 0,45 & 155,50 & 0,00 & 18,18 & 1,09 & 237,11 \\
\hline 120 & 16 & 0,14 & 0,09 & 4,00 & 36,15 & 3,60 & 75,00 & 2,13 & 213,83 \\
\hline 137 & 12 & 0,71 & 3,36 & 1,35 & 101,25 & 0,00 & 66,67 & 1,00 & 176,32 \\
\hline 139 & 3 & 0,00 & 0,00 & 5,50 & 10,30 & 2,50 & 33,33 & 2,20 & 157,63 \\
\hline 140 & 7 & 0,75 & 1,65 & 0,00 & 62,75 & 44,00 & 0,00 & 0,57 & 252,84 \\
\hline 142 & 15 & 0,36 & 0,48 & 2,79 & 28,40 & 0,50 & 46,67 & 1,53 & 166,18 \\
\hline 150 & 7 & 0,00 & 0,00 & 8,00 & 23,50 & 8,25 & 14,29 & 2,00 & 185,26 \\
\hline 171 & 13 & 0,18 & 0,04 & 9,45 & 8,85 & 9,75 & 92,31 & 2,31 & 138,82 \\
\hline 173 & 10 & 0,25 & 0,01 & 2,55 & 37,95 & 6,85 & 70,00 & 1,64 & 119,10 \\
\hline 174 & 21 & 0,31 & 0,41 & 10,55 & 12,45 & 23,90 & 61,90 & 1,52 & 150,38 \\
\hline 188 & 12 & 0,20 & 1,01 & 0,00 & 68,25 & 111,75 & 33,33 & 3,00 & 348,33 \\
\hline 199 & 19 & 0,12 & 0,07 & 7,80 & 9,10 & 16,15 & 42,11 & 1,53 & 161,58 \\
\hline 200 & 10 & 0,43 & 0,14 & 7,85 & 7,73 & 9,23 & 40,00 & 1,44 & 117,11 \\
\hline 257 & 16 & 0,60 & 0,30 & 16,00 & 2,60 & 6,50 & 75,00 & 1,67 & 165,53 \\
\hline 315 & 16 & 0,78 & 0,97 & 3,85 & 1,10 & 62,33 & 12,50 & 1,44 & 209,34 \\
\hline
\end{tabular}


Anexo D.5. Valores (ou estados) mensurados das 60 microbacias estudadas, com as variáveis sobre as métricas de canal nas estações secas

\begin{tabular}{|c|c|c|c|c|c|c|c|c|c|}
\hline ID & $\mathrm{NU}$ & $\mathrm{PC}$ & $\mathrm{RP}$ & QT & $\mathrm{VE}$ & PF & UB & $\mathrm{VM}$ & LM \\
\hline 318 & 10 & 0,00 & 0,00 & 1,75 & 0,75 & 3,65 & 10,00 & 2,00 & 200,95 \\
\hline 322 & 16 & 0,23 & 0,44 & 1,90 & 34,70 & 17,75 & 50,00 & 1,38 & 106,53 \\
\hline 323 & 23 & 0,28 & 0,16 & 3,20 & 7,55 & 14,00 & 21,74 & 1,44 & 141,97 \\
\hline 352 & 5 & 0,00 & 0,00 & 4,45 & 0,20 & 6,95 & 0,00 & 2,40 & 300,16 \\
\hline 393 & 12 & 0,33 & 0,24 & 0,95 & 58,70 & 5,00 & 33,33 & 1,25 & 178,21 \\
\hline 403 & 19 & 0,27 & 0,25 & 0,85 & 11,30 & 0,00 & 57,89 & 2,11 & 230,79 \\
\hline 409 & 4 & 0,00 & 0,00 & 7,00 & 26,50 & 7,00 & 0,00 & 2,00 & 150,54 \\
\hline 413 & 13 & 0,18 & 0,12 & 0,10 & 131,75 & 25,00 & 53,85 & 1,62 & 267,63 \\
\hline 414 & 10 & 0,25 & 0,04 & 0,00 & 36,60 & 0,00 & 30,00 & 2,30 & 232,63 \\
\hline 485 & 17 & 0,42 & 0,25 & 16,30 & 19,35 & 9,10 & 41,18 & 1,94 & 277,22 \\
\hline 508 & 19 & 0,36 & 0,14 & 0,60 & 82,00 & 0,60 & 10,53 & 1,53 & 167,37 \\
\hline 531 & 20 & 0,18 & 0,49 & 8,75 & 22,15 & 40,95 & 45,00 & 1,45 & 212,24 \\
\hline 547 & 10 & 0,00 & 0,00 & 2,10 & 12,00 & 6,25 & 40,00 & 2,40 & 456,24 \\
\hline 553 & 30 & 0,50 & 0,85 & 13,65 & 11,95 & 25,95 & 73,33 & 1,43 & 125,53 \\
\hline 561 & 13 & 0,44 & 0,09 & 11,25 & 7,60 & 3,65 & 61,54 & 1,77 & 203,57 \\
\hline 572 & 20 & 0,43 & 0,17 & 13,35 & 4,60 & 10,40 & 30,00 & 1,42 & 116,11 \\
\hline 580 & 10 & 0,00 & 0,00 & 2,75 & 15,00 & 0,00 & 70,00 & 2,55 & 162,37 \\
\hline 608 & 23 & 0,35 & 0,57 & 11,70 & 8,40 & 32,25 & 60,87 & 1,12 & 162,24 \\
\hline 615 & 19 & 0,46 & 1,37 & 3,20 & 34,95 & 21,35 & 52,63 & 1,26 & 164,86 \\
\hline 616 & 15 & 0,36 & 0,21 & 1,60 & 6,75 & 3,45 & 33,33 & 1,69 & 176,97 \\
\hline 619 & 18 & 0,64 & 1,05 & 0,25 & 55,05 & 6,50 & 61,11 & 1,33 & 135,26 \\
\hline 620 & 21 & 0,31 & 0,85 & 0,75 & 128,50 & 12,75 & 38,10 & 1,38 & 186,13 \\
\hline 632 & 19 & 0,36 & 1,55 & 1,95 & 35,85 & 3,25 & 47,37 & 1,47 & 151,66 \\
\hline 634 & 14 & 0,08 & 0,07 & 0,00 & 22,45 & 2,25 & 64,29 & 2,21 & 148,55 \\
\hline 635 & - & - & - & - & - & - & - & - & - \\
\hline 648 & 18 & 0,80 & 4,04 & 14,25 & 4,50 & 84,60 & 83,33 & 0,83 & 235,92 \\
\hline 652 & 25 & 0,38 & 0,21 & 19,70 & 14,65 & 20,15 & 64,00 & 1,56 & 126,61 \\
\hline
\end{tabular}

Anexo D.6. Valores (ou estados) mensurados das 60 microbacias estudadas, com as variáveis sobre as métricas de canal nas estações chuvosas

\begin{tabular}{ccccccccccccc}
\hline ID & PM & PX & VP & AC & VC & DS & MS & PA & OV & MV & VV & PU \\
\hline 1 & 17,98 & 110 & 328,25 & 391,99 & 70,50 & 0,55 & 6 & 45,36 & 1 & 1,49 & 0,49 & 5,88 \\
2 & 18,78 & 37 & 69,80 & 184,74 & 34,70 & 0,75 & 6 & 33,33 & 2 & 1,99 & 0,14 & 9,52 \\
3 & 17,74 & 82 & 254,49 & 491,25 & 87,17 & 0,75 & 3 & 11,05 & 2 & 1,90 & 0,96 & 20,11 \\
8 & 17,73 & 84 & 135,46 & 484,93 & 85,96 & 0,77 & 4 & 11,17 & 2 & 2,08 & 0,57 & 11,28 \\
15 & 16,84 & 44 & 78,30 & 190,97 & 32,15 & 0,60 & 6 & 56,43 & 2 & 1,97 & 0,53 & 16,55 \\
20 & 38,14 & 120 & 1145,55 & 295,46 & 112,70 & 0,28 & 8 & 23,46 & 1 & 1,46 & 0,58 & 0,60 \\
43 & 13,80 & 55 & 61,68 & 344,21 & 47,49 & 0,38 & 6 & 80,10 & 2 & 2,05 & 0,20 & 8,00 \\
44 & 13,04 & 53 & 90,27 & 351,91 & 45,90 & 0,75 & 2 & 20,12 & 2 & 1,96 & 0,69 & 25,95 \\
47 & 7,81 & 26 & 22,73 & 422,05 & 32,98 & 0,64 & 6 & 57,38 & 2 & 1,97 & 0,51 & 7,95 \\
59 & 34,84 & 170 & 1465,96 & 418,46 & 145,79 & 0,73 & 8 & 30,81 & 1 & 1,52 & 0,46 & 9,57 \\
60 & 27,58 & 96 & 457,16 & 270,99 & 74,74 & 0,58 & 6 & 55,15 & 1 & 1,28 & 0,39 & 12,90
\end{tabular}


Anexo D.6. Valores (ou estados) mensurados das 60 microbacias estudadas, com as variáveis sobre as métricas de canal nas estações chuvosas

\begin{tabular}{|c|c|c|c|c|c|c|c|c|c|c|c|c|}
\hline ID & PM & PX & VP & $\mathrm{AC}$ & $\mathrm{VC}$ & DS & MS & $\mathrm{PA}$ & $\mathrm{OV}$ & MV & VV & $\mathrm{PU}$ \\
\hline 75 & 18,96 & 47 & 87,38 & 373,85 & 70,87 & 0,25 & 6 & 85,31 & 2 & 1,64 & 0,43 & 11,39 \\
\hline 76 & 9,09 & 46 & 63,23 & 475,09 & 43,17 & 0,39 & 6 & 87,25 & 2 & 1,60 & 0,30 & 8,63 \\
\hline 77 & 29,38 & 130 & 708,45 & 414,53 & 121,77 & 0,47 & 8 & 33,99 & 1 & 1,30 & 0,40 & 8,99 \\
\hline 83 & 14,76 & 151 & 232,01 & 539,61 & 79,64 & 0,37 & 6 & 85,64 & 2 & 1,70 & 0,35 & 2,63 \\
\hline 85 & 19,42 & 66 & 125,92 & 528,46 & 102,61 & 0,79 & 6 & 32,18 & 2 & 1,91 & 0,42 & 10,89 \\
\hline 87 & 33,69 & 97 & 454,44 & 441,71 & 148,79 & 0,62 & 6 & 54,17 & 1 & 1,49 & 0,69 & 15,05 \\
\hline 88 & 41,06 & 180 & 1724,90 & 518,90 & 213,06 & 0,74 & 6 & 36,87 & 1 & 0,73 & 0,43 & 1,65 \\
\hline 120 & 14,97 & 43 & 53,19 & 309,87 & 46,38 & 0,55 & 6 & 74,87 & 2 & 1,92 & 0,36 & 3,23 \\
\hline 137 & 27,15 & 96 & 437,39 & 165,20 & 44,86 & 0,70 & 6 & 32,69 & 1 & 0,78 & 0,45 & 8,70 \\
\hline 139 & 4,86 & 58 & 22,04 & 344,39 & 16,74 & 0,25 & 6 & 95,05 & 2 & 1,91 & 0,15 & 4,98 \\
\hline 140 & 36,92 & 105 & 896,87 & 471,43 & 174,07 & 0,62 & 10 & 6,09 & 0 & 0,75 & 0,56 & 4,50 \\
\hline 142 & 6,55 & 18 & 8,69 & 350,74 & 22,96 & 0,25 & 6 & 89,06 & 2 & 1,98 & 0,27 & 2,11 \\
\hline 150 & 12,08 & 47 & 49,90 & 420,39 & 50,76 & 0,13 & 6 & 92,89 & 2 & 1,84 & 0,18 & 1,46 \\
\hline 171 & 14,34 & 41 & 68,25 & 235,46 & 33,77 & 0,76 & 6 & 45,03 & 2 & 1,91 & 0,47 & 18,62 \\
\hline 173 & 27,11 & 74 & 191,74 & 238,03 & 64,52 & 0,43 & 6 & 75,88 & 2 & 1,78 & 0,33 & 8,43 \\
\hline 174 & 11,81 & 47 & 104,28 & 295,48 & 34,91 & 0,79 & 1 & 0,00 & 1 & 1,47 & 0,79 & 26,63 \\
\hline 188 & 34,91 & 220 & 2133,99 & 590,72 & 206,23 & 0,50 & 8 & 36,10 & 1 & 1,35 & 0,34 & 3,50 \\
\hline 199 & 12,91 & 47 & 523,88 & 267,24 & 34,51 & 0,81 & 4 & 9,60 & 1 & 1,54 & 0,47 & 8,42 \\
\hline 200 & 5,71 & 24 & 10,12 & 307,50 & 17,56 & 0,15 & 6 & 90,86 & 2 & 1,78 & 0,25 & 4,95 \\
\hline 257 & 18,83 & 50 & 81,49 & 276,51 & 52,07 & 0,50 & 5 & 1,08 & 2 & 1,81 & 0,22 & 15,14 \\
\hline 308 & 7,16 & 25 & 28,78 & 268,82 & 19,24 & 0,72 & 6 & 37,65 & 2 & 1,60 & 0,58 & 22,73 \\
\hline 315 & 11,94 & 48 & 100,04 & 400,58 & 47,82 & 0,68 & 6 & 41,88 & 2 & 1,52 & 0,52 & 20,00 \\
\hline 318 & 3,70 & 10 & 3,69 & 442,89 & 16,40 & 0,18 & 6 & 98,55 & 2 & 2,09 & 0,50 & 3,38 \\
\hline 322 & 14,74 & 59 & 130,89 & 167,96 & 24,76 & 0,71 & 8 & 20,00 & 1 & 1,24 & 0,39 & 12,28 \\
\hline 323 & 6,29 & 34 & 27,70 & 233,68 & 14,69 & 0,70 & 6 & 35,58 & 1 & 1,13 & 0,51 & 19,05 \\
\hline 352 & 3,90 & 19 & 8,03 & 496,97 & 19,39 & 0,27 & 6 & 88,34 & 2 & 1,87 & 0,27 & 8,13 \\
\hline 393 & 45,98 & 125 & 851,45 & 348,06 & 160,05 & 0,73 & 6 & 30,98 & 1 & 1,07 & 0,35 & 8,59 \\
\hline 403 & 11,40 & 66 & 116,93 & 402,24 & 45,84 & 0,71 & 3 & 4,47 & 2 & 1,68 & 0,58 & 12,50 \\
\hline 409 & 3,21 & 14 & 4,67 & 691,78 & 22,18 & 0,16 & 6 & 96,94 & 2 & 2,09 & 0,32 & 3,61 \\
\hline 413 & 42,14 & 91 & 581,04 & 432,63 & 182,29 & 0,65 & 6 & 52,54 & 1 & 1,14 & 0,66 & 15,63 \\
\hline 414 & 9,41 & 50 & 68,15 & 747,12 & 70,30 & 0,72 & 4 & 6,32 & 2 & 2,16 & 0,79 & 10,78 \\
\hline 485 & 23,07 & 82 & 337,11 & 582,63 & 134,43 & 0,60 & 4 & 12,36 & 2 & 1,93 & 0,71 & 12,14 \\
\hline 508 & 5,33 & 20 & 13,47 & 1081,58 & 57,68 & 0,84 & 6 & 98,41 & 2 & 1,86 & 0,36 & 8,79 \\
\hline 531 & 22,86 & 106 & 314,53 & 389,21 & 88,98 & 0,16 & 3 & 7,57 & 2 & 2,26 & 0,65 & 8,99 \\
\hline 547 & 20,11 & 75 & 173,01 & 487,70 & 98,09 & 0,77 & 6 & 46,80 & 2 & 2,32 & 0,62 & 12,81 \\
\hline 553 & 10,84 & 33 & 55,33 & 203,53 & 22,06 & 0,62 & 6 & 33,10 & 1 & 1,25 & 0,45 & 17,32 \\
\hline 561 & 6,19 & 23 & 10,73 & 247,50 & 15,32 & 0,60 & 6 & 66,67 & 2 & 1,61 & 0,32 & 8,70 \\
\hline 572 & 9,35 & 32 & 30,40 & 213,45 & 19,95 & 0,77 & 7 & 14,91 & 1 & 1,28 & 0,33 & 10,53 \\
\hline 580 & 20,81 & 45 & 124,60 & 269,23 & 56,04 & 0,82 & 1 & 17,99 & 2 & 1,92 & 0,58 & 7,94 \\
\hline 608 & 29,38 & 94 & 262,52 & 318,55 & 93,60 & 0,80 & 4 & 13,22 & 2 & 2,02 & 0,38 & 9,69 \\
\hline 615 & 19,82 & 53 & 189,03 & 289,74 & 57,43 & 0,81 & 7 & 11,66 & 0 & 0,56 & 0,51 & 6,02 \\
\hline 616 & 23,54 & 62 & 187,05 & 344,42 & 81,09 & 0,84 & 6 & 45,05 & 2 & 2,51 & 0,47 & 12,36 \\
\hline 619 & 25,07 & 83 & 320,03 & 216,12 & 54,18 & - & 8 & 25,58 & 0 & 0,79 & 0,96 & 12,39 \\
\hline 620 & 36,38 & 97 & 516,45 & 332,72 & 121,03 & 0,90 & 5 & 4,47 & 0 & 0,74 & 0,71 & 6,04 \\
\hline 632 & 32,29 & 85 & 374,30 & 286,96 & 92,67 & 0,90 & 5 & 7,73 & 1 & 0,89 & 0,71 & 14,75 \\
\hline 634 & 21,11 & 91 & 231,66 & 187,38 & 39,55 & 0,90 & 4 & 23,74 & 1 & 0,99 & 0,61 & 10,94 \\
\hline 635 & 18,62 & 78 & 244,90 & 277,11 & 51,61 & 0,67 & 5 & 5,06 & 1 & 1,38 & 0,34 & 10,53 \\
\hline 648 & 17,33 & 82 & 172,67 & 413,31 & 71,63 & 0,79 & 6 & 41,71 & 2 & 1,66 & 0,40 & 17,31 \\
\hline 652 & 15,80 & 85 & 218,19 & 170,96 & 27,01 & 0,85 & 4 & 5,59 & 1 & 0,88 & 0,57 & 4,17 \\
\hline
\end{tabular}


Anexo D.6. Valores (ou estados) mensurados das 60 microbacias estudadas, com as variáveis sobre as métricas de canal nas estações secas

\begin{tabular}{|c|c|c|c|c|c|c|c|c|c|c|c|c|}
\hline ID & $\mathrm{PM}$ & PX & VP & $\mathrm{AC}$ & $\mathrm{VC}$ & DS & MS & PA & $\mathrm{OV}$ & MV & VV & $\mathrm{PU}$ \\
\hline 1 & 9,28 & 49 & 38,65 & 304,46 & 28,24 & 0,67 & 8 & 24,40 & 1 & 0,85 & 0,28 & 0,71 \\
\hline 2 & 13,47 & 50 & 80,11 & 195,39 & 26,33 & 0,71 & 6 & 41,61 & 3 & 2,67 & 0,73 & 4,10 \\
\hline 3 & 16,84 & 113 & 326,75 & 487,91 & 82,18 & 0,76 & 3 & 21,97 & 1 & 2,00 & 1,73 & 24,68 \\
\hline 8 & 16,01 & 76 & 100,70 & 491,64 & 78,73 & 0,78 & 4 & 10,19 & 2 & 2,29 & 0,66 & 13,59 \\
\hline 15 & 20,64 & 52 & 143,94 & 187,30 & 38,66 & 0,74 & 6 & 49,29 & 2 & 1,86 & 0,61 & 21,32 \\
\hline 20 & 32,12 & 105 & 613,80 & 180,00 & 57,82 & 0,67 & 8 & 36,45 & 1 & 0,96 & 0,96 & 14,63 \\
\hline 43 & 15,14 & 38 & 45,46 & 327,24 & 49,55 & 0,55 & 6 & 69,12 & 2 & 2,14 & 0,21 & 6,44 \\
\hline 44 & 10,67 & 53 & 63,48 & 345,39 & 36,86 & 0,82 & 3 & 27,41 & 3 & 2,17 & 1,43 & 30,82 \\
\hline 59 & 11,66 & 158 & 211,33 & 306,54 & 35,73 & 0,67 & 8 & 34,44 & 1 & 1,02 & 0,50 & 4,27 \\
\hline 60 & 10,81 & 58 & 82,51 & 247,58 & 26,77 & 0,64 & 6 & 37,01 & 1 & 0,66 & 0,23 & 7,27 \\
\hline 75 & 8,50 & 34 & 35,85 & 756,12 & 64,23 & 0,34 & 6 & 77,50 & 2 & 1,69 & 0,31 & 8,29 \\
\hline 76 & 8,72 & 58 & 55,35 & 347,17 & 30,27 & 0,29 & 6 & 86,73 & 2 & 1,51 & 0,32 & 12,25 \\
\hline 77 & 13,21 & 60 & 139,22 & 309,28 & 40,86 & 0,43 & 8 & 36,90 & 1 & 0,89 & 0,13 & 6,55 \\
\hline 83 & 5,46 & 147 & 112,91 & 490,26 & 26,79 & 0,24 & 6 & 91,79 & 2 & 1,76 & 0,23 & 5,79 \\
\hline 85 & 14,48 & 47 & 85,64 & 499,14 & 72,27 & 0,71 & 6 & 42,78 & 2 & 1,77 & 0,46 & 14,14 \\
\hline 87 & 19,89 & 71 & 404,05 & 189,28 & 37,65 & 0,71 & 6 & 33,06 & 0 & 0,39 & 0,29 & 0,00 \\
\hline 88 & 28,38 & 170 & 1103,14 & 355,66 & 100,95 & 0,54 & 8 & 22,82 & 0 & 0,24 & 0,18 & 0,00 \\
\hline 120 & 15,99 & 46 & 78,12 & 320,74 & 51,30 & 0,69 & 6 & 47,59 & 2 & 1,86 & 0,35 & 5,43 \\
\hline 137 & 35,61 & 101 & 631,85 & 264,47 & 94,18 & 0,54 & 8 & 25,00 & 0 & 0,16 & 0,18 & 0,00 \\
\hline 139 & 4,18 & 19 & 5,76 & 236,45 & 9,89 & 0,28 & 6 & 94,83 & 2 & 1,90 & 0,16 & 2,31 \\
\hline 140 & 23,33 & 100 & 747,82 & 379,26 & 88,49 & 0,62 & 7 & 3,45 & 0 & 0,31 & 0,22 & 17,02 \\
\hline 142 & 18,77 & 82 & 424,40 & 249,28 & 46,78 & 0,41 & 6 & 72,73 & 1 & 1,34 & 0,49 & 15,38 \\
\hline 150 & 9,87 & 45 & 30,29 & 277,89 & 27,43 & 0,32 & 6 & 87,10 & 1 & 0,94 & 0,19 & 6,63 \\
\hline 171 & 11,97 & 43 & 85,94 & 208,22 & 24,92 & 0,82 & 4 & 24,49 & 2 & 1,94 & 1,06 & 16,67 \\
\hline 173 & 15,84 & 55 & 151,54 & 178,65 & 28,30 & 0,60 & 6 & 45,80 & 1 & 0,98 & 0,26 & 11,90 \\
\hline 174 & 8,49 & 27 & 40,37 & 225,58 & 19,15 & 0,77 & 1 & 0,00 & 1 & 1,20 & 0,16 & 15,69 \\
\hline 188 & 30,98 & 225 & 1706,53 & 522,50 & 161,87 & 0,62 & 8 & 17,59 & 1 & 1,03 & 0,21 & 6,08 \\
\hline 199 & 10,12 & 45 & 57,41 & 242,37 & 24,52 & 0,77 & 4 & 7,30 & 1 & 1,43 & 0,35 & 13,45 \\
\hline 200 & 5,02 & 12 & 6,62 & 175,66 & 8,82 & 0,67 & 6 & 45,45 & 1 & 0,78 & 0,18 & 8,82 \\
\hline 257 & 13,29 & 42 & 69,72 & 248,29 & 33,00 & 0,53 & 10 & 19,58 & 2 & 1,72 & 0,32 & 21,58 \\
\hline 315 & 7,91 & 31 & 53,30 & 314,01 & 24,84 & 0,81 & 6 & 23,03 & 1 & 0,63 & 0,23 & 24,11 \\
\hline 318 & 1,80 & 7 & 2,27 & 301,42 & 5,43 & 0,43 & 6 & 86,75 & 1 & 0,78 & 0,17 & 20,90 \\
\hline 322 & 11,59 & 45 & 76,67 & 159,79 & 18,52 & 0,76 & 10 & 9,52 & 1 & 1,06 & 0,29 & 5,32 \\
\hline 323 & 5,57 & 25 & 21,34 & 212,96 & 11,85 & 0,82 & 6 & 26,09 & 1 & 0,86 & 0,55 & 8,85 \\
\hline 352 & 3,06 & 11 & 5,48 & 450,24 & 13,79 & 0,40 & 6 & 84,52 & 1 & 0,83 & 0,36 & 18,67 \\
\hline 393 & 25,67 & 79 & 436,07 & 267,31 & 68,63 & 0,72 & 7 & 14,29 & 0 & 0,46 & 0,25 & 7,06 \\
\hline 403 & 8,13 & 40 & 55,76 & 346,18 & 28,15 & 0,79 & 4 & 5,88 & 1 & 1,04 & 0,58 & 12,69 \\
\hline 409 & 7,20 & 22 & 19,72 & 225,81 & 16,26 & 0,54 & 6 & 54,97 & 2 & 1,86 & 0,24 & 11,41 \\
\hline 413 & 21,99 & 89 & 370,41 & 401,45 & 88,29 & 0,68 & 6 & 43,11 & 1 & 0,83 & 0,39 & 7,30 \\
\hline 414 & 5,99 & 19 & 17,08 & 348,95 & 20,91 & 0,75 & 4 & 1,31 & 1 & 1,54 & 1,25 & 4,55 \\
\hline 485 & 12,95 & 67 & 184 & 415,83 & 53,84 & 0,75 & 4 & 6,47 & 1 & 1,12 & 0,72 & 14,01 \\
\hline 508 & 8,67 & 25 & 27,58 & 251,05 & 21,76 & 0,61 & 8 & 30,23 & 1 & 0,88 & 0,16 & 5,10 \\
\hline 531 & 11,79 & 70 & 196,75 & 318,36 & 37,54 & 0,85 & 1 & 4,55 & 1 & 1,16 & 0,58 & 19,85 \\
\hline 547 & 5,98 & 34 & 21,00 & 684,36 & 40,91 & 0,41 & 6 & 72,69 & 2 & 1,87 & 0,27 & 17,45 \\
\hline 553 & 8,81 & 44 & 36,80 & 188,29 & 16,58 & 0,77 & 8 & 13,53 & 1 & 0,99 & 0,23 & 5,66 \\
\hline 561 & 5,61 & 49 & 33,74 & 305,35 & 17,15 & 0,48 & 6 & 74,73 & 2 & 1,62 & 0,34 & 12,22 \\
\hline 572 & 5,57 & 19 & 12,15 & 174,17 & 9,70 & 0,78 & 7 & 13,51 & 1 & 0,84 & 0,13 & 1,12 \\
\hline
\end{tabular}


Anexo D.6. Valores (ou estados) mensurados das 60 microbacias estudadas, com as variáveis sobre as métricas de canal nas estações secas

\begin{tabular}{ccccccccccccc}
\hline ID & PM & PX & VP & AC & VC & DS & MS & PA & OV & MV & VV & PU \\
\hline 580 & 18,48 & 40 & 99,30 & 243,55 & 45,00 & 0,81 & 1 & 15,38 & 2 & 1,62 & 0,49 & 17,96 \\
608 & 12,28 & 50 & 116,98 & 243,36 & 29,88 & 0,77 & 8 & 5,39 & 1 & 0,65 & 0,79 & 17,53 \\
615 & 13,01 & 42 & 119,18 & 247,29 & 32,16 & 0,84 & 8 & 5,11 & 0 & 0,36 & 0,69 & 0,00 \\
616 & 17,51 & 72 & 160,91 & 265,46 & 46,48 & 0,78 & 10 & 21,52 & 1 & 1,13 & 0,45 & 5,88 \\
619 & 25,50 & 62 & 283,36 & 202,89 & 51,74 & 0,75 & 8 & 10,48 & 1 & 0,73 & 0,43 & 10,13 \\
620 & 22,99 & 93 & 455,40 & 279,20 & 64,20 & 0,53 & 8 & 7,38 & 1 & 0,80 & 0,38 & 6,67 \\
632 & 25,48 & 61 & 245,29 & 227,49 & 57,96 & 0,79 & 7 & 7,58 & 1 & 0,79 & 0,57 & 0,00 \\
634 & 8,06 & 25 & 21,90 & 222,83 & 17,96 & 0,75 & 5 & 21,74 & 2 & 1,82 & 0,50 & 7,14 \\
635 & - & - & - & - & - & - & - & - & - & - & - & - \\
648 & 12,93 & 77 & 173,30 & 353,88 & 45,74 & 0,69 & 6 & 31,02 & 0 & 0,28 & 0,20 & 83,33 \\
652 & 13,64 & 60 & 153,01 & 189,91 & 25,91 & 0,79 & 4 & 5,04 & 1 & 1,41 & 0,50 & 11,02 \\
\hline
\end{tabular}




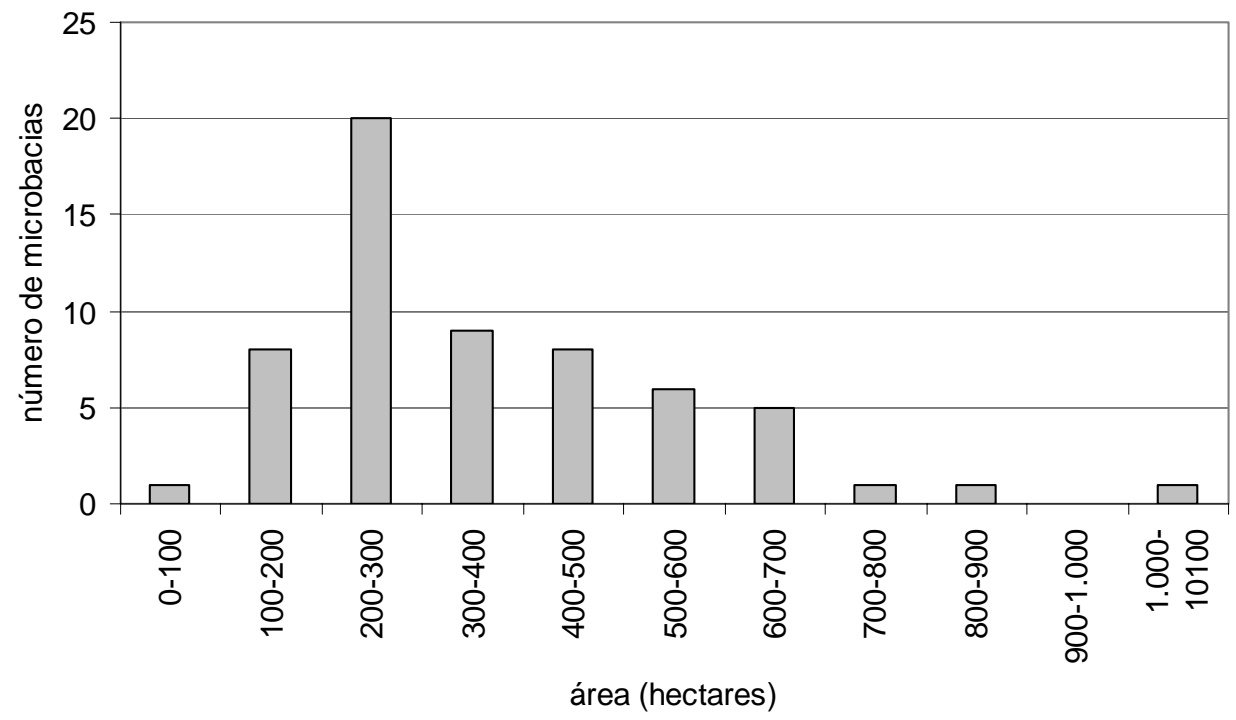

Anexo E.1. Distribuição de freqüência das áreas das 60 microbacias amostradas

Anexo E.2. Resultados da análise de variância sobre a área de 60 microbacias, categorizadas por tipo predominante de uso do solo. SQ = soma de quadrados, $\mathrm{gl}$ = graus de liberdade e $\mathrm{QM}=$ quadrados médios.

Anexo E.3. Resultados da análise de variância sobre a área de 60 microbacias, categorizadas por sub-bacias da Bacia do Rio Corumbataí. SQ = soma de quadrados, $\mathrm{gl}=$ graus de liberdade e $\mathrm{QM}=$ quadrados médios

\begin{tabular}{cccccccc}
\hline \multicolumn{4}{c}{ Cobertura dominante } & \multicolumn{2}{c}{ Erro } \\
SQ & gl & QM & SQ & gl & QM & $F$ & $p$ \\
\hline $15.5120,90$ & 5 & $31.024,18$ & $1.949 .767,0$ & 54 & $36.106,79$ & 0,859 & 0,514 \\
\hline
\end{tabular}




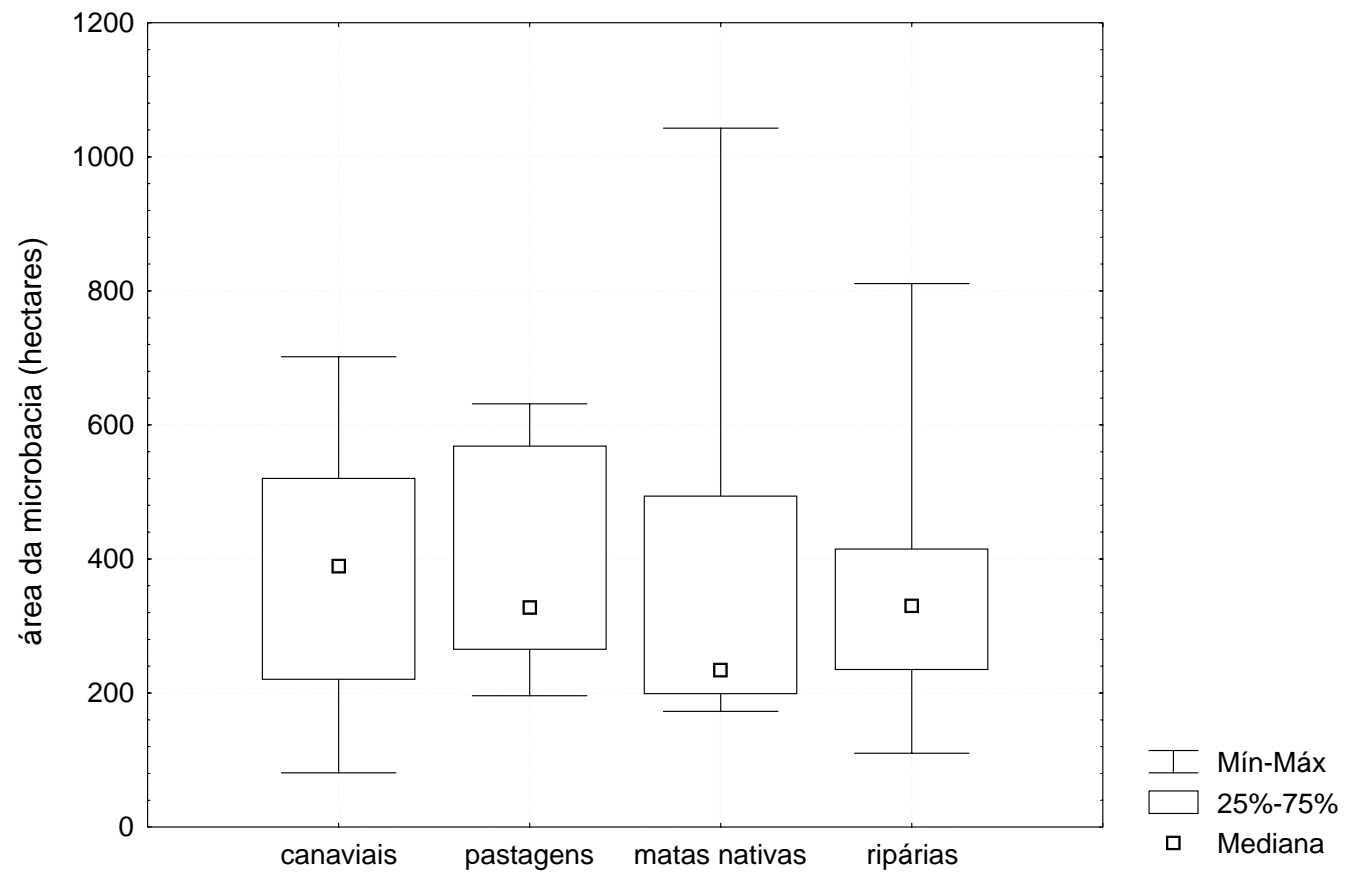

Anexo E.4. Gráfico box-plot mostrando a amplitude, os limites do primeiro e terceiro quartis e mediana das áreas de 60 microbacias, categorizadas pelo uso e cobertura do solo predominante 


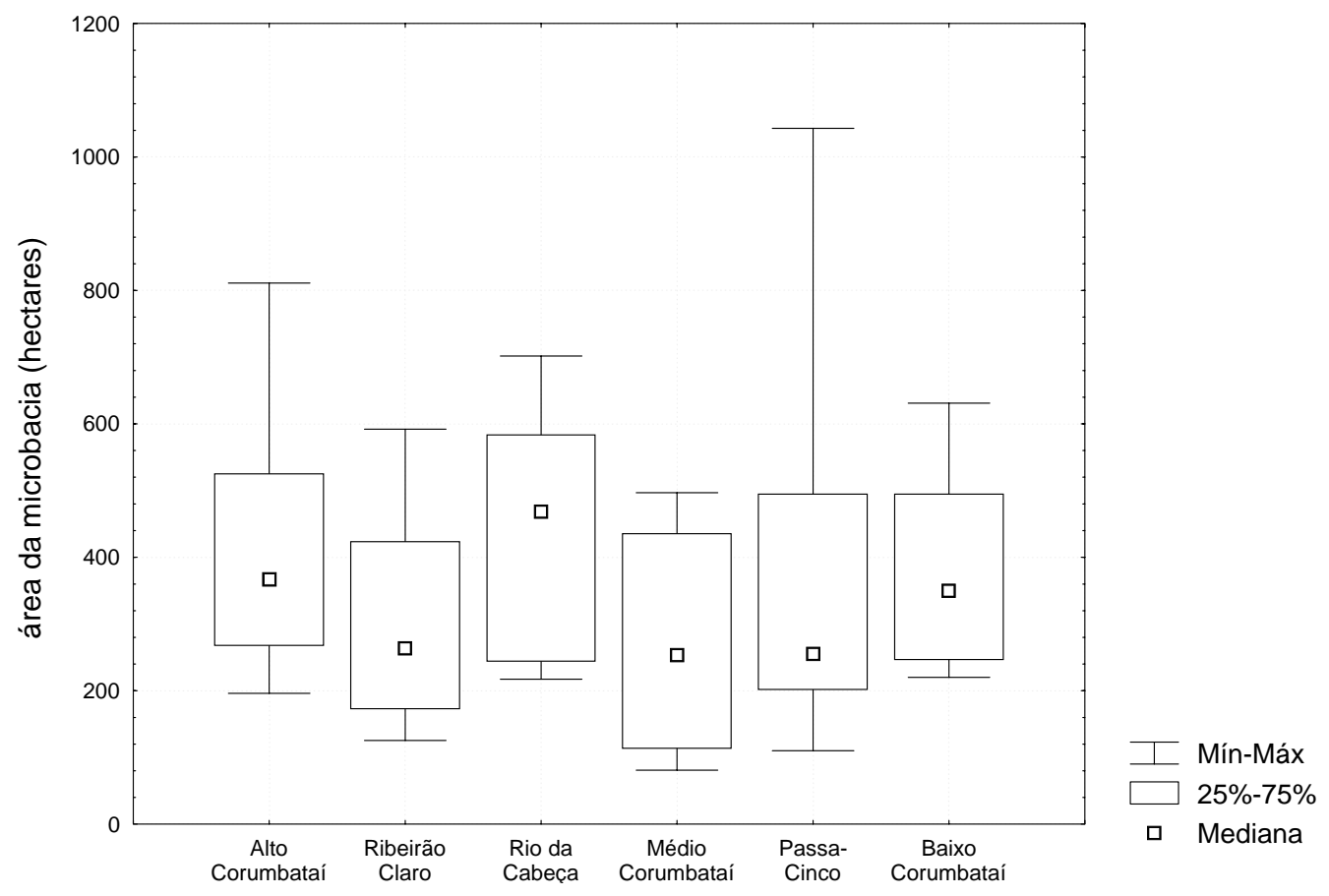

Anexo E.5. Gráfico box-plot mostrando a amplitude, os limites do primeiro e terceiro quartis e mediana das áreas de 60 microbacias, categorizadas por sub-bacias da Bacia do Rio Corumbataí 
Anexo F.1. Coeficientes de correlação de Pearson $(r)$ entre variáveis descritivas medidas de 60 amostras tomadas na estação chuvosa. Valores marcados em negrito são significantes a 0,05 .

\begin{tabular}{ccccccccc}
\hline & $S$ & $F$ & $N$ & $H^{\prime}$ & $E_{H}$ & $D_{r}$ & $B T$ & $G T$ \\
\hline$S$ & 1,00 & $\mathbf{0 , 9 1}$ & $\mathbf{0 , 4 1}$ & $\mathbf{0 , 8 4}$ & $\mathbf{0 , 9 4}$ & $\mathbf{0 , 7 0}$ & $\mathbf{0 , 5 2}$ & $\mathbf{0 , 7 4}$ \\
$F$ & & 1,00 & $\mathbf{0 , 3 5}$ & $\mathbf{0 , 8 3}$ & $\mathbf{0 , 8 8}$ & $\mathbf{0 , 7 2}$ & $\mathbf{0 , 4 4}$ & $\mathbf{0 , 8 6}$ \\
$N$ & & 1,00 & 0,14 & 0,24 & 0,12 & $\mathbf{0 , 5 9}$ & $\mathbf{0 , 3 2}$ \\
$H^{\prime}$ & & & 1,00 & $\mathbf{0 , 9 7}$ & $\mathbf{0 , 9 4}$ & $\mathbf{0 , 3 5}$ & $\mathbf{0 , 6 6}$ \\
$E_{H}$ & & & & 1,00 & $\mathbf{0 , 8 5}$ & $\mathbf{0 , 4 2}$ & $\mathbf{0 , 7 1}$ \\
$D_{r}$ & & & & & 1,00 & $\mathbf{0 , 2 8}$ & $\mathbf{0 , 5 6}$ \\
$B T$ & & & & & & 1,00 & $\mathbf{0 , 3 3}$ \\
$G T$ & & & & & & & 1,00 \\
\hline
\end{tabular}

Anexo F.2. Coeficientes de correlação de Pearson $(r)$ entre variáveis descritivas medidas de 58 amostras tomadas nas estações secas. Valores marcados em negrito são significantes a 0,05 .

\begin{tabular}{ccccccccc}
\hline & $S$ & $F$ & $N$ & $H^{\prime}$ & $E_{H}$ & $D_{r}$ & $B T$ & $G T$ \\
\hline$S$ & 1,00 & $\mathbf{0 , 9 2}$ & $\mathbf{0 , 3 9}$ & $\mathbf{0 , 8 3}$ & $\mathbf{0 , 9 4}$ & $\mathbf{0 , 6 6}$ & $\mathbf{0 , 5 7}$ & $\mathbf{0 , 8 2}$ \\
$F$ & & 1,00 & $\mathbf{0 , 4 0}$ & $\mathbf{0 , 8 2}$ & $\mathbf{0 , 8 8}$ & $\mathbf{0 , 7 1}$ & $\mathbf{0 , 5 8}$ & $\mathbf{0 , 9 0}$ \\
$N$ & & & 1,00 & 0,12 & 0,21 & 0,09 & $\mathbf{0 , 8 6}$ & $\mathbf{0 , 4 2}$ \\
$H^{\prime}$ & & & & 1,00 & $\mathbf{0 , 9 5}$ & $\mathbf{0 , 9 4}$ & $\mathbf{0 , 3 7}$ & $\mathbf{0 , 6 8}$ \\
$E_{H}$ & & & & & 1,00 & $\mathbf{0 , 8 1}$ & $\mathbf{0 , 4 7}$ & $\mathbf{0 , 7 5}$ \\
$D_{r}$ & & & & & & 1,00 & $\mathbf{0 , 2 8}$ & $\mathbf{0 , 5 8}$ \\
$B T$ & & & & & & & 1,00 & $\mathbf{0 , 5 6}$ \\
$G T$ & & & & & & & & 1,00 \\
\hline
\end{tabular}


Anexo G. Ordenação de espécies (código) pelo uso e cobertura do dolo predominantes nas microbacias no total de amostras. Para código das espécies, veja Tabela 20 no corpo do texto. $S=$ número total de espécies e $N=$ número total de indivíduos

\begin{tabular}{ccccccccc}
\hline Posição & Código & canaviais & Código & pastagens & Código & $\begin{array}{c}\text { matas } \\
\text { nativas }\end{array}$ & Código & ripárias \\
\hline 1 & IS & 5511 & SH & 4150 & IS & 1720 & TS & 2816 \\
2 & PC & 2342 & AA & 2007 & TS & 1394 & CO & 1802 \\
3 & TS & 1326 & AF & 1690 & CO & 1036 & IS & 995 \\
4 & AA & 1325 & TS & 1678 & AA & 567 & AP & 618 \\
5 & CO & 1138 & PR & 1404 & PC & 545 & PR & 453 \\
6 & AP & 1119 & CO & 989 & CZ & 490 & PC & 322 \\
7 & PR & 700 & IS & 986 & AP & 374 & AA & 211 \\
8 & HA & 659 & GB & 891 & AE & 265 & HA & 205 \\
9 & BC & 623 & AE & 887 & BC & 208 & CZ & 201 \\
10 & GB & 458 & AP & 762 & HA & 184 & AE & 154 \\
11 & CZ & 415 & CZ & 738 & PR & 114 & SH & 134 \\
12 & AE & 411 & BC & 557 & RQ & 107 & NP & 121 \\
13 & CA & 346 & HA & 442 & DS & 92 & GB & 88 \\
14 & RQ & 216 & SN & 359 & CI & 86 & RQ & 86 \\
15 & MP & 205 & PC & 288 & AF & 49 & BC & 64 \\
16 & GS & 152 & CI & 248 & GB & 49 & GS & 63 \\
17 & BF & 90 & AJ & 243 & MP & 30 & SN & 57 \\
18 & SN & 77 & CS & 234 & GS & 22 & OS & 49 \\
19 & HS & 63 & GS & 212 & PN & 21 & PA & 40 \\
20 & HP & 58 & CA & 203 & AI & 21 & AT & 37 \\
21 & AF & 52 & RQ & 152 & CA & 20 & LJ & 29 \\
22 & OS & 43 & ES & 137 & ES & 16 & CI & 21 \\
23 & CI & 41 & HS & 108 & AS & 10 & BF & 18 \\
24 & CP & 37 & HP & 86 & HL & 10 & CV & 9 \\
25 & PN & 34 & PS & 81 & HP & 10 & HS & 9
\end{tabular}


Anexo G. Ordenação de espécies (código) pelo uso e cobertura do dolo predominantes nas microbacias (CD) no total de amostras. Para código das espécies, veja Tabela 20 no corpo do texto. $S=$ número total de espécies e $N=$ número total de indivíduos

\begin{tabular}{|c|c|c|c|c|c|c|c|c|}
\hline Posição & Código & canaviais & Código & pastagens & Código & $\begin{array}{c}\text { matas } \\
\text { nativas } \\
\end{array}$ & Código & ripárias \\
\hline 26 & $\mathrm{CC}$ & 32 & DS & 61 & PS & 9 & $\mathrm{AF}$ & 8 \\
\hline 27 & ES & 27 & PA & 58 & $\mathrm{BF}$ & 8 & SM & 8 \\
\hline 28 & $\mathrm{CV}$ & 20 & AT & 51 & CG & 6 & HP & 7 \\
\hline 29 & CS & 20 & $\mathrm{BF}$ & 47 & SM & 6 & CG & 5 \\
\hline 30 & SH & 18 & SM & 44 & $\mathrm{CC}$ & 5 & PS & 5 \\
\hline 31 & $\mathrm{HE}$ & 16 & $\mathrm{CV}$ & 36 & SH & 4 & AJ & 3 \\
\hline 32 & $\mathrm{CF}$ & 15 & MP & 32 & $\mathrm{HE}$ & 3 & TR & 3 \\
\hline 33 & SM & 9 & AI & 29 & HS & 3 & AI & 2 \\
\hline 34 & NP & 8 & PN & 27 & SN & 2 & CS & 2 \\
\hline 35 & AS & 5 & LI & 27 & $\mathrm{CV}$ & 1 & $\mathrm{CA}$ & 2 \\
\hline 36 & PS & 5 & $\mathrm{AZ}$ & 16 & $\mathrm{AJ}$ & 1 & $\mathrm{RL}$ & 2 \\
\hline 37 & AJ & 4 & $\mathrm{HL}$ & 14 & LJ & 1 & PN & 0 \\
\hline 38 & $\mathrm{HL}$ & 3 & AR & 10 & CS & 0 & AS & 0 \\
\hline 39 & TR & 2 & NP & 8 & SI & 0 & SI & 0 \\
\hline 40 & AI & 1 & TR & 8 & AT & 0 & AR & 0 \\
\hline 41 & RL & 1 & AS & 7 & AR & 0 & $\mathrm{AZ}$ & 0 \\
\hline 42 & $\mathrm{LJ}$ & 1 & $\mathrm{CP}$ & 7 & $\mathrm{AZ}$ & 0 & $\mathrm{HE}$ & 0 \\
\hline 43 & SI & 0 & CG & 6 & $\mathrm{PA}$ & 0 & SS & 0 \\
\hline 44 & CG & 0 & SI & 4 & OS & 0 & PL & 0 \\
\hline 45 & AT & 0 & ON & 4 & SS & 0 & $\mathrm{CF}$ & 0 \\
\hline 46 & AR & 0 & RL & 3 & PL & 0 & $\mathrm{CC}$ & 0 \\
\hline 47 & $\mathrm{AZ}$ & 0 & OS & 2 & $\mathrm{CF}$ & 0 & HL & 0 \\
\hline 48 & PA & 0 & PL & 2 & NP & 0 & MP & 0 \\
\hline 49 & SS & 0 & $\mathrm{CF}$ & 2 & RL & 0 & LN & 0 \\
\hline 50 & PL & 0 & SS & 1 & LN & 0 & DS & 0 \\
\hline 51 & LN & 0 & $\mathrm{CC}$ & 1 & $\mathrm{CP}$ & 0 & ES & 0 \\
\hline 52 & DS & 0 & LN & 1 & ON & 0 & $\mathrm{CP}$ & 0 \\
\hline$N$ & - & 17.628 & $N$ & 20.040 & $N$ & 7.489 & $N$ & 8.649 \\
\hline$S$ & - & 42 & $S$ & 52 & $S$ & 37 & $S$ & 36 \\
\hline
\end{tabular}


Anexo H. Valores do coeficiente de correlação de Pearson entre variáveis ambientais e descritores de abundância $(N)$ diversidade de espécies $\left(H^{\prime}\right)$ e grupos tróficos (GT). As correlações significativas foram marcadas em negrito

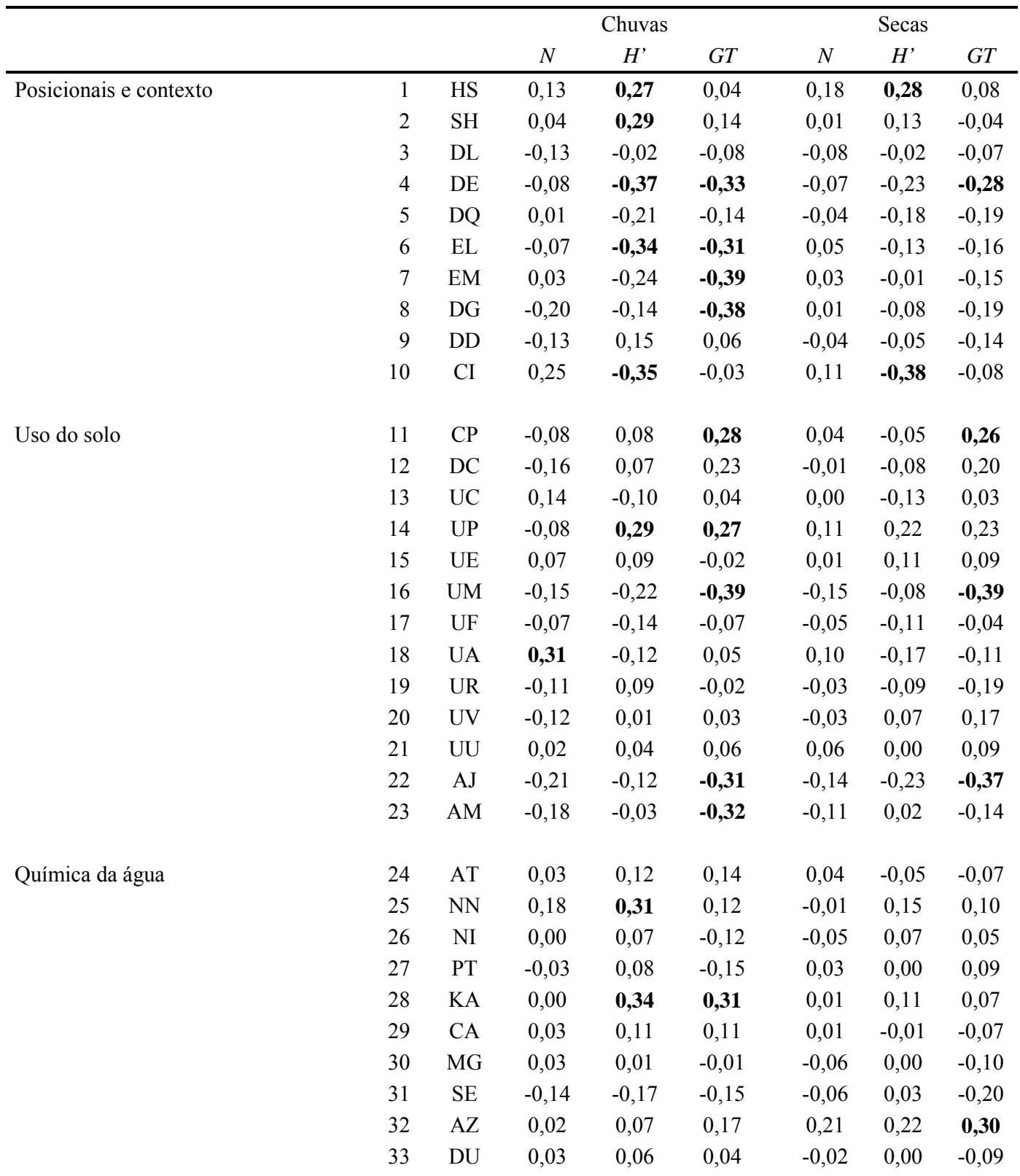


Anexo H. Valores do coeficiente de correlação de Pearson entre variáveis ambientais e descritores de abundância $(N)$ diversidade de espécies $\left(H^{\prime}\right)$ e grupos tróficos $(G T)$. As correlações significativas foram marcadas em negrito

\begin{tabular}{|c|c|c|c|c|c|c|c|c|}
\hline & & & & Chuvas & & & Secas & \\
\hline & & & $N$ & $H^{\prime}$ & $G T$ & $N$ & $H^{\prime}$ & $G T$ \\
\hline & 34 & $\mathrm{CO}$ & 0,06 & 0,12 & 0,32 & 0,18 & 0,16 & 0,24 \\
\hline & 35 & $\mathrm{CR}$ & 0,01 & 0,12 & $-0,10$ & $-0,10$ & $-0,14$ & $-0,16$ \\
\hline & 36 & $\mathrm{TU}$ & $-0,04$ & 0,05 & $-0,16$ & $-0,16$ & $-0,20$ & $-0,30$ \\
\hline & 37 & $\mathrm{CN}$ & 0,07 & 0,08 & 0,10 & $-0,01$ & $-0,02$ & $-0,08$ \\
\hline & 38 & $\mathrm{PH}$ & 0,12 & 0,13 & 0,00 & 0,01 & 0,00 & $-0,02$ \\
\hline & 39 & OD & $-0,07$ & $-0,29$ & $-0,35$ & $-0,14$ & $-0,13$ & $-0,11$ \\
\hline & 40 & SA & $-0,25$ & $-0,07$ & $-0,29$ & 0,17 & 0,29 & 0,23 \\
\hline & 41 & $\mathrm{TG}$ & $-0,08$ & 0,29 & 0,12 & 0,07 & 0,29 & 0,12 \\
\hline Métricas de segmento e canal & 42 & SI & $-0,05$ & $-0,04$ & $-0,12$ & 0,10 & 0,03 & 0,02 \\
\hline & 43 & DRE & 0,03 & $-0,01$ & 0,06 & 0,10 & 0,07 & 0,04 \\
\hline & 44 & $\mathrm{BM}$ & $-0,15$ & $-0,04$ & $-0,17$ & 0,19 & 0,04 & 0,11 \\
\hline & 45 & $\mathrm{AB}$ & $-0,07$ & 0,32 & 0,26 & 0,11 & 0,17 & 0,17 \\
\hline & 46 & LP & 0,15 & 0,42 & 0,44 & $-0,05$ & 0,22 & 0,05 \\
\hline & 47 & $\mathrm{CV}$ & $-0,16$ & $-0,35$ & $-0,41$ & 0,06 & $-0,31$ & $-0,35$ \\
\hline & 48 & AP & $-0,05$ & $-0,27$ & $-0,25$ & $-0,19$ & $-0,36$ & $-0,49$ \\
\hline & 49 & $\mathrm{SO}$ & $-0,09$ & $-0,39$ & $-0,42$ & $-0,21$ & $-0,51$ & $-0,54$ \\
\hline & 50 & IS & $-0,04$ & 0,19 & 0,40 & $-0,14$ & 0,01 & 0,08 \\
\hline & 51 & $\mathrm{NU}$ & 0,02 & 0,07 & 0,17 & $-0,07$ & $-0,09$ & $-0,17$ \\
\hline & 52 & $\mathrm{PC}$ & 0,21 & 0,27 & 0,25 & $-0,07$ & $-0,12$ & $-0,19$ \\
\hline & 53 & $\mathrm{RP}$ & 0,31 & 0,30 & 0,48 & $-0,07$ & $-0,10$ & $-0,18$ \\
\hline & 54 & QT & $-0,04$ & $-0,23$ & $-0,20$ & $-0,13$ & $-0,25$ & $-0,37$ \\
\hline & 55 & VE & $-0,20$ & $-0,11$ & $-0,10$ & 0,18 & 0,47 & 0,53 \\
\hline & 56 & $\mathrm{PF}$ & 0,02 & 0,23 & 0,28 & $-0,11$ & 0,15 & $-0,10$ \\
\hline & 57 & UB & 0,14 & $-0,13$ & $-0,12$ & $-0,07$ & $-0,15$ & $-0,09$ \\
\hline & 58 & VM & 0,02 & 0,22 & 0,19 & $-0,08$ & $-0,13$ & $-0,21$ \\
\hline & 59 & LM & $-0,02$ & 0,10 & $-0,15$ & 0,04 & 0,27 & 0,07 \\
\hline & 60 & $\mathrm{PM}$ & 0,30 & 0,46 & $\mathbf{0 , 6 0}$ & 0,10 & 0,10 & 0,14 \\
\hline & 61 & PX & 0,15 & 0,41 & 0,47 & 0,11 & 0,29 & 0,39 \\
\hline & 62 & VP & 0,12 & 0,29 & 0,41 & 0,15 & 0,33 & 0,40 \\
\hline & 63 & $\mathrm{AC}$ & $-0,02$ & 0,10 & $-0,15$ & 0,04 & 0,27 & 0,08 \\
\hline & 64 & $\mathrm{VC}$ & 0,27 & 0,48 & 0,50 & 0,20 & 0,38 & 0,39 \\
\hline & 65 & DS & 0,07 & 0,09 & 0,11 & $-0,07$ & $-0,12$ & $-0,20$ \\
\hline & 66 & PA & $-0,31$ & $-0,09$ & $-0,08$ & $-0,25$ & $-0,26$ & $-0,28$ \\
\hline & 67 & MV & $-0,11$ & $-0,30$ & $-0,56$ & $-0,08$ & $-0,13$ & $-0,21$ \\
\hline & 68 & VV & 0,18 & 0,25 & 0,10 & $-0,07$ & $-0,12$ & $-0,20$ \\
\hline & 69 & PU & 0,08 & $-0,02$ & $-0,09$ & $-0,12$ & $-0,17$ & $-0,36$ \\
\hline
\end{tabular}


Anexo I.1. Resultados das análises de variância de descritores de abundância $(N)$ e diversidade de espécies ( $\left.H^{\prime}\right)$ e grupos tróficos (GT) sobre variáveis ambientais nominais (código no Anexo C) mensuradas nas estações chuvosas. Os valores significativos foram destacados em negrito $\mathrm{SQ}=$ soma de quadrados, $\mathrm{gl}$ = graus de liberdade e $\mathrm{QM}=$ quadrados médios.

\begin{tabular}{|c|c|c|c|c|c|c|c|c|c|}
\hline \multirow{2}{*}{$\begin{array}{c}\text { Variável } \\
\text { ambien- } \\
\text { tal } \\
\end{array}$} & \multirow{2}{*}{$\begin{array}{l}\text { Variável- } \\
\text { resposta }\end{array}$} & \multicolumn{3}{|c|}{ Efeito da variável ambiental } & \multicolumn{3}{|c|}{ Erro } & \multirow[b]{2}{*}{$F$} & \multirow[b]{2}{*}{$p$} \\
\hline & & SQ & $\mathrm{gl}$ & QM & SQ & $\mathrm{gl}$ & QM & & \\
\hline \multirow[t]{3}{*}{ OR } & $N$ & $1.052 .263,4$ & 7 & $150.323,3$ & $5.666 .592,6$ & 52 & $108.972,9$ & 1,379 & 0,234 \\
\hline & $H^{\prime}$ & 2,9 & 7 & 0,4 & 14,38 & 52 & 0,28 & 1,512 & 0,184 \\
\hline & $G T$ & 10,0 & 7 & 1,4 & 73,97 & 52 & 1,42 & 1,007 & 0,437 \\
\hline \multirow[t]{3}{*}{ ER } & $N$ & $1.390 .630,9$ & 8 & $173.828,9$ & $5.328 .225,1$ & 51 & $104.475,0$ & 1,664 & 0,130 \\
\hline & $H^{\prime}$ & 6,3 & 8 & 0,8 & 10,99 & 51 & 0,22 & 3,665 & 0,002 \\
\hline & $G T$ & 16,0 & 8 & 2,0 & 68,04 & 51 & 1,33 & 1,495 & 0,182 \\
\hline \multirow[t]{3}{*}{ TS } & $N$ & $407.506,1$ & 3 & $135.835,4$ & $3.271 .191,9$ & 28 & $116.828,3$ & 1,163 & 0,341 \\
\hline & $H^{\prime}$ & 1,4 & 3 & 0,5 & 6,53 & 28 & 0,23 & 1,957 & 0,143 \\
\hline & $G T$ & 8,9 & 3 & 3,0 & 37,93 & 28 & 1,35 & 2,200 & 0,110 \\
\hline \multirow[t]{3}{*}{$\mathrm{CV}$} & $N$ & $243.326,6$ & 4 & $60.831,6$ & $6.475 .529,4$ & 55 & $117.736,9$ & 0,517 & 0,724 \\
\hline & $H^{\prime}$ & 3,2 & 4 & 0,8 & 14,08 & 55 & 0,26 & 3,145 & 0,021 \\
\hline & $G T$ & 19,1 & 4 & 4,8 & 64,91 & 55 & 1,18 & 4,043 & 0,006 \\
\hline \multirow[t]{3}{*}{ MS } & $N$ & $1.408 .701,1$ & 8 & $176.087,6$ & $5.310 .154,9$ & 51 & $104.120,7$ & 1,691 & 0,123 \\
\hline & $H^{\prime}$ & 1,3 & 8 & 0,2 & 15,98 & 51 & 0,31 & 0,528 & 0,830 \\
\hline & $G T$ & 10,8 & 8 & 1,3 & 73,21 & 51 & 1,44 & 0,939 & 0,493 \\
\hline \multirow[t]{3}{*}{$\mathrm{OV}$} & $N$ & $248.757,8$ & 2 & $124.378,9$ & $6.470 .098,7$ & 57 & $113.510,5$ & 1,096 & 0,341 \\
\hline & $H^{\prime}$ & 1,5 & 2 & 0,7 & 15,84 & 57 & 0,28 & 2,632 & 0,081 \\
\hline & $G T$ & 29,8 & 2 & 14,9 & 54,24 & 57 & 0,95 & 15,639 & 0,000 \\
\hline
\end{tabular}

Observação: Testes exploratórios. Não foram verificadas as premissas de normalidade dos dados ou homogeneidade de variâncias. Alguns testes são largamente desbalanceados entre os grupos 
Anexo I.2. Resultados das análises de variância de descritores de abundância $(N)$ e diversidade de espécies ( $\left.H^{\prime}\right)$ e grupos tróficos (GT) sobre variáveis ambientais nominais (código no Anexo C) mensuradas nas estações secas. Os valores significativos foram destacados em negrito $\mathrm{SQ}=$ soma de quadrados, $\mathrm{gl}$ = graus de liberdade e $\mathrm{QM}=$ quadrados médios

\begin{tabular}{|c|c|c|c|c|c|c|c|c|c|}
\hline \multirow{2}{*}{$\begin{array}{c}\text { Variável } \\
\text { ambien- } \\
\text { tal } \\
\end{array}$} & \multirow{2}{*}{$\begin{array}{l}\text { Variável- } \\
\text { resposta }\end{array}$} & \multicolumn{3}{|c|}{ Efeito da variável ambiental } & \multicolumn{3}{|c|}{ Erro } & \multirow[b]{2}{*}{$F$} & \multirow[b]{2}{*}{$p$} \\
\hline & & SQ & $\mathrm{gl}$ & QM & SQ & $\mathrm{gl}$ & QM & & \\
\hline \multirow[t]{3}{*}{ OR } & $N$ & $3.556 .320,0$ & 7 & $508.045,7$ & 23.920.839, & 50 & $478.416,8$ & 1,062 & 0,402 \\
\hline & $H^{\prime}$ & 2,1 & 7 & 0,3 & 14,2 & 50 & 0,3 & 1,050 & 0,409 \\
\hline & $G T$ & 7,7 & 7 & 1,1 & 77,8 & 50 & 1,6 & 0,710 & 0,664 \\
\hline \multirow[t]{3}{*}{ ER } & $N$ & $5.878 .417,4$ & 8 & $734.802,2$ & 21.598.742, & 49 & $440.790,7$ & 1,667 & 0,131 \\
\hline & $H^{\prime}$ & 5,0 & 8 & 0,6 & 11,3 & 49 & 0,2 & 2,704 & 0,015 \\
\hline & $G T$ & 7,9 & 8 & 1,0 & 77,6 & 49 & 1,6 & 0,625 & 0,753 \\
\hline \multirow[t]{3}{*}{ TS } & $N$ & $4.911 .966,2$ & 21 & $233.903,2$ & 22.565.193, & 36 & $626.810,9$ & 0,373 & 0,990 \\
\hline & $H^{\prime}$ & 8,8 & 21 & 0,4 & 7,5 & 36 & 0,2 & 2,016 & 0,031 \\
\hline & $G T$ & 37,2 & 21 & 1,8 & 48,3 & 36 & 1,3 & 1,321 & 0,226 \\
\hline \multirow[t]{3}{*}{$\mathrm{CV}$} & $N$ & $1.361 .525,8$ & 4 & $340.381,4$ & 26.115.634, & 53 & $492.747,8$ & 0,691 & 0,602 \\
\hline & $H^{\prime}$ & 3,5 & 4 & 0,9 & 12,8 & 53 & 0,2 & 3,607 & 0,011 \\
\hline & $G T$ & 17,9 & 4 & 4,5 & 67,6 & 53 & 1,3 & 3,512 & 0,013 \\
\hline \multirow[t]{3}{*}{ MS } & $N$ & $6.356 .800,3$ & 7 & $908.114,3$ & 20.981.783, & 49 & $428.199,7$ & 2,121 & 0,059 \\
\hline & $H^{\prime}$ & 0,9 & 7 & 0,1 & 15,2 & 49 & 0,3 & 0,413 & 0,890 \\
\hline & $G T$ & 9,9 & 7 & 1,4 & 72,3 & 49 & 1,5 & 0,961 & 0,470 \\
\hline \multirow[t]{3}{*}{$\mathrm{OV}$} & $N$ & $4.085 .304,7$ & 3 & 1.361.768, & 23.253.279, & 53 & $438.741,1$ & 3,104 & 0,034 \\
\hline & $H^{\prime}$ & 1,8 & 3 & 0,6 & 14,3 & 53 & 0,3 & 2,185 & 0,101 \\
\hline & $G T$ & 14,3 & 3 & 4,8 & 68,0 & 53 & 1,3 & 3,711 & 0,017 \\
\hline
\end{tabular}

Observação: Testes exploratórios. Não foram verificadas as premissas de normalidade dos dados ou homogeneidade de variâncias. Alguns testes são largamente desbalanceados entre os grupos 
Anexo J.1. Resultados das análises de variância $(F)$ sobre os grupos definidos através da análise de agrupamento sobre variáveis ambientais nominais (código no Anexo C. Graus de liberdade para as variáveis ambientais nas chuvas $=56 \mathrm{e}$ nas secas $=53$. Graus de liberdade para as variáveis categóricas (grupos) nas chuvas $=4$ e nas secas $=3$. Foram destacados em negrito os valores de probabilidade menores que $0,05(p<0,05)$

\begin{tabular}{|c|c|c|c|c|c|}
\hline & \multicolumn{3}{|c|}{ Chuvas } & \multicolumn{2}{|c|}{ Secas } \\
\hline & & $F$ & $p$ & $F$ & $p$ \\
\hline 1 & $\mathrm{AR}$ & 2,683 & 0,055 & 1,690 & 0,166 \\
\hline 2 & HS & 3,223 & 0,029 & 3,118 & 0,022 \\
\hline 3 & $\mathrm{SH}$ & 1,282 & 0,290 & 1,484 & 0,220 \\
\hline 4 & DL & 1,264 & 0,296 & 1,365 & 0,259 \\
\hline 5 & DE & 1,875 & 0,144 & 1,299 & 0,282 \\
\hline 6 & DQ & 1,796 & 0,158 & 0,214 & 0,930 \\
\hline 7 & EL & 8,890 & 0,000 & 3,243 & 0,019 \\
\hline 8 & EM & 15,735 & 0,000 & 5,240 & 0,001 \\
\hline 9 & DG & 5,917 & 0,001 & 0,789 & 0,538 \\
\hline 10 & DD & 1,242 & 0,303 & 2,288 & 0,072 \\
\hline 11 & CI & 2,943 & 0,041 & 2,573 & 0,048 \\
\hline 12 & $\mathrm{CP}$ & 3,802 & 0,015 & 2,452 & 0,057 \\
\hline 13 & DC & 3,339 & 0,026 & 2,360 & 0,065 \\
\hline 14 & $\mathrm{UC}$ & 4,161 & 0,010 & 2,658 & 0,043 \\
\hline 15 & UP & 3,425 & 0,023 & 5,400 & 0,001 \\
\hline 16 & UE & 0,798 & 0,500 & 1,531 & 0,206 \\
\hline 17 & UM & 3,152 & 0,032 & 0,729 & 0,576 \\
\hline 18 & UF & 1,334 & 0,273 & 1,010 & 0,411 \\
\hline 19 & UA & 1,915 & 0,138 & 1,430 & 0,237 \\
\hline 20 & UR & 2,232 & 0,094 & 3,427 & 0,015 \\
\hline 21 & UV & 1,180 & 0,326 & 0,456 & 0,768 \\
\hline 22 & UU & 2,252 & 0,092 & 1,559 & 0,199 \\
\hline 23 & $\mathrm{AJ}$ & 3,334 & 0,026 & 2,741 & 0,038 \\
\hline 24 & AM & 8,416 & 0,000 & 2,909 & 0,030 \\
\hline 25 & AT & 3,559 & 0,020 & 2,163 & 0,086 \\
\hline 26 & $\mathrm{NN}$ & 0,167 & 0,918 & 1,039 & 0,396 \\
\hline 27 & NI & 1,621 & 0,195 & 0,140 & 0,966 \\
\hline 28 & $\mathrm{PT}$ & 0,515 & 0,674 & 1,531 & 0,207 \\
\hline 29 & KA & 3,549 & 0,020 & 2,479 & 0,055 \\
\hline 30 & $\mathrm{CA}$ & 3,988 & 0,012 & 2,046 & 0,101 \\
\hline 31 & MG & 2,138 & 0,106 & 1,742 & 0,154 \\
\hline 32 & SE & 0,929 & 0,433 & 0,594 & 0,669 \\
\hline 33 & $\mathrm{AZ}$ & 0,449 & 0,719 & 2,842 & 0,033 \\
\hline 34 & DU & 2,979 & 0,039 & 1,938 & 0,118 \\
\hline
\end{tabular}


Anexo J.1. Resultados das análises de variância $(F)$ sobre os grupos definidos através da análise de agrupamento sobre variáveis ambientais nominais (código no Anexo C. Graus de liberdade para as variáveis ambientais nas chuvas $=56 \mathrm{e}$ nas secas $=53$. Graus de liberdade para as variáveis categóricas (grupos) nas chuvas $=4$ e nas secas $=3$. Foram destacados em negrito os valores de probabilidade menores que $0,05(p<0,05)$

\begin{tabular}{|c|c|c|c|c|c|}
\hline & & \multicolumn{2}{|c|}{ Chuvas } & \multicolumn{2}{|c|}{ Secas } \\
\hline & & $F$ & $p$ & $F$ & $p$ \\
\hline 35 & $\mathrm{CO}$ & 2,121 & 0,108 & 1,732 & 0,157 \\
\hline 36 & CR & 0,463 & 0,709 & 0,860 & 0,494 \\
\hline 37 & TU & 0,457 & 0,714 & 0,198 & 0,938 \\
\hline 38 & $\mathrm{CN}$ & 3,487 & 0,022 & 1,776 & 0,147 \\
\hline 39 & $\mathrm{PH}$ & 0,951 & 0,422 & 0,716 & 0,585 \\
\hline 40 & OD & 2,141 & 0,105 & 3,435 & 0,014 \\
\hline 41 & SA & 2,282 & 0,089 & 1,325 & 0,273 \\
\hline 42 & TG & 0,094 & 0,963 & 2,485 & 0,055 \\
\hline 43 & SI & 2,476 & 0,071 & 0,127 & 0,972 \\
\hline 44 & DRE & 0,917 & 0,439 & 1,376 & 0,255 \\
\hline 45 & $\mathrm{BM}$ & 4,487 & 0,007 & 1,372 & 0,256 \\
\hline 46 & $\mathrm{AB}$ & 0,479 & 0,698 & 1,435 & 0,235 \\
\hline 47 & LP & 3,618 & 0,018 & 1,257 & 0,298 \\
\hline 48 & $\mathrm{AP}$ & 1,341 & 0,270 & 2,277 & 0,073 \\
\hline 49 & SO & 2,220 & 0,096 & 2,922 & 0,029 \\
\hline 50 & IS & 3,786 & 0,015 & 2,350 & 0,066 \\
\hline 51 & NU & 0,422 & 0,738 & 2,165 & 0,086 \\
\hline 52 & $\mathrm{PC}$ & 1,466 & 0,234 & 0,976 & 0,429 \\
\hline 53 & $\mathrm{RP}$ & 3,751 & 0,016 & 0,933 & 0,452 \\
\hline 54 & QT & 1,067 & 0,371 & 1,574 & 0,195 \\
\hline 55 & VE & 0,066 & 0,978 & 7,496 & 0,000 \\
\hline 56 & $\mathrm{PF}$ & 0,774 & 0,513 & 1,339 & 0,268 \\
\hline 57 & UB & 0,125 & 0,945 & 1,084 & 0,374 \\
\hline 58 & VM & 1,058 & 0,374 & 0,923 & 0,458 \\
\hline 59 & LM & 1,889 & 0,142 & 1,666 & 0,172 \\
\hline 60 & PM & 8,411 & 0,000 & 1,288 & 0,287 \\
\hline 61 & $\mathrm{PX}$ & 4,551 & 0,006 & 5,433 & 0,001 \\
\hline 62 & VP & 2,639 & 0,058 & 7,004 & 0,000 \\
\hline 63 & $\mathrm{AC}$ & 1,889 & 0,142 & 1,775 & 0,148 \\
\hline 64 & $\mathrm{VC}$ & 5,094 & 0,003 & 4,541 & 0,003 \\
\hline 65 & DS & 1,729 & 0,172 & 0,969 & 0,432 \\
\hline 66 & $\mathrm{PA}$ & 1,613 & 0,197 & 1,000 & 0,416 \\
\hline 67 & MV & 6,034 & 0,001 & 0,951 & 0,442 \\
\hline 68 & VV & 0,597 & 0,620 & 0,926 & 0,456 \\
\hline 69 & PU & 2,226 & 0,095 & 0,817 & 0,520 \\
\hline
\end{tabular}


Anexo J.2. Matriz de comparação entre os grupos obtidos através da análise de agrupamento nas estações chuvosas, indicando, das variáveis significativas do Anexo J.1., aquelas que são significativamente diferentes entre os grupos. Resultados de testes post hoc de Tukey, com 0,05 de significância

\begin{tabular}{lllll}
\hline & I & II & III & IV \\
\hline I & - & EL, EM, DG, AT, & HS, EM, DG, & EL, EM, IS, AM \\
& & DU, CN, KA, CA, & AM, UP, UC & \\
& & RP, PM, VC, MV, & & \\
& & PX, AM, UC, CP, & \\
& DC. UM, BM, & & \\
& & DC, LP, AJ & & \\
II & - & - & CI, PM, VC, UP & PM, VC \\
III & - & - & - & sem diferenças \\
IV & - & - & - & - \\
\hline
\end{tabular}

Anexo J.3. Matriz de comparação entre os grupos obtidos através da análise de agrupamento nas estações secas, indicando, das variáveis significativas do Anexo J.1., aquelas que são significativamente diferentes entre os grupos. Resultados de testes post hoc de Tukey, com 0,05 de significância

\begin{tabular}{|c|c|c|c|c|c|}
\hline & I & II & III & IV & V \\
\hline I & - & $\begin{array}{l}\text { HS, AM, UC, } \\
\text { UP, UR }\end{array}$ & $\begin{array}{l}\text { EL, EM, AM, } \\
\text { OD, AZ, VE, } \\
\text { PX, VC }\end{array}$ & $\begin{array}{l}\text { EM, AZ, AJ, } \\
\text { VP, VE, PX }\end{array}$ & sem diferenças \\
\hline II & - & - & $\begin{array}{lll}\text { CI, VP. } & \text { UP, } \\
\text { OD, } & \text { SO, VE, } \\
\text { VC } & \end{array}$ & UP, SO & UR \\
\hline III & - & - & - & sem diferenças & $\begin{array}{l}\text { AZ, SO, VP, } \\
\text { VE, PX, VC }\end{array}$ \\
\hline IV & - & - & - & - & $\begin{array}{l}\text { AZ, SO, VP, } \\
\text { PX }\end{array}$ \\
\hline V & - & - & - & - & - \\
\hline
\end{tabular}




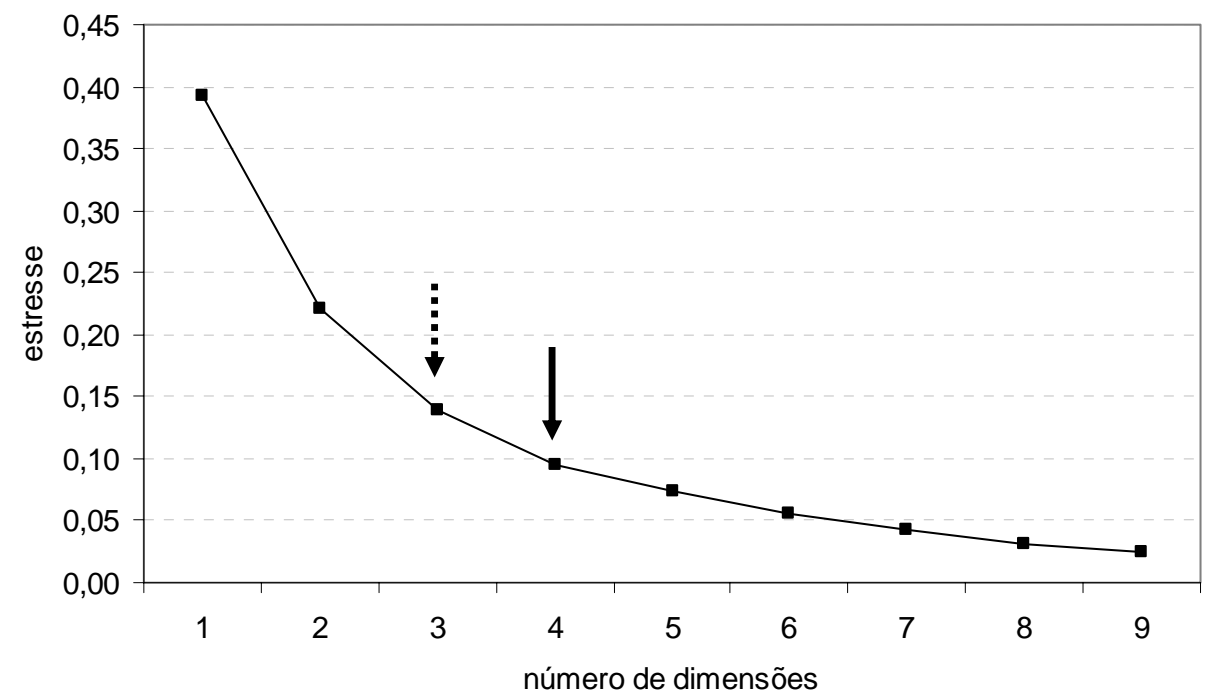

Anexo K.1. Gráfico de estresse em função do número de dimensões de ordenação das 60 amostras de peixes de riachos tomadas nas estações chuvosas. A seta cheia indica o número de dimensões ideal para a ordenação, e a seta pontilhada o valor escolhido para análise neste trabalho: três dimensões

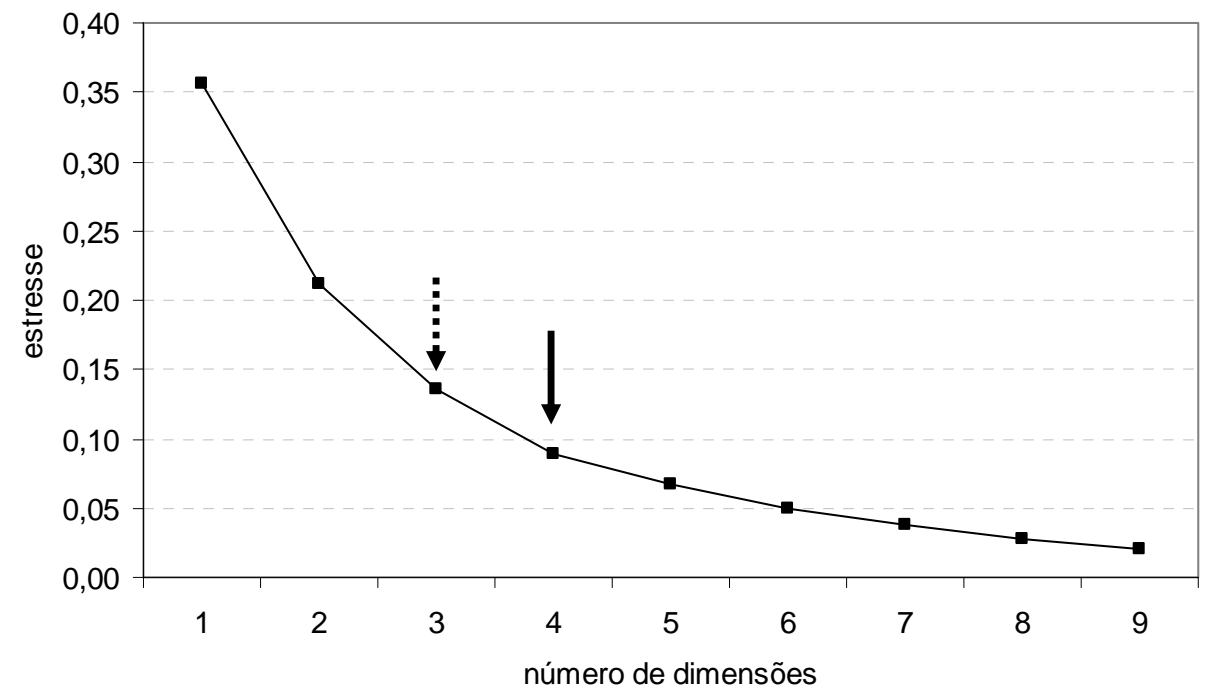

Anexo K.2. Gráfico de estresse em função do número de dimensões de ordenação das 58 amostras de peixes de riachos tomadas nas estações secas. A seta cheia indica o número de dimensões ideal para a ordenação, e a seta pontilhada o valor escolhido para análise neste trabalho: três dimensões 
Anexo L.1. Valores das correlações $(r)$ das variáveis descritivas do ambiente tomadas nas estações chuvosas com as dimensões utilizadas na técnica de NMDS. Tamanho da amostra: 60. Os valores em negrito indicam correlações significantes ao nível de $0,05(p<0,05)$

\begin{tabular}{|c|c|c|c|c|c|c|c|}
\hline \multirow[b]{2}{*}{ \# } & \multirow[b]{2}{*}{ cód } & \multicolumn{2}{|c|}{ Dimensão 1} & \multicolumn{2}{|c|}{ Dimensão 2} & \multicolumn{2}{|c|}{ Dimensão 3} \\
\hline & & $r$ & $p$ & $r$ & $p$ & $r$ & $p$ \\
\hline 1 & HS & $-0,190$ & 0,146 & $-0,376$ & 0,003 & $-0,139$ & 0,291 \\
\hline 2 & $\mathrm{SH}$ & $-0,014$ & 0,917 & $-0,254$ & 0,050 & $-0,106$ & 0,418 \\
\hline 3 & DL & 0,015 & 0,909 & 0,157 & 0,232 & $-0,153$ & 0,245 \\
\hline 4 & $\mathrm{DE}$ & $-0,295$ & 0,022 & 0,082 & 0,533 & $-0,088$ & 0,503 \\
\hline 5 & DQ & $-0,037$ & 0,780 & 0,071 & 0,592 & $-0,080$ & 0,542 \\
\hline 6 & EL & $-0,615$ & 0,000 & $-0,159$ & 0,224 & $-0,042$ & 0,750 \\
\hline 7 & EM & $-0,643$ & 0,000 & $-0,235$ & 0,071 & 0,036 & 0,783 \\
\hline 8 & DG & $-0,392$ & 0,002 & $-0,028$ & 0,833 & $-0,061$ & 0,644 \\
\hline 9 & DD & 0,000 & 0,997 & $-0,148$ & 0,258 & $-0,259$ & 0,046 \\
\hline 10 & $\mathrm{CI}$ & $-0,115$ & 0,382 & 0,251 & 0,053 & 0,070 & 0,598 \\
\hline 11 & $\mathrm{CP}$ & 0,374 & 0,003 & $-0,210$ & 0,107 & $-0,105$ & 0,423 \\
\hline 12 & $\mathrm{DC}$ & 0,347 & 0,007 & $-0,162$ & 0,216 & $-0,146$ & 0,267 \\
\hline 13 & $\mathrm{UC}$ & 0,302 & 0,019 & 0,263 & 0,043 & 0,099 & 0,450 \\
\hline 14 & UP & 0,051 & 0,697 & $-0,447$ & 0,000 & $-0,260$ & 0,045 \\
\hline 15 & UE & $-0,241$ & 0,064 & $-0,015$ & 0,913 & 0,203 & 0,121 \\
\hline 16 & UM & $-0,325$ & 0,011 & 0,208 & 0,110 & 0,037 & 0,778 \\
\hline 17 & UF & $-0,265$ & 0,041 & $-0,128$ & 0,331 & 0,037 & 0,780 \\
\hline 18 & UA & 0,072 & 0,584 & 0,203 & 0,120 & 0,201 & 0,124 \\
\hline 19 & UR & $-0,020$ & 0,879 & $-0,180$ & 0,168 & $-0,329$ & 0,010 \\
\hline 20 & UV & 0,124 & 0,344 & 0,150 & 0,252 & 0,137 & 0,296 \\
\hline 21 & UU & 0,012 & 0,928 & 0,126 & 0,337 & 0,173 & 0,185 \\
\hline 22 & $\mathrm{AJ}$ & $-0,438$ & 0,000 & 0,069 & 0,598 & 0,057 & 0,665 \\
\hline 23 & $\mathrm{AM}$ & $-0,513$ & 0,000 & $-0,247$ & 0,057 & $-0,006$ & 0,965 \\
\hline 24 & $\mathrm{AT}$ & 0,403 & 0,001 & 0,142 & 0,280 & $-0,163$ & 0,215 \\
\hline 25 & $\mathrm{NN}$ & 0,126 & 0,337 & $-0,023$ & 0,862 & 0,210 & 0,108 \\
\hline 26 & NI & $-0,180$ & 0,301 & 0,007 & 0,970 & 0,154 & 0,376 \\
\hline 27 & $\mathrm{PT}$ & 0,014 & 0,918 & 0,121 & 0,359 & $-0,097$ & 0,461 \\
\hline 28 & KA & 0,432 & 0,001 & $-0,002$ & 0,987 & $-0,206$ & 0,114 \\
\hline 29 & $\mathrm{CA}$ & 0,437 & 0,000 & 0,058 & 0,663 & $-0,147$ & 0,263 \\
\hline 30 & MG & 0,310 & 0,016 & 0,020 & 0,878 & $-0,070$ & 0,595 \\
\hline 31 & SE & $-0,208$ & 0,112 & 0,086 & 0,516 & $-0,119$ & 0,365 \\
\hline 32 & $\mathrm{AZ}$ & $-0,023$ & 0,860 & $-0,157$ & 0,231 & 0,203 & 0,119 \\
\hline 33 & DU & 0,373 & 0,003 & 0,037 & 0,780 & $-0,106$ & 0,422 \\
\hline 34 & $\mathrm{CO}$ & 0,167 & 0,202 & $-0,011$ & 0,936 & 0,184 & 0,159 \\
\hline 35 & $\mathrm{CR}$ & $-0,046$ & 0,727 & $-0,035$ & 0,791 & $-0,070$ & 0,594 \\
\hline
\end{tabular}


Anexo L.1. Valores das correlações $(r)$ das variáveis descritivas do ambiente tomadas nas estações chuvosas com as dimensões utilizadas na técnica de NMDS. Tamanho da amostra: 60. Os valores em negrito indicam correlações significantes ao nível de $0,05(p<0,05)$

\begin{tabular}{|c|c|c|c|c|c|c|c|}
\hline \multirow[b]{2}{*}{ \# } & \multirow[b]{2}{*}{ cód } & \multicolumn{2}{|c|}{ Dimensão 1} & \multicolumn{2}{|c|}{ Dimensão 2} & \multicolumn{2}{|c|}{ Dimensão 3} \\
\hline & & $r$ & $p$ & $r$ & $p$ & r & $p$ \\
\hline 36 & $\mathrm{TU}$ & $-0,043$ & 0,745 & 0,047 & 0,721 & $-0,121$ & 0,355 \\
\hline 37 & $\mathrm{CN}$ & 0,423 & 0,001 & 0,046 & 0,729 & $-0,056$ & 0,669 \\
\hline 38 & $\mathrm{PH}$ & 0,326 & 0,011 & 0,044 & 0,736 & $-0,129$ & 0,327 \\
\hline 39 & OD & $-0,261$ & 0,044 & 0,059 & 0,657 & $-0,306$ & 0,017 \\
\hline 40 & SA & $-0,316$ & 0,124 & 0,219 & 0,294 & $-0,348$ & 0,088 \\
\hline 41 & TG & 0,036 & 0,782 & 0,015 & 0,907 & 0,046 & 0,725 \\
\hline 42 & SI & $-0,218$ & 0,094 & 0,034 & 0,800 & 0,143 & 0,276 \\
\hline 43 & LP & 0,448 & 0,000 & $-0,164$ & 0,211 & $-0,125$ & 0,343 \\
\hline 44 & AP & $-0,217$ & 0,096 & 0,217 & 0,096 & 0,181 & 0,167 \\
\hline 45 & SO & $-0,320$ & 0,013 & 0,219 & 0,093 & 0,167 & 0,202 \\
\hline 46 & IS & 0,331 & 0,052 & $-0,178$ & 0,306 & $-0,148$ & 0,395 \\
\hline 47 & NU & 0,105 & 0,427 & 0,108 & 0,414 & 0,067 & 0,611 \\
\hline 48 & $\mathrm{PC}$ & 0,173 & 0,187 & $-0,070$ & 0,595 & 0,221 & 0,091 \\
\hline 49 & $\mathrm{RP}$ & 0,379 & 0,003 & $-0,123$ & 0,350 & 0,171 & 0,192 \\
\hline 50 & QT & $-0,081$ & 0,538 & 0,365 & 0,004 & $-0,048$ & 0,718 \\
\hline 51 & VE & $-0,005$ & 0,968 & 0,174 & 0,185 & $-0,081$ & 0,536 \\
\hline 52 & $\mathrm{PF}$ & 0,286 & 0,027 & 0,057 & 0,668 & $-0,173$ & 0,187 \\
\hline 53 & UB & $-0,138$ & 0,294 & $-0,012$ & 0,931 & 0,229 & 0,078 \\
\hline 54 & VM & 0,232 & 0,074 & 0,066 & 0,616 & $-0,020$ & 0,881 \\
\hline 55 & LM & 0,007 & 0,959 & $-0,102$ & 0,440 & $-0,233$ & 0,073 \\
\hline 56 & PM & 0,511 & 0,000 & $-0,371$ & 0,004 & 0,177 & 0,177 \\
\hline 57 & PX & 0,425 & 0,001 & $-0,401$ & 0,001 & $-0,074$ & 0,576 \\
\hline 58 & VP & 0,378 & 0,003 & $-0,239$ & 0,066 & $-0,084$ & 0,523 \\
\hline 59 & $\mathrm{AC}$ & 0,007 & 0,959 & $-0,102$ & 0,440 & $-0,233$ & 0,073 \\
\hline 60 & $\mathrm{VC}$ & 0,433 & 0,001 & $-0,440$ & 0,000 & 0,013 & 0,919 \\
\hline 61 & DS & 0,199 & 0,131 & 0,043 & 0,747 & 0,237 & 0,070 \\
\hline 62 & $\mathrm{PA}$ & $-0,175$ & 0,181 & 0,011 & 0,933 & $-0,365$ & 0,004 \\
\hline 63 & MV & $-0,540$ & 0,000 & $-0,066$ & 0,618 & $-0,031$ & 0,817 \\
\hline 64 & VV & 0,029 & 0,829 & $-0,094$ & 0,476 & 0,224 & 0,085 \\
\hline 65 & PU & $-0,170$ & 0,195 & 0,031 & 0,817 & 0,254 & 0,050 \\
\hline
\end{tabular}


Anexo L.2. Valores das correlações ( $r$ ) das variáveis descritivas do ambiente tomadas nas estações secas com as dimensões utilizadas na técnica de NMDS. Tamanho da amostra: 58. Os valores em negrito indicam correlações significantes ao nível de $0,05(p<0,05)$. Não puderam ser computadas as correlações com as variáveis SA e IS

\begin{tabular}{|c|c|c|c|c|c|c|c|}
\hline \multirow[b]{2}{*}{ \# } & \multirow[b]{2}{*}{ cód } & \multicolumn{2}{|c|}{ Dimensão 1} & \multicolumn{2}{|c|}{ Dimensão 2} & \multicolumn{2}{|c|}{ Dimensão 3} \\
\hline & & $r$ & $p$ & $r$ & $p$ & $r$ & $p$ \\
\hline 1 & HS & $-0,197$ & 0,139 & 0,315 & 0,016 & 0,201 & 0,130 \\
\hline 2 & SH & $-0,125$ & 0,352 & 0,157 & 0,240 & 0,027 & 0,838 \\
\hline 3 & DL & 0,034 & 0,799 & 0,098 & 0,464 & $-0,265$ & 0,044 \\
\hline 4 & $\mathrm{DE}$ & $-0,340$ & 0,009 & 0,008 & 0,950 & $-0,010$ & 0,942 \\
\hline 5 & DQ & $-0,135$ & 0,313 & $-0,056$ & 0,677 & 0,015 & 0,913 \\
\hline 6 & EL & $-0,515$ & 0,000 & 0,022 & 0,871 & 0,183 & 0,169 \\
\hline 7 & EM & $-0,578$ & 0,000 & $-0,006$ & 0,963 & 0,232 & 0,080 \\
\hline 8 & DG & $-0,308$ & 0,019 & 0,145 & 0,277 & 0,035 & 0,792 \\
\hline 9 & DD & $-0,019$ & 0,886 & 0,363 & 0,005 & 0,003 & 0,982 \\
\hline 10 & $\mathrm{CI}$ & $-0,127$ & 0,342 & $-0,225$ & 0,089 & $-0,147$ & 0,269 \\
\hline 11 & $\mathrm{CP}$ & 0,410 & 0,001 & 0,177 & 0,185 & 0,028 & 0,834 \\
\hline 12 & DC & 0,361 & 0,005 & 0,234 & 0,077 & 0,012 & 0,927 \\
\hline 13 & $\mathrm{UC}$ & 0,206 & 0,121 & $-0,309$ & 0,018 & $-0,368$ & 0,005 \\
\hline 14 & UP & 0,137 & 0,307 & 0,458 & 0,000 & 0,371 & 0,004 \\
\hline 15 & UE & $-0,217$ & 0,103 & $-0,208$ & 0,118 & 0,081 & 0,546 \\
\hline 16 & UM & $-0,304$ & 0,020 & $-0,019$ & 0,888 & 0,013 & 0,924 \\
\hline 17 & UF & $-0,244$ & 0,065 & 0,070 & 0,600 & 0,144 & 0,282 \\
\hline 18 & UA & 0,068 & 0,613 & $-0,168$ & 0,207 & $-0,168$ & 0,207 \\
\hline 19 & UR & $-0,052$ & 0,700 & 0,423 & 0,001 & $-0,005$ & 0,972 \\
\hline 20 & UV & 0,145 & 0,278 & $-0,033$ & 0,809 & $-0,152$ & 0,256 \\
\hline 21 & UU & $-0,006$ & 0,964 & $-0,229$ & 0,084 & $-0,017$ & 0,899 \\
\hline 22 & $\mathrm{AJ}$ & $-0,467$ & 0,000 & 0,103 & 0,440 & 0,072 & 0,593 \\
\hline 23 & $\mathrm{AM}$ & $-0,456$ & 0,000 & 0,193 & 0,147 & 0,314 & 0,017 \\
\hline 24 & AT & 0,400 & 0,002 & 0,178 & 0,182 & $-0,242$ & 0,067 \\
\hline 25 & $\mathrm{NN}$ & 0,267 & 0,043 & 0,004 & 0,979 & 0,080 & 0,549 \\
\hline 26 & NI & $-0,255$ & 0,107 & $-0,093$ & 0,562 & $-0,084$ & 0,603 \\
\hline 27 & PT & 0,161 & 0,228 & $-0,085$ & 0,527 & 0,236 & 0,075 \\
\hline 28 & KA & 0,310 & 0,018 & 0,364 & 0,005 & $-0,008$ & 0,954 \\
\hline 29 & $\mathrm{CA}$ & 0,379 & 0,003 & 0,178 & 0,181 & $-0,211$ & 0,112 \\
\hline 30 & MG & $\mathbf{0 , 3 0 7}$ & 0,019 & 0,147 & 0,271 & $-0,153$ & 0,253 \\
\hline 31 & $\mathrm{SE}$ & $-0,202$ & 0,128 & 0,059 & 0,662 & $-0,094$ & 0,481 \\
\hline 32 & $\mathrm{AZ}$ & 0,326 & 0,013 & 0,033 & 0,805 & 0,130 & 0,330 \\
\hline 33 & DU & 0,349 & 0,007 & 0,164 & 0,218 & $-0,185$ & 0,165 \\
\hline 34 & $\mathrm{CO}$ & 0,327 & 0,012 & $-0,010$ & 0,940 & $-0,009$ & 0,947 \\
\hline 35 & $\mathrm{CR}$ & 0,157 & 0,240 & $-0,095$ & 0,479 & $-0,029$ & 0,826 \\
\hline
\end{tabular}


Anexo L.2. Valores das correlações $(r)$ das variáveis descritivas do ambiente tomadas nas estações secas com as dimensões utilizadas na técnica de NMDS. Tamanho da amostra: 58. Os valores em negrito indicam correlações significantes ao nível de $0,05(p<0,05)$. Não puderam ser computadas as correlações com as variáveis SA e IS

\begin{tabular}{|c|c|c|c|c|c|c|c|}
\hline \multirow[b]{2}{*}{ \# } & \multirow[b]{2}{*}{ cód } & \multicolumn{2}{|c|}{ Dimensão 1} & \multicolumn{2}{|c|}{ Dimensão 2} & \multicolumn{2}{|c|}{ Dimensão 3} \\
\hline & & $r$ & $p$ & $r$ & $p$ & $r$ & $p$ \\
\hline 36 & $\mathrm{TU}$ & 0,034 & 0,799 & $-0,135$ & 0,314 & $-0,119$ & 0,375 \\
\hline 37 & $\mathrm{CN}$ & 0,355 & 0,006 & 0,172 & 0,196 & $-0,200$ & 0,133 \\
\hline 38 & $\mathrm{PH}$ & 0,277 & 0,035 & 0,077 & 0,568 & 0,057 & 0,669 \\
\hline 39 & OD & $-0,337$ & 0,010 & $-0,312$ & 0,017 & 0,127 & 0,340 \\
\hline 40 & TG & $-0,024$ & 0,861 & 0,231 & 0,081 & 0,336 & 0,010 \\
\hline 41 & SI & $-0,047$ & 0,727 & 0,036 & 0,787 & $-0,012$ & 0,928 \\
\hline 42 & LP & 0,045 & 0,736 & 0,185 & 0,165 & $-0,069$ & 0,610 \\
\hline 43 & AP & $-0,404$ & 0,002 & $-0,067$ & 0,619 & $-0,116$ & 0,390 \\
\hline 44 & SO & $-0,291$ & 0,028 & $-0,148$ & 0,274 & $-0,306$ & 0,021 \\
\hline 45 & NU & 0,175 & 0,193 & $-0,106$ & 0,434 & $-0,145$ & 0,281 \\
\hline 46 & $\mathrm{PC}$ & 0,378 & 0,004 & 0,133 & 0,326 & $-0,159$ & 0,239 \\
\hline 47 & $\mathrm{RP}$ & 0,580 & 0,000 & 0,164 & 0,222 & 0,074 & 0,582 \\
\hline 48 & QT & $-0,228$ & 0,088 & $-0,069$ & 0,612 & $-0,324$ & 0,014 \\
\hline 49 & VE & 0,492 & 0,000 & 0,278 & 0,037 & 0,109 & 0,421 \\
\hline 50 & $\mathrm{PF}$ & 0,269 & 0,043 & 0,103 & 0,444 & 0,114 & 0,399 \\
\hline 51 & UB & $-0,197$ & 0,141 & $-0,094$ & 0,488 & $-0,065$ & 0,630 \\
\hline 52 & VM & $-0,636$ & 0,000 & $-0,158$ & 0,240 & 0,227 & 0,090 \\
\hline 53 & LM & $-0,098$ & 0,471 & 0,051 & 0,708 & 0,244 & 0,068 \\
\hline 54 & $\mathrm{PM}$ & 0,506 & 0,000 & 0,157 & 0,243 & 0,114 & 0,399 \\
\hline 55 & PX & 0,428 & 0,001 & 0,090 & 0,511 & 0,204 & 0,131 \\
\hline 56 & VP & 0,490 & 0,000 & 0,229 & 0,087 & 0,150 & 0,267 \\
\hline 57 & $\mathrm{AC}$ & $-0,098$ & 0,471 & 0,051 & 0,708 & 0,244 & 0,068 \\
\hline 58 & $\mathrm{VC}$ & 0,392 & 0,003 & 0,208 & 0,120 & 0,264 & 0,047 \\
\hline 59 & DS & $-0,042$ & 0,757 & 0,028 & 0,835 & $-0,005$ & 0,972 \\
\hline 60 & PA & $-0,272$ & 0,041 & 0,015 & 0,911 & 0,099 & 0,463 \\
\hline 61 & MV & $-0,599$ & 0,000 & $-0,195$ & 0,145 & 0,039 & 0,776 \\
\hline 62 & VV & $-0,369$ & 0,005 & $-0,027$ & 0,843 & 0,304 & 0,021 \\
\hline 63 & PU & $-0,041$ & 0,761 & 0,101 & 0,457 & $-0,034$ & 0,799 \\
\hline
\end{tabular}




\section{REFERÊNCIAS BIBLIOGRÁFICAS}

ALLAN, J.D. Stream Ecology. London: Chapman \& Hall, 1996. 388 p.

AMERICAN PUBLIC HEALTH ASSOCIATION Standard Methods for the examinations of water and wastewater. Washington: American Public Health Association, 1975. $1193 \mathrm{p}$.

ANGERMEIER, P.L.; KARR, J.R. Fish communities along environmental gradients in a system of tropical streams. Environmental Biology of Fishes, v.9, p.117-135, 1983.

ANGERMEIER, P.L.; WINSTON, M.R. Local vs. regional influences on local diversity in stream fish communities of Virginia. Ecology, v.79, n.3, p.911-927, 1998.

ARGENT, D.G.; BISHOP, J.A.; STAUFFER, J.R.; CARLINE, R.F.; MYERS, W.L. Predicting freshwater fish distributions using landscape-level variables. Fisheries Research, v.60, n.2003, p.17-32, 2003.

ARMANTROUT, N.B. Aquatic habitat inventories using remote sensing. Ecohydrology \& Hydrobiology, v.1, n.1/2, p.117-132, 2001.

BARTHEM, R.; GOULDING, M. Os bagres balizadores: ecologia, migração, e conservação de peixes amazônicos. Brasília: Sociedade Civil Mamirauá, 1997. 129 p.

BARTON, D.R.; TAYLOR, W.D.; BIETTE, R.M. Dimensions of riparian buffer strips required to maintain trout habitat in southern Ontario streams. North American Journal of Fisheries Management, v.5, p.364-378, 1985.

BERKMAN, H.E.; RABENI, C.F. Effects of siltation on stream fish communities. Environmental Biology of Fishes, v.18, n.4, p.285-294, 1987.

BESCHTA, R.L. Long-pattern of sediment production following road constructions and logging in the Oregon coast range. Water Resources Research, v.14, p.1011-1016, 1978. 
BILBY, R.E.; BISSON, P.A. Allochthonous versus autochthonous organic matter contributions to the trophic support of fish populations in clear-cut and old-growth forested streams. Canadian Journal of Fisheries and Aquatic Resources, v.49, p.540-551, 1992.

BISSON, P.A.; MONTGOMERY, D.R. Valley segments, stream reaches, and channel units. In: HAUER, R.; LAMBERTI, G.A. (Ed.). Methods in stream ecology. San Diego: Academic Press, 1996. p.23-52.

BISSON, P.A.; QUINN, T.P.; REEVES, G.H.; GREGORY, S.V. Best management practices, cumulative effects, and long-term trends in fish abundance in Pacific Northwest river systems. In: Naiman, R.J. (Ed.). Watershed management: balancing sustainability and environmental change. New York: Springer, 1992. p.189-233.

BRETSCHKO, G. River / land ecotones: scales and patterns. Hydrobiologia, v.303, p.83-91, 1995.

BROWN, L.R. Fish communities and their associations with environmental variables, lower San Joaquin River drainage, California. Environmental Biology of Fishes, v.57, p.251-269, 2000.

BURCHAM, J. Fish communities and environmental characteristics of two lowland streams in Costa Rica. Revista de Biologia Tropical, v.36, n.2A, p.273-285, 1988.

CASATTI, L.; CASTRO, R.M.C. Fish community of the São Franscisco River headwaters riffles, southeastern Brazil. Ichthyological Explorations of Freshwaters, v.9, n.3, p.229-242, 1998.

CASATTI, L.; LANGEANI, F.; CASTRO, R.M.C. Peixes de riacho do Parque Estadual Morro do Diabo, bacia do Alto Rio Paraná, SP. Biota Neotropica, v.1, n.1, p.1-15, 2001.

CASTRO, R.; CASATTI, L. The fish fauna from a small forest stream of the upper Paraná River basin, southeastern Brazil. Ichthyological Explorations of Freshwaters, v.7, p.337-352, 1997.

CASTRO, R.M.C.; CASATTI, L.; SANTOS, H.F.K.; FERREIRA, M.; RIBEIRO, A.C.; BENINE, R.C.; DARDIS, G.Z.P.; MELO, A.L.A.; STOPIGLIA, R.; ABREU, T.X.; BOCKMANN, F.A.; CARVALHO, M.; GIBRAN, F.Z.; LIMA, F.C.T. Estrutura e composição da ictiofauna de riachos do rio Paranapanema, sudeste e sul do Brasil. Biota Neotropica, v.3, n.1, p.1-31, 2003.

CAVAlli, A.C.; PECHE FILHO, A.; LOMBARDI NETO, F.; MORAES, J.F.L. Fragilidade das terras da bacia do rio Corumbataí ao uso de diferentes métodos para o preparo do solo. Acta Scientiarum, v.23,n.5, p.1077-1084, 2001. 
CAUGHLEY G.; SINCLAIR A.R.E. Wildlife ecology and management. Cambridge: Blackwell Scientific, 1994. 334p.

CEAPLA. Atlas Ambiental da Bacia do Rio Corumbataí. Disponível no endereço: http://ns.rc.unesp.br/igce/ceapla/atlas/ (17 jan. 2005).

CETRA, M. Caracterização das assembléias de peixes da Bacia do Rio Corumbataí, SP. São Carlos, 2003. 88p. Tese (Doutorado) - Escola de Engenharia de São Carlos, Universidade de São Paulo.

CHRISTOFOlETTI, A. Geomorfologia Fluvial. São Paulo: Edgard Blücher, 1981. $188 \mathrm{p}$.

COLWELL, R.K. EstimateS: Statistical estimation of species richness and shared species from samples. Version 7.00. 2004. Disponível em http://viceroy.eeb.uconn.edu/estimates (18 jan. 2005)

COSTA, W.J.E.M. Feeding habitats of a fish community in a tropical coastal stream, Rio Mato Grosso, Brazil. Studies on Neotropical Fauna and Environment, v.22, n.3, p.145-153, 1987.

CROSS, F.P.; MOSS, R.E. Historic changes in fish communities and aquatic habitats in plains streams of Kansas. In: MATTHEWS, W.J.; HEINS, D.C. (Ed.). Community and evolutionary ecology of north American stream fishes. Norman: University of Oklahoma Press, 1987. p.155-165.

CUMMINS, K.H. An evaluation of some techniques for the collection and analysis of benthic samples with special emphasis on lotic waters. American Midland Naturalist, v.67, n.2, p.477-504, 1962.

DAHLSTRÖM, N.; NILSSON, C. Influence of woody debris on channel structure in old growth and managed forest streams in Central Sweden. Environmental Management, v.33, n.3, p.376-384, 2004.

DEAN, W. Rio Claro, um sistema brasileiro de grande lavoura, 1820-1920. Rio de Janeiro: Paz e Terra, 1977. 205p.

DUFECH, A.P.S; AZEVEDO, M.A.; FIALHO, C.B. Comparative dietary analysis of two populations of Mimagoniates reocharis (Characidae: Glandulocaudinae) from two streams of Southeastern Brazil. Neotropical Ichthyology, v.1, n.1, p. 67-74, 2003.

DUNNING, J.B., DANIELSON, B.J.; PULLIAM, H.R. Ecological processes that affect population in complex landscapes. Oikos, v.65, n.1, p.169-175, 1992. 
EDWARDS, E.D.; HURYN, A.D. Effect of riparian land use on contributions invertebrates to streams. Hydrobiologia, v.337, n.1/3, p.151-159, 1996.

ESTEVES, K.E.; LOBÓN-CERVIÁ, J. Composition and trophic structure of a fish community of a clearwater Atlantic rainforest stream in southeastern Brazil. Environmental Biology of Fishes, v.62, p.429-440, 2001.

FARIA, A.P.; MARQUES, J.S. O desaparecimento de pequenos rios brasileiros. Ciência Hoje, v.25, n.146, 57-61, 1999.

FAUSCH, K.D.; TORGERSEN, C.E.; BAXTER, C.V.; LI, H.W. Landscapes to riverscapes: bridging the gap between research and conservation of stream fishes. BioScience, v.52, n.6, p.483-498, 2002.

FERRAZ, K.M.P. Distribuição espacial da capivara (Hydrochaeris hydrochaeris) em função da paisagem na bacia do rio Piracicaba, SP. Piracicaba, 2004. 115p. Tese (Doutorado) - Escola Superior de Agricultura "Luiz de Queiroz", Universidade de São Paulo.

FERRAZ, S.F.B. Dinâmica da paisagem na região central de Rondônia e seus efeitos na composição química da água. Piracicaba, 2004. Tese (Doutorado) - Escola Superior de Agricultura "Luiz de Queiroz", Universidade de São Paulo.

FERREIRA, A. Ecologia trófica de Astyanax paranae (Osteichthyes, Characidae) em córregos da bacia do rio Passa-Cinco, Estado de São Paulo. Piracicaba, 2004. 56p. Dissertação (Mestrado) - Escola Superior de Agricultura "Luiz de Queiroz", Universidade de São Paulo.

FITZGERALD, D.G.; KOTT, E.; LANNO, R.P.; DIXON, D.G. A quarter century of change in the fish communities of three small streams modified by anthropogenic activities. Journal of Aquatic Stress and Recovery, v.6, p.111-127, 1998.

FITZPATRICK, F.A.; WAITE, I.R.; D'ARCONTE, P.J.; MEADOR, M.R.; MAUPIN, M.A.; GURTZ, M.E. Revised methods for characterization of stream habitat in the national-quality assessment program. Raleigh: U.S. Geological Survey, Waterresources Investigations Report, 98-4052, 1998. 77p.

FORMAN, R.T.T.; GODRON, M. Landscape ecology. New York: John Wiley, 1986. $619 \mathrm{p}$.

FORMAN, R.T.T. Land mosaics, the ecology of landscapes and regions. Cambridge: Cambridge University Press, 1995. 632p.

FRISSEL, A.C.; LISS, W.J.; WARREN, C.E.; HURLEY, M.D. A hierarchical framework for stream habitat classification: viewing streams in a watershed context. Environmental Management, v.10, n.2, p.199-214, 1986. 
FROESE, R.; PAULY, D. (Ed.). FishBase. World Wide Web Electronic Publication, 2004. www.fishbase.org. (17 jan. 2005).

GERHARD, P.; MORAES, R.; MOLLANDER, S. Stream fish communities and their associations to habitat variables in a rain forest reserve in southeastern Brazil. Environmental Biology of Fishes, v.71, n.4, p.321-340, 2004.

GERKING, S. D. Feeding ecology of fish. San Diego: Academic Press, 1994. 416p.

GORMAN, O.T.; KARR, J.R. Habitat structure and stream fish communities. Ecology, v.59, p.507-515, 1978.

GOULDING, M. The fishes and the forest: explorations in amazonian natural history. Los Angeles: University of California Press, 1980. 280p.

GREGORY, S.V.; SWANSON, F.J.; McKEE, W.A.; CUMMINS, K.W. An ecosystem perspective of riparian zones. BioScience, v.41, n.8, p.540-551, 1991.

GRIFFITH, J.A. Geographic techniques and recent applications of remote sensing to landscape-water quality studies. Water, Air and Soil Pollution, v.138, p.181-197, 2002.

HARDING, J.S.; BENFIELD, E.F.; BOLSTAD, P.V.; HELFMAN, G.S.; JONES III, B.D. Stream biodiversity: the ghost of land use past. Proceedings of the National Academy of Sciences, v.95, p.14843-14847, 1998.

HAWKINS, C.P.; KERSHNER, J.L.; BISSON, P.A.; BRYANT, M.D.; DECKER, L.M.; GREGORY, S.V.; McCULLOUGH, D.A.; OVERTON, C.K.; REEVES, G.H.; STEEDMAN, R.J.; YOUNG, M.K. A hierarchical approach to classifying stream habitat features. Fisheries, v.18, n.6, p.3-19, 1993.

HILDREW, A.G.; GILLER, P.S. Patchiness, species interactions and disturbance in the stream benthos. In: GILLER, P.S.; HILDREW, A.G.; RAFFAELLI, D.G. (Ed.). Aquatic ecology, scale, pattern and process. Oxford: Blackwell Science, 1995. p.21-61.

HILL, J.; GROSSMAN, G.D. Home range estimates for three north American stream fishes. Copeia, v.2, p.376-380, 1987.

HYAMS, D. Curve Expert 1.38, a curve fitting system for Windows. 2001. Disponível em http://curveexpert.webhop.biz/ (18 jan. 2005)

HUECK, K. As florestas da América do Sul. São Paulo: Polígono, 1972. 466p.

HYNES, H.B.N. The ecology of running waters. Liverpool: Liverpool University Press, 1972. 555p. 
HYNES, H.B.N. The stream and its valley. Verhandlugen der Internationalen Vereinigung für Theoretische und Angewandte Limnologie, v.19, p.1-15, 1975.

IMHOF, J.G.; FITZGIBBON, J.; ANNABLE, W.K. A hierarchical evaluation system for characterizing watershed ecosystems for fish habitat. Canadian Journal of Fisheries and Aquatic Sciences, v.53, p.312-326, 1996. Supplement, 1.

INSTITUTO DE PESQUISAS TECNOLÓGICAS. Mapa geomorfológico do Estado de São Paulo (Elaborado por Waldir Lopes Ponçano e Celso Dal Re Carneiro). São Paulo, 1981.91p.

JOHNSON, S.L.; COVICH, A.P. Scales of observation of riparian forests and distributions of suspended detritus in a prairie river. Freshwater Biology, v.37, p.163-175, 1997.

JONES, E.B.D. III; HELFMAN, G.S.; HARPER, J.O.; BOLSTAD, P.V. Effects of riparian forest removal on fish assemblages in southern appalachian streams. Conservation Biology, v.13, n.6, p.1-12, 1999.

KARR, J.R.; CHU, E.W. Restoring life in running waters: better biological monitoring. Washington: Island Press, 1999. 206p.

KARR, J.R.; SCHLOSSER, I.J. Impact of nearstream vegetation and stream morphology on water quality and stream biota. Athens: Environmental Protection Agency, 1977. 91 p. (Report Series)

KARR, J.R.; SCHLOSSER, I.J. Water resources and the land-water interface. Science, v.201, p.229-234, 1978.

KARR, J.R., Assessment of biological integrity using fish communities. Fisheries, v.6, p.21-27, 1981.

KLAPPROTH, J.C.; JOHNSON, J.E. Understanding the science behind riparian forest buffers: effects on water quality. Virginia: Cooperative Extension, Publication, 2000. 20p.

KOFFLER, N.F. Uso das terras da bacia do rio Corumbataí em 1990. Geografia, v.18, n.1, p.135-150, 1993.

KOLASA, J.; ZALEWSKI, M. Notes on ecotone attributes and functions. Hydrobiologia, v.303, p.1-7, 1995.

KREBS, C.J. Ecological Methodology. New York: Benjamin / Cummings, 1999. 620 p.

KRUSKAL, J.B.; WISH, M. Multidimensional scaling. Iowa City: Sage, 1978. 93p. 
LEGENDRE, P.; LEGENDRE, L. Numerical Ecology. 2.ed. Amsterdam: Elsevier Scientific, 1998. 853p.

LEOPOLD, L.B.; WOLMAN, M.G.; MILLER, J.P. Fluvial processes in geomorphology. New York: Dover Publications, 1964. 522p.

LONZARICH, D.G.; WARREN, M.L.; LONZARICH, M.R.E. Effects of habitat isolation on the recovery of fish assemblages in experimentally defaunated stream pools in Arkansas. Canadian Journal of Fisheries and Aquatic Sciences, v.55, n.9, p.2141-2149, 1998.

LONZARICH, D.G.; WARREN, M.L.; LONZARICH, M.E. Consequences of pool habitat isolation on stream fishes. In: OUACHITA AND OZARK MOUNTAIN SYMPOSIUM: ECOSYSTEM MANAGEMENT RESEARCH, Ashville, 2004. Southern Research Station Publications, North Carolina, 2004. p.246-252.

LONZARICH, D.G.; LONZARICH, M.E.; WARREN, M.L. Effects of riffle length on the short-term movements of fishes among stream pools. Canadian Journal of Fisheries and Aquatic Sciences, v.57, n.7, p.1508-1514, 2000.

LOTRICH, V.A. Growth, production and community composition of fishes inhabiting a first-, second-, and third- order stream of Eastern Kentucky. Ecological Monographs, v.43, n.3, p.377-397, 1973.

LOWE-MCCONNELL, R.H. Ecological studies in tropical fish communities. Cambridge: Cambridge University Press, 1987. 382p.

LOWRANCE, R.; TODD, R.; FAIL JUNIOR, J.; HENDRICKSON JUNIOR, O.; LEONARD, R.; ASMUSSEN, L. Riparian forests as nutrients filters in agricultural watersheds. BioScience, v.34, n.6, p.374-377, 1984.

MAGURRAN, A.E. Ecological diversity and its measurement. Cambridge: Chapman \& Hall, 1988. 177p.

MALANSON, G.P. Riparian landscapes. Cambridge: Cambridge University Press, 1993. 296p.

MARSH-MATTHEWS, E.; MATTHEWS, W.J. Geographic, terrestrial and aquatic factors: which most influence the structure of stream fish assemblage in the midwestern United States. Ecology of Freshwater Fish, v.9, n.1/2, p.9-21, 2000.

MATTHEWS, W.J. Patterns in freshwater fish ecology. Norwell: Chapman \& Hall, 1998. 756p. 
MATTHEWS, W.J.; HOUGH, D.J.; ROBISON, H.W. Similarities in fish distribution and water quality patterns in streams of Arkansas: congruence of multivariate analysis. Copeia, v.1992, p.296-305, 1992.

MCCLEARY, R.; BAMBRICK, C. Historical changes in Rocky Mountains foothills stream fish communities: evaluating the use of fish abundance and size as ecological indicators. In: FOREST LAND-FISH CONFERENCE II - ECOSYSTEM STEWARDSHIP THROUGH COLLABORATIONS, 2., Edmonton, 2004, Proceedings, Alberta, s.ed. p.181-187.

MCCLEARY, R., SHERBURNE C.; BAMBRICK, C. Long-term effects of riparian harvest on fish habitat in three Rocky Mountain foothills watersheds. In: FOREST LAND-FISH CONFERENCE II - ECOSYSTEM STEWARDSHIP THROUGH COLLABORATIONS, 2., Edmonton, 2004, Proceedings, Alberta, s.ed. p.189-198.

MCCORMICK, F.H.; HUGHES, R.M.; KAUFMANN, P.R.; PECK, P.V.; STODDARD, J.L.; HERLIHY, A.T. Development of an index of biotic integrity for the mid-atlantic highlands region. Transactions of the American Fisheries Society, v.130, p.857-877, 2001.

MEIXLER, M.S. Predicting aquatic biodiversity with geographic information systems. Nova Iorque, 2000. 56p. Dissertação (Mestrado) - Departamento de Recursos Naturais, Universidade de Cornell, Ithaca.

MENEZES, N.A.; CASTRO, R.M.C.; WEITZMAN, S.; WEITZMAN, M.J. Peixes de riacho da floresta atlântica brasileira: um conjunto pouco conhecido e ameaçado de vertebrados. In: SIMPÓSIO DE ECOSSISTEMAS DA COSTA SUL E SUDESTE BRASILEIRA; ESTRUTURA, FUNÇÃO E MANEJO, 2., Águas de Lindóia, 1990, Anais, São Paulo: Academia de Ciências do Estado de São Paulo. p.290-295.

MINNS, C.K. Allometry of home range size in lake and river fishes. Canadian Journal of Fisheries and Aquatic Sciences, v.52, p.1499-1508, 1995.

MONTGOMERY, D.R. Process domains and the river continuum. Journal of the American Water Resources Association, v.35, n.2, p.397-410, 1999.

MONTGOMERY, D.R.; ABBE, T.B; BUFFINGTON, J.M.; PETERSON, N.P.; SCHIMIDT, K.M.; STOCK, J.D. Distribution of bedrock and alluvial in forested mountained drainage basins. Nature, v.381, p.587-588, 1996.

MOYLE, P.B.; WILLIAMS, J.E. Biodiversity loss in temperate zone: decline of native fish fauna of California. Conservation Biology, v.4, n.3, p.275-284, 1990.

MOYLE, P.B. Biodiversity, biomonitoring, and the structure of fish communities. In: LOEB, S.L.; SPACIE, A. (Ed.). Biological monitoring of aquatic systems. Boca Ratón: Lewis Publishers, 1994. p.171-186. 
MURPHY, M.L.; HAWKINS, C.P.; ANDERSON, N.H. Effects of canopy modifications and accumulated sediment on stream communities. Transactions of the American Fisheries Society, v.110, p.469-478, 1981.

NAGASAKA, A.; NAKAMURA, F. The influences of land-use changes on hydrology and riparian environment in a northern japanese landscape. Landscape Ecology, v.14, p.543-556, 1999.

NAIMAN, R.J. (Ed.). Watershed management, balancing sustainability and environmental change. New York: Springer, 1992. 542p.

NAIMAN, R.J.; BEECHIE, T.J.; BENDA, L.E.; BERG, D.R.; BISSON, P.A.; MACDONALD, L.H.; O'CONNOR, M.D.; OLSON, P.L.; STEEL, A. Fundamental elements of ecologically healthy watersheds in the pacific northwest coastal ecoregion. In: NAIMAN, R.J. (Ed.). Watershed management, balancing sustainability and environmental change. New York: Springer, 1992. p.127-188.

NAIMAN, R.J.; BILBY, R.E. (Ed.). River ecology and management: lessons from the Pacific Coastal Ecoregion. New York: Springer-Verlag, 1998. 705p.

OSBORNE, L.L.; WILEY, M.J. Influence of tributary spatial position on the structure of warmwater fish communities. Canadian Journal of Fisheries and Aquatic Sciences, v.48, p.671-681, 1992.

OSBORNE, L.L.; KOVACIC, D.A. Riparian vegetated buffer strips in water-quality restoration and stream management. Freshwater Biology, v.29, p.243-258, 1993.

PERINOTTO, J.A. Geologia da bacia hidrográfica do rio Corumbataí. http://ns.rc.unesp.br/igce/ceapla/atlas/atlas.swf. (17 jan. 2005).

PETTS, G.E.; AMOROS, C. (Ed.). Fluvial Hydrosystems. London: Chapman \& Hall, 1996. 322p.

POFF, N.L.; ALLAN, J.D.; BAIN, M.B.; KARR, J.R.; PRESTEGAARD, J.L.; RICHTER, B.D.; SPARKS, R.E.; STROMBERG, J.C. The natural flow regime. BioScience, v.47, n.11,p.769-784, 1997.

POOLE, G.C. Fluvial landscape ecology: addressing uniqueness within the river discontinuum. Freshwater Biology, v.47, p.641-660, 2002.

PROJETO CORUMBATAÍ. Plano Diretor: Conservação dos recursos hídricos por meio da recuperação e da conservação da cobertura florestal da bacia do rio Corumbataí. Relatório Técnico do IPEF, Piracicaba, 2001. 301p. 
RANDALL, R.G.; KELSON, J.R.M.; MINNS, C.K. Fish production in freshwaters: are rivers more productive than lakes? Canadian Journal of Fisheries and Aquatic Sciences, v.52, p.631-643, 1995.

REID, C.M.; CARL, L.M.; LEAN, J. Influence of riffle characteristics, surficial geology and natural barriers on the distribution of the channel darter, Percina copelandi, in the lake Ontario basin. Environmental Biology of Fishes. /No prelo/

REIS, R.E.; KULLANDER, S.O.; FERRARIS, C.J. The check list of the freshwater fishes of South and Central America. Porto Alegre: EDIPUCRS, 2003. 944p.

RINNE, J.N. The utility of stream habitat and biota for identifying potencial conflicting forest and uses: Montane riparian areas. Forest Ecology and Management, v.3334, n.1/4, p.363-383, 1990.

RODRIGUES, R.R. A vegetação de Piracicaba e municípios de entorno. Circular Técnica IPEF, v.189, p.1-18, 1999.

ROSSETTO, R. A cultura da cana: da degradação à conservação. Visão Agrícola, v.1, p.80-85, 2004.

ROTH, N.E.; ALLAN, J.D.; ERICSON, D.L. Landscape influences on stream biotic integrity assessed at multiple spatial scales. Landscape Ecology, v.11, n.3, p.141156, 1996.

SALATI, E. Análise ambiental sintética e qualidade de água do rio Corumbataí (SP) como subsídio para o planejamento regional integrado da bacia de drenagem do rio Corumbataí. São Carlos, 1996. 198 p. Tese (Doutorado) - Universidade Federal de São Carlos.

SCHLOSSER, I.J. Fish community structure and function along two habitat gradients in a headwater stream. Ecological Monographs, v.52, n.4, p.395-414, 1982.

SCHLOSSER, I.J. Environmental variation, life history attributes, and community structure in stream fishes: implications for environmental management and assessment. Environmental Management, v.14, n.5, p.621-628, 1990.

SCHLOSSER, I.J. Stream fish ecology: a landscape perspective. BioScience, v.41, n.10, p.704-712, 1991.

SCHLOSSER, I.J. Critical landscape attributes that influence fish population dynamics in headwater streams. Hydrobiologia, v.303, p.71-81, 1995.

SCOTT, M.C. Integrating the stream and its valley: land-use change, aquatic habitats, and fish assemblages (North Carolina). Geórgia, 2001. 91p. Tese (Doutorado) Universidade da Georgia. 
SCOTT, M.C.; HELFMAN, G.S.; MCTAMMANY, M.E.; BENFIELD, E.F.; BOLSTAD, P.V. Multiscale influences on physical and chemical stream conditions across blue ridge landscapes. Journal of the American Water Resources Association, v.38, n.5, p.1379-139, 2002.

SCOTT, M.C.; HELFMAN, G.S. Native invasions, homogenization, and the mismeasure of integrity of fish assemblages. Fisheries, v.26, n.11, p.6-15, 2001.

SEBER, G.A.F. The estimation of animal abundance. 2.ed. Auckland: The Blackburn Press, 2002. 654 p.

SEDELL, J.R.; REEVES, G.H.; HAUER, F.R.; STANFORD, J.A.; HAWKINS, C.P. Role of refugia in recovery from disturbances: modern fragmented and disconnected river systems. Environmental Management, v.14, n.5, p.711-724, 1990.

SIMON, T.P.; SOBIECH, S.A.; CERVONE; T.H.; MORLAES, N.E. Historical and present distribution of fish in the Patoka river basin: Pike, Gibson and Dubois counties, Indiana. Proceedings of the Indiana Academy of Sciences, v.104, n.3/4, p.193-206, 1995.

SIMONSON, T.D. Quantifying fish habitat in streams - transect spacing, sample size and a proposed framework. North American Journal of Fisheries Management, v.14, n.3, 607-615, 1994.

SNODGRASS, J.W.; BRYAN, A.L.; LIDE, R.F.; SMITH, G.M. Factors affecting the occurrence and structure of fish assemblages in isolated wetlands of the upper coastal plain, USA. Canadian Journal of Fisheries and Aquatic Sciences, v.53, p.443-454, 1996.

SNYDER, C.D.; YOUNG, J.A.; VILELLA, R.; LEMARIÉ, D.P. Influences of upland and riparian land use patterns on stream biotic integrity. Landscape Ecology, v.18, p.647-664, 2003.

SOKAL, R.R.; ROHLF, F.J. Biometry. New York: W.H. Freeman, 1995. 887p.

SPONSELLER, R.A.; BENFIELD, E.F.; VALETT, H.M. Relationships between land use, spatial scale and stream macroinvertebrate communities. Freshwater Ecology, v.46, p.1409-1424, 2001.

STANFORD, J.A. Landscapes and catchment basins. In: HAUER, R.; LAMBERTI, G.A. (Ed.). Methods in stream ecology. San Diego: Academic Press, 1996. p.322. 
STAUFFER, J.C.; GOLDSTEIN, R.M.; NEWMAN, R.M. Relation of wooded riparian zones and runoff potential to fish community composition in the agricultural streams. Canadian Journal of Fisheries and Aquatic Sciences, v.57, p.307-316, 2000 .

TAYLOR, C.M. Abundance and distribution within a guild of benthic stream fishes: local processes and regional patterns. Freshwater Biology, v.36, p.385-396, 1996.

TIPTON, J.A.; BART, H.L.; PILLER, K.R. Geomorphic disturbance and its impact on darter (Teleostomi: Percidae) distribution and abundance in the Pearl River drainage, Mississippi. Hydrobiologia, n.527, p.49-61, 2004.

TORGERSEN, C.E.; FAUX, R.N.; MCINTOSH, B.A.; POAGE, N.J.; NORTON, D.J. Airborne thermal remote sensing for water temperatures assessment in rivers and streams. Remote sensing of the Environment, v.76, n.2001, p.386-398, 2001.

TRIMBLE, S.W.; MENDEL, A.C. The cow as a geomorphic agent: a critical review. Geomorphology, v.13, p.233-253, 1995.

VADAS, R.L.J.; ORTH, D.J. Habitat use of fish communities in a Virginia stream system. Environmental Biology of Fishes, v.59, p.253-269, 2000.

VALENTE, R.O.A. Análise da estrutura da paisagem na bacia do rio Corumbataí, SP. Piracicaba, 2001. 144p. Dissertação (Mestrado) - Escola Superior de Agricultura "Luiz de Queiroz", Universidade de São Paulo.

VALENTE, R.O.A.; VETTORAZZI, C.A. Análise da estrutura da paisagem na bacia do rio Corumbataí, SP. Scientia Forestalis, v.62, p.114-129, 2002.

VALENTE, R.O.A.; VETTORAZZI, C.A. Mapeamento de uso e cobertura do solo da Bacia do Rio Corumbataí, SP. Circular Técnica do IPEF, n.186, p.1-9, 2003.

VANNOTE, R.L.; MINSHALL, G.W.; CUMMINS, K.W.; SEDELL, J.R.; CUSHING, C.E. The river continuum concept. Canadian Journal of Fisheries and Aquatic Sciences, v.37, p.130-137, 1980.

VICTOR, M.A.M. A devastação florestal. São Paulo: Sociedade Brasileira de Silvicultura, 1975. 48p.

VILELLA, F.S.; BECKER, F.G.; HARTZ, S.M. Diet of Astyanax species (Teleostei, Characidae) in an Atlantic Forest river in southern Brazil. Brazilian Archives of Biology and Technology, v.45, n.2, p.223-232, 2002.

VITOUSEK, P.M. The regulation of element concentrations in mountain streams in the northeastern United States. Ecological Monographs, v.47, p.65-87, 1977. 
WANG, L.; LYONS, J.; KANEHL, P.; GATTI, R. Influences of watershed land use on habitat quality and biotic integrity in Wisconsin streams. Fisheries, v.22,n.6, p.6-12, 1997.

WARD, J.V.; TOCKNER, K. Biodiversity: towards an unifying theme for river ecology. Freshwater Biology, v.46, p.807-819, 2001.

WARD, J.V. The four-dimensional nature of lotic ecosystems. Journal of the North American Benthological Society, v.8, p.2-8, 1989.

WASHINGTON, H.G. Diversity, biotic and similarity indices. Water Research, v.18, n.6, p.653-694, 1982.

WATERS, T.F. Sediment in streams. American Fisheries Society Monographs, v.7, p.79-118, 1995.

WIENS, J.A. Riverine landscapes: taking landscape into the water. Freshwater Biology, v.47, p.501-515, 2002.

ZAR, J.H. Biostatistical analysis. Prentice Hall: Upper Saddle River, 1999. 663p.

ZAVATINI, J.A.; CANO, H. Variações do ritmo pluvial na bacia do rio Corumbataí SP. Boletim de Geografia Teorética, v.32, p.215-240, 1993.

ZORN, T.G.; SEELBACH, P.W.; WILEY, M.J. Distributions of stream fishes and their relationship to stream size and hydrology in Michigan's Lower Peninsula. Transactions of the American Fisheries Society, v.131, p.70-85, 2002. 